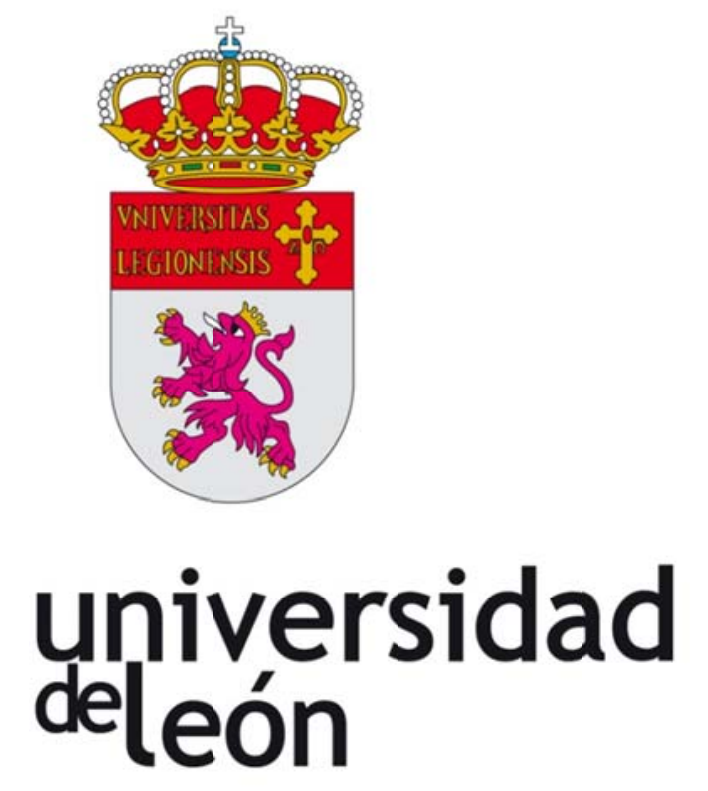

Facultad de Veterinaria

Departamento de Producción Animal

\title{
ESTUDIO DE LA VARIABILIDAD GENÉTICA EN CAMÉLIDOS BOLIVIANOS
}



Las investigaciones de esta Memoria de Tesis Doctoral han sido financiadas por los proyectos A/010497/07 y A/017114/08 del Ministerio de Asuntos Exteriores y Cooperación, Gobierno de España.

La autora de esta Memoria ha sido beneficiaria de una beca de posgrado MAE-AECID de la Agencia de Cooperación Internacional y Desarrollo del Ministerio de Asuntos Exteriores y Cooperación, Gobierno de España (Convocatoria 2008/09 - 0000285871). 

Dedicatoria

A todas las comunidades de criadores de camélidos en el Altiplano boliviano, quienes han inspirado este esfuerzo... 



\section{Agradecimientos}

A todas las personas que de una u otra manera contribuyeron y participaron en la realización de este trabajo. En principio quiero agradecer a mis directores de tesis los doctores Juan José Arranz y Beatriz Gutiérrez-Gil por la confianza depositada en mí para incorporarme en su equipo de investigación, por su enorme apoyo y la paciencia a lo largo de esta prolongada aventura en el estudio de los camélidos sudamericanos. A Volga Iñiguez por la oportunidad brindada para continuar y profundizar el desarrollo de proyectos con comunidades rurales de camélidos en Bolivia y por apoyar desde los primeros pasos a la conclusión de este trabajo.

A la enorme cantidad de gente que ha participado con sugerencias, discusión y apoyo logístico para diseñar el muestreo y toma de datos de este trabajo en Bolivia como la Unidad de Biología Evolutiva del Instituto de Biología Molecular y Biotecnología, Banco Nacional de Germoplasma, Instituto de Lengua y Cultura Aymara y Agencia de Cooperación Sueca. De manera personal quiero agradecer a Tito Rodríguez, Luis Iñiguez, Roberto Chiri, Vladimir Saavedra, Manuel Ruíz, Fernando Romero, Ana María Callisaya y Joely Echalar por su valioso apoyo en esta fase de la tesis.

A todos mis compañeros y personal del Departamento de Producción Animal de la Universidad de León por su grata acogida durante mi larga estancia en España y convertir mis días breves y amenos. A Yolanda Bayón, Araceli Moro, Fernando de la Fuente, Fermín San Primitivo, María García gracias por su gran apoyo emocional.

Un agradecimiento especial a mis compañeras de laboratorio, cafés y conversaciones compartidas. A Marta García, Laura Estebán, Lorena Álvarez, Elsa García, Aroa Suarez, Isabel Maniega y Marina Atlija. Agradecerles por todo el apoyo y gratos momentos compartidos en las largas horas de trabajo de laboratorio y ordenador.

A todos los amigos en España y Bolivia que me apoyaron con palabras de aliento y ánimo en el transcurso de este trabajo. A Francisca Freitas, Carlos Cabezas, Maiara Monteiro, Barry Girgis, Pere Parés, Rosenka Tejerina y Sonia Jiménez, gracias por su confianza.

Finalmente quiero agradecer a toda mi familia, mis padres, hermanos y sobrinos por su apoyo incondicional en todo lo que hago, por saber esperarme y aguantar mis ausencias físicas y mentales. Gracias por su enorme comprensión... 



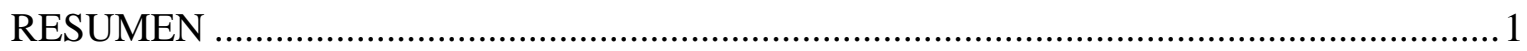

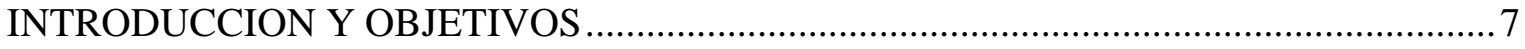

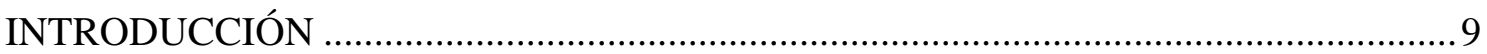

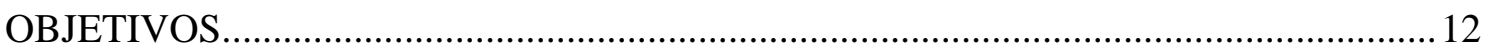

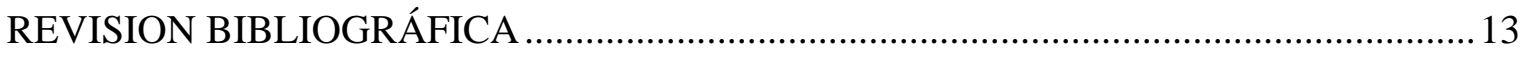

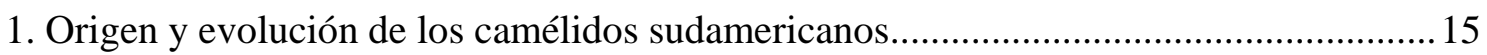

2. Clasificación de los camélidos sudamericanos ............................................................ 17

3. Distribución y hábitat de los camélidos sudamericanos..................................................18

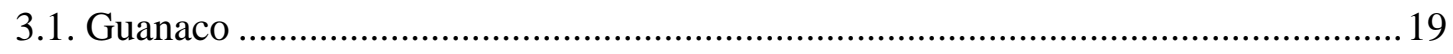

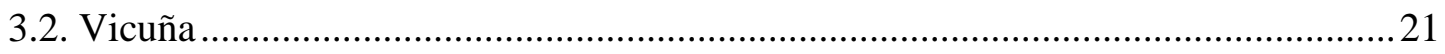

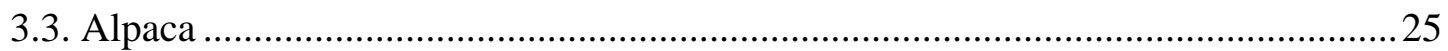

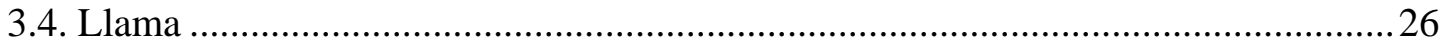

4. Caracterización biológica de los camélidos sudamericanos ...........................................30

5. Procesos de domesticación y situación actual de los camélidos .................................... 33

6. Importancia de los camélidos sudamericanos como recurso animal en Bolivia ..............37

6.1. Sistemas de producción y manejo de los camélidos sudamericanos en el Altiplano

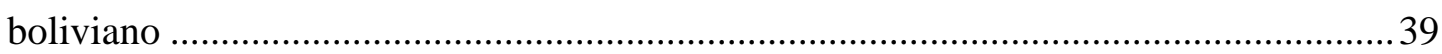

6.1.1. Características de la fibra de los camélidos sudamericanos en Bolivia.............41

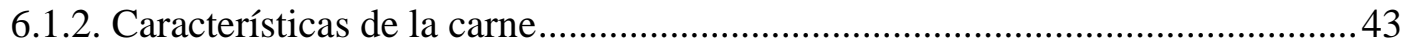

6.1.3. Características de la piel y cuero ...................................................................... 44

7. Aplicación de la genética de poblaciones en el estudio de camélidos sudamericanos ... 45

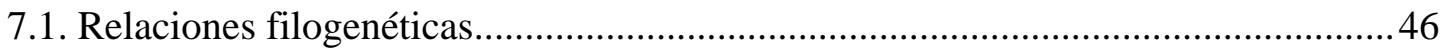

7.2. Resolución de incertidumbres taxonómicas...............................................................4

7.3. Diversidad genética de poblaciones de camélidos sudamericanos ..........................4 47

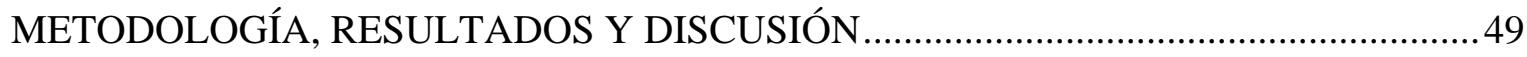


Analysis of genetic diversity in Bolivian llama populations using microsatellites

Genetic diversity and population structure of Bolivian alpacas.

Analysis of mitochondrial DNA in Bolivian llama, alpaca and vicuna populations: a contribution to the phylogeny of the south american camelids.

Mitochondrial DNA (mtDNA) genetic diversity of Vicugna vicugna mensalis in Bolivia.

OBJETIVO 1: Análisis de la diversidad genética de poblaciones de llamas y alpacas bolivianas usando marcadores microsatélites.

OBJETIVO 2: Análisis de la estructura genética de poblaciones de llamas y alpacas bolivianas usando microsatélites.

OBJETIVO 3: Análisis del ADN mitocondrial en poblaciones de llama, alpaca y vicuña en Bolivia: una contribución a la filogenia de los Camélidos Sudamericanos 135

CONCLUSIONES 



\section{RESUMEN}



El estudio de los camélidos sudamericanos es de gran interés en los países andinos como Perú, Bolivia, Chile, Argentina, debido a su importante valor económico y su importancia en el mantenimiento y desarrollo de las poblaciones rurales en dichos países. En Bolivia se encuentra el mayor número de llamas del mundo y la segunda población más grande de alpacas, después de Perú. Este país también alberga al 21 \% de la población mundial de vicuñas criadas en su hábitat natural y un reducido número de guanacos.

Dada la falta de estudios genéticos centrados en las poblaciones de camélidos que habitan en Bolivia, y la necesidad de realizar una valoración de la diversidad genética de estas poblaciones, la presente Tesis doctoral ha abordado el estudio genético de las poblaciones de camélidos en este país, en primer lugar realizando una valoración de la diversidad y estructura genética a nivel del ADN nuclear, de las poblaciones de camélidos domésticos presentes en Bolivia, llamas y alpacas. Estos estudios se basaron en el análisis de marcadores tipo microsatélite en un amplio número de muestras de las especies de camélidos domésticos. En ambos casos, el muestreo de animales se realizó en un amplio rango de distribución geográfica, intentando incluir en el estudio especímenes pertenecientes a las zonas más importantes de explotación de las especies estudiadas.

De forma complementaria, la presente Tesis doctoral presenta un análisis de la diversidad y estructura genética a nivel mitocondrial de las cuatro especies de camélidos sudamericanos. Intentando presentar una imagen lo más completa posible de las relaciones entras las especies domésticas y sus predecesoras salvajes, además de las poblaciones de llamas y alpacas bolivianas analizadas en los estudios nucleares, se estudiaron poblaciones de vicuñas bolivianas y, dado el escaso número de guanacos presentes hoy en día en este país, un grupo de guanacos del sur de Chile. Un análisis adicional con secuencias de ADN mitocondrial (ADNmt) disponible en bases de datos públicas nos permitió realizar un análisis filogenético y valorar el grado de diferenciación entre las poblaciones de camélidos bolivianos y de éstas con otras procedentes de países vecinos, así como detectar un elevado nivel de hibridación en las poblaciones domésticas sobre todo en las poblaciones de alpacas analizadas. De esta forma esta tesis presenta datos genéticos imprescindibles para conocer la historia evolutiva reciente de llamas, alpacas y vicuñas en Bolivia y de guanacos de la Patagonia chilena. 
El análisis de 42 microsatélites en un total de 394 llamas distribuidas en 12 grupos regionales puso de manifiesto altos niveles de diversidad genética determinados por un alto nivel de polimorfismo (alelos identificados: 506; número medio de alelos por marcador: 12.04; heterocigosis esperada promedio por marcador: 0.68) y una débil diferenciación genética entre los grupos regionales analizados (pair-wise $F_{S T}$ rango: 0.003-0.052). De la variabilidad genética total sólo un 1.52 \% fue identificada entre poblaciones. En concordancia con estos resultados, las llamas Bolivianas analizadas mostraron una débil estructura genética, existiendo un intenso flujo genético entre los distintos grupos regionales analizados. Estas observaciones parecen explicarse por el intercambio frecuente de machos reproductores que se lleva a cabo, sin ningún tipo de limitación, entre las distintas poblaciones de cría de llamas en Bolivia. Tan solo los grupos de Sud Lípez y, en menor medida, de Nor Lípez, mostraron un cierto nivel de diferenciación genética probablemente debido al aislamiento geográfico de estas poblaciones del sur del país que presentan limitadas infraestructuras de comunicación.

El estudio de 22 marcadores microsatélites en una población de 149 bolivianas distribuidas en ocho grupos regionales puso de manifiesto la existencia, en la población analizada, de una alta variabilidad genética (alelos identificados: 258; número medio de alelos por marcador: 11; heterocigosis esperada promedio por marcador: 0.74) y una bajamoderada diferenciación genética (pair-wise $\mathrm{F}_{\mathrm{ST}}$ rango: 0.008-0.077). Los coeficientes de consanguinidad fueron positivos y significativamente diferentes de cero para todos los grupos regionales estudiadas excepto Turco. De la variabilidad genética total un 3.86 \% fue identificada entre poblaciones. El análisis de estructura poblacional reveló que los ocho grupos regionales podían agruparse en cinco clusters diferenciados, sugiriendo un aislamiento genético del grupo regional de Poopó y la influencia de Turco sobre las localidades ligadas a los sistemas alpaqueros de Cochabamba y Pacajes-Sajama. Mientras que los animales de Ulla Ulla mostraron una clara subdivisión genética en tres clusters, los de Cosapa, Lagunas y Curahuara mostraron un claro origen genético común.

A pesar de ciertas limitaciones relacionadas con los muestreos realizados, y admitiendo la necesidad de confirmar los resultados aquí presentados con futuros estudios, los resultados descritos en la presente memoria de Tesis doctoral constituyen la primera evaluación de diversidad para las poblaciones de llamas y alpacas bolivianas. Es de esperar 
que los parámetros genéticos aquí aportados puedan servir de referencia para el desarrollo, en Bolivia, de planes de manejo y conservación que afecten a estas dos especies de camélidos sudamericanos.

En cuanto al estudio genético a nivel mitocondrial descrito en esta Tesis doctoral, se analizaron dos fragmentos de ADNmt, la región codificante del citocromo b (Cyt-b; 1200pb) y parte de la región control D-loop (513pb) en un amplio número de muestras que incluyó llamas $(n=109)$, alpacas $(n=36)$ y vicuñas $(n=29)$ bolivianas, así como guanacos $(n=30)$ de Chile. El análisis descrito mostró altos niveles de diversidad genética a nivel mitocondrial y, curiosamente, el Cyt-b resultó ser más variable, por lo general, que la región de D-loop. Las vicuñas mostraron la menor variabilidad genética, seguidas de los guanacos, alpacas y llamas. Los análisis filogenéticos realizados, y que incluyeron secuencias adicionales disponibles en GenBank, confirmaron la existencia de dos clados monofiléticos correspondientes a guanacos $(G)$ y vicuñas $(V)$, mientras que en las especies domésticas, en concordancia con estudios anteriores, se pusieron de manifiesto altos niveles de hibridación, sobre todo en las alpacas.

La presencia de haplotipos de guanacos del sur agrupados con algunas llamas sugirió otros orígenes evolutivos o centros de domesticación para la llama distintos a los hasta ahora aceptados, hipótesis que es apoyada por evidencias arqueozoológicas encontradas en el norte de Chile y Argentina. Además este trabajo permitió la identificación de dos nuevas líneas matrilineales diferentes a los dos clados principales representados por guanacos y vicuñas, lo que sugiere la necesidad de realizar estudios adicionales que incluyan otras poblaciones de camélidos sudamericanos que nos permitan profundizar sobre el origen de las especies domésticas de camélidos sudamericanos. Los resultados descritos en este trabajo aportan, además de una valoración del nivel de diversidad y de hibridación a nivel del ADNmt, una pieza más para el estudio y análisis filogenético del complejo y dinámico proceso de domesticación de los camélidos sudamericanos en Bolivia y su relación con los países vecinos donde también habitan estas especies. 

INTRODUCCION Y OBJETIVOS 



\section{INTRODUCCIÓN}

Los países andinos de América del Sur se constituyen en el hábitat principal de los camélidos sudamericanos. Estos animales se dividen en cuatro especies: guanacos, vicuñas, alpacas y llamas. Las dos primeras son especies silvestres mientras que las otras dos son formas domésticas. La distribución de los camélidos sudamericanos entre los países andinos es muy heterogénea. Así, Bolivia cuenta principalmente con llamas y alpacas ubicadas preferentemente en zonas altas y bofedales. Los camélidos en Perú consisten principalmente de alpacas y una menor proporción de llamas. Existen también grandes manadas de vicuñas salvajes que habitan las zonas altas de Perú y Bolivia. Chile tiene la mayor cantidad de guanacos del mundo situados en la región patagónica y posee llamas y alpacas ubicadas en el norte de la región andina. Además, los guanacos son considerados animales cosmopolitas, ya que viven en tierras altas y tierras bajas.

Estos animales se dedican al aprovechamiento de recursos naturales en zonas extremas donde es difícil establecer explotaciones de animales domésticos. El aprovechamiento de estos recursos se ha hecho imprescindible desde tiempos inmemoriales hasta el presente constituyéndose en el principal medio de utilización productiva de grandes áreas de pastos naturales de las zonas alto-andinas en los países anteriormente mencionados, donde no es posible la agricultura ni la crianza exitosa de otras especies de animales domésticos. Los camélidos tienen la propiedad de convertir con gran eficiencia la vegetación nativa de estos ambientes en carne y fibra de alta calidad, además de contar con pieles y cueros para uso industrial y artesanal. El estiércol es otro subproducto que es utilizado como combustible para la cocción de alimentos y fertilizante. La llama, además, cumple una importante función de transporte en poblaciones aisladas por condiciones geográficas extremas.

La importancia sociológica y económica de los camélidos sudamericanos en los países andinos es muy grande (Iñiguez \& Alem, 1996). Las áreas productoras de camélidos en el Perú incluyen las provincias con mayor pobreza y marginalización, donde se estima que al menos un millón y medio de personas se dedica a la crianza de camélidos. En Bolivia, se estima que la producción de llamas beneficia a 37.000-54.000 
familias de productores de escasos recursos (Vargas, 2005). Sin embargo, este contexto de producción es enormemente complejo afectado principalmente por la limitada disponibilidad y el uso no racional de los recursos naturales que determinan baja productividad de los rebaños, pequeñas escalas de producción y una pobre integración de las cadenas productivas con las del mercado. Por otra parte, las poblaciones alto-andinas de Argentina y Chile no difieren mucho de las características observadas en Perú y Bolivia, aunque por la menor cantidad de animales y productores el impacto de su producción en las economías nacionales es también menor.

Respecto a los camélidos salvajes en los países andinos, éstos se encuentran protegidos por diversas leyes y normas nacionales e internacionales por lo que su aprovechamiento comercial es limitado, puntual y sujeto a un estricto control legal. En general los camélidos silvestres se consideran propiedad del Estado. Por ello no es posible contabilizar un número de "productores" de estos camélidos silvestres sino más bien unidades de aprovechamiento o de manejo. Existen algunos pocos criaderos de vicuñas y guanacos en cautividad donde los animales sí son propiedad de productores individuales. Las fibras finas de la vicuña son extremadamente valiosas y especiales no sólo por sus características textiles sino también por su escasez y por su asociación con ambientes y culturas exóticas. Así también el hilo y las prendas hechas de fibra de guanaco y vicuña tienen un alto precio en el mercado pero requieren materia prima adecuada.

Se considera que la alpaca es la especie productora de fibra por excelencia. Aun con una población menor a la de las llamas, la producción de fibra de alpaca es considerablemente mayor a la de llama. De cualquier manera, la importancia económica de cada especie de camélidos reside en la cantidad de productos y servicios que le presta al productor por lo que las llamas aportan incluso más que las alpacas. Otro aspecto a tener en cuenta aparte de la cantidad producida es el valor agregado que alcanza la fibra a nivel del productor, comunidad, industria o país. En ese aspecto las fibras de camélidos suelen alcanzar altos valores en los productos finales, aunque la participación del productor en ese valor generalmente es pequeña. 
En los últimos años se ha considerado de gran importancia la documentación de los recursos genéticos existentes en distintas especies, incluyendo la descripción de las características de la población fenotípicas, rendimiento, importancia cultural y la singularidad genética como una de las tareas principales de las actividades ganaderas de conservación. También la descripción de la diversidad genética es de gran utilidad para orientar el aprovechamiento sostenible y la intensificación de la producción animal y mantener o mejorar la capacidad para recuperar especies amenazadas.

Las poblaciones nativas de camélidos sudamericanos también requieren estudios de variabilidad genética, su distribución en las poblaciones de cada especie, así como identificar nuevos genes que indican la presencia de variantes genéticas únicas en cada unidad de manejo, localidad o país. La presencia de estas variantes únicas podrían servir en posibles `procesos de adaptación frente a cambios drásticos del clima, presencia de nuevas enfermedades o modificaciones de los objetivos de selección.

A partir de estudios previos de caracterización de especies de camélidos sudamericanos en países como Perú, Argentina y Chile (Sarno et al., 2001; Bustamante et al., 2002; Sarno et al., 2004; Maté et al., 2005; Bustamante et al., 2006; Marín et al., 2007a, 2007b, 2008) es posible inferir la existencia de una marcada diferencia en los niveles de diversidad genética y estructura poblacional entre las especies salvajes y domésticas de camélidos sudamericanos. Esas diferencias serían consecuencia de la historia, dinámica, espacio geográfico y manejo poblacional particular de cada región. Los datos sobre el conocimiento histórico de las poblaciones analizadas son de gran importancia para la interpretación de factores que puedan afectar a la diversidad y estructura genética de las poblaciones. En los últimos tiempos los marcadores de ADN microsatélite y ADN mitocondrial (ADNmt) se han convertido en herramientas moleculares de gran utilidad para evaluar la variabilidad y estructura genética de las poblaciones. En el caso de Bolivia, las poblaciones de camélidos no han sido objeto de estudio genético que nos permita conocer ni la variabilidad, ni la estructura genética de los camélidos en este país. En este contexto el grupo de investigación dirigido por la Doctora Volga Íñiguez Rojas, del Instituto de Biología Molecular y Biotecnología de la Universidad Mayor de San Andrés en La Paz, se propuso llenar esta laguna y completar 
el análisis de la variabilidad y estructura genética de las especies de Camélidos Bolivianos. Para ello y contactando con el grupo de Mejora Genética Animal, de la Universidad de León, donde se ha desarrollado la presente Tesis doctoral, y al amparo de la financiación de los proyectos de colaboración del Ministerio de Asuntos Exteriores y Cooperación del Gobierno de España (Referencias A/010497/07 y A/017114/08) se pudieron plantear los objetivos que se detallan a continuación.

\section{OBJETIVOS}

Como se ha indicado, Bolivia es el primer país en el mundo productor de llama y segundo de alpaca y apenas existen estudios de diversidad genética de las poblaciones de camélidos autóctonas. En base a este hecho y dada la creciente importancia que estás poblaciones tienen para el desarrollo económico y social de este país, la presente memoria de Tesis Doctoral se ha propuesto como objetivo global el estudio de la diversidad y estructura de las poblaciones bolivianas de camélidos sudamericanos. Dicho objetivo se puede desglosar en tres objetivos específicos.

- Estudio de la diversidad y estructura genética de la llamas bolivianas utilizando marcadores nucleares tipo microsatélite.

- Estudio de la diversidad y estructura genética de las alpacas bolivianas utilizando marcadores nucleares tipo microsatélite.

- Estudio de la diversidad genética en base al análisis de secuencias de ADNmt de las poblaciones de llamas, alpacas y vicuñas bolivianas. La información generada en base a este objetivo también se utilizará para analizar las relaciones filogenéticas entre las cuatro especies de camélidos sudamericanos, intentando aportar información adicional que ayude a determinar el papel de las poblaciones de camélidos bolivianos en relación a los procesos de domesticación que tuvieron lugar de las especies domésticas a partir de sus precursores salvajes. 
REVISION BIBLIOGRÁFICA 



\section{Origen y evolución de los camélidos sudamericanos}

Si atendemos a la clasificación taxonómica, los camélidos actuales pertenecen a la clase Mammalia, orden Artiodactyla, suborden Tylopoda y Familia Camelidae. Existen en este momento seis especies, tres de ellas domésticas, divididas en dos tribus, la tribu Camelini, que incluye a los camélidos del Viejo Mundo (presentan joroba), y la tribu Lamini, que contiene las cuatro especies de camélidos sudamericanos. En el Viejo Mundo han persistido dos especies del genero Camelus: el Camelus dromedarius o dromedario que se extiende por las zonas áridas y semi-áridas del continente africano, la región sudoccidental de Asia y buena parte del continente Australiano; y el Camelus bactrianus que está localizado en zonas desérticas de China y Mongolia y presenta ejemplares domesticados en estas mismas regiones. Los camélidos sudamericanos están constituidos por dos géneros, cada uno incluye una especie salvaje y otra doméstica. El género Lama presenta al guanaco (L. guanicoe) como especie salvaje y a la llama ( $L$ glama) como doméstica. Por su parte el género Vicugna engloba a la alpaca doméstica (V. pacos) y a la vicuña (V. vicugna) como especie salvaje (Franklin, 2011).

Los camélidos se originaron hace aproximadamente 40 a 45 millones de años, durante el período del Eoceno en la zona de montañas y planicies norteamericanas (Wheeler et al., 2006). Posteriormente durante el Oligoceno (hace 12-18 millones de años atrás), se produjo una radiación adaptativa en los camélidos y la división en cuatro grandes ramas que incluía nueve géneros y 17 especies. Durante la crisis del Messinense (hace unos 5-6 millones de años) se produjo un cambio climático que incluyó la aparición de un periodo de temperaturas muy bajas que destruyó una gran parte del hábitat del Mioceno. En el caso de los camélidos solo los Camelini y Laminini sobrevivieron a esta crisis climática. En este mismo período atravesaron el paso congelado que constituye actualmente el estrecho de Bering colonizando Euroasia, llegando incluso hasta la península Ibérica y África. Esta población dio lugar a las dos especies actuales, camello bactriano y dromedario que se separaron hace unos 5 millones de años (Wheeler, 1991).

La tribu Lamini fue descendiendo hacia América del Sur, atravesando América Central por el Istmo de Panamá (Vargas, 2005). Al final del Pleistoceno, hace 10 a 12 mil 
años, Camelops, Hemiauchenia y Pleolama desaparecieron, quedando Lama y Vicugna como los únicos géneros sobrevivientes de la tribu Lamini (Wheeler, 1991).

La diversificación de los camélidos del Nuevo Mundo tuvo lugar en los Andes Centrales y del Sur, en territorios correspondientes actualmente a Perú, Bolivia y Argentina, desarrollándose las cuatro especies de camélidos sudamericanos mencionadas anteriormente (Vargas, 2005).

En 1758, Linneus describe por primera vez las dos formas domésticas de camélidos del Nuevo Mundo como Camelus glama (llama) y Camelus pacos (alpaca) y los ubica junto a camellos como Camelus bactrianus y al dromedario como Camelus dromedarius. Linneus, sin embargo, no incluye a los camélidos sudamericanos salvajes en su clasificación. Años más tarde, Müller describe al guanaco como Camelus guanicoe en 1776 y Molina describe a la vicuña como Camelus vicugna en 1782. Fue G. Cuvier, en 1805 quién clasificó los camélidos del Nuevo Mundo en el género Lama y los del Viejo Mundo en Camelus, propuesta aceptada en 1958 por la Comisión Internacional de Nomenclatura Zoológica. En 1924, Miller separa a la vicuña en el género Vicugna, basado en su observación del crecimiento continuo de los incisivos, sin embargo no incluyó muestras de alpaca, llama o híbridos, y debido a esta omisión alpaca, llama y guanaco se agruparon durante largo tiempo dentro el género Lama, donde el guanaco sería la especie ancestral (Marín et al., 2007b), y la vicuña quedaba como una especie salvaje que nunca fue domesticada. Según la clasificación más actual que hemos encontrado, como se ha indicado, alpaca y vicuña se engloban dentro del género Vicugna y llama y guanaco dentro del género Lama (Franklin, 2011), esto en base a los estudios sobre restos arqueológicos de incisivos de alpaca, vicuña y llama (Wheeler, 1982, 1984) y estudios sobre ADNmt y cuatro marcadores microsatélite realizados por Kadwell et al. en el 2001, y por análisis de ADNmt y bandeo cromosómico realizado por Marín et al. (2007b), que apoyan esta hipótesis.

A nivel cromosómico, se ha confirmado que los cariotipos de los camélidos del Viejo y Nuevo Mundo son similares al presentar 74 cromosomas (2n). Se realizaron cruces experimentales en los Emiratos Árabes de llama con dromedario, cuyo híbrido resulto el 
Lamacame, lo que demuestra que esta familia ha mantenido sus rasgos genéticos comunes durante 40 a 45 millones de años (Salinas, 1998). Como habíamos mencionado anteriormente, Marín et al. (2007) por bandeo de cromosomas observaron que los patrones de bandas $\mathrm{G}$ y $\mathrm{C}$ en los camélidos sudamericanos son muy similares a las descritas para camello, Camelus bactrianus. A mayor resolución existen diferencias consistentes en el patrón de bandas $\mathrm{G}$ de los brazos cortos del par 1 entre guanaco y vicuña. El patrón de bandas presentado en guanaco también fue observado en todas las llamas reportadas. El patrón de vicuña fue observado también en todas las alpacas, mientras que en el híbrido se observa bandas de los dos grupos analizados.

\section{Clasificación de los camélidos sudamericanos}

Los camélidos sudamericanos se agrupan en camélidos silvestres y camélidos domésticos. Entre las especies salvajes encontramos al guanaco (Lama guanicoe), considerado el artiodáctilo silvestre más grande de Sudamérica. Se han descrito cuatro subespecies geográficas, descritas en base a medidas corporales, color de la piel, medidas y proporciones del cráneo y algunas otras variables (González et al., 2006).

A principios del siglo XX se describieron las subespecies $L$. g. cacsilensis; $L$. $g$. voglii; L. g. huanacus y L. g. guanicoe. L. g. cacsilensis habita los Altos Andes de Perú, Bolivia y el noreste chileno mientras que L. g. huanacus se encuentra solo en Chile, según Molina (1782), L. g. voglii (Krumbiegel, 1944) en la vertiente oriental de los Andes argentinos $21^{\circ}$ y $32^{\circ}$ latitud sur y L. g. guanicoe (Müller, 1776) con distribución en la Patagonia, Tierra del Fuego y Argentina al sur. Sin embargo, estudios recientes en base a ADNmt han demostrado la existencia de dos subespecies: Lama guanicoe cacselinsis (8

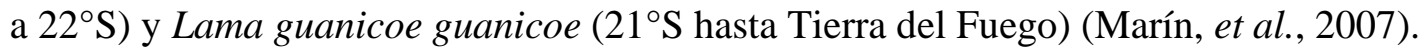

El otro camélido salvaje es la vicuña (Vicugna vicugna). Es el más pequeño y frágil de los camélidos sudamericanos silvestres y se han descrito dos subespecies geográficas: Vicugna vicugna (Molina, 1782) y V. v. mensalis (Thomas, 1917). La primera se distribuye al sur del paralelo $18^{\circ}$. La otra subespecie geográfica (V. v. mensalis) al norte de su ámbito de distribución. Se han encontrado evidencias genéticas de su separación (Sarno et al., 2004, Marín et al., 2007a) aunque trabajos anteriores realizados con 
marcadores isoenzimáticos habían demostrado una distancia genética insuficiente entre ambas subespecies considerándola una sola subespecie ( $V$. vicugna) (Norambuena y Paredes, 2003).

Respecto a los camélidos sudamericanos domésticos, la llama (Lama glama) es el más grande de los camélidos domésticos y se asemeja en muchos aspectos morfológicos y comportamentales a su progenitor silvestre, el guanaco. Se reconocen dos tipos de llamas: Q'aras y T'hamphullis, notoriamente diferenciadas las primeras por su menor rendimiento en vellón y menor calidad de fibra (Wheeler, 1991; Iñiguez et al., 1998; Stemmer et al., 2005) mientras que las segundas producen un vellón de mayor peso (Stemmer et al., 2005) y con menor medulación.

Finalmente, el otro de los camélidos domésticos conocido es la alpaca (V. pacos), que es considerablemente más pequeña que la llama. Existen dos razas establecidas: Huacaya, que se caracteriza por tener un vellón muy parecido al del ovino Corriedale, compuesto por fibras finas de unas 24 micras perpendiculares al cuerpo de buena longitud y presencia de ondulaciones. La otra raza es la Suri que se caracteriza por tener el vellón como el del ovino de Lincoln, con fibras más finas que la Huacaya, agrupadas en mechas rizadas que crecen paralelas al cuerpo (FAO, 2005).

\section{Distribución y hábitat de los camélidos sudamericanos}

El hábitat de los camélidos sudamericanos incluye formaciones ecológicas particulares de Puna y Altos Andes que se encuentran distribuidas desde el norte del Perú hasta el norte de Argentina, incluyendo áreas altoandinas de Bolivia y Chile. y cuyas características generales son la presencia de mayor humedad hacia el norte y áreas secas hacia el sur. La altitud de las punas oscila entre los 3.800 y $5.000 \mathrm{msm}$ con una temperatura promedio de $6^{\circ} \mathrm{C}$ a $8^{\circ} \mathrm{C}$ y 400 y $700 \mathrm{~mm}$ de precipitación. En general, los camélidos pueden vivir desde el nivel del mar hasta más de 5.000 m de altitud.

También es importante mencionar que alpacas y llamas también fueron llevadas a otros países, donde son criadas en condiciones más favorables que las de su ambiente de origen, y que en la actualidad son usadas como mascotas o para producir fibra; así en los 
Estados Unidos existen aproximadamente 120.000 animales, y también se pueden encontrar estas especies en Australia (100.000 animales), Canadá, Nueva Zelanda y otros países europeos como el Reino Unido, Alemania, Italia y Francia. También existen explotaciones de estos animales en España. En la mayoría de estos países se utilizan para la producción de fibra o como animales de compañía.

\subsection{Guanaco}

El rango de distribución del guanaco es amplio (Fig. 1), presentándose en forma de parches entre el norte del Perú y Tierra del Fuego (Argentina), desde el nivel del mar hasta los $4.600 \mathrm{~m}$ de altitud. Por efecto de la cacería indiscriminada y el deterioro de sus hábitats naturales, principalmente por la competencia con el ganado doméstico y efectos climáticos adversos como intensas nevadas (Franklin, 1982) esta especie sufrió una retracción del 58 \% en Argentina, y del 75 \% en Chile y Perú, y está reducida a su mínima expresión en las formaciones chaqueñas de Bolivia y Paraguay, mientras que en Ecuador se considera extinguida. Se distribuye desde los $8^{\circ}$ en Perú hasta cerca de los $55^{\circ}$ de latitud Sur en la Isla de Tierra del Fuego (Argentina y Chile). El guanaco a nivel internacional se encuentra en la categoría de Bajo Riesgo (LR.lc) (UICN, 1996). Considerando la poca información existente sobre el tamaño de sus poblaciones y la calidad de los hábitats que ocupa, se considera que aproximadamente el 91 \% de la población total se encuentra en Argentina, donde no está considerada en peligro de extinción, el $9 \%$ en Chile, donde es considerada Vulnerable, mientras que las poblaciones localizadas en Bolivia ( $<0.02 \%)$, Paraguay ( $<0.01 \%)$ y Perú $(<0.5 \%)$ son consideradas En Peligro (EN).

En la Fig. 1 poblaciones de L. g. cacsilensis (Krumbiegel, 1944) se encuentran distribuidas en territorios correspondientes a Perú, norte de Chile y Bolivia (8 ${ }^{\circ} \mathrm{S}$ y 22 $\left.{ }^{\circ} \mathrm{S}\right)$. En cambio, según Wheeler (1995), L. g. voglii estaría distribuida entre $21^{\circ}$ y $32^{\circ} \mathrm{S}$ en las laderas orientales de los Andes argentinos, sin embargo Franklin (1982) amplió su distribución hacia el norte, más allá de $32^{\circ} \mathrm{S}$ a través de las zonas áridas y llanuras de Argentina y posiblemente Paraguay. Cuéllar \& Fuentes (2000) sugieren que esta forma también habita en Bolivia. 
En cuanto a la distribución de $L$. g. guanicoe, existe cierta confusión en el establecimiento de los límites de distribución de esta subespecie. Krumbiegel (1944) consideró que la distribución oscila entre Patagonia y Tierra del Fuego hasta el límite norte de los $35^{\circ} \mathrm{S}$. Wheeler (1995) reportó que este taxón puede extenderse desde la vertiente occidental de los Andes a lo largo de Patagonia desde $32^{\circ}$ hasta $55^{\circ} \mathrm{S}$. La distribución de L. g. huanacus es ambigua, aunque se restringe a Chile. Wheeler (1995) restringe su distribución sólo a Chile entre $22^{\circ}$ y $28^{\circ} \mathrm{S}$.

En Bolivia, el guanaco ha sido históricamente registrado en las regiones altoandina y puna (en departamentos de Potosí y Chuquisaca) y llanura chaqueña (Tarija y Santa Cruz) (Tarifa, 1996). El último informe sobre el estado de conservación de la fauna en Bolivia indica que el guanaco de la región altoandina y puna estaría extinto en estado silvestre. Esta apreciación se hizo por la ausencia de observaciones de la especie en el campo por investigadores durante los últimos 18 años. Alzérreca (1982) registró a la especie en la región de Mochara (en el límite entre los departamentos de Potosí y Chuquisaca) y Pinaya (1990), al oeste de la Cordillera de Sama (en el departamento de Tarija). Esta información fue corroborada durante un taller de especialistas realizado en el 2001 (Flores \& Miranda, 2003). Las únicas observaciones directas de guanaco en estado silvestre en Bolivia fueron realizadas en la zona del Chaco, al sureste del departamento de Santa Cruz en la frontera con Paraguay repartidos entre ganaderías privadas y el territorio de la tribu indígena Isoseño-Guarani, que habita en los límites del Parque Nacional de Kaa-lya (KA, Fig. 1) (Cuéllar \& Fuentes, 2000), donde habita la subespecie L.g. voglii (recientemente sugerida como L. g. guanicoe) que se encuentra en riesgo de extinción (VU) al igual que la de Paraguay. Entre 1998 y 2001 se llevaron a cabo tres censos aéreos para determinar la distribución de la población del guanaco en esta zona chaqueña. En mayo de 1998, la población estimada fue de aproximadamente 200 individuos, y en abril de 2001 la estimación decayó a menos de 50 individuos, mientras que durante el último censo realizado en el 2002 sólo se observaron 21 individuos (Cuéllar \& Fuentes, 2000; Cuéllar et al., 2002). Esta condición de riesgo es consecuencia de las distintas presiones a la que están siendo sometidas dichas poblaciones chaqueñas (fragmentación de hábitat, presión de caza, falta de ordenamiento territorial). 
La zona donde habita esta forma de guanaco en Bolivia, consiste en una llanura aluvial, producto de los movimientos y deposiciones de sedimentos y arena del río Parapetí. La vegetación está representada por un mosaico de vegetación, sobre suelos bien drenados, consistentes en pampas, matorrales, arbustedas, y formaciones de bosques nativos remanentes. La altitud va de 300 a 450 msnm, la temperatura promedio es de 26 ${ }^{\circ} \mathrm{C}$, con una extensa época seca.

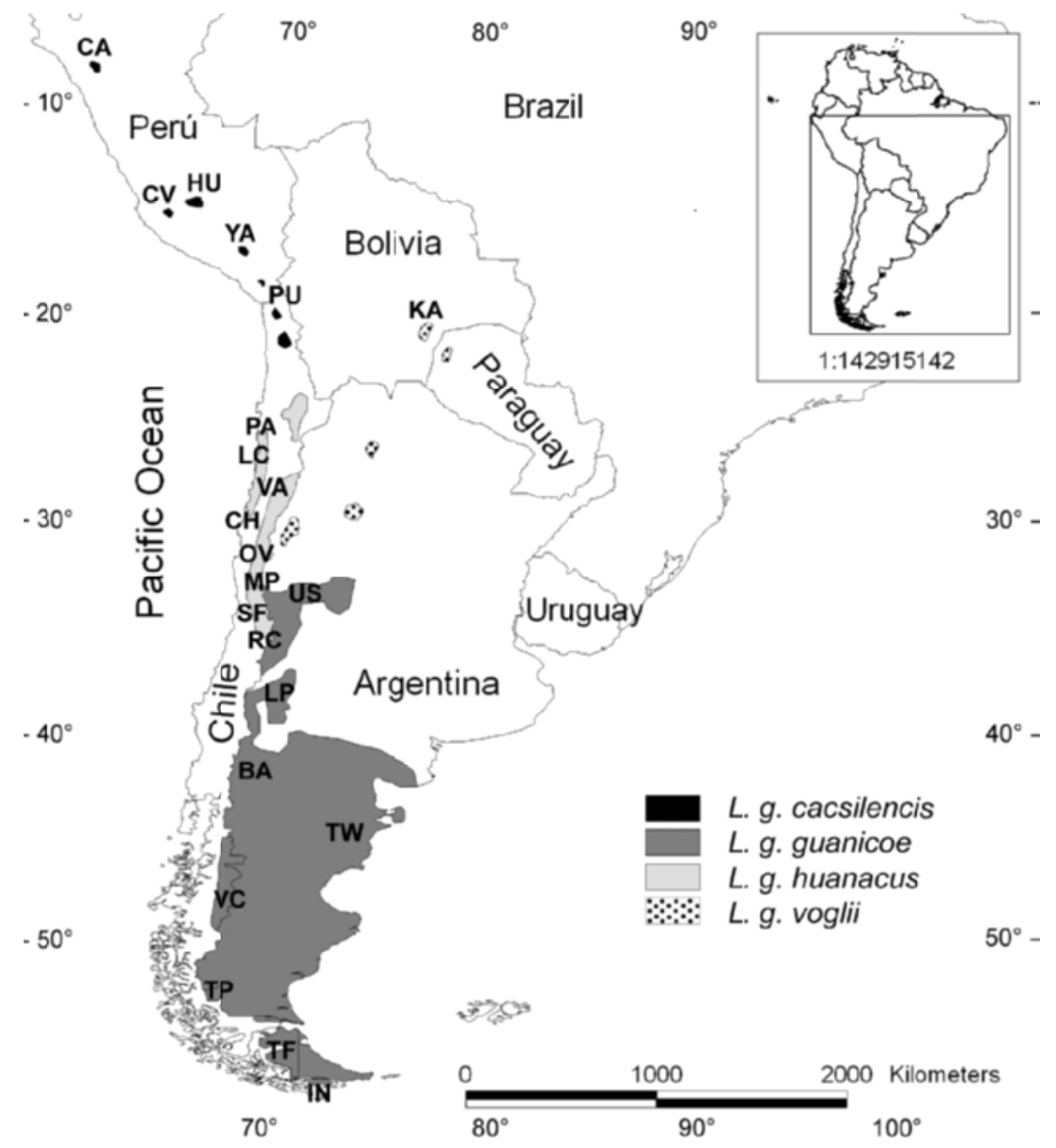

Figura 1. Distribución geográfica de las subespecies de guanaco en Sudamérica. Tomado de Marín et al. (2008).

\subsection{Vicuña}

La distribución de la vicuña históricamente ocupaba la región andina del sudeste peruano y oeste boliviano, noreste chileno y noroeste argentino entre los $7^{\circ}$ y $34^{\circ}$ latitud sur (Hofmann, 1971). En la actualidad la distribución de vicuñas es menor, desde el 
paralelo $9^{\circ} \mathrm{S}$ del Parque Nacional Huascarán en Perú hasta $27^{\circ}$ de latitud sur en las provincias de Atacama, Chile y San Juan de Argentina (Hofman et al., 1983), existiendo vicuñas en Argentina, Bolivia, Chile y Perú de forma natural y una población reintroducida en el Ecuador (Laker et al., 2006). Se encuentran entre los 3.300 y 4.300 msm con temperaturas que fluctúan entre $8^{\circ}$ y $17^{\circ} \mathrm{C}$ y precipitación anual que no supera los 1000 mm, donde la vegetación está restringida a pocas especies (Laker et al., 2006). Se han descrito dos subespecies geográficas: la primera, $V$. $v$. vicugna, se encuentra al sur del paralelo de $18{ }^{\circ} \mathrm{S}$, es de mayor tamaño y de color más claro que la segunda o norteña, V.v. mensalis.

La disponibilidad de alimento no es continua, variando en calidad y cantidad. Durante los meses de noviembre y diciembre se encuentran los mejores pastos, mientras que la producción de mayo a julio proporciona mayor proteína, entre agosto y octubre el forraje aporta tanto proteína como energía, lo cual determina el éxito reproductivo (San Martín, 1996). Existe sin embargo, competencia por los recursos o hábitat en áreas simpátricas con guanacos, llamas o alpacas que afecta su actividad diaria (Donadio \& Buskirk, 2006). Los grupos familiares de vicuñas son más frecuentes en áreas con mayor cobertura vegetal, donde las hembras se dedican más tiempo al forrajeo, mientras que las tropillas de machos se encuentran en lugares con pendientes elevadas (Arzamendia \& Vilá, 2003; Arzamendia \& Vilá, 2006). La vegetación está formada por gramíneas duras y silificadas como Stipa ichu y Festuca dolichophylla. Existen zonas que permanecen anegadas todo el año, llamados bofedales, de excelente calidad para el pastoreo de camélidos. También existen matorrales de thola (Parastrephia spp y Baccharis spp) y relictos de bosquecillos de queñua (Polylepis spp).

La explotación de la vicuña ha reducido notablemente su rango de distribución y el tamaño de sus poblaciones por lo que en 1968 la UICN (Unión Internacional para la Conservación de la Naturaleza) la declaró como especie en vía de extinción. Un año más tarde Bolivia y Perú suscribieron el tratado de La Paz, donde acuerdan unir esfuerzos para proteger y recuperar a esta especie, al que posteriormente se adhieren Argentina (1971), Chile (1973) y Ecuador (1979), formándose el “Convenio para la conservación y manejo de la vicuña” (Llobet et al., 2003). 
De igual manera el Convenio Internacional de Especies Amenazadas (CITES) prohíbe la comercialización de fibra de vicuña hasta que las poblaciones sean susceptibles de aprovechamiento (Torres, 1992; Llobet et al., 2003). Estas medidas, junto a las políticas internas de cada país tales como leyes de protección y conservación de la especie en áreas protegidas, permitió recuperar las poblaciones de vicuñas hasta una población total de 283.000 individuos, de los cuales la mayor cantidad se encuentra en Perú (161.460 animales), seguido de Bolivia (61.000 animales), Argentina (45.000) y, en menor cantidad, de Chile y Ecuador (Laker et al., 2006).

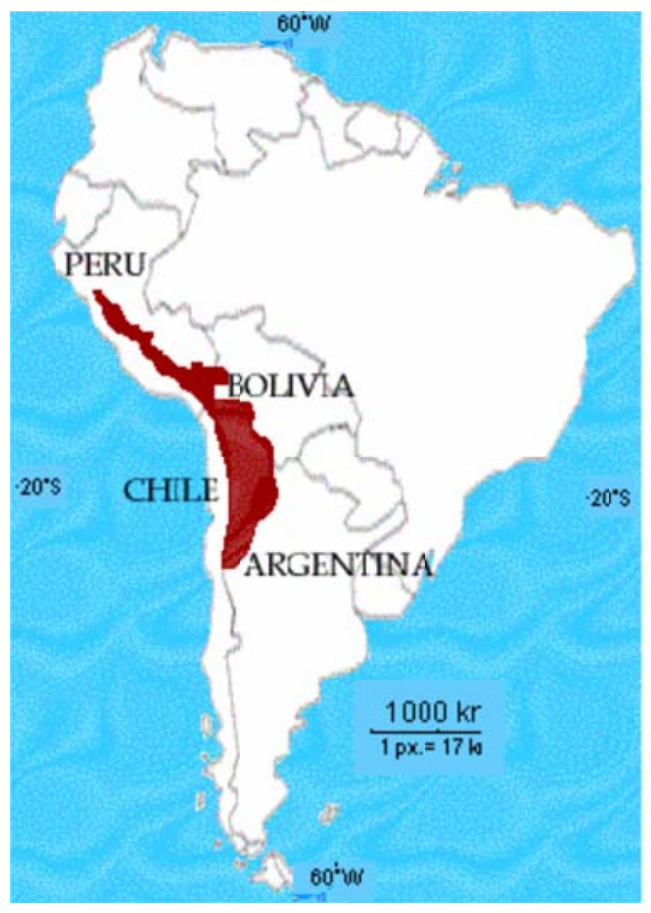

Figura 2- de la vicuña (V. vicugna) en la región andina. Tomado de Renaudeau d’Arc (2002).

La distribución de la vicuña en Bolivia se sitúa en la región altiplánica y altoandina de los departamentos de La Paz, Oruro, Potosí, Cochabamba y Tarija entre los 3,800 y $5.000 \mathrm{msm}$, en un área comprendida entre los $14^{\circ}$ y $22^{\circ}$ de latitud sur y $64^{\circ}$ y $69^{\circ}$ de longitud oeste, a lo largo de una superficie de 34,238 $\mathrm{Km}^{2}$ (Llobet et al., 2003). Los límites geográficos para ambas subespecies son ambiguas, sin embargo $V$. v. vicugna no estaría presente al norte del departamento de La Paz (Sarno et al., 2004). 
La explotación de la vicuña en Bolivia durante la época de la colonia y la república provocó la reducción drástica de las poblaciones, registrándose en el año 1965 un total nacional de 1097 vicuñas (INFOL, 1985). La población más afectada fue la de Ulla Ulla (ANMIN-Apolobamba), al norte del departamento de La Paz, con 97 individuos. En 1997 se reconocen tres áreas protegidas dentro el Sistema Nacional de Areas Protegidas (SNAP), a cargo del Servicio Nacional de Areas Protegidas (SERNAP, 2000): MauriDesaguadero, Apolobamba-Ulla Ulla y Sud Lípez como se muestra en la Fig. 3 (DNCB 1996, Llobet et al., 2003, DGByAP, 2007). En estos centros pilotos de conservación se logró incrementar las poblaciones de vicuñas posterior a la firma del tratado CITES donde se incluían a todas las poblaciones dentro del apéndice I.

Actualmente el manejo de vicuñas se realiza bajo distintas modalidades: en Argentina se permite el uso en cautiverio, en Chile y Perú algunas poblaciones se encuentran en semicautiverio, mientras en Bolivia solo se permite el uso en silvestría (Torres, 1992; Laker et al., 2006).

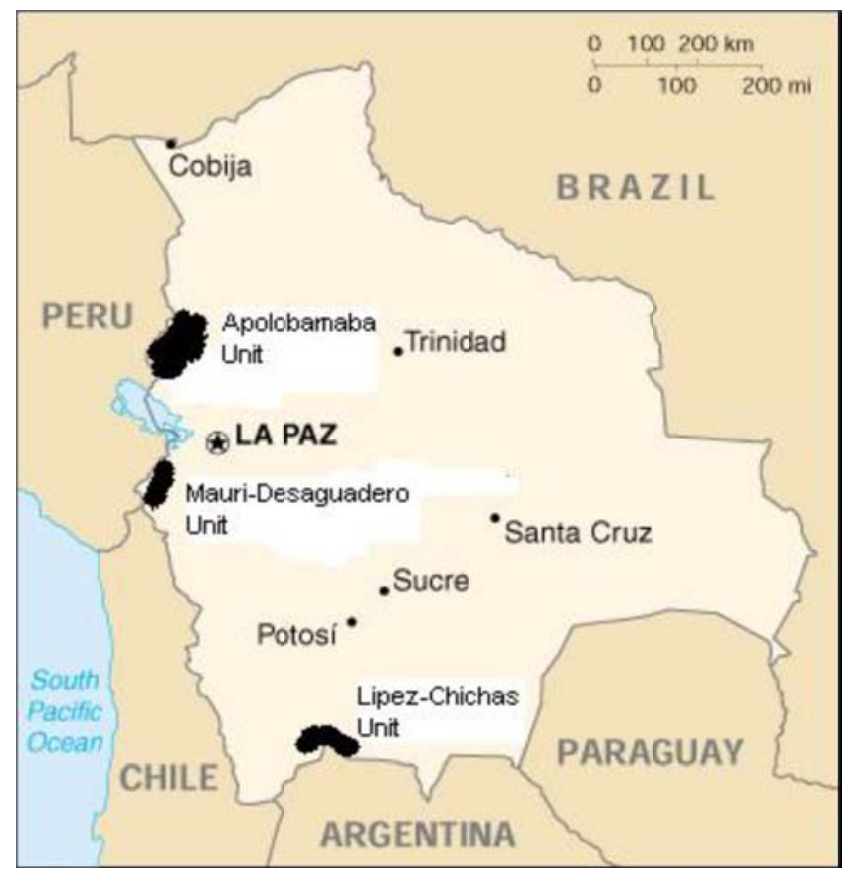

Figura 3- Unidades de manejo de las vicuñas en el Altiplano boliviano.

Tras años de actividad se mejoraron y actualizaron las técnicas de captura y esquila, con el objetivo de perfeccionar la obtención y almacenaje de la fibra para incrementar su 
valor. Estas experiencias han sido transmitidas a otras comunidades interesadas en este recurso (DGByAP, 2007).

\subsection{Alpaca}

La población mundial de alpaca es de 3.611, 730 animales distribuidos principalmente en el Perú con un $87 \%$, el 12 \% en Bolivia y el resto distribuido entre los EE.UU., Nueva Zelanda, Canadá y Australia (Fig. 4). Alrededor del 95 \% de la población de alpacas peruanas se encuentra en los Andes y es gestionada bajo un sistema extensivo tradicional que se caracteriza por bajos parámetros productivos y reproductivos. El 85 \% de la población de alpacas es del tipo llamado Huacaya y el 15 \% son de tipo Suri. En términos socioeconómicos, las alpacas se crían en los Andes para la producción de carne (mercado local) y fibra que proporciona el 82 \% de la demanda en todo el mundo y proporciona ingresos a más de 500.000 familias en zonas de gran altitud.

Las alpacas tipo huacaya son más resistentes al frío porque tienen fibra voluminosa. Las alpacas suris necesitan más atención cuando hace frío porque su fibra posee bucles que no proporciona adecuado aislamiento. La diferencia entre las dos es la fibra y el peso vivo; las alpacas suris tienen mayor peso vivo, fibra más larga y pesada que las huacayas. Las alpacas se encuentran en elevaciones de 3700 hasta 4800 msm, y son estrictamente herbívoros selectivos, prefiriendo la vegetación de las praderas de tierras bajas y pantanos llamados bofedales. Las alpacas son principales productores de fibras animales en la región del Altiplano en Bolivia, Perú, Argentina y Chile.

Desde su domesticación, hace 6.000 años en las punas centrales del Perú, la crianza de alpacas fue llevada por el hombre a los valles interandinos hace 3.800 años, según evidencias procedentes de los sitios arqueológicos de Huanuco a 1.900 msm y de Cajamarca a 2.700 msm. Finalmente, es probable que se extendiera a las costas del norte y sur hace 900 a 1.000 años. Actualmente la distribución de la alpaca se extiende desde Cajamarca (de reciente reintroducción) y el norte del departamento de Ancash, hasta el Lago Poopó, en Bolivia, norte de Chile y noroeste de Argentina. En toda esta área se registran elevaciones de $4.000 \mathrm{msm}$ o superiores. Aunque no existen evidencias 
paleontológicas, ni arquezoológicas de la presencia de alpacas en Ecuador, en 1987 se han introducido alpacas chilenas a los Andes ecuatorianos.

En Bolivia, la población estimada de alpacas es de 456.784 alpacas (MACA, 2003). Los departamentos con mayor población de alpacas son La Paz y Oruro, con el 50.9 \% y $45 \%$, respectivamente. Las alpacas se alimentan exclusivamente del forraje disponible en la pradera nativa, mediante pastoreo extensivo. El deterioro de las praderas (bofedales) por sobrepastoreo es evidente, observándose una sobrecarga animal de 2.2 unidades de alpaca por hectárea en la zona de Ulla Ulla.

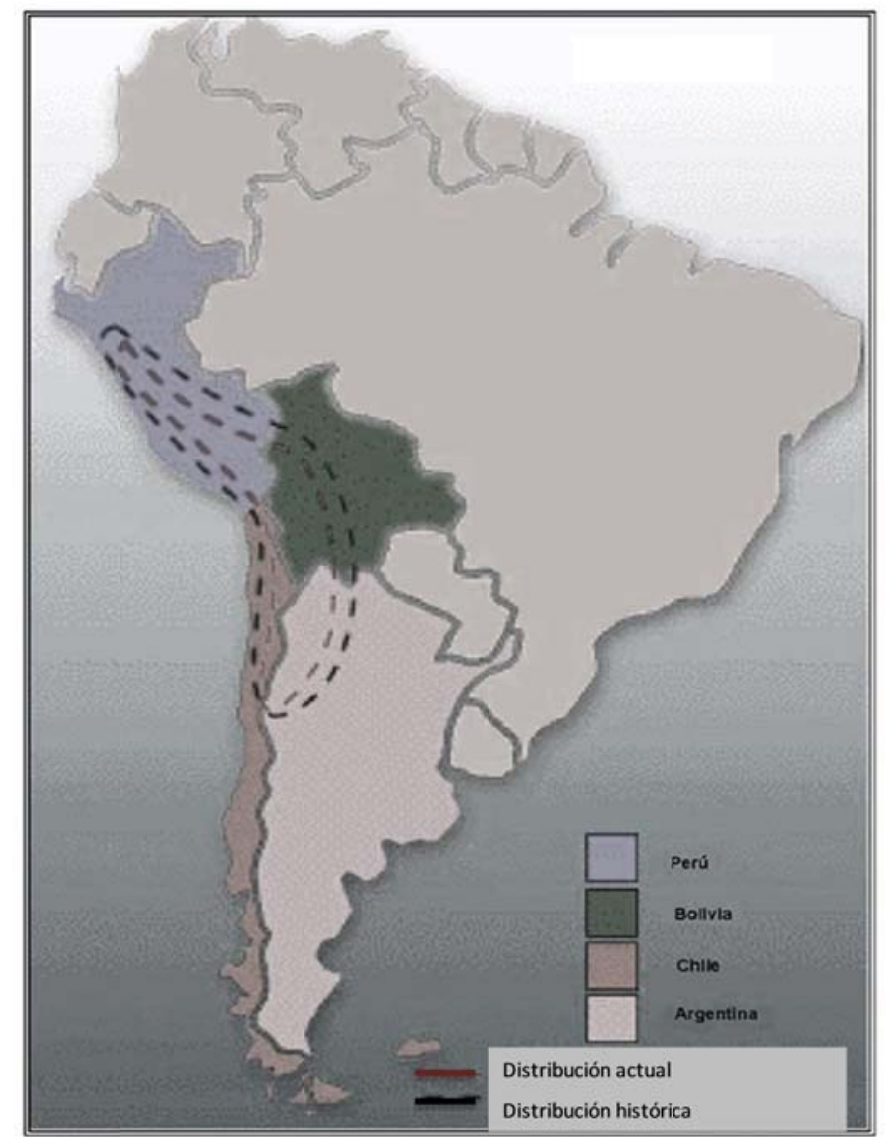

Figura 4- Distribución histórica y actual de la alpaca en la región andina.

\subsection{Llama}

Igual que su progenitor el guanaco, la llama se ha adaptado a un amplio rango de condiciones medioambientales. Después de su domesticación en las punas peruanas, hace 
aproximadamente 6.000 años (Wheeler, 1984; Wing, 1977, 1986), la llama fue llevada por el hombre a los valles interandinos peruanos y al norte de Chile donde se han encontrados restos en sitios arqueológicos con una antigüedad de 3,800 años (Wing, 1986). La crianza de llamas se extendió, 2,400 años más tarde, a la costa norte de Perú (Shimada \& Shimada, 1985) y al Ecuador (Wing, 1986) llegando a jugar un rol importante en la economía local de ambas regiones. Se conoce que durante el Incanato (1470-1532) caravanas de llamas solían acompañar a los ejércitos reales, extendiendo de esta manera la distribución de esta especie a lo largo de los Andes desde el sur de Colombia a la zona central de Chile. La distribución actual de la llama se extiende al sur hasta aproximadamente el $27^{\circ} \mathrm{S}$ en el centro de Chile, pero la zona de mayor productividad está ubicada entre $11^{\circ}$ y $21^{\circ} \mathrm{S}$, entre elevaciones de 3,800 a $5.000 \mathrm{msm}$.

En Bolivia, la población estimada en el año 2003 fue de 2.622 .310 animales, siendo este país el mayor productor de llamas en el mundo. El departamento de Oruro posee el 50 \% de la población de llamas, Potosí el 33 \% y La Paz el 13 \%. La población dedicada a la cría de ganado camélido en el Altiplano boliviano es de aproximadamente 54.000 familias (Vargas, 2005). El Altiplano boliviano es una planicie de altura con varias serranías, que se extiende en cerca de $100.000 \mathrm{~km}^{2}$. Corresponde a una antigua depresión lacustre entre la Cordillera Real al Este y la Cordillera Oriental de la cual quedan solamente la cuenca endorreica del lago Titicaca, lagos y salares altiplánicos. Más de la cuarta parte de la población rural boliviana vive en el Altiplano (1.581.324 habitantes). La pluviometría decrece $(800$ a $200 \mathrm{~mm})$ y la temperatura promedio baja $\left(10^{\circ} \mathrm{C}\right.$ a $\left.5^{\circ} \mathrm{C}\right)$ según un gradiente Norte-Sur, lo que define una aridez creciente hacia el Sur. Se puede distinguir entonces el Altiplano norte con precipitaciones de 600 a 800 mm, el Altiplano central con precipitaciones promedio de $400 \mathrm{~mm}$ (300-500 mm) y el Altiplano sur con precipitaciones inferiores a $300 \mathrm{~mm}$, que corresponden respectivamente a la puna semihúmeda, semi-árida y árida.

Los sistemas vegetales principales que conforman casi la totalidad del paisaje vegetal son pajonales (Stipa ichu, Calamagrostis, Festuca ortophylla), tolares (Baccharis incarum, Baccharis santelisis), gramadales (D. humilis, Juniellia minima), chilluares (Festuca dolichophklla) y bofedales (Distichia muscoides, Oxychloe andina). 
En Bolivia existen sistemas generales de producción, en función de los distintos sistemas vegetales, donde se crían a los camélidos (Fig. 5), la mayoría de estos sistemas se caracterizan por ser mixtos, incluyendo la cría y explotación de dos o más especies. Las regiones presentan condiciones de puna y en ocasiones pequeños valles donde la cría de camélidos está asociada a caprinos (Vargas, 2005).

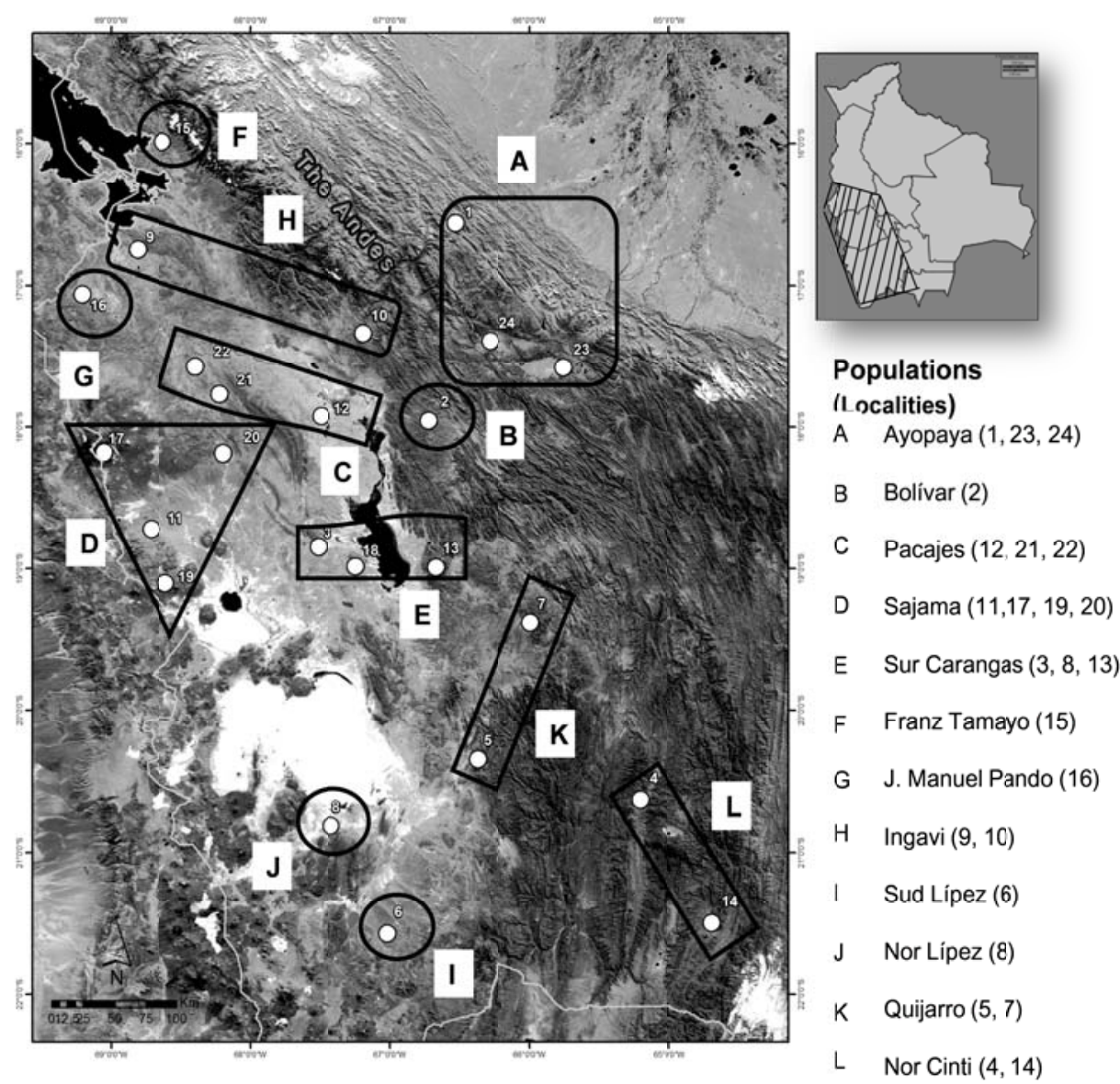

Figura 5- . Distribución de llamas en Bolivia y agrupaciones por sistemas de producción.

La región oeste del Altiplano central (comprende los ejes territoriales de José Manuel Pando-Charaña, La Paz-Sajama y Oruro-Turco) presenta un sistema mixto de alpacas, llamas y ovinos. La finalidad de este sistema es producir carne de llama y ovinos, y fibra de alpaca. La formación vegetal predominante en las partes altas de las serranías son pajonales. En las laderas bajas de las serranías las formaciones más importantes son el tolar y el tolar-pajonal, en las regiones de pampa se encuentra una alta frecuencia de comunidades vegetales de "Iru Ichu" (Festuca orthopylla) y menores superficies 
cubiertas por comunidades de gramíneas bajas con predominancia de Festuca dolicophyla.

La región de las pampas del oeste y centro del Altiplano Central (Oruro-Turco tiene su zona de producción en las Provincias Atahuallpa, Litoral, Sur de Sajama, Saucarí, Carangas, Mejillones y Sur Carangas del Departamento de Oruro). Comercialmente, está conectada al mercado de la ciudad de Oruro y, desde allí, se conecta con otras ciudades como La Paz, Cochabamba y Santa Cruz y el norte chileno, y se caracteriza por la ausencia de bofedales y alpacas. Las comunidades vegetales son las mismas que las descritas en las provincias Pacajes y Sajama. La producción principal es la carne de llama, que se comercializa a través de intermediarios. En esta región Festuca orthopylla, una gramínea perenne, Stipa rigidiseta y Calamagrostis antoniana son las especies dominantes. La principal forma de uso de esta asociación vegetal es el pastoreo de llamas y ovejas.

La región localizada entre Uuyni-Sur Lípez está ubicada en las Provincias Sur Lípez, Enrique Baldivieso y Quijarro del Departamento de Potosí. Esta zona se vincula comercialmente al mercado de Challapata, Provincia Avaroa del Departamento de Oruro, y desde ahí, con las ciudades más importantes del país, se caracteriza por ser una región mixta de crianza de llamas, ovinos y caprinos. Pajonales de Ichu en laderas y pampas son las principales formaciones vegetales, cuenta además con bofedales.

Finalmente el sistema de Cochabamba-Ayopaya tiene su zona de producción en la Provincia Ayopaya del Departamento de Cochabamba; comercialmente está conectada al mercado de Cochabamba a través de Quillacollo. En las praderas altoandinas, la llama se alimenta principalmente de pajonales, tolares, gramadales teniendo una alta selección de gramíneas secas, altas y fibrosas, y realizando una menor selección de hojas, en contraste a las alpacas, que se alimentan principalmente en bofedales con preferencia de plantas herbáceas con mayor contenido de agua. Por tanto el consumo de agua es mayor en alpacas que en llamas.

Uno de los principales problemas en la ganadería camélida es el sobrepastoreo, debido a una carga animal (sobrecarga de 0,18 unidades de llamas/ha), lo que ocasiona un 
marcado déficit alimenticio, especialmente durante el invierno. Otro problema para la producción de camélidos es la alta tasa de mortalidad (51, 28 \%) respecto a la producción total.

\section{Caracterización biológica de los camélidos sudamericanos}

Los Camélidos Sudamericanos presentan una serie de características biológicas que los diferencia en relación a los patrones básicos de los mamíferos. Así su fisiología cardiovascular y respiratoria tiene condiciones propias compensando eficazmente la hipoxia a la que están sometidos, además de presentar el mismo gasto cardíaco que los animales que se encuentran a nivel del mar, pero con una frecuencia cardíaca menor. A nivel tisular disponen de una gran superficie de intercambio y transporte de gases, lo que facilita la disponibilidad de oxígeno. Es posible apreciar la peculiar forma elíptica de los glóbulos rojos, su pequeño tamaño, de 6,5 x 3,3 micras, se compensa con su elevado recuento total (14 millones/mm3). Esta alta producción es compensada con altas tasas de recambio siendo la vida media de los eritrocitos de 60 días.

La presencia de almohadillas plantares en todos los camélidos, a diferencia de la tradicional suela córnea que conforma el casco, permite a estas especies adecuarse al frágil ecosistema andino, sin causar una erosión marcada como pasaría con otras especies de su mismo tamaño, por lo que son considerados animales ecológicos. También difieren de los otros rumiantes por no presentar cuernos o astas. Tanto los Camélidos del Viejo Mundo como los sudamericanos presentan una adaptación en los mecanismos economizadores de agua lo que facilita su ubicación en áreas altiplánicas, generalmente de ladera y con escasez de agua. Esta adaptación se basa en su capacidad para utilizar forrajes secos poco nutritivos y en el reducido consumo de agua. La escasez de alimento y agua, normalmente en la época invernal, provoca una reducción de los índices de producción afectando especialmente su rendimiento en carne, fibra y la tasa de parición (Álvarez-Romero \& Medellín, 2005).

Otra característica importante es que no presentan rasgos nítidos de dimorfismo sexual. Todos los Camélidos actuales poseen un mismo número de cromosomas $2 \mathrm{~N}=74$. Esta característica está muy relacionada con la capacidad de cruces fértiles. Esto también 
ocurre con los Camélidos del Viejo Mundo, donde es posible la obtención de híbridos fértiles, sean machos o hembras.

Los camélidos exhiben procesos básicos de rumia, pero se diferencian del suborden Pecora (rumiantes), de los que se separaron hace 30 a 40 millones de años, por la morfología del estómago (presentan sólo tres compartimentos). Muestran presencia de verdaderos caninos separados de los premolares por diastema.

Tanto los camellos como los camélidos sudamericanos son paseadores naturales. En contraste con el trote, caracterizado por el apoyo alterno de cada bípedo diagonal, el paso es marcado, alzando simultáneamente ambas extremidades del mismo lado. Este movimiento produce un tranco más largo permitiendo al paseador cubrir más distancia con menos gasto de energía; solamente los camellos y camélidos sudamericanos tienen conformación morfológica especializada para la práctica habitual del paso. La elongación del cuello y las piernas, la posición de los extremidades cerca de la línea central del cuerpo junto con el estrechamiento de la cavidad torácica, la fusión de los metapodios III y IV en un solo hueso ligeramente bifurcada en el extremo distal, la postura digitígrada con movimiento independiente de los falanges y la almohadilla digital son adaptaciones funcionales peculiares que aseguran la estabilidad transversal del paso. La anatomía de las piernas traseras les permite descansar sobre el vientre con las rodillas dobladas y los garrones hacia atrás.

La resistencia de los camélidos a condiciones extremas de temperaturas en el ecosistema andino, donde juega un papel importante la latitud de los andes sobre las montañas tropicales cercanas a la línea del Ecuador, produciendo altas temperaturas diurnas y bajas durante la noche, se debe a la presencia de fibra que los aísla del medio ambiente y también a adaptaciones de comportamiento que determinan que los animales de forma natural busquen zonas protegidas y permanezcan agrupados durante la noche (Raggi, 1993).

La eficiencia del sistema digestivo de los camélidos los diferencia de los rumiantes. Taxonómicamente los camélidos y los rumiantes se clasifican en dos subórdenes diferentes: Suborden Tylopoda y Suborden Ruminantia respectivamente. Sus 
características digestivas los convierten en las especies mejor adaptadas para aprovechar la vegetación escasa y fibrosa de los ecosistemas altiplánicos, esto se debe a la selectividad que estos animales realizan en la pradera, al tener un tiempo prolongado de retención de los alimentos en el tracto digestivo, a la mayor frecuencia de contracciones estomacales, ciclos de rumia cortos, amplia relación entre flujo salival, tamaño estomacal y a la presencia de sacos glandulares en el estómago. El aparato bucal de los camélidos presenta labio leporino, que confiere a estos animales una ventaja para asir y recolectar forraje con gran eficiencia. Una particularidad son los incisivos, que se ubican oblicuamente y tienen un crecimiento continuo, semejante al de los roedores. Este tipo de sistema dentario, les permite seguir recolectando forraje eficientemente a pesar del paso de los años, por lo que favorece su longevidad. Además, al realizar la aprehensión de los pastos, realizan un corte que conserva mejor el estrato herbáceo altiplánico (Raggi, 1993).

Otras características comunes de los cuatro camélidos sudamericanos son la presencia de glándulas metatarsianas, organización social polígama, utilización de estercoleros y ovulación inducida con una sola cría.

Como adaptación a las condiciones del Altiplano también debemos destacar que la gestación conlleva un tiempo prolongado de 11 meses, mayor a la de otros mamíferos y de una sola cría permitiendo el nacimiento de un neonato desarrollado; además las crías nacen en el día con el objeto de asegurar una temperatura adecuada. La pubertad en los camélidos domésticos se da al año de vida en las hembras y en los machos se alcanza alrededor de los dos años. La actividad sexual, seguida de ovulación y fertilización, tiene lugar en las hembras a partir de los 12 meses de edad. La fertilidad y las tasas de nacimiento están estrechamente relacionadas con el peso corporal al momento del apareamiento; se ha indicado un peso de 33 kilos como crítico para el éxito reproductivo en animales de un año. Las prácticas de crianza generalmente retardan las cruzas hasta los dos años de edad, tanto en hembras llamas como alpacas (Urquieta, 1993). Los camélidos son considerados como reproductores estacionales, su temporada normal de apareamiento ocurre en los meses más cálidos y húmedos entre agosto y septiembre cuando el forraje es más abundante (Álvarez, 2005). 
Las llamas, alpacas y vicuñas muestran un patrón de apareamiento similar, en el que se distinguen dos fases, una inicial, de cortejo, seguida por la cópula. Durante la primera, el macho persigue e intenta montar a la hembra, prolongándose sólo pocos minutos si la hembra está receptiva. La segunda, la cópula dura entre 30 y 50 minutos y la eyaculación es intrauterina. La duración de la gestación es de alrededor de once meses en las cuatro especies de camélidos. La duración de la gestación en llamas y alpacas varía entre 342 a 350 días. En cautiverio la llama ha llegado a vivir 28 años (Álvarez, 2005).

\section{Procesos de domesticación y situación actual de los camélidos}

En base a los restos arqueológicos y los animales momificados antiguos referidos a la domesticación de la llama y a la alpaca hallados en la Puna de los Andes peruanos (Wing, 1983; Wheeler, 1984, 1995; Bonavia, 1996) localizados entre los 4000 y 4900 msm, se puede deducir que al finalizar el Pleistoceno (Fig. 6), estos espacios geográficos comienzan a poblarse con grupos de cazadores recolectores donde se explotaron y consumieron una gran variedad de recursos animales, entre los que se encontraban los camélidos sudamericanos. Durante el Holoceno medio se produce un incremento en un 83 \% en la población de camélidos. Este cambio pudo darse por la intensificación o incremento en la producción y productividad de este recurso. Algunas regiones presentaron condiciones propicias con presencia de agua y pasturas, convirtiéndose en refugios para las poblaciones animales y humanas que ya se desplazaron de forma oportunista o estacional, habitando esos lugares aprovechando la presencia de poblaciones de camélidos silvestres (Yacobaccio, 2003).

En el Holoceno tardío, cuando aparecen los primeros sitios con viviendas construidas por aglomeración de estructuras de piedras, los camélidos son intensamente utilizados, incrementando su población en un 87 \%; la evidencia zooarqueológica encontrada por Yacobaccio (2003) indica que además de la caza, aparecen formas de manejo de las poblaciones de camélidos.

En un período anterior al Imperio Incaico (siglos XV-XVI) existieron numerosas culturas occidentales extendidas hasta la costa del Pacífico dependientes de alguna forma de los camélidos domésticos y silvestres, que les proporcionaban riqueza y posición 
social, además de ser utilizados para sacrificios religiosos, transporte y medicina. Datos arqueológicos indican que las llamas fueron criadas y utilizadas intensamente por varias culturas de la costa del Pacífico (400-1400 AC) y (550-900 DC) (Shimada \& Shimada, 1985).

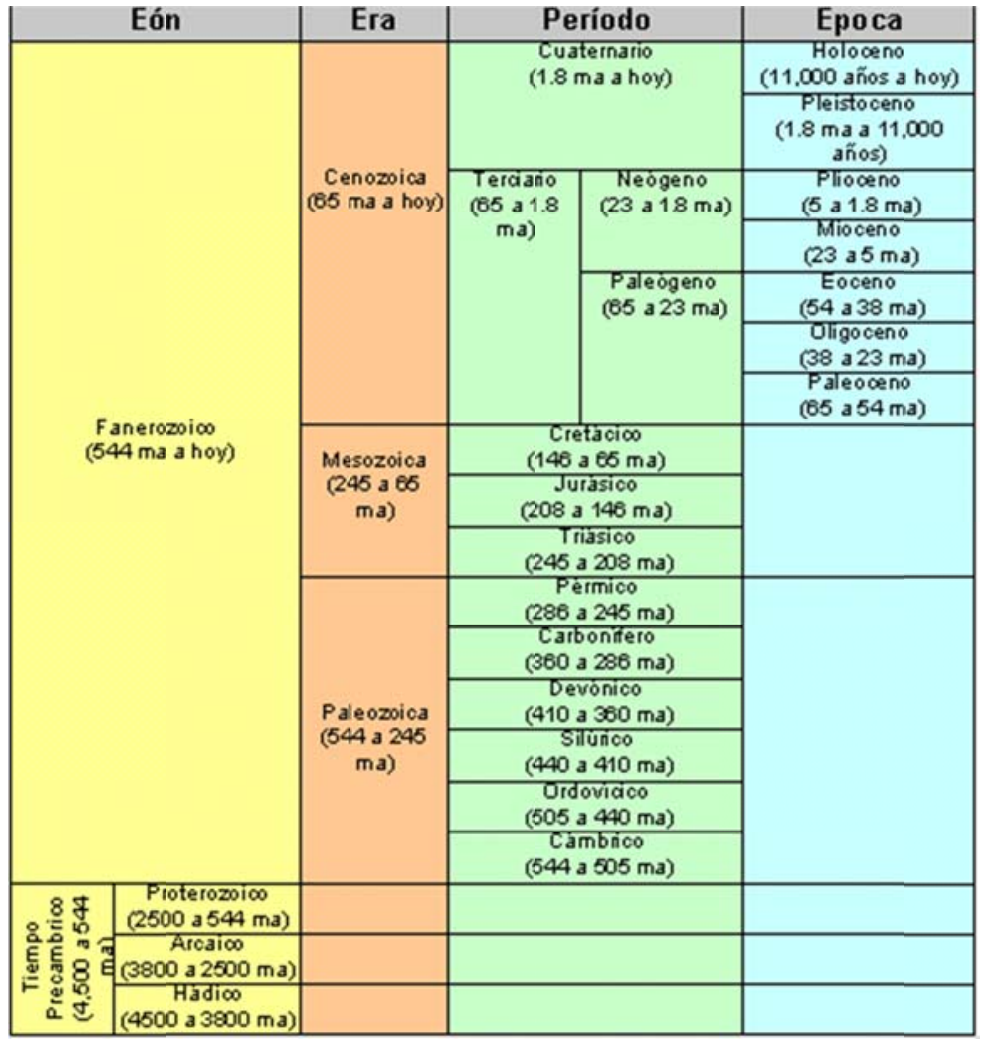

Figura 6. Datación de las eras geológicas y descripción.

El descubrimiento de momias de llamas y alpacas en la zona del Yaral, localizado en el desierto costero árido del Perú a 1000 m sobre el nivel del mar (msnm), está documentado con una datación de 700-1300 años AC. Durante la Cultura Chiribaya (preincaica) se encuentra una primera evidencia sobre la domesticación de los camélidos. La zona se caracteriza por estar cerca del río Osmore con presencia de andenes para la agricultura y evidencias arqueológicas de ser una ciudadela en la que existían zonas para el sacrificio de animales para ser ofrecidos a deidades. Las primeras conclusiones que pueden ser extractadas de estos hallazgos son que parece que llama y alpaca son especies bien separadas en su uso dentro de la sociedad pastoral pre-incaica e incaica y a su vez eran divididos en rebaños de hembras con cría, hembras jóvenes y de jóvenes machos, 
poniendo especial cuidado en seleccionar animales de diversos colores (Summar, 1993). Ya desde ese entonces parece que la alpaca era un animal unido más a la producción de fibra, los primeros repertorios descubiertos relativos a este animal tienen fecha de al menos hace 3000 años. La práctica textil era bien conocida en la sociedad pre-incaica. Por otra parte, la llama se presenta más variable que la alpaca y esto nos explica por sus diferentes funciones: era un animal de carga lo mismo civil que militar, era esquilado por su fibra (en El Yaral, algunas llamas tienen un vellón muy fino) y probablemente servía también para el aprovechamiento de carne. Parece ser que ambas especies eran probablemente usadas en los sacrificios: animales de color puro para el sacrificio de deidades, como por ejemplo llamas blancas al sol, animales castaños rojos a Wiracocha (el dios de la Varas) al comienzo del año agrícola, y animales negros en tiempos de crisis (Salinas, 1998). Fue durante el periodo del Imperio Inca, cuando los camélidos llegaron a su máxima expansión y desarrollo, siendo considerados propiedad del Inca, así como pertenecientes a los centros religiosos, y en algunos casos propiedad de las comunidades e individuos (Summar, 1993).

Durante la conquista española, el Imperio Inca (territorios correspondientes a Perú, Bolivia, sur de Colombia, norte de Chile y noroeste de Argentina en la actualidad) sufrió una reducción drástica de los camélidos, estimada en torno al 90 \% del total junto a una reducción de aproximadamente el 80 \% de la población humana. Se introdujo ganado foráneo, los rebaños nativos fueron rápidamente diezmados y desplazados de la costa y los valles interandinos a las punas de gran altura, donde los animales europeos no prosperaban y que los conquistadores consideraban zonas inhabitables para el hombre y los animales (Wheeler, 1991; Summar, 1993). Durante este período la Iglesia recababa diezmos de la producción del ganado traído de España y prohibió el consumo de carne de camélidos y de cultivos andinos a fin de reforzar la introducción de productos exóticos provenientes de Europa. Por efecto de la conquista y las guerras civiles, se sacrificaron indiscriminadamente cientos de miles de llamas y alpacas, para el abastecimiento de carne y otros usos (Summar, 1993); así el número de camélidos en América, después de haber llegado a su máxima expansión y desarrollo durante la vigencia del Imperio Inca en el que algunos historiadores hablan de un numero entre 30 y 50 millones de animales, declinó hasta una reducción de casi el 90 \% de la población total. Otra causa para la 
reducción de las poblaciones nativas de camélidos y humanas fue la llegada de nuevas enfermedades vehiculizadas por los hombres y animales domésticos europeos como la sarna enfermedad nunca vista antes en estas poblaciones (Bonavia, 1996) y un completo trastorno y abandono del sistema ordenado de manejo incaico.

Además de la reducción en número de estas poblaciones, existen otras dos consecuencias importantes de la conquista Europea: la marginalización geográfica de los animales con la consecuente adaptación a la montañea y la pérdida, si existían, de barreras reproductivas entre las dos especies.

A nivel genético, las consecuencias de la conquista han provocado diversos fenómenos en las poblaciones de camélidos como efectos cuello de botella por la reducción numérica anteriormente comentada. El efecto de deriva genética ha sido seguramente muy fuerte pero no existe ningún medio para cuantificarlo, ni para poder individualizar la cantidad y el tipo de características desaparecidas; además para los animales regresados a la Puna, la selección natural vuelve a tomar la delantera respecto a la artificial, con la consecuente pérdida de la especialización que parecía estar establecida ya en época pre-incaica. Luego, la eficiencia de la ganadería decae completamente y la mezcla entre la llama y la alpaca reduce la divergencia genética que probablemente era más amplia en la fase de la pre-conquista.

Después de la Conquista el progresivo y lento aumento del número de animales alcanzó a 440000 alpacas y aproximadamente un millón de llamas (Summar, 1993). La numerosidad actual es enormemente diferente a la precedente y está en duda que la especie doméstica esté bien consolidada. El sistema de ganadería continúa sin ser especializado en Perú, Bolivia, Argentina y Chile. Actualmente no existe ningún programa de selección en desarrollo en estos países ni para la llama ni para la alpaca.

El interés por la fibra de alpaca empieza a hacerse importante en la industria textil europea a finales del 1700 e inicios del 1800. Sobre la base de la petición industrial, se ha asistido en los últimos decenios a un progresivo aumento de los animales uniformemente blancos respecto a los de color. Estudios actuales hablan de un 80 \% de animales blancos. 
La reducción de la variabilidad ha llevado al nacimiento de Centros de conservación de animales de color.

En base a esta dinámica de los camélidos salvajes y domésticos, es necesario impulsar la caracterización genética de llamas, alpacas, vicuñas y guanacos en Bolivia, Perú, Chile, Argentina. Las especies domésticas muestran una elevada variabilidad de los caracteres externos, debidos a altos índices de primariedad. La misma situación puede observarse en algunas poblaciones de alpaca donde el "efecto de blanqueo" aún no ha llegado. De esta manera es de gran interés determinar la estructura genética y variabilidad genética de las poblaciones de camélidos sudamericanos asociadas a las distintas localidades o regiones donde se encuentran distribuidas estas especies a fin de proponer auténticos programas de mejoramiento genético.

\section{Importancia de los camélidos sudamericanos como recurso animal en Bolivia}

Particularmente en Bolivia, los camélidos sudamericanos son considerados especies de gran valor ecológico por el frágil ecosistema de la zona andina en general y del Altiplano en particular; siendo además una de las actividades de mayor importancia económica y cultural en la región. La población rural de Bolivia está representada por 745.000 familias de las cuales el $51 \%$ de ellas se ubican en el Altiplano entre los departamentos de La Paz, Oruro y Potosí. El 80 \% de sus habitantes viven en situación de pobreza, siendo la agricultura la principal actividad económica. Los ingresos de los productores son un 30 \% más bajo que los ingresos de un hogar marginal urbano. Cerca de 54.000 familias son productoras de camélidos en todo el Altiplano boliviano (Potosí, 22.000 familias, Oruro, 17.000 familias y La Paz 11.000 familias). Aproximadamente, el $30 \%$ de las familias obtienen casi la totalidad de sus ingresos de la producción de camélidos y sus derivados (MACA, 2004). Además, en los últimos años el sistema productivo boliviano ha demostrado importantes avances cualitativos y cuantitativos que le permitieron asimilar nuevas realidades como el libre mercado y la competitividad, e identificar oportunidades económicas para el país; de aproximadamente tres millones de animales se genera una economía de cerca de 50 millones de dólares al año distribuidos en aportes a la producción, al comercio, al empleo y a las exportaciones estando la 
vocación productiva dirigida principalmente a las llamas. Al existir mayor número de llamas en este país, esta especie se constituye en una de las principales fuente de ingresos. La producción de carne es el principal destino de esta especie y los mercados más importantes están en los departamentos de Oruro, La Paz, Cochabamba y Potosí. Existe también producción de excelente fibra con posibilidades de exportación en comunidades de llamas tipo T’hampulli en Ayopaya y Nor - Sur Lípez (Stemmer et al., 2005; Iñiguez et al., 1998). Para su aprovechamiento sin embargo, se deben llevar a cabo programas de manejo y comercialización adecuados.

Otra de las especies domésticas de gran importancia en Bolivia es la alpaca, siendo este país el segundo productor mundial de esta especie. La producción nacional de fibra de alpaca es aproximadamente de 365 Ton., de las cuales el $90 \%$ se destina al mercado nacional. Los departamentos más importantes en la producción de fibra de alpaca son La Paz y Oruro, con el 55 \% y 44 \%, respectivamente. La finura de la fibra de alpaca producida en el país en promedio es de 21 micras; sobresalen las alpacas de la zona de Ulla Ulla, departamento de La Paz, en relación con la fibra de alpaca de la zona de Sajama en el departamento de Oruro (22 micras). Del total de la oferta de fibra de alpaca, se estima que el $25 \%$ es de color blanco, el $63 \%$ de colores enteros y el $12 \%$ manchados. Si bien la industria textil demanda fibra de diferentes colores, hay preferencia por el color blanco y se reconoce un precio de compra en un $35 \%$ mayor con respecto a colores enteros. Esta mayor existencia de colores enteros y manchados reduce significativamente el ingreso económico de los productores.

En cuanto a las vicuñas, desde su inicio hasta el 2007 la captura y esquila de vicuñas en Bolivia ha producido $950 \mathrm{Kg}$ de fibra, generando un ingreso económico hasta el 2007 de 333.421 \$us, cuya ganancia fue repartida en un $90 \%$ como ingreso directo para las 47 comunidades y 14 Ayllus manejadoras de vicuña. El 10 \% restante fue distribuido para el Estado, del cual el 5 \% correspondió a las Prefecturas (La Paz, Oruro y Potosí) y el 5 \% restante al Ministerio de Desarrollo Rural, Agropecuario y Medio Ambiente (Llobet et al., 2003, DGByAP 2007). Es evidente que el manejo de la vicuña en Bolivia necesita de apoyo en la comercialización de la fibra, para poder optar a mayores mercados y mejores precios, incrementando la cantidad y la calidad del producto. De igual forma es necesario 
establecer políticas claras en la repartición de beneficios que deben incluir un porcentaje para el personal técnico y administrativo y para el mantenimiento y reposición de materiales (Shaley, 1999).

En Bolivia, la población de guanaco está restringida a parches de pampa al sureste del departamento de Santa Cruz. Actualmente se encuentran en su mínima expresión bajo iniciativas de protección y conservación de la especie, por lo que esta especie podría convertirse en fuente de valor para las comunidades chaqueñas por la calidad y alto valor comercial de la fibra.

\subsection{Sistemas de producción y manejo de los camélidos sudamericanos en el} Altiplano boliviano

En Bolivia las llamas se manejan y producen en sistemas de producción pequeños y por productores de escasos recursos económicos. Los sistemas explotan la pradera nativa comunitariamente aunque con cargas animales que sobrepasan su capacidad productiva sin que tal desequilibrio haya sido atendido adecuadamente por políticas a nivel nacional, regional y de comunidad, con la consiguiente degradación de las praderas (Alzérreca \& Genin, 1992; Stemmer et al., 2005). Existen arreglos comunitarios que son transmitidos de padres a hijos y que determinan aspectos importantes en el manejo de los rebaños. Así los machos se incluyen en rebaños separados de las hembras para ser pastoreados por la comunidad en lugares alejados, y luego reunidos durante la época de monta que coincide con las lluvias de enero y marzo (Rodríguez \& Quispe, 2007). Los rebaños mixtos incluyen hembras de producción y de reemplazo, y crías y animales de un año sin separación de sexos. Cuando los machos alcanzan entre 12 y 18 meses de edad pueden ser destinados a la producción de carne o seleccionados como futuros reproductores (Wurzinger et al., 2008; Rodríguez \& Quispe, 2007). En otros sistemas extensivos los rebaños mixtos incluyen machos reproductores que permanecen con las hembras durante todo el año (Iñiguez et al., 1998; Wurzinger et al., 2008; Rodríguez \& Quispe, 2007). Otros consisten en desplazar machos reproductores (jañachos) de otras regiones para evitar índices elevados de consanguinidad. También se realiza el cruzamiento dirigido y controlado, control de preñez y separación de ancutas (hembras y machos de 9 a 24 
meses). Después del año y medio, los machos son seleccionados como aptos para la reproducción, si es que tienen las características deseadas por el productor, o se castran (capones) y pastorean con las hembras para posteriormente ser sacrificados para el consumo. El tamaño de un rebaño promedio varía con las zonas de producción fluctuando entre 40-60 llamas en zonas con mayor concentración de personas en las comunidades, p.e. en Ayopaya, hasta 120-180 llamas en zonas con menor concentración y más extensivas, p.e en Sur Lípez o en el Altiplano central occidental (Iñiguez et al., 1998). En contraste, el tamaño del rebaño ovino es muy similar en todas las zonas, fluctuando entre 40-70 animales (Stemmer et al., 2005).

Los rebaños tienen una alta proporción de hembras, al menos el 65 \%, mientras que los machos representan hasta el 35 \% del total de la tropa. Las hembras jóvenes (ancutas) representan aproximadamente el $30 \%$ y hasta un $6 \%$ de ellas son descartados para la reproducción. Esta estructura resulta de la venta y consumo de machos, con mayor frecuencia a partir de los cuatro años de edad (Vargas, 2005). Los sistemas productivos no tienen una naturaleza comercial pero progresivamente parecen orientarse hacia las demandas del mercado como la venta de carne o fibra. Así, los sistemas productivos en Bolivia se caracterizan por la falta de homogeneidad en sus suelos y la cría mixta entre llamas y alpacas. En Ulla Ulla el principal resultado es la producción de fibra de alpaca, que se comercializa a través de una compleja red de intermediarios. En las provincias Pacajes y Sajama, la finalidad del sistema es producir fibra de alpaca y carne de camélidos y ovinos. La crianza mixta permite la complementariedad en el uso de los recursos forrajeros. La fibra es comercializada a través de las organizaciones de los ganaderos mientras que la carne lo es a través de intermediarios. Otras importantes zonas del Altiplano central están dedicadas exclusivamente a la producción de carne de llamas y ovinos. Localidades del sur de Bolivia, como Sud Lípez y Nor Lípez, son productoras de fibra de llama comercializada masivamente desde hace pocos años atrás.

El manejo de las vicuñas en Bolivia es únicamente en silvestría. La organización de las capturas involucra varias comunidades, permitiendo la participación comunitaria donde los recursos son administrados por los actores y los beneficios repartidos de forma equitativa (Sahley, 1999; Rendón 2000; Llobet et al., 2003; DGByAP, 2007), 
incentivando la esquila de la vicuña como un potencial económico para estas comunidades.

\subsubsection{Características de la fibra de los camélidos sudamericanos en Bolivia}

Las explotaciones de camélidos en Bolivia son “naturales”, donde normalmente no existe un esquema de selección artificial. Sin embargo, se puede reconocer la existencia de dos variedades fenotípicas de llamas, Q’hara y T’hampulli. Estos fenotipos tienen carácter hereditario y por ello se han denominado tipos o variedades. Ambos tipos se identifican en el rebaño como fenotipos extremos; sin embargo, existen los intermedios de difícil categorización (Iñiguez et al., 1998). Existen dos poblaciones excepcionales de llamas no conectadas entre sí, con alta frecuencia de animales T’hamphulli. La primera de ellas está ubicada en el Altiplano sur, en Sur Lípez-Potosí, (Iñiguez et al., 1998) con una proporción del 47 \% de llamas T’hamphulli. La segunda población, se localiza en la región cordillerana de la Provincia Ayopaya-Cochabamba, con una frecuencia aun mayor: 89,7 \% de este fenotipo de llamas (Wurzinger et al., 2005; Stemmer et al., 2005). En estas dos poblaciones la frecuencia de animales Q’aras fluctúa entre 8 y $10 \%$, siendo el restod e animales de fenotipo intermedio. En la mayoría de las zonas de producción, la distribución es totalmente opuesta con una proporción de llamas Q’aras que fluctúa entre 65 y 83 \% (Iñiguez et al., 1998).

La raza Q’hara está asociada con los campos de pastoreo de escasos recursos forrajeros; las llamas T'hampulli, por su parte, prefieren praderas próximas a zonas húmedas y que contienen pastos tiernos. La extensión del Altiplano es mayor que los pisos altoandinos, por lo tanto, en llamas existe mayor tendencia a la presencia de Q’haras,especializadas para producción de carne y transporte. Las llamas T’hampulli, especializadas en la producción de fibra, se caracterizan por la presencia de mechones de vellón de fibra gruesa en la frente, ligeramente colgantes. En su textura corporal son un poco más cercanas a las alpacas y las extremidades están cubiertas de fibra fina y gruesa hasta la altura de las pezuñas, tanto en las extremidades anteriores como posteriores. Trabajos realizados en la Estación Experimental de Patacamaya han mostrado que entre las fibras que componen el vellón de llamas, las fibras finas (no meduladas) tienen un menor diámetro (25,5 micras) que las fibras gruesas. Por otro lado, existen escasos 
trabajos que han estimado la variación cuantitativa en relación a los caracteres de crecimiento (Wurzinger et al., 2005) y de calidad de fibra (Stemmer et al., 2005). La magnitud de las estimaciones de heredabilidad para esos caracteres, 0,36 para peso corporal, y 0,33 para diámetro medio de fibras, demuestra un gran potencial para lograr progresos a través de la selección.

La coloración de las llamas presenta una mayor variación que en las alpacas desde el blanco al negro y marrón, pasando por toda la gama de colores intermedios con tendencia a la presencia de manchas de varios colores en un mismo animal (Fig. 7). No existe uniformidad de color, $\mathrm{y}$ a veces se observan llamas puras con coloraciones idénticas al guanaco. Los colores básicos de las llamas son el marrón, negro y blanco, de los cuales el color dominante es el marrón y el negro recesivo. La expresión de los colores negro y marrón se debería al gen dominante C. En presencia del gen recesivo c, los animales serían blancos. Respecto a las tonalidades del color, se plantea todavía deforma hipotética que existirían genes diluidores responsables de la herencia de tonalidades (Lauvergne et al., 2006). El color del vellón es una característica genética multifactorial, controlada por lo menos por ocho series alélicas autosomales, e independientes, con tendencia a una mayor mortalidad de las crías con vellón blanco, frente a las crías con vellones coloreados.
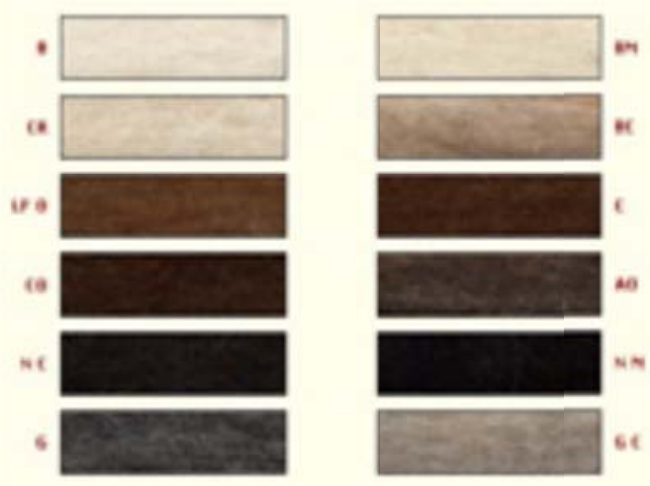

Figura 7. Muestra de 12 colores de los 30 tonos que pueden encontrarse en el vellón de llamas. Tomado de FAO-ICAR, 2004. 
La alpaca ha sido seleccionada para la producción de fibra durante un tiempo de por lo menos 3000 años. Durante este proceso, ha existido un incremento en la longitud de la fibra y modificación de su forma, dando origen a los fenotipos Suri y Huacaya. La primera es angulosa, de menor resistencia al cambio climático, pelo largo que en ocasiones llega hasta el suelo; la población nacional es 32.000 cabezas. La Huacaya tiene una mayor densidad de fibra permitiendo una mayor adaptación al cambio climático y es, por lo general, más robusta que la Suri; el inventario nacional es de 180.000 cabezas. En Bolivia, la producción de fibra es importante con 365 Tm/año provenientes de los sistemas tradicionalmente alpaqueros como Ulla Ulla y Sajama. La finura de la fibra es de 21-22 micras, característica apreciada cuando se comercializa la fibra, producto intermedio o final en los mercados nacionales o de exportación.

La producción de vicuñas en Bolivia presenta una fibra que tiene en promedio en longitud de 3.28 cm y un diámetro de 12.52 micras con un elevado potencial económico (Carpio \& Solari, 1982).

\subsubsection{Características de la carne}

La carne fresca de camélidos se caracteriza por tener un mayor contenido proteínico con relación a otras carnes, siendo esta proporción mayor en llamas, además del bajo nivel de grasas y colesterol (Tabla 1). La cantidad de colesterol por $10 \mathrm{ml}$ de suero sanguíneo en llama alcanza de 5 a $50 \mathrm{mg}$ mientras que en carne de ternera alcanza cantidades de $200 \mathrm{mg}$ y en oveja de $300 \mathrm{mg}$. La carne de llama presenta además concentraciones moderadas de ácidos grasos esenciales como el ácido linolénico y ácido linoleico que son indispensables para el cuerpo humano. La producción estimada de carne de las especies domésticas en Bolivia, para el 2003 fue de 14.973 Tm, de las cuales 13.767 Tm corresponden a llamas y 1.206 Tm a alpacas. El principal productor de carne es el departamento de Oruro con el 55 \%, el departamento de Potosí produce el 24 \% y La Paz el 17 \%. Se estima que el 75 \% de la carne es destinada a la venta (MACA, 2003).

Por su hábitat las llamas están sujetas a pocas enfermedades, que son por lo general controlables lo que permite plantear una producción de carne de llama orgánica (MACA, 
2004). Es importante la producción de carne para alcanzar el mercado nacional e internacional.

Tabla 1. Composición química (\%) de la carne de cinco especies animales. Fuente: MACA, 2004.

Especies Proteínas Grasa Cenizas Humedad

\begin{tabular}{rrrrr}
\hline Llama & 24.82 & 3.69 & 1.41 & 69.17 \\
Alpaca & 21.88 & 5.13 & 1.30 & 70.80 \\
Vaca & 21.01 & 4.84 & 0.91 & 72.72 \\
Oveja & 18.91 & 6.53 & 2.16 & 72.74 \\
Pollo & 20.65 & 4.85 & 1.25 & 73.80 \\
\hline
\end{tabular}

\subsubsection{Características de la piel y cuero}

Los camélidos poseen una piel peculiar por su estructura de colágeno muy compacta que le confiere alta elasticidad (MACA, 2004). Se observan tres zonas diferenciadas: el cuello, es la parte más gruesa y mejor estructurada, luego la doble T que está constituida por las cuatro extremidades unidas por la parte dorsal y lumbar central, es homogénea en grosor, siendo la segunda en calidad y finalmente las faldas, siendo éstas las partes más delgadas que corresponden a la fracción de las costillas y el vientre del animal. Por esta estructura particular, la piel tiene una alta versatilidad para la producción de chaquetas, botas, bolsas de viaje, maletas, etc.

La producción media anual de pieles de llama y alpaca es 434.000 unidades en Bolivia. Sólo el 20 \% de esta producción es utilizada por la industria nacional, el 25 \% se exporta legal e ilegalmente a Chile y Perú, y el resto es mal utilizado por la población rural o simplemente es desperdiciada. Sin embargo, en los últimos años la demanda de piel de camélidos ha aumentado demostrando que el destino principal además del mercado nacional es el mercado de exportación, aunque la industria se encuentra aún en ciernes. 


\section{Aplicación de la genética de poblaciones en el estudio de camélidos sudamericanos}

El estudio a nivel genético de los camélidos sudamericanos ha permitido dilucidar en algunos casos las relaciones filogenéticas, describiendo las diferencias y similitudes encontradas entre sus miembros, también se utilizó en la descripción y discriminación de subespecies en el caso de camélidos salvajes y en la caracterización genética y procedencia genética de llamas y alpacas. Recientemente los estudios genéticos también se han centrado en la descripción de la variabilidad genética de poblaciones de vicuñas y guanacos que fueron afectadas por la caza indiscriminada y por último en el análisis de especies bajo manejo.

Se han desarrollado diversos marcadores moleculares para el estudio genético de camélidos sudamericanos entre los que se destacan históricamente, el uso de isoenzimas, secuencias de ADNmt y marcadores microsatélites. Debido a la tasa de mutación y polimorfismo elevada se han descrito alrededor de 80 marcadores moleculares microsatélites para la familia Camelidae, muchos de ellos con alelos compartidos entre especies cercanas, aunque con diferentes en frecuencias y tamaño de productos. En general todos ellos se han utilizado para el estudio de la filogenia, discriminación sobre el origen de una determinada especie, domesticación, diversidad y estructura poblacional (Vidal-Rioja et al., 1994; Lang et al., 1996; Penedo et al., 1998; 1999a, 1999b; Sarno et al., 2000).

El análisis del ADN nuclear y mitocondrial tiene importantes aplicaciones tales como el análisis de poblaciones usando polimorfismos genéticos y frecuencias genéticas, la cuantificación indirecta de la consanguinidad en una población donde las relaciones de parentesco se desconocen y la relación entre marcadores genéticos y caracteres de producción, de resistencia a enfermedades y de adaptación.

El ADNmt es considerado una fuente adicional de variación genética entre líneas dentro de una raza o población y puede permitir la cuantificación de fuentes importantes de variación genética extranuclear. El ADN mitocondrial es importante también para estimar la distancia genética entre poblaciones. 


\subsection{Relaciones filogenéticas}

El estudio genético de la familia Camelidae mediante diferentes marcadores demostró relaciones genéticas cercanas. Por ejemplo, todas las especies presentan un cariotipo de 2n=74 (Taylor et al., 1968), permitiendo procesos de hibridización dando como resultado descendencia fértil (Skidmore et al., 2001).

El análisis de la región control del ADNmt reveló que esta región se extiende 1060 pb e incluye tres bloques de secuencias conservadas, entre las cuales se encuentra un segmento de 337 pb con 10 sitios polimórficos, útiles para el análisis de variabilidad genética (Maté et al., 2004). Además, utilizando secuencias completas del gen del citocromo $b$, se observó que tanto vicuñas como guanacos son grupos recíprocamente monofiléticos, con respecto a las especies domesticadas llamas y alpacas. El análisis reveló una hibridización direccional apoyando la hipótesis de que guanacos dieron origen a llamas y vicuñas a las alpacas (Marín et al., 2007b).

Estudios realizados utilizando marcadores moleculares, principalmente en base al análisis del ADNmt (el citocromo $b$ y la región D-loop), revelan niveles altos de hibridación entre las especies domésticas de camélidos sudamericanos (Marín et al., 2007a). Stanley et al. (1994), realizando el estudio genético del origen de los camélidos sudamericanos en base al análisis del ADNmt, muestraron la separación en dos grandes grupos, el primero representado por guanaco y el segundo por la vicuña. Los camélidos domésticos, se encuentran en ambos grupos: un alto porcentaje de llamas que presentarían un haplotipo común al guanaco mientras que el $73 \%$ de las alpacas analizadas se encontrarían dentro el grupo de los guanacos, lo que sugiere que sólo un 27 \% de alpacas no habría sufrido ninguna hibridación.

Kadwell et al. (2001) describe, mediante el estudio de marcadores mitocondriales y microsatélites, el origen de llamas y alpacas a partir de sus antecesores silvestres, que se dividen en dos grandes grupos, guanacos y vicuñas. Los camélidos domésticos se encuentran en ambos grupos, las llamas comparten haplotipos similares con los guanacos, y sólo el 19 \% de las alpacas se encuentran dentro el grupo de las vicuñas. Los resultados con cuatro microsatélites muestran que las frecuencias alélicas de los camélidos 
domésticos se encuentran distribuidos entre los dos grupos de los camélidos silvestres, sólo dos marcadores mostraron alelos privados de cada especie silvestre.

\subsection{Resolución de incertidumbres taxonómicas}

La clasificación taxonómica de guanacos según sus rasgos fenotípicos diferencia a cuatro subespecies, L. g. cacsilensis, L. g. guanicoe, L. g. huanacus y L. g. voglii, las últimas consideradas como las más amenazadas y sobre las cuales se realizan planes de manejo y conservación en países como Argentina (González et al., 2006). Un estudio de secuenciación del citocromo $b$ y parte de la región D-loop, agrupó a las cuatro subespecies de guanacos en dos únicas subespecies L. g. cacsilensis y L. g. guanicoe (Marín et al., 2008). Este estudio abre nuevas posibilidades en el manejo de la especie, debido a que las anteriormente subespecies amenazadas comparten la variabilidad genética y pertenecen a la subespecie $L$. g. guanicoe, siendo factible el traslado de individuos con el objetivo de incrementar la variabilidad genética en poblaciones con pocos individuos como es el caso de L.g.voglii en territorios de Bolivia y Paraguay.

Por otro lado, en vicuñas se describieron dos subespecies geográficas, $V$. $v$. mensalis como la especie norteña y $V$. $v$. vicugna como la especie más austral en su rango de distribución. Esta clasificación fue confirmada en base a los estudios genéticos de Sarno et al. (2004) y Marín et al. (2007a, 2007b), definiendo además la distribución geográfica de ambas subespecies, siendo una más austral y otra más meridional, encontrándose ambas en sólo dos países, Chile y Bolivia. Es necesario destacar que en Chile $V$. $v$. vigugna representa un $10 \%$ del total de vicuñas, mientras que en Bolivia ambas especies se encuentran representadas en proporciones similares (Sarno et al., 2004). Se han descrito haplotipos de ADNmt específicos para ambas subespecies y alelos privados en marcadores microsatélites, permitiendo de esta manera discriminar ambas subespecies a partir de análisis genéticos (Sarno et al., 2004).

\subsection{Diversidad genética de poblaciones de camélidos sudamericanos}

Al presente se han realizado análisis de diversidad genética en poblaciones de camélidos domésticos y salvajes de países vecinos. Así, se analizaron y compararon los 
valores de diversidad genética para estimar la pérdida de variación genética por la caza intensiva y la reducción de hábitat en guanacos criados en semicautiverio para la obtención de fibra en Argentina (Maté et al., 2005), encontrando una alta diversidad genética $(\mathrm{He}=0.69)$. Sarnó et al. (2001), también en poblaciones de guanacos continentales e insulares, determinó que la mayor diversidad está en los primeros, como ocurre en la mayoría de los mamíferos continentales. Análisis de poblaciones recuperadas de vicuñas de Bolivia y Chile, con marcadores microsatélites, revelaron niveles de heterocigosis reducidos $(0,62)$ (Sarno et al., 2004). El valor más alto de diversidad genética en vicuñas que registra la literatura, según el análisis de marcadores microsatélites, se identifica en la subespecie $V . v$. mensalis, según el estudio de Sarno et al. (2004). Sin embargo los datos de diversidad genética en el uso de marcadores de ADNmt e isoenzimático muestran que la subespecie $V$. v. vigugna es la más variable en su rango de distribución (Marín et al., 2007a, Sarno et al., 2004, Norabuena \& Paredes, 2003).

A nivel isoenzimático las poblaciones de vicuñas de Chile de la subespecie $V . v$. mensalis presentan un polimorfismo de $17.8 \%$ con un nivel de heterocigosis de 0.078 , en contraste con vicuñas de la subespecie $V$. $v$. vicugna cuyos valores de polimorfismo y heterocigosis se estimaron en 14.3 \% y 0.045 respectivamente (Norabuena \& Paredes, 2003).

El análisis de seis loci microsatélite derivados de Lama glama en una población de 25 llamas y dos poblaciones de guanacos de 29 y 17 animales en Argentina (Bustamante et al., 2002) mostró valores importantes de diversidad alélica en el total de loci analizados en llamas (44) y guanacos (54). Además se encontraron alelos privados en ambas especies. Posteriormente, los mismos autores en el 2006, realizaron un estudio de análisis de diversidad genética en tres poblaciones de llamas del noreste argentino, que se originaron a partir de una sola población. Se encontraron niveles altos de diversidad alélica y heterocigosis para el total de loci analizados y la presencia de 44 alelos privados lo que demuestra un manejo más adecuado de la especie en estos planteles. 
- Trabajo 1: Barreta J, Gutiérrez-Gil B, Iñiguez V, Romero, F, Saavedra V, Chiri R, Rodríguez T, Arranz JJ. Analysis of genetic diversity in Bolivian llama populations using microsatellites. Journal of Animal Breeding and Genetics. doi:10.1111/jbg.12009. (En prensa)

- Trabajo 2: Barreta J, Iñiguez V, Saavedra V, Romero, F, Callisaya AM, Echalar, J, Gutiérrez-Gil B, Arranz JJ. (2012). Genetic diversity and population structure of Bolivian alpacas. Small Ruminant Research, 105, (1-3): 97-104.

- Trabajo 3: Barreta J, Gutiérrez-Gil B, Iñiguez V, Saavedra V, Chiri R, Latorre E, Arranz JJ. Analysis of mitochondrial DNA in Bolivian llama, alpaca and vicuna populations: a contribution to the phylogeny of the South American camelids. Animal Genetics. doi: 10.1111/j.1365-2052.2012.02376.x. (En prensa).

- Trabajo 4: Barreta J, Iñíguez V, Sarno, RJ., Gutiérrez-Gil B, Arranz JJ. (2011). Mitochondrial DNA (mtDNA) genetic Diversity of Vicugna vicugna mensalis in Bolivia. En: Fibre production in South American camelids and other fibre animals (pp. 123-130). Wageningen Academic Publishers. ISBN 978-90-8686-727-1.

- RESUMEN DE RESULTADOS Y DISCUSIÓN GENERAL

\section{METODOLOGÍA, RESULTADOS Y DISCUSIÓN}





\section{ANALYSIS OF GENETIC DIVERSITY IN BOLIVIAN LLAMA POPULATIONS USING MICROSATELLITES.}

Barreta J, Gutiérrez-Gil B, Iñiguez V, Romero, F, Saavedra V, Chiri R, Rodríguez T, Arranz JJ.

Journal of Animal Breeding and Genetics. doi:10.1111/jbg.12009. (En prensa). 

ORIGINAL ARTICLE

\title{
Analysis of genetic diversity in Bolivian llama populations using microsatellites
}

\author{
J. Barreta ${ }^{1,2 \dagger}$, B. Gutiérrez-Gil ${ }^{1 \dagger}$, V. Iñiguez ${ }^{2}$, F. Romero $^{2}$, V. Saavedra ${ }^{3,4}$, R. Chiri $^{3}$, T. Rodríguez $^{5}$ \& \\ J. J. Arranz ${ }^{1}$ * \\ 1 Dpto. Produccion Animal, Universidad de Leon, Leon, Spain \\ 2 Instituto de Biologia Molecular y Biotecnologia, UMSA, La Paz, Bolivia \\ 3 Centro Experimental Agropecuario Condoriri, Facultad de Ciencias Agrarias y Veterinarias, Universidad Técnica de Oruro, Oruro, Bolivia \\ 4 Banco de Germoplasma BANCAMEL-INIAF, Oruro, Bolivia \\ 5 Facultad de Agronomía, UMSA, La Paz, Bolivia
}

\begin{abstract}
Keywords
Genetic diversity; llama; microsatellite; population structure.

\section{${ }^{*}$ Correspondence}

Juan-José Arranz, Dpto. Producción Animal, Facultad de Veterinaria, Universidad de León, 24071 León, Spain. Tel: +34 987 291470;

Fax: +34 987 291311; E-mail: jjarrs@unileon.es

${ }^{\dagger}$ These two authors contributed equally to this work.
\end{abstract}

Received: 11 April 2012;

accepted: 27 August 2012

\section{Summary}

South American camelids (SACs) have a major role in the maintenance and potential future of rural Andean human populations. More than $60 \%$ of the 3.7 million llamas living worldwide are found in Bolivia. Due to the lack of studies focusing on genetic diversity in Bolivian llamas, this analysis investigates both the genetic diversity and structure of 12 regional groups of llamas that span the greater part of the range of distribution for this species in Bolivia. The analysis of 42 microsatellite markers in the considered regional groups showed that, in general, there were high levels of polymorphism (a total of 506 detected alleles; average PIC across per marker: 0.66), which are comparable with those reported for other populations of domestic SACs. The estimated diversity parameters indicated that there was high intrapopulational genetic variation (average number of alleles and average expected heterozygosity per marker: 12.04 and 0.68 , respectively) and weak genetic differentiation among populations $\left(F_{\text {ST }}\right.$ range: 0.003-0.052). In agreement with these estimates, Bolivian llamas showed a weak genetic structure and an intense gene flow between all the studied regional groups, which is due to the exchange of reproductive males between the different flocks. Interestingly, the groups for which the largest pairwise $F_{\mathrm{ST}}$ estimates were observed, Sud Lípez and Nor Lípez, showed a certain level of genetic differentiation that is probably due to the pattern of geographic isolation and limited communication infrastructures of these southern localities. Overall, the population parameters reported here may serve as a reference when establishing conservation policies that address Bolivian llama populations.

\section{Introduction}

Breeding and exploitation of South American camelids (SACs) are important in the maintenance and future economic potential of rural Andean populations as these species represent a valuable economic resource for high-quality fine-fibre textiles, leather and other industries. In addition to the cultural importance of the domestic species because of their traditional use in rites and celebrations (Webster 1973), the meat derived from llamas and alpacas, which has traditionally been a rich source of protein for self-sufficient local breeders, is now being marketed. This trend reflects a growing demand for this meat and has significant potential for international trade. 
In terms of size, the llama is the largest species of the domestic SACs and resembles its ancestor, the guanaco, in almost all aspects of morphology and behaviour (Wheeler 1995). Similar to the guanaco, the llama has adapted to a wide range of environments, as its presence has been recorded at high elevations, valleys and coastal sites (Mengoni Goñalons 2008). It is found in Bolivia, Peru, northern and central Chile, north-west Argentina and Ecuador. Two types of llamas are traditionally recognized: K'ara and T'hampulli, although some authors suggest also an intermediate type (Iñiguez et al. 1998). The T'hampulli type has fibre on its face and down its legs, whereas the K'ara type has a clean face and no hair on its legs (Wurzinger et al. 2005). The T'hampulli type is bred for fibre and meat production, while the $\mathrm{K}^{\prime}$ ara type is reared primarily for the self-sufficiency of the breeders' families and is still used as pack animal (Stemmer et al. 2005).

The production system for Bolivian llamas is agropastoral. The largest proportion of the products is directly consumed by the household, and only a small proportion is sold in local markets. In recent years, the llama population has remained relatively stable in Bolivia. More than $60 \%$ of the 3.7 million specimens worldwide are found in this country (INE 2008), and more than 54000 rural poor families in Bolivia are dedicated to llama husbandry as part of their livelihood. The species distribution is wide, extending along the northern, central and southern highland regions of the Bolivian plateau, where they are subjected to extreme climate fluctuations that are characterized by strong UV radiation and long periods of frost and drought. Breeding systems are traditional and are based on the free grazing of extensive meadows. The llama diet is mainly composed of grasses and tolares (Festuca sp.) of low nutritional quality (Iñiguez et al. 1998). Llama populations display a considerable amount of phenotypic variation, which is reflected in several parameters, such as body conformation, fibre length and fleece colour (Iñiguez et al. 1998).

In Bolivia, genetic studies on the llama are scarce and are basically limited to the analysis of the quantitative parameters of growth- and fibre-related traits (Stemmer et al. 2005; Wurzinger et al. 2005). In recent years, microsatellite markers have proven to be useful polymorphic markers for the analysis of genetic variability within and between animal populations, and an increasing number of genetic studies have been reported in domestic SAC species. Hence, a high level of genetic diversity has been reported in Argentinean llamas (Bustamante et al. 2002, 2006) and in both Peruvian and Bolivian alpacas (Paredes et al.
2012; Barreta et al. 2012). Although based on a smaller number of studies, using microsatellite markers, the guanaco and vicuna appear to have lower heterozygosity and allelic richness compared with the domestic species (Penedo et al. 1998b; Sarno et al. 2004; Maté et al. 2005).

Measuring the genetic diversity and genetic distances within and between populations provides useful parameters to identify genetic stocks that may display improved viability and productivity (Hammond 1994) and to detect rare alleles that indicate the presence of unique genetic variants and change in domestic populations due to genetic drift, selection and/or hybridization (Luikart et al. 2001). The lack of studies focusing on genetic diversity in Bolivian llamas compelled us to examine a set of 42 microsatellites to investigate the genetic diversity of 12 regional groups of llamas spanning most of the range of distribution of this species in Bolivia. The information generated has also been used to infer recent demographic relationships between the different sampling areas and to assess, for the first time, the genetic structure and the level of admixture in Bolivian llama populations. As a complementary objective of the study, we have estimated genetic distances among the established varieties of this species, K'hara, Intermediate and T'hampulli. This analysis was performed with the aim of assessing whether the phenotypic differences observed for fibre- and meat-related traits in these varieties can be detected based on genetic differentiation.

\section{Materials and methods}

\section{Sample collection and PCR amplification}

Hair and blood samples were obtained from 394 llamas from 24 different localities, covering the entire wide geographical range of distribution for this species in Bolivia, in the western Andean region of the country (Figure 1). These 24 localities were grouped into 12 sampled regional groups, seven of which involved more than two localities. The grouping criteria were the geographic proximity and similar management system, including the exchange of animals based on existing community agreements that determine important aspects in the management of the flocks. The maximum geographical distance found within a defined regional group was $239 \mathrm{~km}$ in the Sajama group (between Carangas and Turco). The range of geographical distances estimated between the 12 regional groups considered (taking an intermediate position for the groups including more than one local- 
ity) ranged between $175.5 \mathrm{~km}$ (between the Ayopaya and Bolívar) and $336 \mathrm{~km}$ (Ingavi and Sur Carangas groups). The following names (number of samples in the study in brackets) that are based on one of the localities included in the corresponding group will be used to refer to the 12 regional groups studied here: Ayopaya $(\mathrm{n}=36)$; Bolivar $(\mathrm{n}=29)$; Pacajes $(\mathrm{n}=39)$; Sajama $(\mathrm{n}=49)$; Sur Carangas $(\mathrm{n}=69)$; Franz Tamayo $(\mathrm{n}=39)$; J. Manuel Pando $(\mathrm{n}=30)$; Ingavi $(\mathrm{n}=25)$; Sud Lípez $(\mathrm{n}=19)$; Nor Lípez $(\mathrm{n}=25)$; Quijarro $(\mathrm{n}=20)$; and Nor Cinti $(\mathrm{n}=14)$ (Figure 1 and Table S1 shows all of the localities that were included in each of these regional groups). A total of 183 of these samples distributed across the 12 regional groups had phenotypic information available, having been classified as the K'ara, T'hampulli or Intermediate types.

Genomic DNA was isolated using a procedure appropriate for the source of each sample. DNA extraction from hair samples was performed using a modified protocol based on the method described by Woodward et al. (1994). The DNA extraction protocol from blood was adapted from that described by Doyle E Doyle (1987).

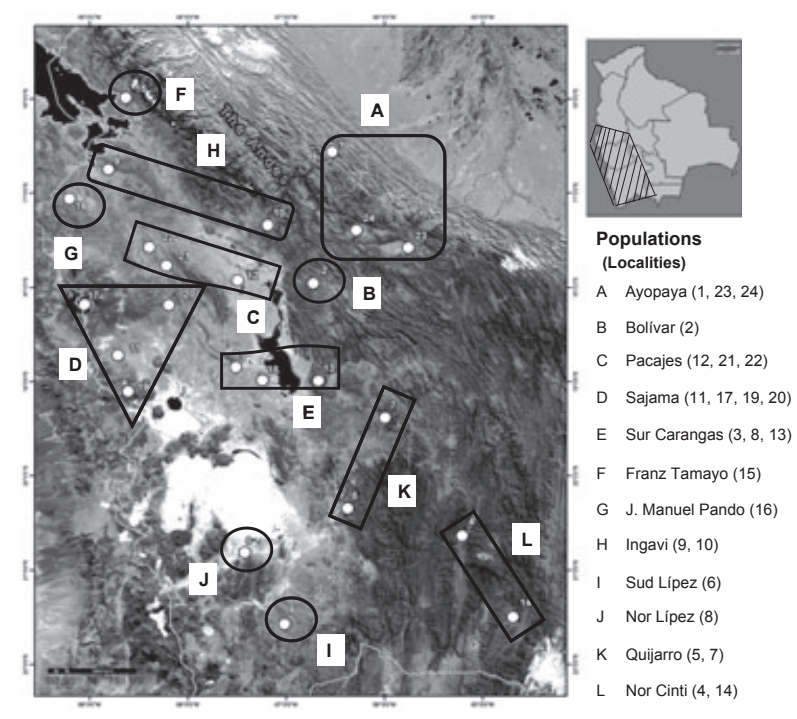

Figure 1 Geographical locations of the 12 Bolivian llama regional groups that were considered in this work. White circles show the 24 sampling localities: 1-Ayopaya, 2-Bolívar, 3-Sud Carangas, 4-Nor Cinti, 5Quijarro, 6-Sud Lípez, 7-Tomás Frias, 8-Nor Lípez, 9-Ingavi, 10-Yawaroco, 11-Carangas, 12-Nor Carangas, 13-Avaroa, 14-Tarija, 15-Franz Tamayo, 16-J. Manuel Pando, 17-Sajama, 18-Orinoca, 19-La Rivera, 20-Turco, 21-San Pedro de Totora, 22-Pacajes, 23-Arani, 24-Quillacollo. These localities were grouped into 12 different regional groups (A to $L$ ) as represented by solid lines.
Forty-two microsatellite markers were chosen from previous genetic diversity studies that focused on the domestic llama, the domestic alpaca, the guanaco and the camel (Camelus dromedarius). Eleven of the 42 markers are included in the FAO/ISAG recommended list of markers for genetic diversity and parentage test in camelid species. Markers with similar PCR conditions were co-amplified using multiplex PCR, and the fluorescent labelling of the forward primers allowed for the design of multi-loading panels, as indicated in Table S2. After co-amplification, the PCR products of each multi-loading panel were separated by capillary electrophoresis in an automatic ABI3130xl DNA Sequencer (Applied Biosystems, Foster City, CA, USA). The results of the capillary electrophoresis were read directly using the GENEMAPPER v.4.0 software (Applied Biosystems).

\section{Statistical analyses}

The genetic diversity was analysed to calculate the number of alleles, to identify private alleles for each group studied and to estimate the unbiased expected and observed heterozygosity (He and Ho, respectively) using the GENETIX 4.05 software (http://kimura. univ-montp2.fr/genetix/). The distribution of genetic variability between regional groups was studied by analysing the Wright $F$-statistics as described by Weir \& Cockerham (1984). Possible 'outlier loci' were detected based on the $F_{\mathrm{ST}}$ and $F_{\mathrm{IS}}$ behaviour observed for each marker in the entire population following the indications provided by Luikart et al. (2003). The polymorphism information content (PIC) was estimated with MOLKIN 2.0 (http://www.ucm.es/info/ prodanim/html/JP_Web.htm). To test whether the allelic richness values were a consequence of the different number of samples per regional group, the rarefaction method in this software was applied to calculate the mean number of alleles observed per group and the mean allelic richness. The significance levels were assessed by conducting 10000 permutations. Deviations from Hardy-Weinberg (HW) equilibrium were tested using Fisher's exact test with the program GENEPOP v3.3 (http://genepop.curtin.edu.au/). The pairwise linkage disequilibrium (LD) between markers was estimated using ARLEQUIN v3.5 (http://cmpg. unibe.ch/software/arlequin35/). To take into account multiple testing in this LD analysis, a sequential Bonferroni correction was used to maintain type I probability error at $\alpha=0.05$.

The level of genetic differentiation within and among groups was also calculated by performing both AMOVA and SAMOVA tests using ARLEQUiN v3.5 (http:// 
cmpg.unibe.ch/software/arlequin35/) and SAMova v1.0 (http://cmpg.unibe.ch/software/samova/). Factorial correspondence analysis was performed with the GENETIX v4.05 software (http://kimura.univ-montp2. fr/genetix/) to further assess the genetic relationships between zones studied. The number of populations underlying the analysed regional groups and the proportion of mixed ancestry among groups were assessed using a clustering analysis based on the 'admixture' model implemented in the structure v.2.3 software (http://pritch.bsd.uchicago.edu/structure. html). This analysis was performed after eliminating outlier loci detected based on the behaviour of individual $F_{\text {ST }}$ estimates (Luikart et al. 2003). Simulations were performed using a burn-in period of 50000 rounds followed by 500000 MCMC iterations. Independent runs of $K$ were performed from 1 to 14 clusters and were repeated 10 times to check the consistency of the results. To choose the optimal K, the posterior probability was calculated for each value of $K$ using the mean estimated log-likelihood of $K$, $\mathrm{L}(\mathrm{K})$. Following Evanno et al. (2005), we also calculated delta $K(\Delta K)$ for each tested value of $K$ (except for the maximum $K$ tested), which is an ad hoc statistic that is based on the second derivative of the likelihood function with respect to $K$, L" $(K)$ (Evanno et al. 2005). Graphic representations of these statistics were obtained using the web-based STRUCTURE HARVESTER SOftware v0.6.8 (http://taylor0.biology.ucla edu/structureHarvester/). We also performed a population structure analysis with a different Bayesian clustering program assuming a spatial model with the BAPS v5.3 software (http://web.abo.fi/fak/mnf//mate/ jc/software/baps.html). All of the analyses described above were also performed using the subset of 183 animals that had available phenotypic information (K'hara, T'hampulli and Intermediate).

\section{Results}

\section{Genetic diversity at microsatellite loci}

All of the 42 microsatellite loci were polymorphic in the 12 llama regional groups that were analysed with the exception of marker CMS25 in both Nor Lípez and Nor Cinti and marker PCTD17 in Sud Lípez. A total of 506 different alleles were observed in the entire llama population. The number of alleles per locus ranged from 3 for PCTD 17 to 31 for LCA66, with the average value across markers being 12.04. The expected heterozygosity ranged from 0.141 for CMS25 to 0.901 for YWLL08 (Table S3). The estimated PIC values for the analysed markers ranged from 0.139 (CMS25) to
0.0.893 (YWLL08), and we detected a frequency of null alleles in the total population ranging from 0.015 for LCA18 to 0.497 for P194 (Table S3).

For the entire population and accounting for multiple testing (42 markers and 12 regional groups), 20 of the 42 analysed loci were identified to be in HW disequilibrium $(p<0.0001)$ (Table S3). The multi-locus HW test performed for the global population also suggested that the whole llama population studied was in HW disequilibrium $(\mathrm{p}<0.001)$. Upon examining individual groups, the HW equilibrium tests showed an average of 1.8 regional groups in HW disequilibrium per marker. Based on the criteria required for the markers to be analysed in the population structure analysis, those markers showing deviation from the HW equilibrium in at least five studied regional groups were discarded from further analyses (P194, LCA63, YWLL43 and P57).

After applying the Bonferroni correction to take into account all the marker pairs analysed, no significant LD (experimentwise level $\alpha=0.05$; nominal p-value $<0.00007$ ) between markers was found in the global population. The largest LD level, although not significant, was found for the marker pairs YWLL29-YWLL36 ( $\mathrm{p}=0.00057)$ and LCA68-LCA77 $(\mathrm{p}=0.0029)$, although their LD estimates were not significant.

Upon examining the 38 remaining markers in the individual groups after the HW equilibrium control, the largest mean number of alleles per locus was observed in Sajama (8.8) and the lowest number of alleles was observed in Sud Lípez (5.4) ((Table 1). The allelic richness obtained after sample size correction supported the initial diversity estimations, with Sajama and Sud Lípez showing the highest (5.5) and lowest (4.5) values for this parameter, respectively (Table 1). The 12 regional groups under study exhibited He values ranging from 0.609 (Sud Lípez) to 0.673 (Pacajes) and Ho values ranging from 0.585 (Nor Lípez) to 0.656 (Quijarro).

The overall $F_{\text {Is }}$ value estimated for the complete set of 12 regional groups was 0.08636 ( $\mathrm{p} \ll 0.001$ ). Nine of the regional groups showed significant inbreeding coefficients that were greater than zero. The locality sets showing the largest $F_{\text {Is }}$ estimates, all of them being highly significant $(p<0.001)$, were Franz Tamayo $\left(F_{\text {IS }}=0.119\right)$, Ayopaya $\left(F_{\text {IS }}=0.105\right)$ and Ingavi $\left(F_{\text {IS }}=0.105\right)$ and were associated with highly significant deviations from the HW equilibrium ( $p<0.0001)$, which suggests a heterozygosity deficit for these groups. A total of 70 private alleles, which are alleles observed in a single regional group, were found. The Franz Tamayo 
Table 1 Estimated genetic variability parameters based on the analysis of 42 microsatellite markers for the 12 regional groups of Bolivian llamas considered in this study

\begin{tabular}{llllllll}
\hline Group & $\mathrm{n} 1$ & $\mathrm{H}$ 2 & He3 & MNA4 & AR5 & pA6 & $F_{\text {IS }}$ \\
\hline Ayopaya & 36 & $0.596 \pm 0.200$ & $0.665 \pm 0.198$ & 7.5 & 5.4 & 6 & $0.105^{* * *}$ \\
Bolivar & 29 & $0.625 \pm 0.236$ & $0.640 \pm 0.231$ & 7.2 & 5.2 & 3 & 0.024 \\
Pacajes & 39 & $0.616 \pm 0.200$ & $0.673 \pm 0.204$ & 7.7 & 5.4 & 6 & $0.084^{* * *}$ \\
Sajama & 49 & $0.619 \pm 0.209$ & $0.664 \pm 0.205$ & 8.8 & 5.5 & 9 & $0.068^{* * *}$ \\
Sur Carangas & 69 & $0.607 \pm 0.222$ & $0.657 \pm 0.222$ & 8.7 & 5.4 & 8 & $0.077^{* * *}$ \\
Franz Tamayo & 39 & $0.589 \pm 0.198$ & $0.668 \pm 0.199$ & 7.9 & 5.4 & 12 & $0.119^{* * *}$ \\
J. Manuel Pando & 30 & $0.618 \pm 0.220$ & $0.659 \pm 0.211$ & 7.0 & 5.2 & 4 & $0.062^{* * *}$ \\
Ingavi & 25 & $0.602 \pm 0.203$ & $0.672 \pm 0.197$ & 7.4 & 5.5 & 6 & $0.105^{* * *}$ \\
Sud Lípez & 19 & $0.595 \pm 0.249$ & $0.609 \pm 0.224$ & 5.4 & 4.5 & 4 & 0.024 \\
Nor Lípez & 25 & $0.585 \pm 0.256$ & $0.629 \pm 0.243$ & 6.3 & 5.0 & 6 & $0.071^{* * *}$ \\
Quijarro & 20 & $0.656 \pm 0.244$ & $0.665 \pm 0.221$ & 6.4 & 5.2 & 4 & 0.014 \\
Nor Cinti & 14 & $0.606 \pm 0.251$ & $0.647 \pm 0.218$ & 5.5 & 5.0 & 2 & $0.065^{* *}$ \\
\hline
\end{tabular}

${ }^{1} \mathrm{n}$ : sample size.

${ }^{2} \mathrm{Ho}$ : average observed heterozygosity ( $\pm \mathrm{SD}$ ).

${ }^{3} \mathrm{He}$ : average expected heterozygosity (ISD).

${ }^{4} \mathrm{MNA}$ : mean number of alleles.

${ }^{5}$ AR: allelic richness.

${ }^{6} \mathrm{pA}$ : number of private alleles.

${ }^{7} F_{\text {IS: }}$ estimates and significance per population across the 42 loci. $* p<0.05 ; * * p<0.01$; $* * * p<0.001$. group showed the largest number of private alleles $(\mathrm{n}=12)$, followed by Sajama $(\mathrm{n}=9)$, whereas the Nor Cinti exhibited the lowest number of private alleles $(n=2)$. The frequencies for these private alleles ranged between 0.007 and 0.105 . The most frequent private alleles were found in Sud Lípez and Nor Lípez for the markers LCA83 (allele frequency $(f)$ ' 197 ',$f=0.105$ ) and CMS13 (allele '246', $f=0.100$ ), respectively.

\section{Structure and genetic differentiation among regional groups}

Based on the 38 markers that satisfied the HW equilibrium criteria mentioned previously, the overall $F_{\mathrm{ST}}$ value among the 12 regional groups studied was $0.014(\mathrm{p}<0.001)$. The estimated pairwise $F_{\mathrm{ST}}$ values indicated low but significant levels of genetic differentiation ranging from 0.003 (between Invagi and Sajama) to 0.052 (between Nor Lípez and Sud Lípez) (Table 2). In addition to displaying the largest pairwise $F_{\mathrm{ST}}$ value $(0.052)$, Nor Lípez and Sud Lípez were also the groups with the largest degree of genetic differentiation $\left(F_{\mathrm{ST}}\right.$ values ranging from 0.024 to 0.046$)$ and the lowest level of gene flow rate $(\mathrm{Nm})(\mathrm{Nm}$ : range: $4.5-10.33$ ) with respect to the rest of the regional groups. For the other group pairs, the gene flow levels were quite large (Nm range: 13.68-89.16) (Table 2). Based on the $F_{\mathrm{ST}}$ behaviour for each marker in the entire population, seven of the 38 considered markers were identified as possible outlier loci $(\mathrm{p}<0.05)$. Using $F_{\mathrm{ST}}$ indices, we have identified 8 loci with extreme values of $F_{\mathrm{ST}}$ and/or $F_{\mathrm{IS}}$. Following Luikart et al. (2003), these markers were considered as 'outliers' or strong candidate for locus-specific effects (indicated in bold font in Table S3).

According to the Amova results, the estimated variability among and within regional groups was 1.52 and $98.48 \%$, respectively ( $\mathrm{p} \ll 0.001$ ). The samova analysis including additional spatial information of the regional groups analysed yielded similar results, with an estimated variability among groups of $1.48 \%$ $(\mathrm{p}<0.001)$. Although this result was associated with a number of estimated populations equal to 5 and 6 , the value of the corresponding genetic differentiation was very low $\left(F_{\mathrm{ST}}=0.015\right)$. The factorial analysis of correspondence also indicated a low global level of genetic differentiation, with the first three components together explaining a low level of variance (40\%; (Figure 2$)$. In the first component $(15.38 \%$ of the variance), eight of the studied regional groups grouped together, while Nor Lípez and Sud Lípez appeared slightly separated. The second component (13.16\% of the variance) showed the separation of the Sud Lípez group from Nor Lípez, while Franz Tamayo and Ingavi were only separated when the third component was taken into account $(11.41 \%)$. There was a high level of genetic overlapping between the individuals belonging to the remaining regional groups.

The population assignment analysis performed with the STRUCTURE software based on the 30 loci that 


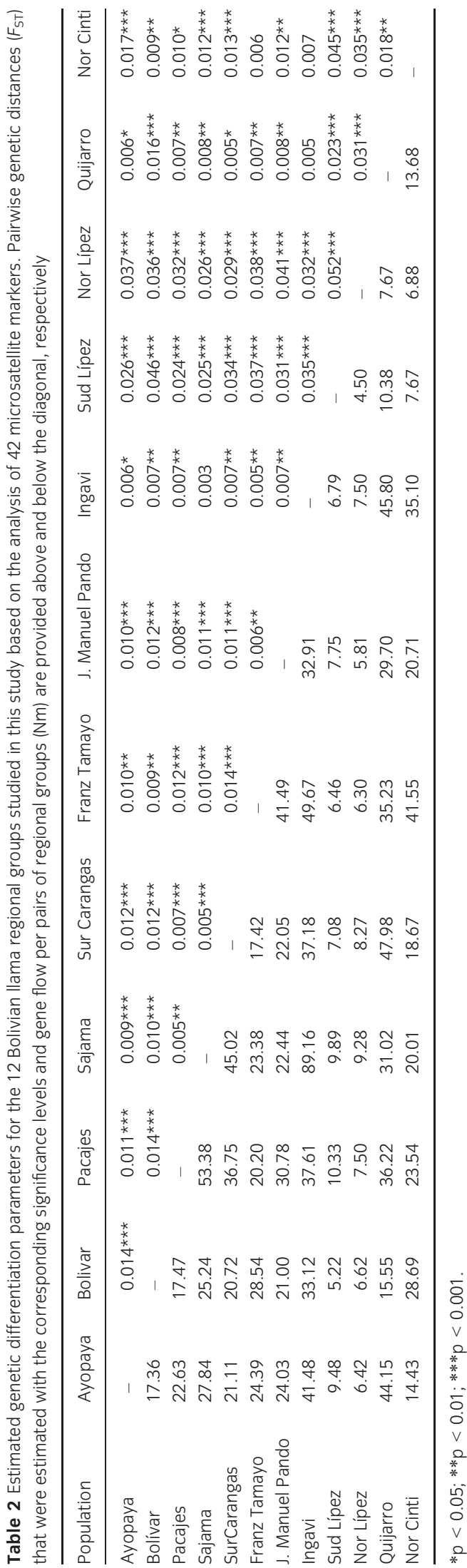

remained after discarding the outlier loci identified showed a $\mathrm{L}(K)$ profile that did not show a clear peak for any given value of $K$. Beginning at $K=5$, the increase in the $\mathrm{L}(K)$ profile was less pronounced and began to plateau, obtaining a maximum value at $K=13$ followed by the value associated with $K=14$ (Figure S1). Because of this plateau, we used the method of Evanno et al. (2005) to identify the more accurate value of $K$. The $\Delta \mathrm{K}$ profile, however, did not show a clear peak for any of the tested $K$ values. Aside from the artefact associated with $K=2$ that resulted from the markedly low likelihoods for $K=1$ (Vigouroux et al. 2008), there were two suggestive peaks, $K=5$ and $K=7$, but these peaks did not reach remarkably high $\Delta K$ values $(\Delta K=10.42$ and 2.78, respectively).

Based on this, the value of $K=5$ was chosen as the possible estimated number of populations, as it is known that in most structure analyses, once the real $K$ is reached, $\mathrm{L}(K)$ plateaus at larger $K$ s or continues to increase slightly (Evanno et al. 2005), and the variance between runs increases. The graphical representation of the clustering outcomes corresponding to $K=5$ (Figures S1 and S2) did not show any evidence of population structure, and distinct genetic differentiation was only indicated for Sud Lípez. Upon examining the proportion of membership assigned to each of the eight identified clusters corresponding to $K=5$, we observed that all of the clusters influenced, to a very low extent, most of the regional groups (average assignment proportion value $=0.190$ ) and only Sud Lípez could be considered to be associated with a single cluster with an assignment proportion of 0.60 . The results obtained with the BAPS software, also without outlier loci, suggested that the number of inferred clusters in each simulated scenario considering geographical localizations was only one. Also the best partition was identified for one cluster.

The additional analyses performed on the subset of individuals that were classified as the K'ara, T'hampulli or Intermediate type (data not shown) indicated that only $0.39 \%$ variability was observed between the different types considered. There was no indication of genetic differentiation, $F_{\mathrm{ST}}=0.003(\mathrm{p}<0.05)$, or population structure associated with the studied phenotypes.

\section{Discussion}

The present work provides the first survey on the genetic variability of Bolivian llamas based on the analysis of microsatellite markers. The samples analysed here were obtained from a wide range of localities 


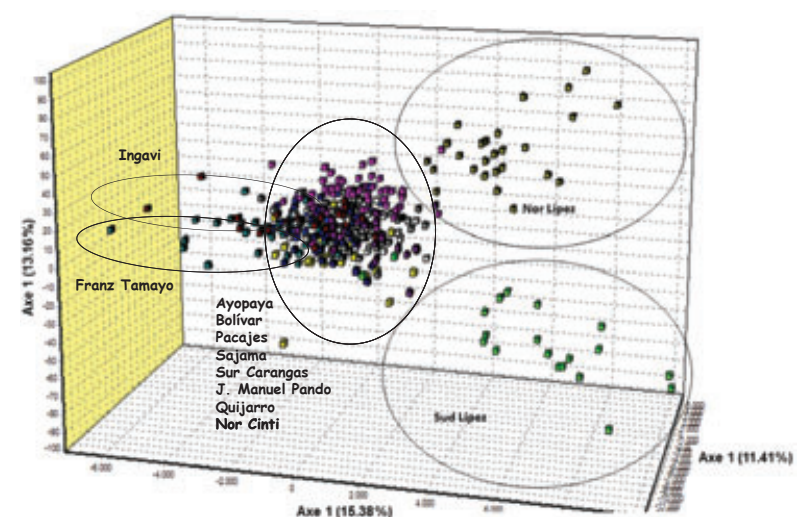

Figure 2 Spatial representation of the 394 llama individuals composing the 12 groups studied here as defined by the factorial correspondence analysis described in this work. The percentage of inertia that was determined by each component is indicated in parentheses.

encompassing most of the range of geographic distribution of this species in Bolivia. In terms of genetic variability, the 42 initially genotyped markers analysed in the 12 studied llama regional groups showed high levels of expected heterozygosity (He: 0.14-0.90) and a high average number of alleles (12.04). These results are comparable with those of previously reported population analyses in Argentinean llamas (He: 0.47-0.90, MNA: 8.33; Bustamante et al. 2002, 2006). The comparison of our results with estimates of genetic diversity in alpaca populations showed that higher values of expected heterozygosity have been reported for alpaca populations from Peru (He: 0.660.71, MNA: 7.2; Paredes et al. 2012) and Bolivia (He: 0.355-0.914, MNA: 11.7; Barreta et al. 2012). This comparison is of substantial interest from the conservation point of view, especially for Bolivian populations, because these two species are reared together in some areas of this country. In fact, the higher diversity estimates observed for alpaca populations could be explained by the high rates of hybridization reported in this species based on mitochondrial DNA analyses (Barreta et al. 2012, in press), although this should be confirmed by the assessment of hybridization based on the analysis of nuclear genetic markers.

Overall, the informativeness of the analysed markers was very high, with 27 of the 42 initially genotyped markers showing a PIC value higher than 0.6. A relatively large number of alleles per loci were observed in the entire analysed llama population. Some markers that had been reported by other authors as highly polymorphic in SACs, for example, LCA63, LCA66, VOLP68, GML5, YWLL8 and YWLL36 (Penedo et al. 1998b; Obreque et al. 1999; Bustamante et al. 2002), showed a larger number of alleles in our
Bolivian resource population. This observation is probably due to the large population analysed in this study and the use of some of these markers in a different species from that for which the marker was initially described. Based on the high level of polymorphism observed, we conclude that microsatellite loci can be efficiently used in Bolivian llamas for parentage control, study of population genetics and phylogeography or forensic investigations, as described before in other SAC populations (Sarno et al. 2000; Bustamante et al. 2006). The genetic variability information provided here can be of value when selecting microsatellite markers to perform some of the mentioned studied in Bolivian llamas.

The positive $F_{\text {IS }}$ value estimated for the entire population and significant heterozygosity deficits that were observed in some of the studied geographical groups, such as the Franz Tamayo, Ayopaya and Ingavi, are worth noting. In a population, several factors can contribute to identify a lower heterozygosis than expected, including inbreeding, the presence of null alleles and lack of neutrality relative to selection, with selection in favour of homozygotes (Maudet et al. 2002). It is important to note that in the central and northern Bolivian highlands, where the regional groups showing the highest $F_{\text {IS }}$ values in this work are located, in addition to a small number of effective llama breeders, the number of reproductive males used within the flocks and between neighbouring localities is quite limited. Obviously, these are management practices that can contribute to the significant heterozygosity deficits mentioned and that therefore should be taken into consideration in future management programmes.

Regarding the identification of a substantial number of private alleles $(p A=70)$ in the studied sample, it is interesting that these private alleles $(f=0.100-0.105)$ were also most frequently found in the Nor Lípez and Sud Lípez groups. In these two geographical groups, we also found two fixed alleles for CMS25 in Nor Lípez and for PCTD17 in Sud Lípez. Other studies have also noted a remarkable number of private alleles in Argentinean llama populations (Bustamante et al. 2002, 2006), in some cases showing frequencies higher than 0.20 (Bustamante et al. 2006). The presence of private and fixed alleles at a high frequency may indicate that the corresponding populations are distinctive gene pools obtained by genetic drift or selection (artificial or natural). However, at this moment, due to the lack of a proper linkage map or genome assembly for this species, it is not possible to draw a stronger conclusion about this point. 
The overall genetic differentiation identified in the wide set of Bolivian llamas studied here was low $\left(F_{\mathrm{ST}}=0.014\right)$. This level of genetic differentiation is considerably lower than the levels reported for other populations of domestic SACs, such as Argentinean llamas and Peruvian and Bolivian alpacas $\left(F_{\mathrm{ST}}\right.$ range: 0.03-0.07; Bustamante et al. 2006; Paredes et al. 2012; Barreta et al. 2012).

Despite the high altitudinal differences between the populations studied here (range: 2500-4500 metres above sea level), the estimated genetic differentiation levels between all of the pairs of Bolivian llama regional groups in this study were quite low (pairwise $F_{\mathrm{ST}}$ range: $0.003-0.052$ ), revealing that the genetic structuring of the studied population is weak (Wright 1978) and that there is a substantial gene flow connecting these regional groups. However, we should take into account the fact that the southern Nor Lípez and Sud Lípez localities showed the highest pairwise $F_{\text {ST }}$ value $\left(F_{\text {ST }}=0.052\right)$ and also higher values when compared with the rest of the geographical groups ( $F_{\mathrm{ST}}$ range: $\left.0.024-0.046\right)$. In contrast, the central and northern Altiplano populations showed a high level of genetic similarity and very low values for pairwise genetic distance estimates ( $F_{\mathrm{ST}}$ range: 0.003-0.018). These results are associated with high gene flow levels and are probably due to the exchange of reproductive males in traditional regional fairs (Iñiguez \& Alem 1996). Interestingly, these observations were supported by the factorial analysis of correspondence (Figure 2), which graphically illustrated the close genetic relationship between most of the animals, whereas a distinct level of genetic differentiation was detected only for Sud Lípez and to a lower extent for Nor Lípez.

The results of the cluster assignment analyses performed with the sTRUCTURE showed a weak genetic structure in the studied population, which was consistent with a strong gene flow between all of the localities studied. The lack of correspondence between the most likely value of $K(K=5)$ and the distribution of animals in the five clusters indicates that this numerical result has no biological meaning. This hypothesis was supported by the BAPS spatial analysis. These findings contrast with the clear genetic structure that was identified in Bolivian alpacas that were sampled from similar localities to those studied here (Barreta et al. 2012). The observed difference between the genetic structure of Bolivian llamas and alpacas is probably due to differences in the management practices used for these two species of domestic SACs. Bolivian llamas are primarily used for meat production, mainly for subsistence, and are used only secondarily for fibre production (Iñiguez et al. 1998). Hence, llamas are reared by local breeders without following specific breeding programmes, and their husbandry involves an intensive exchange of reproductive males between close geographical localities.

Despite the lack of genetic structure observed in our population, the reported analyses suggest a distinct pattern of isolation based on geographic position for Sud Lípez and to a lower extent for Nor Lípez. This hypothesis of isolation agrees with the fact that the exchange of animals is more frequent between geographically close localities than among remote localities, although the availability of appropriate communication infrastructures is also an important factor. Actually, these two localities, which are only $183 \mathrm{~km}$ apart, are remote community areas with limited transportation or communication infrastructure and are surrounded by extreme geographies. This could explain that they showed the largest genetic distances with the other sampling areas and also between them $\left(F_{\mathrm{ST}}=0.052\right)$. In contrast, for other regional groups showing large geographical distances but being more easily connected by transportation, the exchange of reproductive males is much more intensive, for example, Franz Tamayo and Pacajes $\left(320 \mathrm{~km} ; F_{\mathrm{ST}}=0.012\right)$. Also, it is worth mentioning that the Sud Lípez and Nor Lípez localities, where the $\mathrm{T}^{\prime}$ hampulli and Intermediate types of llama are predominant (89\% of the population), are associated with the production of a fibre of higher quality than that which is produced from the other localities studied here (Stemmer et al. 2005). Hence, llamas from these two regions are revealed by our analyses to be an important genetic resource that could have a key role in improving fibre production traits of Bolivian llamas (Iñiguez et al. 1998). The other region that has a high proportion of $\mathrm{T}^{\prime}$ hampulli llamas is Ayopaya (89\% T'hampulli within this regional group) (Stemmer et al. 2005). However, this group showed more connectivity with the localities of the central Bolivian plateau than with the southern localities. The analyses we performed to examine the different types of llamas ( $\mathrm{T}^{\prime}$ hampulli, K'ara and Intermediate) did not show any genetic differentiation between the groups considered. These results showing a lack of genetic structure between groups that show phenotypic differentiation due to human selection could be explained by the fact that the markers analysed in our study are neutral markers and breed differentiation is based mainly on fibre type and diameter. Hence, the study of candidate genes related to the phenotypic differences observed could identify allele variants 
underlying single-nucleotide polymorphisms (SNPs) related to the studied phenotypes or performed studies of population genomics. On this regard, it is expected that the high-throughput genomic tools that are available today for many livestock species, could help, in a short future, to increase our knowledge on the genome of SAC species.

This study, which to our knowledge is the first detailed analysis of the genetic diversity of Bolivian llamas, has shown a high level of genetic variability and a weak genetic structure in the studied population. As an overall, the population parameters reported here may serve as a reference for establishing conservation policies involving, for example, the maintenance of the possible genetic pools that were identified in the southern regions of the country.

\section{Acknowledgements}

We gratefully acknowledge the financial support received from the AECID by projects A/010497/07 and A/017114/08. Julia Barreta's scholarship has been provided by a MAE-AECID fellowship (Spanish Agency for International Development Cooperation; Spanish Ministry of Foreign Affairs and Cooperation). We also acknowledge financial support from the Swedish Cooperation Agency (SIDA) and Bancamel INIAF to UMSA and from the project for Genetic Diversity of Llamas in Bolivia as well as logistical support from the Institute of Aymara Language and Culture (ILCA). Finally, we acknowledge the support of the people who generously helped by providing information and samples for this study in Bolivia: Denise Arnold, Luis Iñiguez, Carlos Coello, Franz Bustos, Edwin Torrico, Luis Gutiérez, Fernando Arevillca, David Pérez, Ramiro Colque, Einstein Tejada, Silvia Quispe and Candelaria Socavón.

\section{References}

Barreta J., Iñiguez V., Saavedra V., Romero F., Callisaya A. M., Echalar J., Gutierréz-Gil B., Arranz J.J. (2012) Genetic diversity and population structure of Bolivian alpacas. Small Rumin. Res., 105, 97-104.

Barreta J., Gutiérrez-Gil B., Iñiguez V., Saavedra V., Chiri R., Latorre E., Arranz J.J. (in press) Analysis of mitochondrial DNA in Bolivian llama, alpaca and vicuna populations: a contribution to the phylogeny of the South American camelids. Anim. Genet., doi: 10.1111/ j.1365-2052.2012.02376.x.

Bustamante A., Zambelli A., de Lamo D., von Thungen J., Vidal Rioja L. (2002) Genetic variability of guanaco and llama populations in Argentina. Small Rumin. Res., 44, 97-101.

Bustamante A., Maté M.L. , Lamas H.E., Giovambattista G., Zambelli A., Vidal L.R. (2006) Análisis de diversidad genética en tres poblaciones de llamas (Lama glama) del noroeste argentino. Rev. Chil. Hist. Nat., 79, 175-187.

Doyle J.J., Doyle J.L. (1987) A rapid DNA isolation procedure for small quantities of fresh leaf tissue. Phytochem. Bull., 19, 11-15.

Evanno G., Regnaut S., Goudent J. (2005) Detecting the number of clusters of individuals using the software STRUCTURE: a simulation study. Mol. Ecol., 14, 2611-2620.

Hammond K. (1994) Conservation of domestic animal diversity: global overview. Proceedings of the World Congress on Genetics Applied to Live-stock Production, 21, 423-439.

INE (Instituto Nacional de Estadística) (2008) Datos estadísticos. INE, Bolivia, April 2008, http://www.ine. gov.bo

Iñiguez L., Alem R. (1996) La función de los camélidos como medio de transporte e intercambio en la región andina de Bolivia. World Anim. Rev., 1, 12-21.

Iñiguez L.C., Alem R., Wauer A., Mueller J. (1998) Fleece types, fiber characteristics and production system of an outstanding llama population from southern Bolivia. Small Rumin. Res., 30, 57-65.

Lauvergne J.J., Martínez Z., Ayala C., Rodríguez T. (2001) Identification of a primary population of South American domestic Camelids in the provinces of Antonio Quijarro and Enrique Baldivieso (Departament of Potosí) using the phenotype variation of coat colour. In: M. Gerken, C. Renieri (Eds). Progress in South American Camelids Research, vol. 105. EAAP Publ., Xxxxxxx, pp. 64-74.

Luikart G., Gielly L., Excoffier L., Vigne J.D., Bouvet J., Taberlet P. (2001) Multiple maternal origins and weak phylogeographic structure in domestic goats. Proc. Natl. Acad. Sci., 98, 5927-5932.

Luikart G.H., England P., Tallmon D.A., Jordan S., Taberlet P. (2003) The power and promise of population genomics: from genotyping to genome-typing. Nat. Rev. Genet., 4, 981-994.

Mackermann A., Stemmer A., Siegmund-Schultze M., Piepho H.-P., Valle Zárate A. (2009) Stated preferences of llama keeping functions in Bolivia. Livest. Sci., 124, 119-125.

Maté M.L., Bustamante A.V., Giovambattista G., Delamo D., Lamas H., Von Thungen J., Zambelli A., Vidal-Rioja L. (2005) Genetic diversity and differentiation of guanaco populations from Argentina inferred from microsatellite data. Anim. Genet., 36, 316-321.

Maudet C., Luikart G., Taberlet P. (2002) Genetic diversity and assignment tests among seven French cattle breeds 
based on microsatellite DNA analysis. J. Anim. Sci., 80, 942-950.

Mengoni Goñalons G.L. (2008) Camelids in ancient Andean societies: A review of the zooarchaeological evidence. Quart. Int., 185, 59-68.

Obreque V., Mancilla R., Garcia-Huidobro J., Cothran E. G., Hinrichsen P. (1999) Thirteen new dinucleotide microsatellites in Alpaca. Anim. Genet., 30, 397-398.

Paredes M., Machaca J., Azor P.J., Alonso-Moraga A., Membrillo A., Muñoz-Serrano A. (2012) Genetic differentiation of six Peruvian alpaca populations. In: M. Paredes (ed.), Fibre Production in South American Camelids and Other Fibre Animals. Wageningen Academic Publishers, The Netherlands, pp. 161-166. Sarno R., David V., Franklin W., O'Brien S., Johnson W. (2000) Development of microsatellite markers in the guanaco, Lama guanicoe: utility for South American camelids. Mol. Ecol., 9, 1922-1924.

Sarno R.J., Villalba L., Bonacic C., Gonzalez B., Zapata B., Mac Donald D.W., O’Brien S.J., Jonson W.E. (2004) Phylogeography and subspecies assessment of vicuñas in Chile and Bolivia utilizing mtDNA and microsatellite markers: implications for vicuña conservation and management. Conserv. Genet., 5, 89-102.

Stemmer A., ValleZárate A., Nürnberg M., Delgado J., Wurzinger M., Sölkner J. (2005) La llama de Ayopaya: descripción de un recurso genético autóctono. Arch. Zoot., 54, 253-359.

Vigouroux Y., Glaubitz J.C., Matsuoka Y., Goodman M.M., Sánchez G.J., Doebley J. (2008) Population structure and genetic diversity of new world maize races assessed by DNA microsatellites. Am. J. Bot., 95, 1240-1253.

Webster S. (1973) Native pastoralism in the South Andes. Ethnology, 12, 115-133.

Weir B.S., Cockerham C.C. (1984) Estimating F-statistics with special regard to system of mating. Evolution, 38, 1358-1370.

Wheeler J.C. (1995) Evolution and present situation of the South American Camelidae. Biol. J. Linn. Soc., 54, 271-295.

Woodward S.R., King M.J., Chiu N.M., Kuchar M.J., Griggs C.W. (1994) Amplification ancient nuclear DNA from teeth and soft tissues. PCR Methods Appl., 3, 244-247.
Wright S. (1978) Evolution and the Genetics of Populations vol. 4, Variability Within and Among Natural Populations. University of Chicago Press, Chicago, IL.

Wurzinger M., Delgado J., Nurnberg M., Valle Zárate A., Stemmer A., Ugarte G., Solkner J. (2005) Growth curves and genetic parameters for growth traits in Bolivian llamas. Livest. Prod. Sci., 95, 73-81.

Wurzinger M., Willam A., Delgado J., Nürnberg M., Zárate A.V., Stemmer A., Ugarte G., Sölkner J. (2008) Design of a village breeding programme for a llama population in the High Andes of Bolivia. J. Anim. Breed. Genet., 125, 311-319.

\section{Supporting Information}

Additional Supporting Information may be found in the online version of this article:

Figure S1 Graphical representation of the proportion of membership of each of the analysed llama populations for $\mathrm{K}=5$ as obtained with the strUCtURE software.

Table S1 (a) Description of the type of samples used in this work for the 24 different localities sampled. These localities were grouped in the 12 llama groups indicated according the geographical proximity criteria. (b) Description of the geographical distance between pairs of groups used in this work for the 24 different localities sampled. These localities were grouped in the 12 llama groups indicated according the geographical proximity criteria.

Table S2 Four multiloading panels were used for genotyping of the 42 microsatellites analysed in this study.

Table S3 Genetic diversity parameters estimated for the 42 microsatellite markers analyzed across the 12 llama groups considered in this study.

Please note: Wiley-Blackwell are not responsible for the content or functionality of any supporting materials supplied by the authors. Any queries (other than missing material) should be directed to the corresponding author for the article. 


\section{Supporting Information}

Supporting Information Table S1 Description of the type of samples used in this work for the 24 different localities sampled. These localities were grouped in the 12 llama population indicated according the geographical proximity criteria.

\begin{tabular}{|c|c|c|c|c|}
\hline Species & Sample & Locality & Population & $N$ \\
\hline \multirow[t]{12}{*}{ Llama } & Hair & Ayopaya, Quillacollo, Arani & Ayopaya & 36 \\
\hline & Hair & Bolívar & Bolívar & 29 \\
\hline & Hair, Blood & Pacajes, San Pedro de Totora, Nor Carangas & Pacajes & 39 \\
\hline & Hair, Blood & Sajama, Turco, Carangas, La Rivera & Sajama & 49 \\
\hline & Hair, Blood & Sur Carangas, Orinoca, Avaroa & Sur Carangas & 69 \\
\hline & Hair & Franz Tamayo & Franz Tamayo & 39 \\
\hline & Hair & J. Manuel Pando & J. Manuel Pando & 30 \\
\hline & Hair & Ingavi ,Yawaroko & Ingavi & 25 \\
\hline & Hair & Sud Lípez & Sud Lípez & 19 \\
\hline & Blood & Nor Lípez & Nor Lípez & 25 \\
\hline & Hair & Quijarro, Tomás Frías & Quijarro & 20 \\
\hline & Hair & Nor Cinti , Tarija & Nor Cinti & 14 \\
\hline Total samples & & & & 394 \\
\hline
\end{tabular}


Supporting Information Table S2 Four multiloading panels were used for genotyping of the 42 microsatellites analysed in this study. Each multiloading panel included one or two groups of markers amplified in the same reaction by multiplex-PCR. The names of the markers analysed, the fluorochrome labeling and PCR-hybridization temperature are given in the table together with the allele range observed for each marker in the Bolivian llama samples analysed.

\begin{tabular}{|c|c|c|c|c|}
\hline Multiloading & Hybridization $\mathbf{T}^{\mathbf{a}}$ & Fluorochrome & Marker & Alelle range \\
\hline \multirow{10}{*}{1} & \multirow{10}{*}{$58^{\circ} \mathrm{C}$} & \multirow[t]{4}{*}{ FAM } & LCA19 & $78-116$ \\
\hline & & & LCA37 & $122-170$ \\
\hline & & & $Y W L L 40$ & $175-185$ \\
\hline & & & $Y L L 29$ & $209-225$ \\
\hline & & \multirow[t]{2}{*}{ HEX } & YWLL08 & $125-185$ \\
\hline & & & LCA08 & $225-257$ \\
\hline & & \multirow[t]{4}{*}{ NED } & YWLL36 & $135-179$ \\
\hline & & & LCA05 & $182-210$ \\
\hline & & & LCA66 & $215-256$ \\
\hline & & & YWLL44 & $80-126$ \\
\hline \multirow{12}{*}{2} & \multirow[t]{5}{*}{$58^{\circ} \mathrm{C}$} & \multirow[t]{3}{*}{ FAM } & CMS104 & $90-136$ \\
\hline & & & LCA70 & $202-234$ \\
\hline & & & CMS13 & $240-262$ \\
\hline & & \multirow[t]{3}{*}{ VIC } & VOLP68 & $128-170$ \\
\hline & & & LCA83 & $189-217$ \\
\hline & \multirow{7}{*}{$55^{\circ} \mathrm{C}$} & & CMSO3 & $240-262$ \\
\hline & & \multirow[t]{3}{*}{ NED } & LCA56 & $135-149$ \\
\hline & & & LCA68 & $186-216$ \\
\hline & & & LCA77 & $230-260$ \\
\hline & & \multirow[t]{3}{*}{ PET } & LCA85 & $191-233$ \\
\hline & & & VOLP77 & $135-177$ \\
\hline & & & CMS25 & $92-118$ \\
\hline \multirow{11}{*}{3} & \multirow{11}{*}{$59^{\circ} \mathrm{C}$} & \multirow[t]{3}{*}{ FAM } & $Y W L L 43$ & $125-155$ \\
\hline & & & LCA18 & $210-238$ \\
\hline & & & LCA99 & $260-296$ \\
\hline & & \multirow[t]{4}{*}{ NED } & $Y W L L 46$ & $91-107$ \\
\hline & & & LCA54 & $135-149$ \\
\hline & & & LGLU50 & 181-195 \\
\hline & & & LCA63 & $206-252$ \\
\hline & & VIC & LCA71 & $133-145$ \\
\hline & & \multirow[t]{2}{*}{ PET } & VOLP05 & $135-155$ \\
\hline & & & LGLU49 & $218-250$ \\
\hline & & FAM & LCA23 & $163-203$ \\
\hline \multirow{9}{*}{4} & \multirow{6}{*}{$62{ }^{\circ} \mathrm{C}$} & \multirow[t]{2}{*}{ NED } & PCTD17 & $146-158$ \\
\hline & & & P194 & $172-204$ \\
\hline & & \multirow[t]{2}{*}{ FAM } & P193 & $148-172$ \\
\hline & & & P132 & $80-102$ \\
\hline & & & P57 & $208-232$ \\
\hline & & HEX & P86 & $159-233$ \\
\hline & & HEX & P149 & $245-307$ \\
\hline & $58^{\circ} \mathrm{C}$ & FAM & P147 & 276-306 \\
\hline & & NED & P135 & $206-232$ \\
\hline
\end{tabular}


Supporting Information Table S3 Genetic diversity parameters estimated for the $\mathbf{4 2}$ microsatellite markers analyzed across the 12 llama populations considered in this study.

\begin{tabular}{|c|c|c|c|c|c|c|c|}
\hline Marker & $\mathrm{NA}^{1}$ & $\mathrm{Ho}^{2}$ & $\mathrm{He}^{3}$ & $\mathrm{HWE}^{4}$ & $\mathrm{Fis}^{5}$ & $\mathrm{~F}(\text { null })^{6}$ & $\mathrm{PIC}^{7}$ \\
\hline CMSO3 & 4 & 0.348 & 0.453 & 0.0000 & 0.232 & 0.083 & 0.365 \\
\hline CMS104 & 4 & 0.167 & 0.285 & 0.0000 & 0.416 & 0.123 & 0.259 \\
\hline CMS13 & 12 & 0.662 & 0.710 & 0.0009 & 0.067 & 0.036 & 0.679 \\
\hline CMS25 & 7 & 0.114 & 0.141 & 0.0016 & 0.189 & 0.053 & 0.139 \\
\hline GML5 & 16 & 0.837 & 0.868 & 0.4751 & 0.036 & 0.030 & 0.854 \\
\hline LCA05 & 11 & 0.656 & 0.693 & 0.0408 & 0.054 & 0.025 & 0.649 \\
\hline LCA08 & 15 & 0.804 & 0.846 & 0.4180 & 0.049 & 0.024 & 0.828 \\
\hline LCA18 & 13 & 0.761 & 0.789 & 0.0158 & 0.035 & 0.015 & 0.762 \\
\hline LCA19 & 16 & 0.464 & 0.574 & 0.0000 & 0.191 & 0.069 & 0.553 \\
\hline LCA23 & 28 & 0.706 & 0.796 & 0.0000 & 0.112 & 0.054 & 0.781 \\
\hline LCA37 & 23 & 0.751 & 0.859 & 0.0000 & 0.125 & 0.061 & 0.846 \\
\hline LCA54 & 8 & 0.513 & 0.602 & 0.0000 & 0.147 & 0.088 & 0.530 \\
\hline LCA56 & 12 & 0.744 & 0.769 & 0.6729 & 0.032 & 0.016 & 0.734 \\
\hline LCA63 & 22 & 0.657 & 0.853 & 0.0000 & 0.230 & 0.097 & 0.837 \\
\hline LCA66 & 31 & 0.777 & 0.856 & 0.0000 & 0.093 & 0.047 & 0.847 \\
\hline LCA68 & 10 & 0.612 & 0.767 & 0.0000 & 0.202 & 0.091 & 0.730 \\
\hline LCA70 & 8 & 0.659 & 0.694 & 0.0049 & 0.050 & 0.017 & 0.648 \\
\hline LCA71 & 6 & 0.558 & 0.604 & 0.0029 & 0.076 & 0.104 & 0.569 \\
\hline LCA77 & 12 & 0.697 & 0.729 & 0.0000 & 0.044 & 0.025 & 0.683 \\
\hline LCA83 & 11 & 0.745 & 0.773 & 0.0110 & 0.036 & 0.107 & 0.738 \\
\hline LCA85 & 10 & 0.743 & 0.816 & 0.0000 & 0.089 & 0.039 & 0.792 \\
\hline LCA99 & 16 & 0.726 & 0.785 & 0.0322 & 0.075 & 0.043 & 0.767 \\
\hline$L G L U 49$ & 16 & 0.856 & 0.869 & 0.0000 & 0.015 & 0.017 & 0.854 \\
\hline LGLU50 & 7 & 0.497 & 0.597 & 0.0000 & 0.167 & 0.073 & 0.555 \\
\hline VOLP5 & 11 & 0.817 & 0.858 & 0.0029 & 0.048 & 0.025 & 0.839 \\
\hline VOLP68 & 12 & 0.631 & 0.761 & 0.0000 & 0.171 & 0.098 & 0.735 \\
\hline YWLL08 & 28 & 0.832 & 0.901 & 0.0000 & 0.077 & 0.039 & 0.893 \\
\hline YWLL29 & 8 & 0.768 & 0.798 & 0.5634 & 0.037 & 0.061 & 0.769 \\
\hline YWLL36 & 13 & 0.789 & 0.809 & 0.2608 & 0.025 & 0.020 & 0.783 \\
\hline YWLL40 & 6 & 0.556 & 0.574 & 0.4095 & 0.032 & 0.035 & 0.537 \\
\hline YWLL43 & 16 & 0.628 & 0.884 & 0.0000 & 0.289 & 0.141 & 0.873 \\
\hline YWLL44 & 20 & 0.806 & 0.864 & 0.2059 & 0.068 & 0.036 & 0.850 \\
\hline YWLL46 & 8 & 0.616 & 0.681 & 0.0032 & 0.096 & 0.072 & 0.644 \\
\hline P132 & 6 & 0.520 & 0.516 & 0.0003 & -0.009 & 0.017 & 0.448 \\
\hline P135 & 12 & 0.569 & 0.838 & 0.0000 & 0.320 & 0.145 & 0.817 \\
\hline P147 & 8 & 0.611 & 0.627 & 0.0103 & 0.026 & 0.131 & 0.587 \\
\hline P149 & 7 & 0.200 & 0.204 & 0.0000 & 0.016 & 0.022 & 0.192 \\
\hline P193 & 5 & 0.568 & 0.546 & 0.0371 & -0.041 & 0.020 & 0.441 \\
\hline P194 & 5 & 0.130 & 0.603 & 0.0000 & 0.785 & 0.497 & 0.549 \\
\hline P57 & 11 & 0.562 & 0.841 & 0.0000 & 0.332 & 0.152 & 0.821 \\
\hline P86 & 9 & 0.259 & 0.259 & 0.0130 & 0.000 & 0.049 & 0.247 \\
\hline PCTD17 & 3 & 0.208 & 0.222 & 0.1563 & 0.063 & 0.024 & 0.199 \\
\hline Average & 12.04 & 0.59828 & 0.679 & & & & \\
\hline
\end{tabular}

${ }^{1}$ NA: Number of alleles per locus in the global population.

${ }^{2}$ Ho: Average observed heterozygosity.

${ }^{3} \mathrm{He}$ : Average expected heterozygosity.

${ }^{4} \mathrm{HWE}$ : Hardy-Weinberg Equilibrium test significance. The markers showing significant deviation from the HWE test, after considering the multiple number of tests performed, are indicated in bold font $(P<0.0001)$. ${ }^{5} F_{\text {IS }}$ : Coefficient of inbreeding.

${ }^{6} \mathrm{~F}$ (null): Frequency of null alleles.

${ }^{7}$ PIC: Polymorphic information content. 
Supporting Information Figure S1 Graphical representation of the proportion of membership of each of the analysed llama populations for $\mathrm{K}=8$ as obtained with the STRUCTURE software.

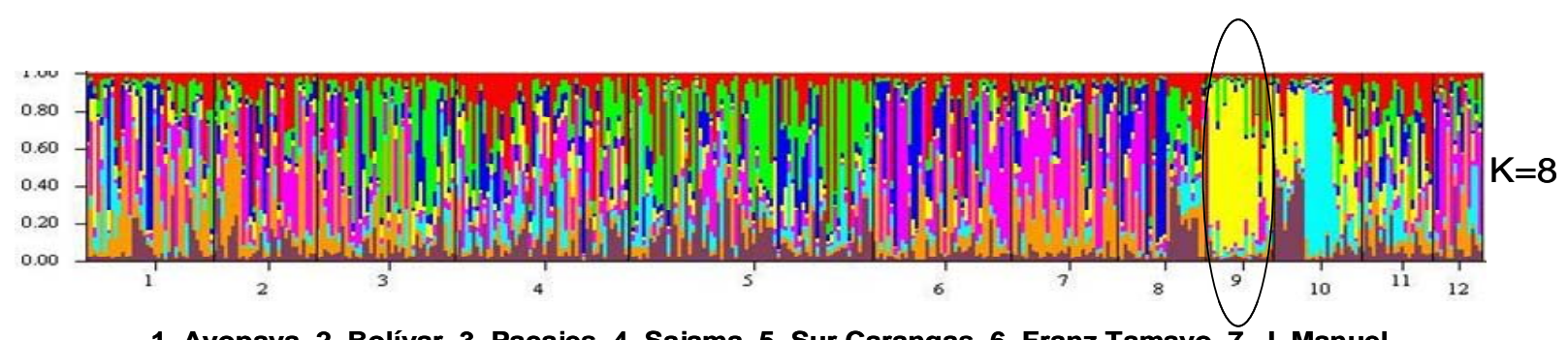

1. Ayopaya, 2. Bolívar, 3. Pacajes, 4. Sajama, 5. Sur Carangas, 6. Franz Tamayo, 7. J. Manuel Pando, 8. Ingavi, 9. Sud Lípez, 10.Nor Lípez, 11. Quijarro, 12. Nor Cinti 


\section{Additional references:}

\section{Description of microsatellite sequences in SAC used inthis paper:}

Bustamante, A., Mate, M.L., Zambelli, A., Vidal, L.R. (2003) Isolation and characterization of 10 polymorphic dinucleotide microsatellite markers for llama and guanaco. Mol. Ecol. Not., 3, 68-9.

Lang, K.D., Wang, Y., Plante, Y. (1996) Fifteen polymorphic dinucleotide microsatellites in llamas and alpacas. Anim. Genet., 27, 293.

Munyard, K.A., Ledger, J.M., Lee, C.Y., Babra, C. D., Groth, M. (2009) Characterization and multiplex genotyping of alpaca tetranucleotide microsatellite markers. Small Rumin. Res. doi:10.1016/j.smallrumres.2009.07.012.

Obreque, V., Mancilla, R., Garcia-Huidobro, J., Cothran, E.G., Hinrichsen, P. (1999) Thirteen new dinucleotide microsatellites in Alpaca. Anim. Genet., 30, 397-398.

Penedo, M.C., Caetano, A. R., Cordova, K. I. (1998a) Microsatellite markers for South American camelids. Anim. Genet., 29, 411-2.

Penedo, M.T.C., Caetano, A.R., Cordova, K. 1998(b) Eight microsatellite markers for South American camelids. Anim. Genet. 30, 161-168.

\section{Population Genetics Software used in this paper}

Corander, J., Sirén, J., Arjas, E. (2008) Bayesian Spatial Modelling of Genetic Population Structure. Computational Statistics 23, 111-129.

Dupanloup, I., Schneider, S., Excoffier, L. (2002) A simulated annealing approach to define the genetic structure of populations. Mol. Ecol., 11, 2571-2581. 
Earl, D.A., VonHoldt, B.M. (2011) STRUCTURE HARVESTER: a website and program for visualizing STRUCTURE output and implementing the Evanno method. Conserv. Genetic. Res., doi: 10.1007/s12686-011-9548-7.

Excoffier, L., Laval, G., Schneider, S. (2005) Arlequin ver.3.0: an integrated software package for population genetics data analysis. Evol. Bioinform. On., 1, 47-50.

Gutiérrez, J.P., Royo, L.J., Alvarez, I., Goyache, F. (2005) MolKin v2.0: a computer program for genetic analysis of populations using molecular coancestry information. J. Hered., 96, 718-721.

Pritchard, J.K., Stephens, M., Donnelly, P. J. (2000) Inference of population structure using multilocus genotype data. Genetics, 155, 945-959.

Raymond, M., Rousset, F. (1995) Genepop (version 1.2): population genetics software for exact tests and ecumenicism. J. Hered., 86, 248-249. 


\section{GENETIC DIVERSITY AND POPULATION STRUCTURE OF BOLIVIAN}

ALPACAS.

Barreta J, Iñiguez V, Saavedra V, Romero, F, Callisaya AM, Echalar, J, Gutiérrez-Gil B, Arranz JJ.

Small Ruminant Research 2012, 105, (1-3): 97-104. 

Provided for non-commercial research and education use. Not for reproduction, distribution or commercial use.

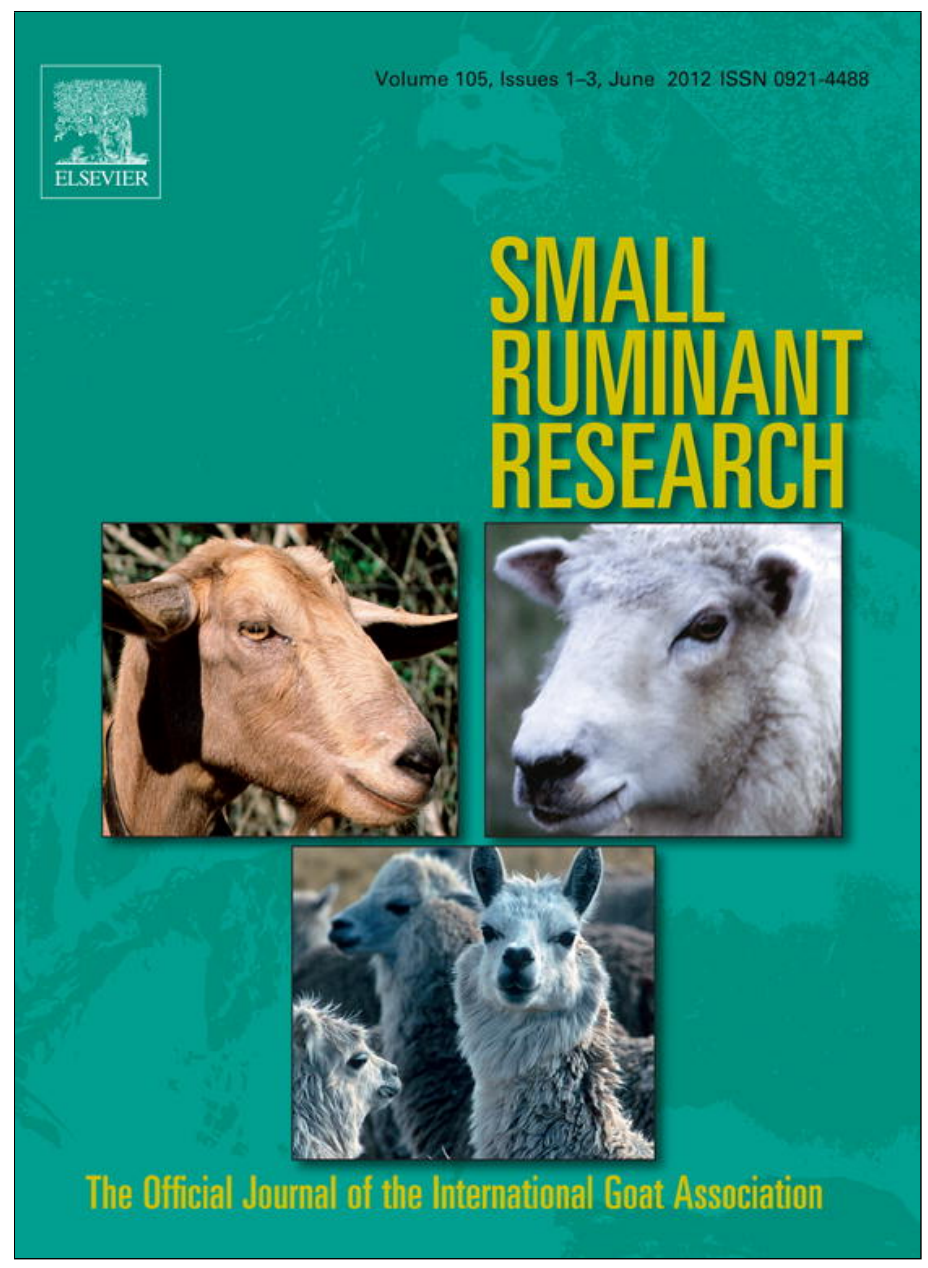

This article appeared in a journal published by Elsevier. The attached copy is furnished to the author for internal non-commercial research and education use, including for instruction at the authors institution and sharing with colleagues.

Other uses, including reproduction and distribution, or selling or licensing copies, or posting to personal, institutional or third party websites are prohibited.

In most cases authors are permitted to post their version of the article (e.g. in Word or Tex form) to their personal website or institutional repository. Authors requiring further information regarding Elsevier's archiving and manuscript policies are encouraged to visit:

http://www.elsevier.com/copyright 


\title{
Genetic diversity and population structure of Bolivian alpacas
}

\author{
Julia Barreta ${ }^{a, b}, V$ Volga Iñiguez ${ }^{a, * *}$, Vladimir Saavedra ${ }^{c}$, Fernando Romero $^{a}$, \\ Ana María Callisaya ${ }^{\mathrm{a}}$, Joely Echalar ${ }^{\mathrm{a}}$, Beatriz Gutiérrez-Gil ${ }^{\mathrm{b}}$, Juan-José Arranz ${ }^{\mathrm{b}, *}$ \\ a Instituto de Biologia Molecular y Biotecnologia, UMSA, La Paz, Bolivia \\ b Dpto. Produccion Animal, Universidad de Leon, Spain \\ c Centro Experimental Agropecuario Condoriri, Facultad de Ciencias Agrarias y Veterinarias, Universidad Técnica de Oruro, Banco de Germoplasma, \\ INIAF, Oruro, Bolivia
}

\section{A R T I C L E I N F O}

\section{Article history:}

Received 29 December 2011

Received in revised form 27 February 2012

Accepted 1 March 2012

Available online 28 March 2012

\section{Keywords:}

Alpaca

Genetic diversity

Microsatellites

Bolivia

Genetic structure

\begin{abstract}
A B S T R A C T
We have examined the genetic diversity and population structure of 149 Bolivian alpacas from eight different locations in Bolivia. The analysis of 22 microsatellite loci revealed high levels of genetic diversity, similar to the results reported in other alpaca populations. This high genetic variability was sustained by the identification of a total of 258 alleles; we identified between 4 and 18 alleles per locus with high levels of observed heterozygosity that ranged from 0.611 to 0.696 . The inbreeding coefficients (Fis) were positive and significantly different from zero for all of the populations except for Turco. The genetic differentiation between populations (Fst) was low to moderate with pair-wise Fst estimates ranging from 0.008 for the Curahuara-Cosapa pair, to 0.077 for the Poopó-Ayopaya and Poopó-Ulla Ulla pairs. The analysis of molecular variance (AMOVA) indicated that the total variability observed between different populations was $3.86 \%$, whereas $96.14 \%$ of the variation was found within the populations. The population structure analysis revealed that the eight studied populations could be assigned to five differentiated clusters. In agreement with the factorial analysis of correspondence, and supported through a bootstrapping analysis to adjust for differences in population sample size, this analysis suggested a genetic isolation of the Poopó population and the influence of the Turco population on the populations linked to the Cochabamba and the Pacajes-Sajama alpaquero systems. The Ulla Ulla population showed a clear subdivision into two clusters; in addition, these two clusters had an influence on the Challapata population and less impact on the rest of the populations. The Cosapa, Lagunas and Curahuara populations showed a clear common genetic background, whereas the Ayopaya population was influenced by the five defined clusters. Despite some sampling limitations and the need of confirming the results reported here through larger datasets, overall, this study provides the first survey of the genetic diversity in Bolivian alpaca populations, which may be of great value for the development of appropriate breeding strategies for these populations.
\end{abstract}

(c) 2012 Elsevier B.V. All rights reserved.

\footnotetext{
* Corresponding author at: Dpto. Producción Animal, Facultad de Veterinaria, Universidad de León, 24071 León, Spain. Tel.: +34 987 291470; fax: +34987291311.

** Corresponding author at: Instituto de Biología Molecular y Biotecnología, Facultad de Ciencias Puras y Naturales, Universidad Mayor San Andrés, Campus Universitario Cota Cota c/27, s/n, La Paz, Bolivia. Tel.: +59122612815.

E-mail addresses: volgavir@yahoo.com (V. Iñiguez), jjarrs@unileon.es (J.-J. Arranz).
}

\section{Introduction}

At present, the alpaca (Lama pacos) is the most abundant species among the South America Camelids. The geographic distribution of this species includes Peru, Bolivia and Chile, and after exportation, New Zealand, Australia, the United States and Canada (Morante et al., 2009). In the Andean region of Bolivia, the population of alpacas is 
456,784 specimens (FAO, 2005), which represents more than $11 \%$ of the total world population of this species. The Bolivian plateau is characterized by physiographic heterogeneity with a mixture of Puna and small valley conditions, where settled mixed livestock systems of goats, sheep and camelids can be found. There are few regions in Bolivia that are appropriate for alpacas because these animals inhabit humid ecological niches. Hence, the distribution of this species is limited in Bolivia, with approximately $90 \%$ of all alpacas being found in the North and Central plateau, where rainfall exceeds $500 \mathrm{~mm} /$ year and the presence of "bofedales" allows alpacas to graze (Iñiguez and Alem, 1996). Alpacas are reared in four main regions, including Ulla Ulla in La Paz, Pacajes-Sajama, Turco in Oruro and Ayopaya in Cochabamba. The "alpaquero" system of Ulla Ulla involves a high production system that is the largest producer of fiber in the country. In the regions of Pacajes-Sajama and Turco, mixed production systems are found, and these are based on small ruminant species reared together with llamas and alpacas. After the introduction of alpacas into Cochabamba in the early 1990s, a mixed production system has most frequently been observed in this region. As a result of these production systems, Bolivian alpaca fiber is produced for the textile industry and traded through a complex network of intermediaries.

Two varieties of alpacas are commonly recognized: the Huacaya, with a short and crimped fleece, which is well adapted to harsh weather and high altitudes; and the Suri, which has longer and wavy fibers that are considered the finest fibers (Wuliji et al., 2000). In demographic terms of the worldwide alpaca population, there is a predominance of the Huacaya type of alpaca, from which $90 \%$ of alpaca fleece is processed (Morante et al., 2009). However, the concept of breeds or varieties is still preliminary for this species because alpacas and llamas are considered to be animals in the first levels of domestication (Renieri et al., 2009).

According to previous studies of the molecular characterization of South American camelids (Kadwell et al., 2001; Sarno et al., 2001; Bustamante et al., 2002; Sarno et al., 2004; Maté et al., 2005; Marin et al., 2008), it is possible to infer a marked difference in levels of genetic diversity and population structure among species and among populations within each species due to the dynamics, history and management of each population. Specifically, variable levels of genetic diversity have been reported in populations of alpacas from Perú (Rodríguez et al., 2004; Agapito et al., 2008; Paredes et al., 2011; La Manna et al., 2011) and Australia (Munyard et al., 2009).

However, to date, no studies have assessed the genetic diversity and relationships among the populations of Bolivian alpacas, which would be of great help for the development of the most appropriate management strategies for these populations. These studies may be of great importance for the future development of successful breeding strategies, mainly addressing fiber production objectives, which could be considered use in these populations as reported for other authors in Peruvian populations (Gutiérrez et al., 2009; Cervantes et al., 2010). This paper aims to explore, for the first time, the genetic diversity and

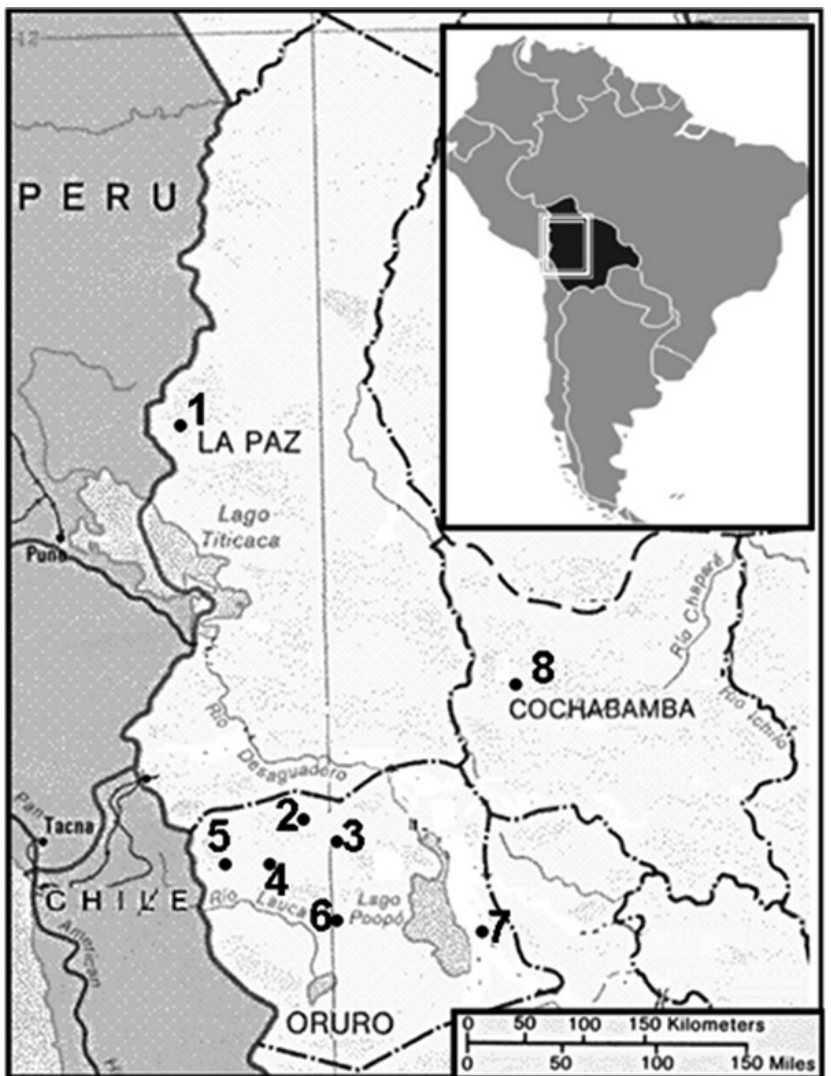

1)Ulla Ulla; 2) Curahuara; 3 ) Turco; 4) Cosapa;

5) Lagunas; 6) Poopó; 7) Challapata; 8) Ayopaya

Fig. 1. Geographical locations of the eight Bolivian alpaca populations sampled in this study.

population structure within and between Bolivian alpaca populations.

\section{Materials and methods}

\subsection{Animals}

A total of 149 alpacas from eight locations in Bolivia were sampled: Ulla Ulla $(n=30)$, Curahuara $(n=16)$, Turco $(n=18)$, Cosapa $(n=18)$ Lagunas $(n=15)$, Poopó $(n=18)$, Challapata $(n=21)$ and Ayopaya $(n=13)$ see supplemental Table S1 for details. For each population, unrelated animals were sampled from a number of flocks that ranged from 1 (Poopó) to 13 (Ulla Ulla). A representation of the geographic distribution of the corresponding parameters for each locality is provided in Fig. 1 and supplemental Table S1, respectively. Briefly, the region of Ulla Ulla is the wettest region of the Bolivian plateau (annual precipitation of $550 \mathrm{~mm}^{3}$ ), which allows for the extensive breeding of alpacas that graze on plants grown on organic soils to obtain constant moisture from the groundwater (bofedales). This region includes the largest number of alpacas in Bolivia. The Curahuara, Lagunas and Cosapa populations are close together in a region characterized by low annual precipitation $(250-330 \mathrm{~mm} /$ year $)$. The concentration of snow during freezing allows for the formation of bofedales for breeding alpacas. The Turco population is located in a region with three major topographic zones: the pampas, the hills and plains, and the intraAltiplano where the vegetation is a mix of pajonales, tolar shrubs and bofedales. The Poopó and Challapata populations are on both sides of the Poopó Lake. The Ayopaya population is located in broken terrain over a range of altitudes where annual precipitation levels are approximately $900 \mathrm{~mm} /$ year. 


\subsection{DNA isolation and genotyping}

Extraction of DNA from hair samples was performed using a modified version of the protocol based on the use of Chelex $100 \times$, as described by Woodward et al. (1994).

A total of 22 microsatellite markers previously reported in South American camelids (Lang et al., 1996; Penedo et al., 1998a,b; Bustamante et al., 2003; Obreque et al., 1999; Munyard et al., 2009) were genotyped across all of the samples included in this study see supplemental Table S2 for details about marker identities and sequences. The selection of these markers, which included 18 dinucleotide and 4 tetranucleotide microsatellites, was based on previously reported information. All the markers were genotyped at the Evolutive Biology Unit of the Institute of Molecular Biology and Biotechnology in La Paz, Bolivia. Polymerase chain reactions (PCR) in $30 \mu$ l reaction volumes containing $30 \mathrm{ng}$ of genomic DNA, $0.5 \mu \mathrm{M}$ of each primer, $0.3 \mathrm{mM}$ of dNTPs, $1 \times$ PCR buffer $(10 \times$ buffer - $50 \mathrm{mM} \mathrm{KCl}, 10 \mathrm{mM}$ Tris- $\mathrm{HCl} \mathrm{pH} 9.0$, and $0.1 \%$ Triton X-100), $1.5 \mathrm{mM}$ of $\mathrm{MgCl}_{2}$ and $0.4 \mathrm{U}$ of Taq polymerase (Promega Corp., Madison, WI, USA). The amplification conditions included an initial denaturation step at $95{ }^{\circ} \mathrm{C}$ for $5 \mathrm{~min}$, followed by 25 cycles of $94{ }^{\circ} \mathrm{C}$ for $35 \mathrm{~s}, 30 \mathrm{~s}$ at $54-56{ }^{\circ} \mathrm{C}$ (depending on the primer pair), $72{ }^{\circ} \mathrm{C}$ for $25 \mathrm{~s}$, and a final extension at $72{ }^{\circ} \mathrm{C}$ during $10 \mathrm{~min}$. The PCR products were electrophoresed on $10 \%$ polyacrylamide gels (19:1) and allele bands were detected by silver nitrate staining. Allele sizes were estimated using a 25 bp DNA Step Ladder (Promega Corp., Madison, WI, USA), and the genotypes for the samples were independently called by two examiners. Discrepancies identified via a custom-made database were double-checked and resolved.

\subsection{Genetic data analyses}

Allele frequency, the number of alleles $(A)$, observed heterozygosity $(\mathrm{Ho})$ and the expected gene diversity heterozygosity $(\mathrm{He})$ from the Hardy-Weinberg equilibrium (HWE) assumptions were calculated across different loci and subpopulations using the GENETIX 4.04 software package (Belkhir et al., 2002). Deviations from Hardy-Weinberg equilibrium (HWE) were tested using the Fisher's exact test implemented in GENEPOP version 3.3 (Raymond and Rousset, 1995). Allele frequency data were used to calculate polymorphic information content (PIC) values using CERVUS 3.0.3. We used MOLKIN 3.0 (Gutiérrez et al., 2005) to perform a bootstrapping analysis with the aim of adjusting for differences in population sample size and avoid any undesirable bias in our estimates. This also allowed us to perform a rarefaction correction (k18) to standardize allelic richness among different sample sizes populations. Genetic structuring of the Bolivian alpaca populations was analyzed by Wright's $F$ statistics. Pairwise genetic distances (Fst), inbreeding coefficients (Fis) and gene flow estimates (number of migrants in each generation, $\mathrm{Nm}$ ) were calculated using the GENETIX 4.04 software package (Belkhir et al., 2002). The possibilities of recent population bottlenecks for all eight populations under study were investigated following the two-phase model with 90\% stepwise mutation using BOTTLENECK v.2 (Cornuet and Luikard, 1996). Following Cornuet et al. (1999), significance was assessed by using the mode-shift of allele frequencies criterion (weak evidence of a recent bottleneck) and the more rigorous Wilcoxon test.

To determine the distribution of genetic diversity among and within populations, an analysis of molecular variance (AMOVA) was performed using ARLEQUIN V.3 software (Excoffier et al., 2005). Population differentiation was assessed through a factorial correspondence analysis (of individual multilocus genotypes) using GENETIX (Belkhir et al., 2002).

The genetic structure of the studied populations was investigated using the STRUCTURE software (Pritchard et al., 2000). To choose the appropriate number of inferred clusters $(K)$, we performed ten runs, fitting $K$ from 2 to 10 . All runs used a burn-in period of 20,000 iterations and a period of data collection of 10,000 iterations. The posterior probability was then calculated for each value of $K$ using the mean estimated log-likelihood of $K, L(K)$, to choose the optimal $K$. Following Evanno et al. (2005), we also calculated Delta $K(\Delta K)$, an ad hoc statistic based on the second order rate of change of the likelihood function, $L^{\prime \prime}(K)$, with respect to $K$. Graphic representation of these statistics were obtained with the web-based STRUCTURE HARVESTER software v0.6.8 (Earl and VonHoldt, 2011).

\section{Results}

\subsection{Genetic diversity}

The analysis based on 22 DNA microsatellite loci revealed a high level of genetic diversity in the analyzed resource population. A total of 258 different alleles were observed across the 149 individuals analyzed. The number of alleles per locus showed an average of 11.7, ranging from four alleles for marker P86, to 18 alleles for markers YWLL44, LCA77 and LCA56 (Table 1). The majority of the markers were highly polymorphic, with the number of detected alleles ranging between 8 and 17. The highest Ho was observed for locus LCA65 (0.86), whereas the lowest Ho was found for marker VOLP1 (0.31). The locus showing the highest He was VOLP4 (0.91), whereas VOLP1 had the lowest value for this parameter (0.45) (Table 1$)$. For the global population, and accounting for multiple tests (22 markers and 8 populations), nine out of the 22 loci analyzed were identified to be in HW disequilibrium in the global population (see Table 1). Because the maximum number of populations for which these markers were in HW disequilibrium was one, the information from all of the markers was considered in subsequent analyses of genetic differentiation. The frequency of null alleles estimated for the complete set of markers analyzed ranged from 0.022 to 0.290 . Considering all the markers under study jointly, the largest mean number of alleles per locus (MNA) was found in the Ulla Ulla population (9) (Table 2). Among all of the populations, the average Ho ranged from $0.611 \pm 0.207$ (Poopó) to $0.696 \pm 0.180$ (Turco), whereas the average He varied between $0.664 \pm 0.217$ (Poopó) and $0.743 \pm 0.170$ (Ulla Ulla) (Table 2). The PIC values ranged from 0.69 (LCA24) to 0.94 (YWLL36) (Table 2). In total, 50 private alleles (19\%) were observed, and these were distributed across 8 of the populations studied. Ulla Ulla exhibited the highest number of private alleles $(n=17)$ followed by Challapata $(n=11)$ (Table 2). However, the private alleles found in other regions showed high frequency (e.g., Curahuara for LCA56, [0.33], Poopó for P86 [0.19] and Lagunas and Cosapa for VOLP5 [0.15]).

The results of the bootstrapping analysis and the rarefaction correction did not show remarkable differences regarding the estimates of the diversity parameters reported above, with the mean allelic richness estimated for all the loci and studied populations ranging between 5 and 8 alleles. These similar results obtained after this correction support the genetic parameter estimates reported earlier and discard any possible artifact due to the different sizes of the populations studied in this work.

The coefficient of inbreeding, Fis, was estimated for each locus at the population level (Table 1 ) and individually for each population (Table 2). For the individual markers, 10 some of the Fis estimates were significant (19 positive and 3 negative), with 9 markers showing high values for this parameter. Considering the individual populations, all of the inbreeding coefficients were also positive and significantly different from zero $(P<0.05)$ except that estimated for Turco. The highest Fis values for the individual populations were observed for Lagunas, Ayopaya and Curahuara $(0.114,0.113$ and 0.111 , respectively). No significant recent 
Table 1

Genetic diversity parameters estimated for the 22 microsatellite markers analyzed in the eight alpaca populations considered in this study.

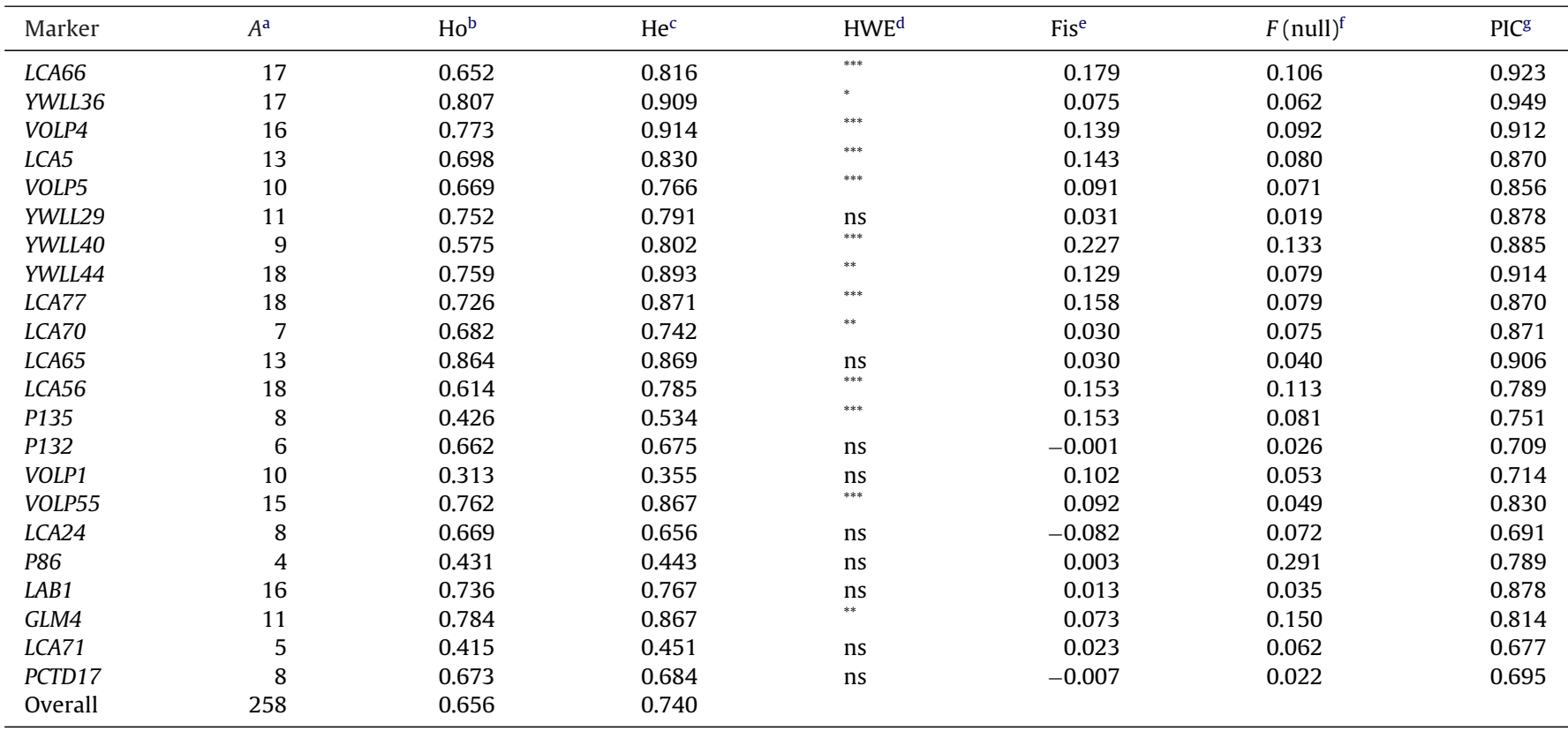

a A: number of alleles per locus.

b Ho: average observed heterozygosity.

c He: average expected heterozygosity.

d HWE: significant deviation from the Hardy-Weinberg equilibrium $(P<0.001)$.

e Fis: coefficient of inbreeding.

f $F$ (null): frequency of null alleles estimated for each locus.

g PIC: polymorphic information content.

population bottleneck was identified for any of the studied populations.

\subsection{Genetic differentiation}

Based on the eight considered subpopulations, the genetic differentiation between population pairs was low to moderate, with pairwise Fst coefficients ranging from 0.008 (Curahuara-Cosapa) to 0.077 (Poopó-Ulla Ulla and Poopó-Ayopaya) (Table 3). The alpacas from Poopó showed the largest genetic differentiation within the sampled populations. This population showed moderate to large genetic differentiation levels compared with the other populations (Fst range: 0.053-0.077), which were associated with restricted gene flows between Poopó and the other populations (Nm range: $2.97-4.49$ ). In contrast, Curahuara and Cosapa were the least differentiated populations at the genetic level (Fst $=0.008)$, and for which the highest gene flow was identified $(\mathrm{Nm}=32.54)$. The analysis of variance showed a significant and higher value within (96.14\%) than among populations (3.86\%). The Fst value calculated by this analysis suggested a moderately low genetic differentiation for the global population (Fst $=0.04)$.

Table 2

Genetic variability parameters estimated for eight populations of Bolivian alpacas based on the analysis of 22 microsatellite markers.

\begin{tabular}{|c|c|c|c|c|c|c|}
\hline Group & $n^{\mathrm{a}}$ & $\mathrm{Ho}^{\mathrm{b}}$ & $\mathrm{He}^{\mathrm{c}}$ & $\mathrm{MNA}^{\mathrm{d}}$ & $\mathrm{pA}^{\mathrm{e}}$ & Fis $^{f}$ \\
\hline Ulla Ulla & 30 & $0.678 \pm 0.158$ & $0.743 \pm 0.170$ & 9 & 17 & $0.088^{* * *}$ \\
\hline Curahuara & 16 & $0.638 \pm 0.211$ & $0.715 \pm 0.179$ & 7 & 2 & $0.111^{* * *}$ \\
\hline Turco & 18 & $0.696 \pm 0.180$ & $0.709 \pm 0.171$ & 6 & 4 & 0.019 \\
\hline Cosapa & 18 & $0.662 \pm 0.177$ & $0.718 \pm 0.178$ & 7 & 6 & $0.080^{* *}$ \\
\hline Lagunas & 15 & $0.619 \pm 0.156$ & $0.696 \pm 0.159$ & 6 & 4 & $0.114^{* * *}$ \\
\hline Poopó & 18 & $0.611 \pm 0.207$ & $0.664 \pm 0.217$ & 6 & 4 & $0.082^{* * *}$ \\
\hline Challapata & 21 & $0.683 \pm 0.196$ & $0.738 \pm 0.141$ & 7 & 11 & $0.076^{* * *}$ \\
\hline
\end{tabular}

a $n$ : sample size.

b Ho: average observed heterozygosity $( \pm S D)$.

c He: average expected heterozygosity $( \pm \mathrm{SD})$.

d MNA: mean number of alleles.

e pA: number of private alleles.

f Fis: estimates and significance of the deviation from Hardy-Weinberg equilibrium per population across the 22 loci.

${ }^{*} P<0.05$.

${ }^{* *} P<0.01$.

*** $P<0.001$. 
Table 3

Genetic differentiation parameters estimated for the eight Bolivian alpaca populations in this study based on the analysis of 22 microsatellite markers. Pair-wise genetic distances (Fst) and number of effective migrants per generation (Nm) are given above and below the diagonal, respectively.

\begin{tabular}{|c|c|c|c|c|c|c|c|c|}
\hline Locality & Ulla Ulla & Curahuara & Turco & Cosapa & Lagunas & Poopó & Challapata & Ayopaya \\
\hline Ulla Ulla & - & $0.018^{* * *}$ & $0.034^{* * *}$ & $0.027^{* * *}$ & $0.0231^{* * *}$ & $0.077^{* * *}$ & $0.018^{* * *}$ & $0.025^{* * *}$ \\
\hline Curahuara & 13.62 & - & $0.027^{* *}$ & 0.008 & 0.009 & $0.053^{* * *}$ & $0.035^{* * *}$ & $0.031^{* *}$ \\
\hline Turco & 7.02 & 8.93 & - & $0.033^{* *}$ & $0.036^{* * *}$ & $0.063^{* * *}$ & $0.056^{* * *}$ & $0.035^{* * *}$ \\
\hline Cosapa & 8.88 & 32.54 & 7.38 & - & $0.019^{* *}$ & $0.042^{* * *}$ & $0.040^{* * *}$ & $0.029^{* * *}$ \\
\hline Lagunas & 7.70 & 25.06 & 6.67 & 13.09 & - & $0.045^{* * *}$ & $0.042^{* * *}$ & $0.041^{* * *}$ \\
\hline Poopó & 2.97 & 4.49 & 3.68 & 5.72 & 5.35 & - & $0.067^{* * *}$ & $0.077^{* * *}$ \\
\hline Challapata & 13.81 & 6.87 & 4.18 & 6.00 & 5.75 & 3.48 & - & $0.029^{* * *}$ \\
\hline Ayopaya & 9.60 & 7.74 & 6.85 & 8.43 & 5.85 & 3.01 & 8.28 & - \\
\hline
\end{tabular}

Significance levels of the estimates are also provided.

${ }^{*} P<0.05$.

${ }^{* * *} P<0.01$.

${ }^{* * *} P<0.001$.

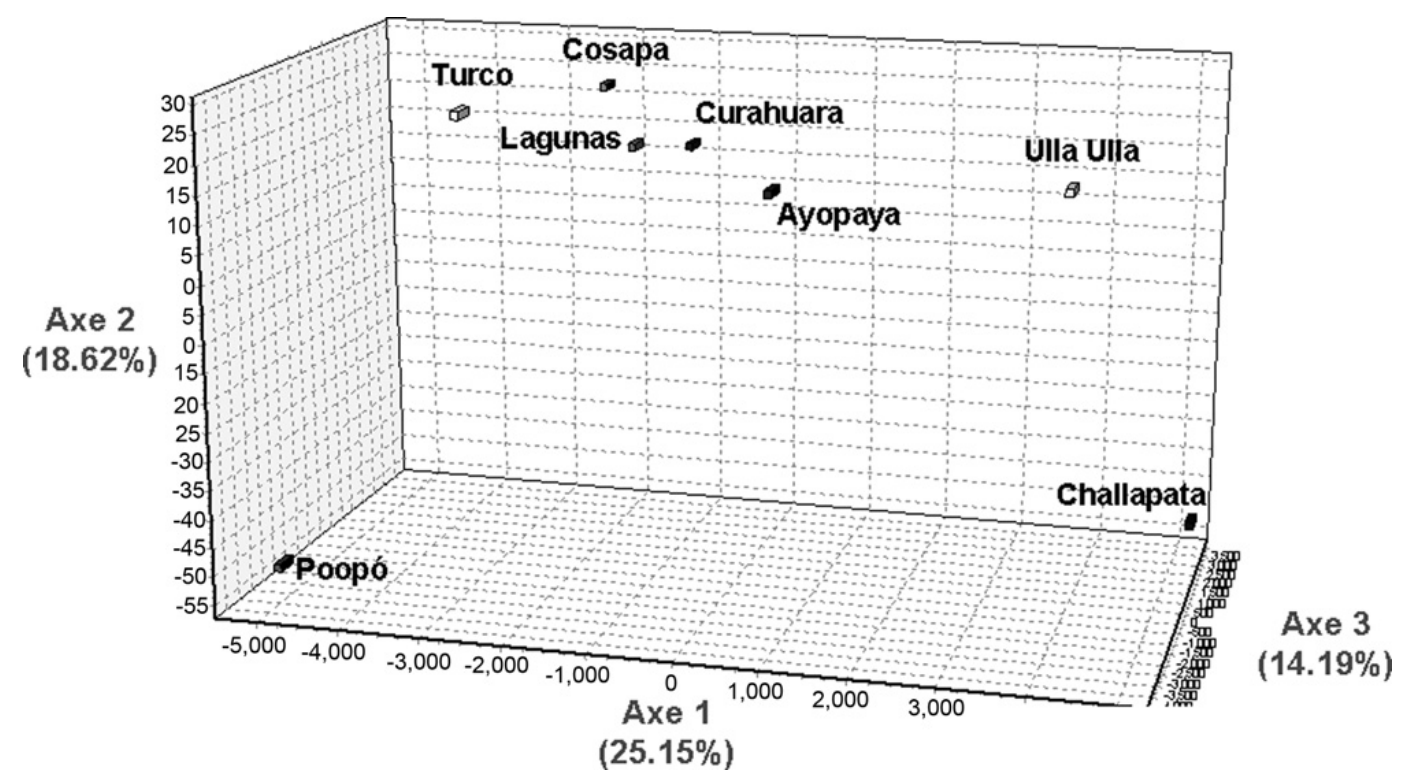

Fig. 2. Spatial representation of the eight populations of alpacas as defined by the factorial correspondence analysis described in this work. The percentage of inertia explained by each component is indicated in parentheses.

According to the factorial analysis of correspondence, the first three components combined explained $57.96 \%$ of the total genetic variation (Fig. 2). The first component explained $25.15 \%$ of the total variation and separated the Challapata and Ulla Ulla populations from the other populations, such as Ayopaya, Curahuara, Lagunas, Cosapa and Turco. The second component, which represented $18.62 \%$ of the total variation, and the third component, which represented the $14.19 \%$ of the total variation, demonstrated the isolation of the Poopó population from all of the other populations.

Bayesian analysis performed with the STRUCTURE software (Pritchard et al., 2000) indicated a clear structure in the alpaca population sample analyzed. The highest likelihood was obtained when $K$ was set to five, with the distribution of $L(K)$ showing a clear peak for $K=5$, supplementary Fig. S1a. However, using the method of Evanno et al. (2005), maximal $\Delta K$ occurred at $K=2$, supplementary Fig. S1b, with the next largest peak at $K=5$. Other authors identifying a similar discrepancy have reported maximal $\Delta K$ at $K=2$ to be an artifact resulting from markedly low likelihoods for $K=1$ (Vigouroux et al., 2008). Based on this and the biological significance of the results, $K=5$ was chosen as the final estimated number of populations. The graphical representation of the clustering outcomes that suggested $K=5$ is shown in Fig. 3, whereas the proportion of membership for each identified cluster is provided in Table 4 . The analysis assigned the Poopó and Turco populations to two independent clusters (clusters 4 and 5, respectively), with Poopó being the most differentiated population. Ulla Ulla and Challapata showed

Table 4

Proportion of membership for each of the eight alpaca populations studied across the five clusters identified through the assignment analysis performed in this study.

\begin{tabular}{llllll}
\hline \multirow{2}{*}{ Population } & \multicolumn{5}{l}{ Cluster } \\
\cline { 2 - 6 } & 1 & 2 & 3 & 4 & 5 \\
\hline Ulla Ulla & 0.552 & 0.084 & 0.264 & 0.017 & 0.083 \\
Curahuara & 0.163 & 0.419 & 0.048 & 0.142 & 0.227 \\
Turco & 0.051 & 0.132 & 0.025 & 0.049 & 0.744 \\
Cosapa & 0.073 & 0.545 & 0.056 & 0.105 & 0.221 \\
Lagunas & 0.165 & 0.412 & 0.047 & 0.114 & 0.262 \\
Poopó & 0.023 & 0.032 & 0.018 & 0.892 & 0.034 \\
Challapata & 0.341 & 0.123 & 0.479 & 0.026 & 0.030 \\
Ayopaya & 0.159 & 0.161 & 0.231 & 0.064 & 0.386 \\
\hline
\end{tabular}




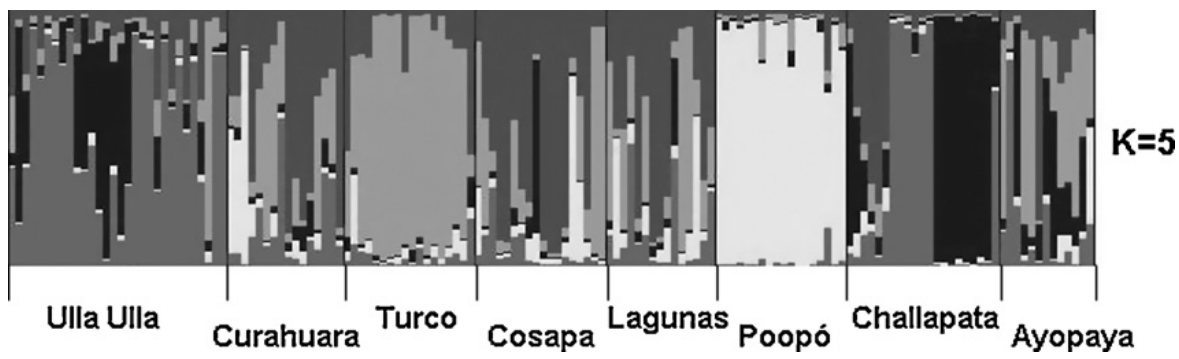

Fig. 3. Graphical representation of the clustering outcomes suggested by the Bayesian analysis performed to assess the structure of the studied populations at $K=5$. Each color represents one cluster, and the length of the colored segment shows the individual's estimated proportion of membership in that cluster. Black lines separate the individuals of the different populations.

the influence of two of the other clusters, clusters 1 and 3 , although in Ulla Ulla, cluster 1 was predominant. The Ayopaya population was shown to be substantially influenced by the Turco-related cluster (cluster 5), followed by cluster 3, and with minor influences from the other clusters. The last cluster identified (cluster 2) had the largest proportion of its membership in the Cosapa population, although this population also showed certain influences from the Turco- and Poopó-related clusters. The Curahura and Lagunas populations showed a mixed structure similar to that observed for the Cosapa population, but with a slightly lower membership proportion of cluster 2 .

\section{Discussion}

\subsection{Genetic variability}

A representative sample of Bolivian alpacas $(n=149)$ was considered in this experiment to study genetic diversity based on the analysis of 22 microsatellite markers. The sample included animals from eight different localities related to the most important alpaca breeding regions in Bolivia, and these animals were distributed across a variety of climatic, topographical and geographical zones in this country.

All of the results described herein revealed high levels of genetic variability comparable to previous studies performed on different alpaca populations from Peru (Agapito et al., 2008; Paredes et al., 2011; La Manna et al., 2011) and Australia (Munyard et al., 2009).

For the overall population, nine out of the 22 markers analyzed showed significant deviation from HWE (Table 1). The lack of correlation observed between deviation from HWE and the occurrence of null alleles suggests the existence of a population subdivision (Wahlund's effects), likely due to a reduced effective size within the flocks of the studied populations.

Based on the lack of significant evidence for recent bottlenecks in all of the studied populations, it seems that the significant Fis values identified in seven out of the eight studied populations may be the result of inappropriate breeding practices, such as the use of reproductive males within the same herd. Especially for the Lagunas, Ayopaya and Curahuara populations, the high levels of inbreeding should be carefully considered. It is known that high inbreeding levels in livestock populations are related to inbreeding depression and a reduction in the average phenotypic values of the traits of economic interest (Falconer and Mackay, 1996). Moreover, high levels of inbreeding are associated with the frequent emergence of recessive genetic defects. Related to this observation, malformations and low fertility have already been described in Peruvian alpaca populations (Reyna, 2005). In the Ulla Ulla region, which is an important alpaca production area, lower levels of inbreeding than those reported here would be expected due to the continued introduction of improved males from Perú (Iñiguez and Alem, 1996). The inbreeding estimates presented herein for this population are lower to those reported by Paredes et al. (2011) in Southern Peruvian alpacas (Fis $=0.1487$ ), which are reared close to the Ulla Ulla region. However, the lowest inbreeding levels found in this study were associated with the Turco population and may be explained by the mating system followed by the breeders from this region, which is based on a greater exchange of reproductive males between producers and the use of males from the Centro de Machaje Tika-Uta (Rodriguez and Quispe, 2007). Nevertheless, because of the limited number of samples used to obtain the Fis estimated here presented future studies based on larger population sized would be desirable for an appropriate assessment of the inbreeding levels in Bolivian alpaca populations.

\subsection{Population structure}

Information on the genetic variation estimated through the analysis of molecular variance showed that most of the genetic variation was found within populations, whereas, the between-population variation was $3.86 \%$.

Several of the populations included in this study are related to one of the four main alpaquero systems found in Bolivia and are associated with the regions of Ulla Ulla (Ulla Ulla population), Pacajes-Sajama (Cosapa, Lagunas and Curahuara populations), Turco (Turco population) and Cochabamba (Ayopaya population), whereas the populations of Challapata and Poopó are not directly associated with any of these established management systems (FAO, 2005). Interestingly, we found a certain correspondence between the productive classification of the populations studied and their genetic differentiation. Hence, low pairwise Fst and high gene flow estimates were found among the three populations related to the Pacajes-Sajama alpaquero system in concordance with its close geographical location in Central Altiplano. Moreover, based on the correspondence analysis, Lagunas, Cosapa and Curahuara 
populations appear to share a common genetic history, probably based on the use of the same breeding practices associated with the corresponding alpaquero system.

Interestingly, the Ulla Ulla population showed the largest number of private alleles, which may be a consequence of the breeding strategy that is used in this production region which is based on the use of reproductive males from Peru (Iñiguez and Alem, 1996).

Poopó alpacas appeared to be the most differentiated population, and it showed the lowest Nm compared with the other populations. This was confirmed by the factorial correspondence and structure analyses, and was also supported by the results obtained after the unequal samples correction, which would suggest that Poopó has maintained an important genetic isolation from all of the other studied populations. Although this result is based on the sampling in a single flock, and would need to be confirmed through a larger population sampling, the genetic isolation identified here for Poopó agrees with the fact that this is not a traditional alpaquera region and is not frequently involved in the exchange of animals with other populations. The rest of the studied populations, Ayopaya, Challapata and Turco, did not show a remarkable genetic differentiation according to our analyses. In general, the high number of private alleles $(\mathrm{p} A=50)$ found in the alpaca sampled populations supports that a genuine genetic differentiation exists among the studied subpopulations.

The Bayesian assignment test indicated that the eight populations of Bolivian alpacas are not panmictic and can be assigned to five different subpopulations. This analysis supported the isolation of Poopó, as was previously suggested by the genetic differentiation and factorial correspondence analyses. The Turco population, which was also clearly differentiated from the other populations, appeared to have an influence on the Ayopaya, Cosapa, Lagunas and Curahuara populations. This relationship can be partly explained by the use of males from the Turco to neighboring regions in Oruro (Rodríguez and Quispe, 2007).

Based on the relevance of the traditional alpaquero production system linked to the Ulla Ulla region and the general exploitation of animals from this region across all the regions in Bolivia, we would expect an influence of the two Ulla Ulla-related clusters on the rest of the studied populations. However, this influence was only observed on the Challapata population and, to a lesser extent, on the Ayopaya population and the populations related to new alpaquero systems, such as Turco and the Cosapa-Lagunas-Curahuara trio, although these are becoming clearly differentiated from the clusters originally represented in the Ulla Ulla population. Similar to the results from the rest of the analyses, the population structure analysis showed that the populations of Lagunas, Cosapa and Curahuara share a common genetic history probably based on the use of the same breeding practices associated with the Pacajes-Sajama alpaquero system.

On the other hand, Ayopaya was the population that showed a more similar distribution of the five cluster populations, although the establishment of the Ayopaya population has been reported to be based on the selection of animals from the Ulla Ulla region 20 years ago (Markemann and Valle Zárate, 2010). Overall, this study provides the first survey of genetic diversity in Bolivian alpaca populations. The information reported here may be of great value for the development of breeding strategies that could be considered in these populations.

\section{Acknowledgments}

We gratefully acknowledge the financial support received from the AECID by projects A/010497/07 and A/017114/08. Julia Barreta's scholarship has been provided by a MAE-AECID fellowship (Spanish Agency for International Development Cooperation; Spanish Ministry of Foreign Affairs and Cooperation). Financial support from Swedish Cooperation Agency (SIDA) to UMSA is also acknowledged.

\section{Appendix A. Supplementary data}

Supplementary data associated with this article can be found, in the online version, at doi: 10.1016/j.smallrumres.2012.03.002.

\section{References}

Agapito, J., Rodríguez, J., Herrera-Velit, P., Timoteo, O., Rojas, P., Boettcher, P.J., García, F., Espinoza, J.R., 2008. Parentage testing in alpacas (Vicugna pacos) using semi-automated fluorescent multiplex PCRs with 10 microsatellite markers. Anim. Genet. 39, 201-203.

Belkhir, K., Borsa, P., Goudet, J., Chikhi, L., Bonhomme, F., 2002. GENETIX Logiciel Sous Windows TM Pour la Génétique des Populations. Laboratoire Génome, Populations, Interactions CNRS UMR 5000. Université de Montpellier II, Montpellier, France.

Bustamante, A., Zambelli, A., de Lamo, D., von Thungen, J., Vidal Rioja, L., 2002. Genetic variability of guanaco and llama populations in Argentina. Small Rumin. Res. 4, 101-497.

Bustamante, A., Mate, M.L., Zambelli, A., Vidal-Rioja, L., 2003. Isolation and characterization of 10 polymorphic dinucleotide microsatellite markers for llama and guanaco. Mol. Ecol. Notes 3, 68-69.

Cervantes, I., Perez-Cabal, M.A., Morante, R., Burgos, A., Salgado, C., Nieto, B., Goyache, F., Gutiérrez, J.P., 2010. Genetic parameters and relationships between fibre and type traits in two breeds of Peruvian alpacas. Small Rumin. Res. 88, 6-11.

Cornuet, J.M., Luikard, G., 1996. Description and power analysis of two tests for detecting recent population bottlenecks from allele frequency data. Genetics 144, 2001-2014.

Cornuet, J.M., Piry, S., Luikart, G., Estoup, A., Solignac, M., 1999. New methods employing multilocus genotypes to select or exclude populations as origins of individuals. Genetics 153, 1989-2000.

Earl, D.A., VonHoldt, B.M., 2011. STRUCTURE HARVESTER: a website and program for visualizing STRUCTURE output and implementing the Evanno method. Conserv. Genet. Resour., doi:10.1007/s12686-0119548-7.

Excoffier, L., Laval, G., Schneider, S., 2005. Arlequin ver.3.0: an integrated software package for population genetics data analysis. Evol. Bioinform. Online 1, 47-50.

Evanno, G., Regnaut, S., Goudent, J., 2005. Detecting the number of clusters of individuals using the software STRUCTURE: a simulation study. Mol. Ecol. 14, 2611-2620.

Falconer, D.S., Mackay, T.F.C., 1996. Introduction to Quantitative Genetics, 4th ed. Longmans Green, Harlow, Essex, UK.

FAO (Food Agriculture Organization), 2005. Situación actual de los camélidos sudamericanos en Bolivia., http://www.cites.org/eng/cop/ 14/prop/E14-P08.pdf.

Gutiérrez, J.P., Royo, L.J., Álvarez, I., Goyache, F., 2005. MolKin v2.0: a computer program for genetic analysis of populations using molecular coancestry information. J. Hered. 96, 718-721.

Gutiérrez, J.P., Goyache, F., Burgos, A., Cervantes, I., 2009. Genetic analysis of six production traits in Peruvian alpacas. Livestock Sci. 123, 193-197.

Iñiguez, L.C., Alem, R., 1996. Role of camelids as means of transportation and exchange in the Andean region of Bolivia. World Anim. Rev. 86, $12-21$. 
Kadwell, M., Fernández, M., Stanley, H.F., Baldi, R., Wheeler, J.C., Rosadio, R., 2001. Genetic analysis reveals the wild ancestors of the llama and alpaca. Proc. R. Soc. Lond. B 268, 2575-2584.

La Manna, V., La Terza, A., Dharaneedharam, S., Ghezzi, S., Arumugam, S., Apaza, N., Huanca, T., Bozzi, R., Renieri, C., 2011. A microsatellite study on the genetic distance between Suri and Huacaya phenotypes in Peruvian alpaca (Vicugna pacos). In: Fibre Production in South American Camelids and Other Fibre Animals. Wageningen Academic Publishers, pp. 151-157.

Lang, K.D., Wang, Y., Plante, Y., 1996. Fifteen polymorphic dinucleotide microsatellites in llamas and alpacas. Anim. Genet. 27, 293.

Maté, M.L., Bustamante, A.V., Giovambattista, G., Delamo, D., Lamas, H. Thungen Von, J., Zambelli, A., Vidal-Rioja, L., 2005. Genetic diversity and differentiation of guanaco populations from Argentina inferred from microsatellite data. Anim. Genet. 36, 316-321.

Marin, J.C., Spotorno, A.E., González, B.A., Bonacic, C., Wheeler, J.C., Casey, C.S., Bruford, M.W., Palma, R.E., Poulin, E., 2008. Mitochondrial DNA variation and systematics of the guanaco (Lama guanicoe, Artiodactyla: Camelidae). J. Mammal. 89, 269-281.

Markemann, A., Valle Zárate, A., 2010. Traditional llama husbandry and breeding management in the Ayopaya region. Bolivia. Anim. Health Prod. 42, 79-87.

Morante, R., Goyache, F., Burgos, A., Cervantes, I., Perez-Cabal, M.A., Gutierrez, J.P., 2009. Genetic improvemenet for alpaca fibre production in the Peruvian Altiplano: the Pacomara experience. Anim. Genet. Resour. Inf. $45,37-43$.

Munyard, K.A., Ledger, J.M., Lee, C.Y., Babra, C.D., Groth, M., 2009. Characterization and multiplex genotyping of alpaca tetranucleotide microsatellite markers. Small Rumin. Res., doi:10.1016/j.smallrumres.2009.07.012.

Obreque, V., Mancilla, R., Garcia-Huidobro, J., Cothran, E.G., Hinrichsen, P., 1999. Thirteen new dinucleotide microsatellites in Alpaca. Anim. Genet. 30, 397-398.

Paredes, M., Machaca, J., Azor, P.J., Alonso-Moraga, A., Membrillo, A., Muñoz-Serrano, A., 2011. Genetic differentiation of six Peruvian alpaca populations. In: Fibre Production in South American Camelids and Other Fibre Animals. Wageningen Academic Publishers, pp. 161-166.

Penedo, M.C., Caetano, A.R., Cordova, K.I., 1998a. Microsatellite markers for South American camelids. Anim. Genet. 29, 411-412.
Penedo, M.T.C., Caetano, A.R., Cordova, K., 1998b. Eight microsatellite markers for South American camelids. Anim. Genet. 30, 161-168.

Pritchard, J.K., Stephens, M., Donnelly, P.J., 2000. Inference of population structure using multilocus genotype data. Genetics 155, 945-959.

Raymond, M., Rousset, F., 1995. Genepop (version 1.2), population genetics software for exact tests and ecumenicism. J. Hered. 86, 248-249.

Renieri, C., Frank, E.N., Rosati, A.Y., Antonini, Y.M., 2009. Definición de razas en llamas y alpacas. Anim. Genet. Resour. Inf. 45, 45-54.

Reyna, J., 2005. Alpaca Breeding in Peru and Perspectives for the Peru. Centre for Advanced Technologies in Animal Genetics and Reproduction, Faculty of Veterinary Science, University of Sydney NSW, Alpacas Australia, Alpacas New Zealand, World Alpacas, http://www. elitealpacabreedingsystems.com/library/AlpacaBreedingPeru.pdf.

Rodriguez, C.T., Quispe, J.L., 2007. Domesticated camelids, the main animal genetic resources of pastoral system in the region of Turco, Bolivia. In: Tempelman, K.A., Cardellino, R.A. (Eds.), People and Animals. FAO, Rome.

Rodríguez, J., Wheeler, J., Dodd, C., Bruford, M., Rosadio, R., 2004. Determinación de parentesco en alpacas (Vicugna pacos) por medio del análisis del ADN microsatélite. Rev. Inv. Vet. Perú 15 (2), 113-119.

Sarno, R.J., Franklin, W.L., Oǐbrien, S.J., Johnson, W.E., 2001. Patterns of mtDNA and microsatellite variation in an island and mainland population of guanacos in southern Chile. Anim. Conserv. 4, 93-101.

Sarno, R.J., Villalba, L., Bonacic, C., Gonzalez, B., Zapata, B., Mac Donald, D.W., O'Brien, S.J., Jonson, W.E., 2004. Phylogeography and subspecies assessment of vicuñas in Chile and Bolivia utilizing mtDNA and microsatellite markers: implications for vicuña conservation and management. Conserv. Genet. 5, 89-102.

Vigouroux, Y., Glaubitz, J.C., Matsuoka, Y., Goodman, M.M., Sánchez, G.J., Doebley, J., 2008. Population structure and genetic diversity of new world maize races assessed by DNA microsatellites. Am. J. Bot. 95 (10), 1240-1253.

Woodward, S.R., King, M.J., Chiu, N.M., Kuchar, M.J., Griggs, C.W., 1994. Amplification ancient nuclear DNA from teeth and soft tissues. PCR Methods and Applications, vol. 13, pp. 244-247.

Wuliji, T., Davis, G.H., Dodds, K.G., Turner, P.R., Andrews, R.N., Bruce, G.D., 2000. Production performance, repeatability and heritability estimates for live weigh, fleece weight and fiber characteristics of alpacas in New Zealand. Small Rumin. Res. 37, 189-201. 


\section{Supplementary Material}

\section{Supplementary Table S1}

4 The Bolivian alpaca populations sampled in this work. For each sampled population, the

5 corresponding department and geographical location are indicated together with the

6 number of flocks and samples included in the study (n). The numbers of females "F" and

7 males " $M$ " samples are indicated in parentheses.

8

\begin{tabular}{|c|c|c|c|c|c|c|c|}
\hline Locality & Department & Coord & inates & Geographical & Altitude & $\mathrm{n}$ & Flocks \\
\hline Ulla Ulla & $\mathrm{La} \mathrm{Paz}$ & $14^{\circ} 59^{\prime} 50^{\prime \prime} \mathrm{S}$ & $69^{\circ} 17^{\prime} 22.9^{\prime \prime}$ & 341 & 4381 & $\begin{array}{c}30 \\
(22 \mathrm{~F}, 8 \mathrm{M})\end{array}$ & 13 \\
\hline Curahuara & Oruro & $17^{\circ} 51 ' 22.3^{\prime S S}$ & $68^{\circ} 25^{\prime} 30.1^{\prime \prime}$ & 129 & 3926 & $\begin{array}{c}16 \\
(14 \mathrm{~F}, 2 \mathrm{M})\end{array}$ & 7 \\
\hline Turco & Oruro & $18^{\circ} 11^{\prime} 44.6^{\prime \prime S}$ & $68^{\circ} 09^{\prime} 10.6^{\prime \prime}$ & 194 & 3838 & $\begin{array}{c}18 \\
(18 \mathrm{~F})\end{array}$ & 2 \\
\hline Cosapa & Oruro & $18^{\circ} 11 ' 31.7^{\prime S S}$ & $68^{\circ} 57^{\prime} 38.8^{\prime \prime}$ & 125 & 3899 & $\begin{array}{c}18 \\
(18 \mathrm{~F})\end{array}$ & 4 \\
\hline Lagunas & Oruro & $18^{\circ} 11^{\prime} 17.9^{\prime \prime}$ & $68^{\circ} 57^{\prime} 42.5^{\prime \prime}$ & 138 & 4157 & $\begin{array}{c}15 \\
(15 F)\end{array}$ & 4 \\
\hline Poopó & Oruro & - & - & 155 & 3743 & $\begin{array}{c}18 \\
(17 \mathrm{~F}, 1 \mathrm{M})\end{array}$ & 2 \\
\hline Challapata & Oruro & $18^{\circ} 49^{\prime} 42^{\prime \prime}$ & $66^{\circ} 45^{\prime} 1.9^{\prime \prime}$ & 153 & 3734 & $\begin{array}{c}21 \\
(19 \mathrm{~F}, 2 \mathrm{M})\end{array}$ & 3 \\
\hline Aуорауа & Cochabamba & $18^{\circ} 11 ' 31.7^{\prime \prime S}$ & $68^{\circ} 57^{\prime} 38.8^{\prime \prime}$ & 198 & 3150 & $\begin{array}{c}13 \\
(8 \mathrm{~F}, 5 \mathrm{M})\end{array}$ & 5 \\
\hline
\end{tabular}

9

10

11 


\section{Supplementary Table S2}

13 List of primers used for amplification of the microsatellite markers studied in this work.

\begin{tabular}{|c|c|c|c|c|c|}
\hline Loci & $\begin{array}{l}\text { Range } \\
\text { (bp) }\end{array}$ & Sequence & $\begin{array}{l}\text { Genomic } \\
\text { libraries }\end{array}$ & $\begin{array}{l}\text { Described in the } \\
\text { species }\end{array}$ & Author \\
\hline LCA66 & $220-262$ & $\begin{array}{l}\text { GTGCAGCGTCCAAATAGTCA } \\
\text { CCAGCATCGTCCAGTATTCA }\end{array}$ & llama & llama, alpaca, guanaco & Penedo et al. (1998b) \\
\hline YWLL 36 & $142-178$ & $\begin{array}{l}\text { AGTCTTGGTGTGGTGGTAGAA } \\
\text { TGCCAGGATACTGACAGTGAT }\end{array}$ & llama & llama, alpaca & Lang et al. (1996) \\
\hline VOLP 4 & $224-256$ & $\begin{array}{l}\text { GCATTTCTCCGTAATCATTG } \\
\text { TGACACCTTTTGTTTCCATT }\end{array}$ & alpaca & alpaca & Obreque et al. (1999 \\
\hline LCA 5 & $185-213$ & $\begin{array}{l}\text { TAAGTCCAGCCCCACACTCA } \\
\text { GGTGAAGGGGCTTGATCTTC }\end{array}$ & llama & llama, alpaca, guanaco & Penedo et al.1998a \\
\hline VOLP5 & $130-177$ & $\begin{array}{l}\text { ACTTAATCACCTGGATGTAT } \\
\text { ATATGGTTCACTGTGTTTACT }\end{array}$ & alpaca & alpaca & Obreque et al.1998 \\
\hline YWLL29 & $212-232$ & $\begin{array}{l}\text { GAAGGCAGGAGAAAAGGTAG } \\
\text { CAGAGGCTTAATAACTTGCAG }\end{array}$ & llama & llama, alpaca & Lang et al. (1996) \\
\hline YWLL 40 & $178-257$ & $\begin{array}{l}\text { CACATGACCATGTCCCCTTAT } \\
\text { CCAGTGACAGTGTGGACTTAAGA }\end{array}$ & llama & llama, alpaca & Lang et al. (1996) \\
\hline YWLL 44 & $84-126$ & $\begin{array}{l}\text { CTCAACAATGCTAGGACCTTGG } \\
\text { GAGAACACAGGCTGGTGAATA }\end{array}$ & llama & llama, alpaca & Lang et al. (1996) \\
\hline LCA 77 & $163-267$ & $\begin{array}{l}\text { TGTTGACTAGAGCCTTTTCTTCTTT } \\
\text { GGGCAAGAGAGACTGACTGG }\end{array}$ & llama & llama, alpaca, guanaco & Penedo et al. (1998b) \\
\hline LCA 70 & $171-221$ & $\begin{array}{l}\text { TTCTGATGTATGGCATAGCGA } \\
\text { TGGGGGTAAGAGCAGGATAA }\end{array}$ & llama & llama, alpaca, guanaco & Penedo et al. (1998b) \\
\hline LCA 65 & $150-191$ & $\begin{array}{l}\text { TTTTTCCCCTGTGGTTGAAT } \\
\text { AACTCAGCTGTTGTCAGGGG }\end{array}$ & llama & llama, alpaca, guanaco & Penedo et al. (1998b) \\
\hline LCA 56 & $127-167$ & $\begin{array}{l}\text { ATGGTGTTTACAGGGCGTTG } \\
\text { GCATTACTGAAAAGCCCAGG }\end{array}$ & llama & llama, alpaca, guanaco & Penedo et al. (1998b) \\
\hline P135 & $208-224$ & $\begin{array}{l}\text { TGAATACAGAGGTTTCTGGCTCT } \\
\text { CACCTCCCTAAGGCCTCTTC }\end{array}$ & alpaca & alpaca & Munyard et al. (2009) \\
\hline P132 & $71-105$ & $\begin{array}{l}\text { CAGAGGAGGGACCACTAATGCTGGC } \\
\text { GGGGCAAGTGAAGTGAGTGAAATGG }\end{array}$ & alpaca & alpaca & Munyard et al. (2009) \\
\hline VOLP 1 & $214-256$ & $\begin{array}{l}\text { CCCATTGGCGATTATTTAGG } \\
\text { AACAGGGGTAACAAACAGGAC }\end{array}$ & alpaca & alpaca & Obreque et al. (1999) \\
\hline VOLP 55 & $159-201$ & $\begin{array}{l}\text { AGTTACCTTGTTTTAACCTAT } \\
\text { GACTTACTATGTGCCAATC }\end{array}$ & alpaca & alpaca & Obreque et al. (1999) \\
\hline LCA 24 & $110-126$ & $\begin{array}{l}\text { ACTCACGGGTGACATACAGTG } \\
\text { GAGCAGTGTTTGGTTTGCATT }\end{array}$ & llama & llama, alpaca & Penedo et al. (1998a) \\
\hline P86 & $143-233$ & $\begin{array}{l}\text { TTCCTTTCATTTGTCCACTC } \\
\text { TAGACCAGAAGTGTGGAAGG }\end{array}$ & alpaca & alpaca & Munyard et al. (2009) \\
\hline$L A B 1$ & $155-189$ & $\begin{array}{l}\text { AGAGGATCAATCCCTCTGAGAT } \\
\text { ATTAGAGGCCAGTATAACAATC }\end{array}$ & llama & llama, guanaco & Bustamante et al. (2003) \\
\hline GLM 4 & 187-209 & $\begin{array}{l}\text { TGAAGGAATGCAGATGAGAAGC } \\
\text { TAGCTACAAACTTCCATGACA }\end{array}$ & llama, guanaco & llama, guanaco & Bustamante et al. (2003) \\
\hline LCA71 & $136-150$ & $\begin{array}{l}\text { CAGACATATAAnGTGTATCCGTATCTA } \\
\text { TTCAGTGTTTCCTCGCAATG }\end{array}$ & Llhama alpaca, guanac & 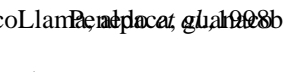 & Penedo et al. (1998b) \\
\hline PCTD 17 & 191-296 & $\begin{array}{l}\text { CCCTCTCACCTGTCTACTTG } \\
\text { GTATTCTGGCATTGGTTTGT }\end{array}$ & alpaca & alpaca & Munyard et al. (2009) \\
\hline
\end{tabular}


19 Supplementary Figure S1.

20 Graphical representation of the results of the structure population analysis used to

21 determine the true number of clusters $(\mathrm{K})$ of the alpaca populations analyzed in this work.

22 a) Mean likelihood L (K) ( \pm SD) over 20 runs for each K value tested; b) Delta K curve

23 estimated according to Evanno et al. (2005). Graphics obtained with the STRUCTURE

24 HARVESTER software v0.6.8 (Earl and VonHoldt, 2011). 
a)

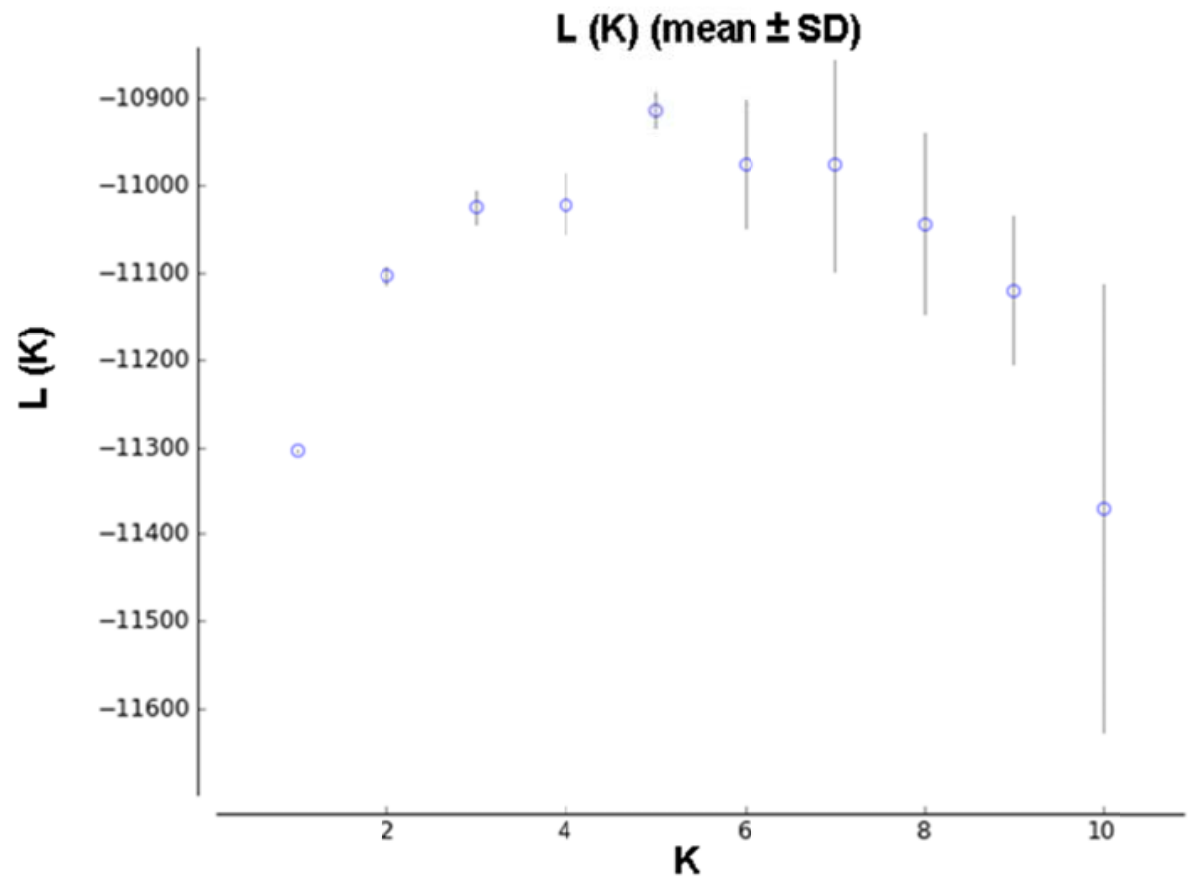

b)

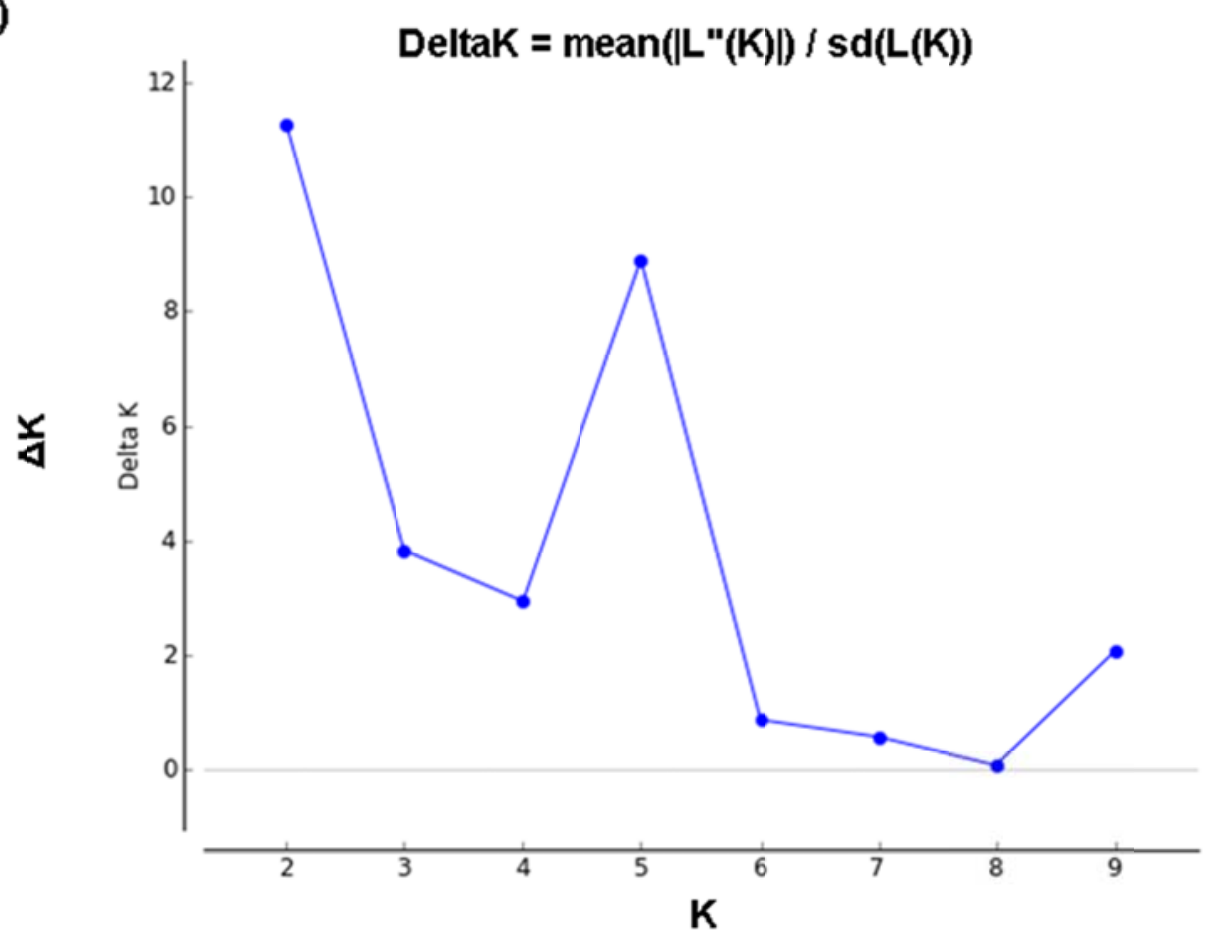


ANALYSIS OF MITOCHONDRIAL DNA IN BOLIVIAN LLAMA, ALPACA AND VICUNA POPULATIONS: A CONTRIBUTION TO THE PHYLOGENY OF THE SOUTH AMERICAN CAMELIDS.

Barreta J, Gutiérrez-Gil B, Iñiguez V, Saavedra V, Chiri R, Latorre E, Arranz JJ.

Animal Genetics. doi: 10.1111/j.1365-2052.2012.02376.x. (En prensa). 



\title{
Analysis of mitochondrial DNA in Bolivian Ilama, alpaca and vicuna populations: a contribution to the phylogeny of the South American camelids
}

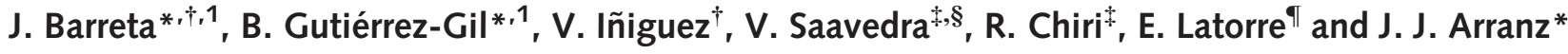 \\ *Departamento de Producción Animal, Facultad de Veterinaria, Universidad de León, 24071, León, Spain. †Instituto de Biología Molecular y \\ Biotecnología, Universidad Mayor de San Andrés (UMSA), La Paz, Bolivia. "Centro Experimental Agropecuario Condoriri, Facultad de \\ Ciencias Agrarias y Veterinarias, Universidad Técnica de Oruro, Oruro, Bolivia. ${ }^{\S}$ BANCAMEL-INIAF, Oruro, Bolivia. "INIA, Centro \\ Experimental Kampenaike, Angamos 34, Punta Arenas, Chile
}

\section{Summary}

\begin{abstract}
The objectives of this work were to assess the mtDNA diversity of Bolivian South American camelid (SAC) populations and to shed light on the evolutionary relationships between the Bolivian camelids and other populations of SACs. We have analysed two different mtDNA regions: the complete coding region of the MT-CYB gene and 513 bp of the D-loop region. The populations sampled included Bolivian llamas, alpacas and vicunas, and Chilean guanacos. High levels of genetic diversity were observed in the studied populations. In general, MT-CYB was more variable than D-loop. On a species level, the vicunas showed the lowest genetic variability, followed by the guanacos, alpacas and llamas. Phylogenetic analyses performed by including additional available mtDNA sequences from the studied species confirmed the existence of the two monophyletic clades previously described by other authors for guanacos $(G)$ and vicunas $(V)$. Significant levels of mtDNA hybridization were found in the domestic species. Our sequence analyses revealed significant sequence divergence within clade G, and some of the Bolivian llamas grouped with the majority of the southern guanacos. This finding supports the existence of more than the one llama domestication centre in South America previously suggested on the basis of archaeozoological evidence. Additionally, analysis of D-loop sequences revealed two new matrilineal lineages that are distinct from the previously reported $\mathrm{G}$ and $\mathrm{V}$ clades. The results presented here represent the first report on the population structure and genetic variability of Bolivian camelids and may help to elucidate the complex and dynamic domestication process of SAC populations.
\end{abstract}

Keywords domestication, hybridization, mitochondrial DNA, population diversity, South American camelids.

\section{Introduction}

Andean countries are the principal location where South American camelids (SACs) are found, which include guanacos (Lama guanicoe; Muller, 1776), vicunas (Vicugna vicugna; Molina, 1782), llamas (Lama glama; Linnaeus, 1758) and

Address for correspondence

Juan-José Arranz, Departamento de Producción Animal, Facultad de Veterinaria, Universidad de León, 24071 León, Spain.

E-mail: jjarrs@unileon.es

${ }^{1}$ These two authors contributed equally to this work.

Accepted for publication 5 March 2012 alpacas (Lama pacos; Linnaeus, 1758; suggested as Vicugna pacos by Kadwell et al. 2001). Guanacos and vicunas exist in the wild and can be sedentary or migratory, whereas the other two species are domestic. Most of the world's guanacos are found in Argentina (approximately 91\% of the total population) and Chile (9\%) (González et al. 2006). This species exhibits the widest geographical distribution among SACs $\left(8-55^{\circ} \mathrm{S}\right)$. Vicunas live in the highlands of the Andes at elevations of 3000 and $4300 \mathrm{~m}\left(9^{\circ} 30^{\prime}-29^{\circ} \mathrm{S}\right)$ and are found in Peru (57\%), Bolivia (21\%) and Argentina (16\%); additionally, a minor portion of the population is found in Chile (FAO 2005). The domesticated species, llamas and alpacas, can be found throughout the entire Andean region. However, the llama has a wider geographical distribution 
$\left(2-27^{\circ} \mathrm{S}\right)$ than the alpaca, which exhibits a restricted distribution $\left(8-20^{\circ} \mathrm{S}\right)$. Peru has the largest population of alpacas $(86 \%)$, and Bolivia is home to the greatest number of llamas (66\% of the total population), with 2.5 million individuals. Bolivia also contains the second largest populations of alpacas (approximately 400000 individuals) and vicunas (approximately 63000 individuals). The number of Bolivian guanacos is approximately $<50$ individuals (Cuéllar et al. 2002). The majority of the SACs are located in four regions of Bolivia: Oruro, Potosí, La Paz and Cochabamba. The Bolivian camelid population is growing annually at a rate of approximately $2.1 \%$ for llamas and $2.7 \%$ for alpacas (MACA 2003).

Studies of partial mtDNA sequences have been carried out in SAC populations, with a special focus on specimens from Chile, Argentina and Peru (Stanley et al. 1994; Kadwell et al. 2001; Sarno et al. 2001, 2004; Wheeler et al. 2006; Marin et al. 2007b; Marín et al. 2008). Overall, these studies confirm that Lama and Vicugna are valid genera that separated 2-3 million years ago (Wheeler et al. 2006). Furthermore, this research suggests that each genus contains two species: a wild ancestor and a corresponding domesticated descendant. Hence, the alpaca is considered to be the descendant of the vicuna, whereas the llama is considered to be the descendant of the guanaco (Stanley et al. 1994; Palma et al. 2001; Wheeler et al. 2006; Marin et al. 2007a). This hypothesis is supported by the morphological appearance of these species (Yacobaccio 2004). Archaeozoological evidence suggests that these evolutionary events occurred in the Central Peruvian Andes between 7000 and 6000 years ago (reviewed by Wheeler 1995) and that the northern form of guanaco (L. g. cacsilensis) is the ancestral form of the domestic llama (Wheeler 1984, 1991). Additional studies suggested that the South Central Andes represent another llama domestication centre (Grosjean et al. 1997; Mengoni Goñalons \& Yacobaccio 2006). On the other hand, extensive hybridization has been documented among domestic SAC species, especially in the alpaca (Stanley et al. 1994; Kadwell et al. 2001), which has created controversy with respect to the phylogenetic origin of this species.

Bolivian SAC specimens have been underrepresented in previous mtDNA studies (Kadwell et al. 2001; Sarno et al. 2004; Marín et al. 2008). It is for this reason as well as the increasing economic importance of SAC populations in Bolivian society that we undertook the present study. The objectives of this work were (i) to assess the mtDNA diversity of Bolivian populations of llamas, alpacas and vicunas from a wide range of the geographical area of distribution of these species and (ii) to shed light on the evolutionary relationships between the sampled Bolivian camelids and other populations of SACs. With these objectives in mind, we performed sequence analysis of the partial sequence of the mitochondrial control region (D-loop) and the entire mitochondrially encoded cytochrome $b($ MT-CYB) gene in a large population of Bolivian llamas as well as in Bolivian alpacas and vicunas. We also included southern Chilean guanacos in our sequencing study. The results presented here represent the first report on the population structure and mtDNA diversity of Bolivian camelids with a particular focus on llamas because of the large size of the available sampling population. Through additional phylogenetic analyses, this work also offers useful information on the complex and dynamic domestication process associated with SAC populations.

\section{Materials and methods}

\section{Sample collection and DNA isolation}

Hair and blood samples were collected from 109 llamas from a wide geographical range on the Bolivian Andean plateau (including the 'kara' and 'thampulli' varieties) corresponding to 13 different locations (Table S1). Blood samples were also obtained from 36 alpacas (including the 'suri' and 'huacaya' fleece types) in the northern and central regions of Bolivia, where the highest concentration of alpacas are found. In addition, ear tissue was obtained from 29 vicunas found in the Apolobamba Natural Area of Integrated Management in northern Bolivia. These samples were taken during experimental captures for collecting wool. Finally, blood samples were obtained from a total of 30 guanacos from the INIA Experimental Station-Kampenaike, Punta Arenas, Chile. Based on their geographical location and morphological features, the vicuna samples correspond to the northern form of the species ( $V . v$. mensalis), and the Chilean Patagonian guanacos correspond to the southernmost form of the species (L. g. guanicoe). Total genomic DNA isolation from hair samples was performed using a modified protocol based on the method described by Woodward et al. (1994). The protocol used for DNA extraction from blood samples was adapted from the method described by Doyle \& Doyle (1987). DNA from ear tissue samples was extracted using the DNeasy Tissue kit (Qiagen) following the manufacturer's instructions.

\section{Sequencing analysis}

The complete MT-CYB gene (1140 bp) and part of the D-loop region ( $513 \mathrm{bp}$ ) were amplified by PCR using the primer pairs detailed in Table S2, following the method described by Marin et al. (2007b). The amplified fragments were purified by incubation with $4 \mathrm{U}$ of ExoSAPIT (Amersham Biosciences, GE Healthcare) at $37^{\circ} \mathrm{C}$ for $30 \mathrm{~min}$, followed by an enzyme deactivation phase for $15 \mathrm{~min}$ at $80^{\circ} \mathrm{C}$. Dideoxy sequencing in both directions was performed with the BIGDYe terminator version 3.1 Cycle Sequencing Kit (Applied Biosystems) using the same primers used for fragment amplification. Additional internal primers, which are also shown in Table S2, were designed for the MT-CYB 
gene and the D-loop region based on available reference sequences for guanaco (L. guanicoe; GenBank accessions AY535173 and AY856157 respectively).

\section{Data analysis}

The complete sequence of the MT-CYB gene (1140 bp) was obtained from a total of 178 samples, and the partial sequence of the D-loop region (513 bp) was isolated from 197 individuals. The number of samples analysed per species is provided in Table $\mathrm{S} 1$. For each mtDNA region, the sequences were aligned and compared with published sequences using SEQSCAPE version 2.5 software (Applied Biosystems). The sequence of one guanaco was used as a reference for the analysis of the MT-CYB region (AY535256), whereas the sequence of one llama served as a reference in the analysis of the D-loop region (AP003426). Sequences were aligned using DNA ALIGNMENT software version 1.3.1.1 (Fluxus technology, http://www.fluxus-engineering. com/). The number of polymorphic sites $(S)$, the average number of differences between pairs of sequences $(P)$, haplotype diversity $(h)$ and nucleotide diversity $(\pi)$ were estimated with DNASP version 4.0 (Rozas 2009).

To perform a phylogenetic analysis, in addition to the sequences generated herein, we retrieved 30 additional MTCYB sequences from GenBank belonging to 23 guanacos, 2 vicunas, 3 llamas and 2 alpacas (AY535249-AY535284). A total of 206 GenBank D-loop sequences for 113 guanacos, 72 vicunas, 9 llamas and 12 alpacas were used in the comparison of the D-loop sequences (AY856136AY856341). These GenBank MT-CYB and D-loop sequences included sequences for both the northern (L. g. cacsilensis) and southern guanaco forms (L. g. huanacus, L.g.guanicoe and L.g. voglii). Note that the eight L. g. voglii guanaco sequences obtained from GenBank originated from Bolivia. In the analysis of vicuna sequences, GenBank MT-CYB and D-loop sequences from northern
(V. v. mensalis) and southern specimens (V.v. vicugna) were considered. Precise information on these GenBank sequences is given in Table S5. Using the complete set of sequences, phylogenetic trees were constructed using the neighbour-joining (NJ), Bayesian (MB) and maximum likelihood (ML) methods with MEGA version 5.0 software (Tamura et al. 2011). In these analyses, only the unique haplotypes identified for each group of sequences (MT-CYB or D-loop) were considered. To display the relationships between the identified unique haplotypes, a median-joining network was generated for each of the two studied regions using NETWORK software (version 4.5.1.6; Bandelt et al. 1999). Genetic differentiation between species, populations, groups and subgroups was determined by analysis of molecular variance (AMOVA; Excoffier et al. 1992). ARLEQUIN version 3.0 software (Excoffier et al. 2005) was used to conduct this analysis.

\section{Results}

\section{Genetic diversity}

From the animals sampled in this work, a total of 178 and 197 sequences were obtained for the MT-CYB and D-loop regions respectively. A total of 161 samples were sequenced for both regions (Table S1). Alignment of the sequences revealed 133 polymorphic sites within the MT-CYB gene and 34 polymorphic sites in the D-loop region. These polymorphic sites were grouped into 43 and 44 different haplotypes, which showed 24 and 3 singleton sites in the MT-CYB and D-loop regions respectively (Tables S3 and S4). The haplotype diversity $(h)$ was similar for the MT-CYB gene and the D-loop region. However, the nucleotide diversity $(\pi)$ was slightly higher for MT-CYB than for the D-loop region (Table 1).

The domestic SAC forms showed greater variation in the two analysed fragments than the wild species studied here

Table 1 Genetic diversity parameters estimated in the MT-CYB and D-loop mtDNA regions across the whole South American camelid population sampled in this work (a) and at the species level (b).

\begin{tabular}{|c|c|c|c|c|c|c|}
\hline Region & $n$ & Variable sites $(S)$ & Haplotypes & Singleton sites & Gene diversity $h \pm S D$ & Nucleotide diversity $\pi \pm$ SD \\
\hline \multicolumn{7}{|c|}{ (a) Global genetic diversity across mtDNA region } \\
\hline$M T-C Y B$ & 178 & 133 & 43 & 24 & $0.945 \pm 0.006$ & $0.03398 \pm 0.00124$ \\
\hline D-loop & 197 & 34 & 44 & 3 & $0.942 \pm 0.006$ & $0.01693 \pm 0.00073$ \\
\hline \multirow{2}{*}{\multicolumn{7}{|c|}{$\begin{array}{l}\text { (b) Per species genetic diversity across region } \\
M T-C Y B\end{array}$}} \\
\hline & & & & & & \\
\hline L. glama & 83 & 119 & 29 & 18 & $0.9410 \pm 0.0110$ & $0.0192 \pm 0.0025$ \\
\hline L. pacos & 36 & 102 & 16 & 7 & $0.9130 \pm 0.0250$ & $0.0363 \pm 0.0016$ \\
\hline V. vicugna & 29 & 9 & 5 & 7 & $0.6720 \pm 0.0590$ & $0.0010 \pm 0.0003$ \\
\hline L. guanicoe & 30 & 34 & 4 & 32 & $0.5790 \pm 0.0470$ & $0.0024 \pm 0.0016$ \\
\hline \multicolumn{7}{|l|}{ D-loop } \\
\hline L. glama & 109 & 30 & 33 & 3 & $0.9380 \pm 0.0090$ & $0.0117 \pm 0.0012$ \\
\hline L. pacos & 33 & 29 & 18 & 3 & $0.9640 \pm 0.0130$ & $0.0201 \pm 0.0015$ \\
\hline V. vicugna & 27 & 2 & 2 & 0 & $0.1420 \pm 0.0860$ & $0.0006 \pm 0.0003$ \\
\hline L. guanicoe & 28 & 7 & 4 & 5 & $0.5630 \pm 0.0630$ & $0.0020 \pm 0.0001$ \\
\hline
\end{tabular}

$n$, number of samples. 
Table 2 Pairwise genetic distances between the four South American camelid species according to analysis of the MT-CYB and D-loop mtDNA regions.

\begin{tabular}{|c|c|c|c|c|}
\hline Population & $M T-C Y B(n)$ & Population pairwise Fst & D-loop $(n)$ & Population pairwise $F_{\mathrm{st}}$ \\
\hline L. glama vs. L. pacos & 119 & 0.172 & 142 & 0.091 \\
\hline L. guanicoe vs. L. pacos & 66 & 0.502 & 61 & 0.317 \\
\hline L. guanicoe vs. L. glama & 113 & 0.501 & 137 & 0.295 \\
\hline V. vicugna vs. L. pacos & 65 & 0.497 & 60 & 0.538 \\
\hline V. vicugna vs. L. glama & 112 & 0.765 & 136 & 0.709 \\
\hline V. vicugna vs. L. guanicoe & 59 & 0.974 & 55 & 0.954 \\
\hline
\end{tabular}

(Table 1). On a species level, according to all diversity parameters, the vicuna showed the lowest genetic variability, followed by the guanaco, the alpaca and the llama. This trend was true for all parameters used to assess both mtDNA regions, with the exception of $h$ estimated for the D-loop region and $\pi$ calculated for both sequences. For these parameters, the alpaca presented the highest estimates of diversity (Table 1). The alignment of the polymorphic sites identified in the MT-CYB and D-loop regions of the samples sequenced here is shown in Tables S3 and S4 respectively.

\section{Species differentiation}

The total genetic variation of the MT-CYB gene estimated by AMOVA revealed significant genetic differentiation when the populations were grouped by species $(P<0.001)$. The genetic differentiation values estimated among species and within species for this region were high $\left(F_{s t}=0.594\right.$ and 0.406 respectively). For the D-loop region, slightly lower genetic differentiation was observed among species $\left(F_{s t}=0.498\right)$, whereas the genetic differentiation within species was higher $\left(F_{s t}=0.502\right)$ than the estimates obtained for the MT-CYB gene. For each pair of species, all of the comparisons showed moderate to high levels of genetic differentiation. The greatest pairwise distance was observed between guanacos and vicunas for both regions $\left(F_{s t}=0.974\right.$ for MT-CYB and $F_{s t}=0.954$ for the D-loop). In contrast, the lowest differentiation was observed between llama and alpaca populations $\left(F_{s t}=0.172\right.$ and 0.091 for MT-CYB and the D-loop respectively). The $F_{s t}$ values estimated between each domestic species and its recognized ancestor were intermediate (range: 0.295-0.538; Table 2).

\section{Phylogenetic analyses}

Based on the sequences generated in this work and those obtained from GenBank, the results of the phylogenetic analyses performed for the MT-CYB and D-loop sequences were generally consistent with each other. The tree topologies obtained with the NJ, MB and ML methods for the unique haplotypes identified for the MT-CYB and D-loop sequences were very similar. Thus, only the NJ trees are shown in Figs 1a \& 2a. To assess the interspecies and intraspecies variation for this complete set of sequences, median-joining networks showing the genealogical relationships between the active haplotypes were also constructed for the MT-CYB and D-loop sequences (Figs $1 \mathrm{~b}$ \& $2 \mathrm{~b}$ respectively). The $\mathrm{NJ}$ tree and the median-joining network obtained for both sequences showed similar patterns.

Following phylogenetic analysis of the available 208 MTCYB sequences, a total of 158 polymorphic sites were grouped into 69 unique haplotypes (Table S6). Both the NJ tree and the median-joining network revealed two major haplogroups. The first major haplogroup contained all guanaco $(G)$ sequences, and the second contained all vicuna haplotypes (V; Fig. 1). Separation of these two clades was supported by bootstrap values of $100 \%$. The corresponding median-joining network analysis revealed 96 mutational steps between the $\mathrm{G}$ and $\mathrm{V}$ haplogroups. The domestic species, llama and alpaca, were found in both the $\mathrm{G}$ and $\mathrm{V}$ clades. However, most of the individuals (82\%), including $91 \%$ of the llamas and $63 \%$ of the alpacas, were found within the $\mathrm{G}$ clade. In clade $\mathrm{G}$, two different haplogroups, G1 and G2, could be differentiated. A total of 29 mutational steps were identified between these two haplogroups (Fig. 1). The G1 haplogroup contained 27 unique haplotypes from a total of 78 individuals. These individuals included several llamas (58/86) and alpacas (17/38) and three guanacos of different subspecies (L. g. guanicoe, L. g. huanacus and L. g. cacsilensis). In the G2 haplogroup, a total of 31 unique haplotypes were identified from 77 animals. These animals consisted of 29 southern Chilean guanacos sequenced here (L.g.guanicoe) and another 21 GenBank southern guanacos (L. g. huanacus and L.g.guanicoe). In addition, two L.g. cacsilensis GenBank guanacos and a number of llamas (20/86) and alpacas (7/38) were included in G2. The four most frequent haplotypes identified in G1 were shared between llamas and guanacos or between llamas and alpacas. Twenty-two of the 31 haplotypes identified in group G2 were exclusively associated with guanacos, including the two most frequent haplotypes in this group. The same sharing pattern was observed in G1 for the haplotypes shared between species (see Table S6 for more details). In each of both the G1 and G2, we found one haplotype shared between Bolivian llamas and southern Chilean guanacos (L. g. guanicoe), whereas no shared haplotypes were found between llamas 


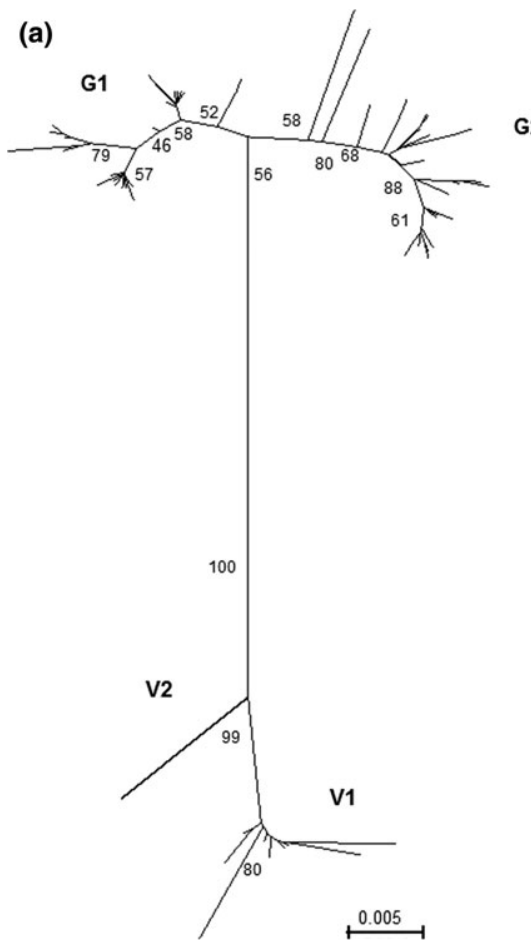

(b)

G2

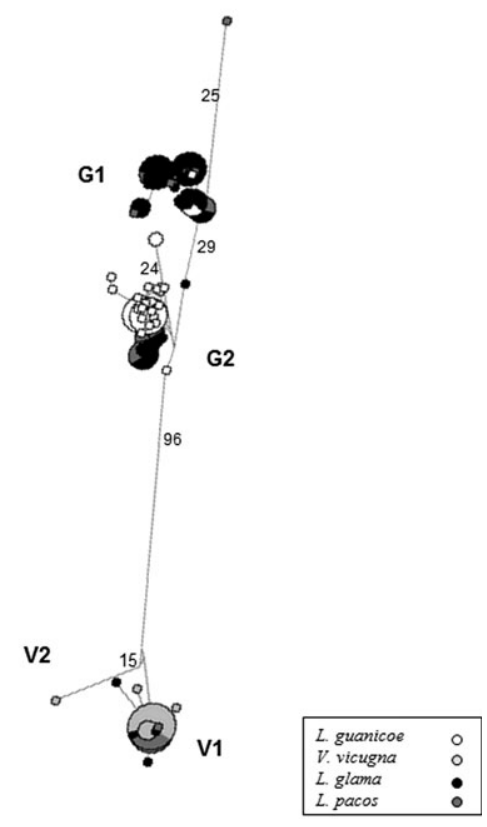

Figure 1 (a) Neighbour-joining tree constructed based on the 69 unique haplotypes established using the 208 MT-CYB sequences (1140 bp) analysed herein. This tree was obtained using the NJ method. The scale represents the genetic distance. Bootstrap values are indicated on cluster nodes. (b) Median-joining network of the South American camelid haplotypes for the MT-CYB gene. The circle area is approximately proportional to the frequency.

(a)

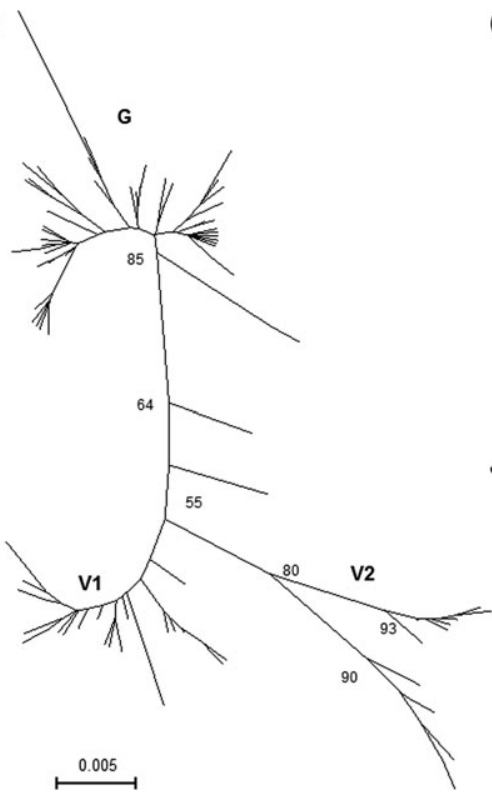

(b)

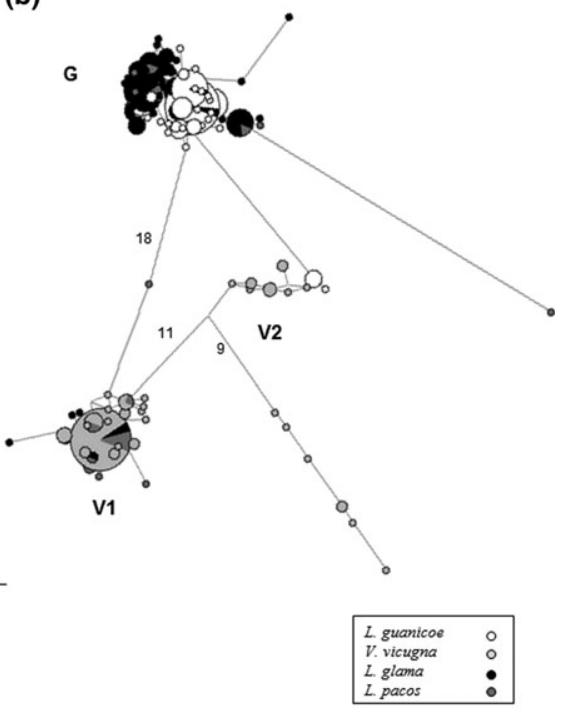

Figure 2 (a) Neighbour-joining tree constructed based on the 101 unique haplotypes established using the 403 D-loop sequences (513 bp) analysed herein. This tree was obtained with the NJ method. The scale represents the genetic distance. Bootstrap values are indicated on cluster nodes. (b) Median-joining network of the South American camelid haplotypes for the D-loop region. The circle area is approximately proportional to the frequency.

and northern Peruvian guanacos (L.g. cacsilensis). All vicunas were found in clade $\mathrm{V}$, together with some alpacas and llamas. The MT-CYB NJ tree and the median-joining network indicated two distinct haplogroups within this clade, V1 and V2, which were supported by a $99 \%$ bootstrap value and 15 mutational steps detected between 
them. All northern vicunas (V.v. mensalis; 30/30) and some llamas (8/86) and alpacas (14/38) were grouped together $(\mathrm{V} 1)$. However, the single southern vicuna $(V . v$. vicugna) included in this analysis branched away from that group (V2). Ten haplotypes were established in haplogroup $\mathrm{V} 1$, and the two major haplotypes shared by vicunas and the two domestic species were found in approximately $79 \%$ of the animals belonging to this haplogroup.

After studying the 406 D-loop sequences available for phylogenetic analysis, a total of 61 polymorphic sites were identified and grouped into 101 unique haplotypes (Table S7). The NJ tree also showed two main clades, G and $\mathrm{V}$, with a supporting bootstrap value of $64 \%$, whereas two isolated branches were found at intermediate distance from the two main clades. In this case, the median-joining network analysis revealed 18 mutational steps establishing the separation between haplogroups $G$ and V. The distribution of the domestic species between these two main clades was similar to the distribution observed based on the MT-CYB haplotypes. Most of the llamas and alpacas were found within the $\mathrm{G}$ clade ( $81 \%$ of the domestic specimens). In this case, distinct subgroups could not be clearly defined within clade $\mathrm{G}$ (Fig. 2a). All of the southern guanaco sequences considered (L.g.guanicoe, L.g.huanacus and L. g. voglii), which included most of the Chilean guanacos sequenced here and the Bolivian, Chilean and Argentinean guanaco sequences retrieved from GenBank, were localized to the right branches of clade G. The only exception consisted of three Chilean guanaco sequences that were found on the left branches (L. g. guanicoe and L. g. huanacus). Northern guanacos (L. g. cacsilensis) were found on both branches (9/16 and 7/16 on the right and left branches respectively). The left branches also included most of the Bolivian llamas (97/109), with only two of them being found on the right branches. Clade $G$ also contained $31 / 53$ of the Bolivian alpacas, which were mainly found on the left branches (Fig. 2a). According to the median-joining network, 27 of the 101 haplotypes included in clade G were exclusively guanacos. However, the most frequent haplotype was also found in llamas. Bolivian llamas shared two haplotypes with northern Peruvian guanacos on the left branch and two other haplotypes with southern guanaco forms from Chile, Argentina and Bolivia, on both left and right branches. Three of the clade G haplotypes (left branches) were shared among guanacos, llamas and alpacas (Fig. 2b; Table S7). Analysis of the D-loop sequences clearly showed two distinct subgroups within clade $\mathrm{V}$, with an estimated bootstrap value of $80 \%$ and 11 mutational steps detected between subclades V1 and V2 (Fig. 2). Haplogroup V1 included all of the Bolivian vicunas analysed (V.v. mensalis; 27/27), whereas most of the southern vicuna sequences obtained from GenBank ( $V$. v. vicugna; 17/19) were identified as belonging to haplogroup V2. All of the domestic specimens in clade $\mathrm{V}$ were found within $\mathrm{V} 1$ (10 llamas and 21 alpacas). Two of the V1 haplotypes were shared by vicunas, alpacas and llamas (see Table S7 for more details).

The NJ tree obtained for the D-loop sequences showed evidence of two new matrilineal lineages that were distinct from the previously reported $\mathrm{G}$ and $\mathrm{V}$ clades. This conclusion is based on the two branches observed at intermediate distance from the two main clades (Fig. 2a). The first of these haplotypes, which is closer to the $\mathrm{G}$ clade and was designated H46, included only one alpaca. The divergence between this unique haplotype and clade $\mathrm{G}$ was supported by a bootstrap value of $85 \%$. The second of these haplotypes, which is closer to the $\mathrm{V}$ clade and was designated H101, was found only in one llama. In this case, the bootstrap value distinguishing between this haplotype and clade $\mathrm{V}$ was $55 \%$. In the corresponding median-joining network, only the H46 alpaca haplotype was found to represent an intermediate haplogroup between the $\mathrm{G}$ and $\mathrm{V}$ major haplogroups (with 9 mutational steps between the $\mathrm{G}$ core haplotype and the $\mathrm{V}$ core haplotype). The llama H101 haplotype was located in the V1 haplogroup and presented the largest number of mutational steps identified within this subgroup (five from the core V1 haplotype).

The median-joining networks obtained for both mtDNA regions showed prevalent and widespread haplotypes for guanacos and vicunas. The prevalence of these haplotypes might suggest rapid demographic expansions for these species in the geographical regions studied.

\section{Discussion}

\section{Genetic diversity and population structure}

Our analyses of mtDNA sequences obtained from the SAC population sampled in this study showed appreciable genetic variability. The slightly higher diversity observed for the MT-CYB gene than for the D-loop region in guanaco, llama and vicuna is surprising. Across different mammalian genera, the D-loop region is considered to be a hypervariable region (Pedrosa et al. 2007; Alter \& Palumbi 2009). Our results are supported by data reported on guanacos by Marín et al. (2008). It is possible that this observation is linked to adaptive evolution owing to living in high altitudes, although this hypothesis needs to be confirmed. Supporting this hypothesis, the alpaca, which shows the most restricted longitudinal and altitudinal distribution, showed the opposite pattern to the other studied camelids (higher variability observed in the D-loop than in MT-CYB). A previous study showed rapid evolution of the cytochrome $c$ oxidase subunit II in camelids compared with other cetartiodactyls, which could suggest a possible relationship with the adaptation of New-World camelids to the Andean area conditions (Di Rocco et al. 2006).

The higher levels of genetic variability observed among the domestic species compared with the wild species (Table 1) 
may be explained by severe bottlenecks affecting the wild species following domestication, as they have been exposed to hunting activities without any protection until recently. A severe bottleneck occurred in the vicuna population in the late 1960s, when only approximately 2000 specimens remained in all of Argentina, Bolivia and Chile (Pauquet 2005). Similarly, in the early 1970s, the population of guanacos on the Chilean side of Tierra del Fuego consisted of approximately 4500 animals (Sarno et al. 2001). These bottlenecks may explain the low genetic diversity previously reported for northern Bolivian vicuna populations when compared with southern Bolivian and Chilean populations (Sarno et al. 2004) and the low to medium genetic diversity reported here for the isolated southern guanacos sampled from Chilean Patagonia (L. g. guanicoe). Other authors have previously reported a low genetic diversity for the large southern guanaco populations (L.g.guanicoe) when compared with the small, fragmented populations from northern Chile and Peru (L. g. cacscilensis; Schmitt \& Hewitt 2004; Marín et al. 2008). The higher variability reported by Marin et al. (2007a) in the D-loop region for northern vicunas (V.v. mensalis) compared with the variability described here for specimens from the same region may be explained by the larger size and different origin (Chile and Peru) of the population analysed by these authors. Future research projects assessing the variability in Bolivian guanaco and vicuna populations should involve large sample populations covering most of the geographical range of this species in this country. This kind of research could aid in the implementation of suitable management and conservation programmes for these species, helping to insure appropriate levels of genetic variability and avoiding inbreeding depression.

This work represents the first detailed study of the genetic diversity in mtDNA in South American llamas. Therefore, direct comparison with previous studies is not possible. The high levels of genetic diversity identified in the llama populations studied here agree with a previous analysis of 13 Peruvian llamas (Stanley et al. 1994). Additionally, similar levels of genetic diversity were observed between the small group of alpacas and the large and diverse group of llamas studied here, suggesting important levels of hybridization in these domestic populations.

Analysis of molecular variance suggested a high level of population structuring in the SAC populations analysed in this work. The short pairwise distances identified between llamas and alpacas, which were shorter than the distances estimated between the vicuna-alpaca and guanaco-llama pairs, also support the existence of a high level of hybridization between the studied domesticated populations.

\section{Phylogenetic relationships}

Based on previous mtDNA studies, vicunas and guanacos have been suggested as monophyletic clades, G and V, which are supported by the high bootstrap values (> 90\%) estimated from analyses of the MT-CYB (Stanley et al. 1994; Kadwell et al. 2001; Marin et al. 2007b) and D-loop (Marin et al. 2007b) sequences. This hypothesis is also supported by the phylogenetic analysis performed in the present study for both mtDNA regions, which showed two distinct clades for wild vicunas (V) and guanacos (G). The intermediate haplotypes identified between $\mathrm{G}$ and $\mathrm{V}$ in our NJ D-loop tree may explain the moderate bootstrap value observed between the major clades G and V (64\%). Interestingly, these intermediate branches suggest the existence of two putative new matrilineal lineages, which are represented by the two haplotypes of alpaca and llama identified in the middle of the tree. The nucleotide diversity separating the unique alpaca haplotype $\mathrm{H} 46$ from clades $\mathrm{G}$ and $\mathrm{V}$ was measured ( $K=5.677 \%$ and $9.376 \%$ respectively). These comparisons were also made for the unique llama haplotype $\mathrm{H} 101$ ( $K=5.570 \%$ and $9.288 \%$ respectively). Although the observed values are lower than those detected between clades $\mathrm{G}$ and $\mathrm{V}(K=10 \%)$ and considering that these levels of genetic differentiation are preliminary, these comparisons support the conclusion that haplotypes H1O1 and H46 are sufficiently divergent to represent putative new maternal clades in the SAC phylogenetic tree distinct from those previously described. Similar reports of increasing complexity have been described related to the domestication of other mammals, such as pigs (Larson et al. 2005), goats (Joshi et al. 2004), sheep (Meadows et al. 2007) and cattle (Murray et al. 2010). In these cases, it seems that as more regions are sampled, more lineages are found, which could also happen in relation to SAC populations.

The significant sequence divergence observed within clade G based on our analysis of MT-CYB sequences and suggested by our analysis of the D-loop region supports the existence of two previously described guanaco lineages: a northern group representing L. g. cacsilensis populations and another major clade comprising the southern forms L. g. huanacus, L. g. guanicoe and L. g. voglii (González et al. 2006; Marín et al. 2008). Supporting the initial hypothesis that suggests that llamas originated from L. g. cacsilensis (Wheeler 1984, 1991; Palma et al. 2001), we found two llama haplotypes shared with this guanaco subspecies from northern Chilean and Peru in the D-loop sequences. However, we have also identified Bolivian llama haplotypes shared with southern guanaco forms from Bolivia, Argentina and Chile (L. g. voglii, L. g. huanacus and L. g. guanicoe). These observations deviate from the previously proposed hypothesis that the domestic llama originated from northern guanaco populations (L.g. cacsilensis) in the Central Peruvian Andes (Wheeler 1995; Palma et al. 2001).

Looking in detail, these llamas were from Nor Cinti and Nor Lípez, which are populations from the south-west of Bolivia. Hence, the results of the present study, which represents the first mtDNA survey involving sequences from a large sample of Bolivian llamas and guanacos from both 
northern and southern populations, may help to draw a more complete picture of the domestication events relating these two species than that which is currently accepted. Hence, some Bolivian llama populations could have been domesticated from a different matrilineal population than initially suggested. According to our results, the matrilineal population would involve southern guanaco forms or, alternatively, a now extinct wild ancestor. The existence of multiple domestication centres (N. Peru, S. Peru, N. Chile, Bolivian and N. W. Argentina) leading to the modern populations of domestic SACs has been suggested based on archaeozoological evidence (Yacobaccio 2004; Gallardo \& Yacobaccio, 2007; Mengoni Goñalons 2008). Northern Chile has previously been suggested as one of these potential domestication centres based on the analysis of D-loop sequences (Marin et al. 2007b). The present study would support, also at the genetic level and taking into account the archaeological evidence, the existence of additional llama domestication centres in Argentina and Bolivia. This may serve to increase our understanding of the complex and dynamic process of SAC domestication and to move current models of domestication from a regional to a super-regional or pan-Andean scale, as previously suggested by Mengoni Goñalons (2008). Taking into account the lack of archaeological evidence supporting the domestication of the Patagonian guanaco (Benavente et al., 1985), the overland migration of L. guanicoe towards the most austral regions of South America is the more likely hypothesis to explain the haplotypes that were shared between Bolivian llama and southern Chilean guanacos. In addition, we may conclude that Bolivian llama populations possess an invaluable gene pool and share ancestral haplotypes with guanacos currently distributed in countries such as Argentina, Chile, Bolivia and Peru.

The accepted subdivision for northern (V.v. mensalis) and southern (V. v. vicugna) vicunas (Sarno et al. 2004; Marin et al. 2007a) is supported by our results, with all of the Bolivian vicunas grouping together in clade V1 (Figs 1a \& 2a). As the median-joining network analyses suggested a demographic expansion for this species and guanacos, we performed a Tajima's D-test (Tajima, 1989) and a Fu's F-test $(\mathrm{Fu}, 1997)$ on the data from the four species under examination. The results of these analyses identified some evidence of demographic expansion for the vicunas, although this finding did not achieve statistical significance (data not shown).

The high level of hybridization previously suggested for the domestic species based on the genetic diversity analyses described above was also supported by the phylogenetic analyses. Although our results clearly support a model in which the guanaco is the ancestor of the llama, we found some llamas in the V clade (9\% for MT-CYB and $8 \%$ for the D-loop). Based on sequences from both mtDNA regions, we identified haplotypes shared by llama, vicunas and alpacas, which suggests that there has been an introgression of $\mathrm{V}$
mtDNA some time in the past into Bolivian llama populations.

The origin of the alpaca appears to be more complex than in the case of the llama. Whereas the existence of haplotypes exclusively shared between vicunas and alpacas clearly indicates that the vicuna is the ancestor of the alpaca, we found a considerable number of alpacas in the $\mathrm{G}$ clade based on both mtDNA regions (63\% for MT-CYB and $51 \%$ for the D-loop). Shared haplotypes among guanacos, llamas and alpacas were identified only in the analysis of D-loop sequences. The large number of alpacas in the $G$ clade detected here indicates a very high level of hybridization in Bolivian alpacas, which agrees with observations reported by Stanley et al. (1994) and Kadwell et al. (2001) in other alpaca populations. In contrast, Marin et al. (2007b) reported only 6\% of alpacas within the G clade based on the analysis of samples from Peruvian and Chilean alpacas. Based on our mtDNA analyses, the origin of the alpaca remains uncertain. The two possible hypotheses for this origin, suggesting either a mixed origin for this species or a high level of hybridization occurring some time in the past, either during or after domestication, are plausible, as previously formulated by other authors (Stanley et al. 1994; Kadwell et al. 2001). Higher levels of hybridization in alpacas than in llamas might suggest that this hybridization is the result of controlled crosses during or after the domestication of alpacas, with a preference for crosses between $\mathrm{V}$ males and G females. Analysis of other genetic markers, especially chromosome Y markers, could help to draw a more complete picture of the domestication events that led to the current Bolivian alpaca and llama populations.

The results of our D-loop analysis indicated that all the $\mathrm{G}$ haplotypes shared between guanacos and alpacas also exist in llamas. This commonality could indicate that crosses between the domestic forms are more frequent, as suggested by other authors (Kadwell et al. 2001; Marin et al. 2007b). However, based on investigation into behavioural patterns, Hemmer (1990) suggested that the alpaca is a mixture of both lines and was produced by crossbreeding captured vicunas with the only available domestic animal at the time, the llama. The fact that vicunas may have been more difficult to domesticate than guanacos because of their behaviour (González 2002) supports this model. Hence, crosses with llamas could have been used to increase the docility of this species during domestication.

Traditional Andean herders of these domestic species recognize the existence of llama and alpaca crosses (Kadwell et al. 2001; Marin et al. 2007b). In Peru in particular, crosses between male alpacas and female llamas, which are commonly known as 'huarizos', have been used to increase the population of animals that produce the higher-priced alpaca fibre. Crosses between male llamas and female alpacas, which are known as 'misti', have been used to 
obtain greater fleece weights and increase income (Kadwell et al. 2001), as the carcass yield of crossbred animals is approximately $29 \%$ higher than that of pure alpacas (TamuReyna 2005). In Bolivia, we observe some mixed populations consisting of llamas, comprising the majority, and alpacas, especially in the northern highlands (such as in Pacajes, Sajama, and Turco).

It is important to attempt to reconcile the much lower levels of hybridization observed in the Peruvian alpaca populations analysed by Marin et al. (2007b) with results from other studies (Stanley et al. 1994; Kadwell et al. 2001; the present study). The levels of hybridization may be influenced by the geographical distribution of the species involved in the hybridization events. In Bolivia, where a large number of llamas are present, high levels of hybridization are found when compared with Chilean and Peruvian alpacas (Marin et al. 2007b). However, in the Bolivian alpacas from different regions analysed here, we found a pattern of hybridization that was not directly related to the density of the llamas in the different regions; the alpacas from northern Bolivia, where there are fewer llamas, showed hybridization levels similar to that of the alpacas from central and south Bolivia, where alpacas are scarcely present owing to the lack of humidity. Hence, further studies should be designed to definitively confirm or reject this hypothesis.

By providing information regarding autochthonous specimens in Bolivia, this work contributes to our knowledge regarding the diversity of SAC populations. The results of our phylogenetic analyses also provide an opportunity to revisit the relationship between domestic SACs and the current wild forms and increase our understanding of the complex and dynamic process of SAC domestication. Understanding this relationship may yield a better understanding of the evolutionary origins of SAC populations. In addition, the information reported here may contribute to the development of conservation plans for wild species as well as genetic improvement practices in llamas and alpacas.

\section{Acknowledgements}

We gratefully acknowledge the financial support received from the AECID by projects A/010497/07 y A/017114/08. Julia Barreta's scholarship is provided by an MAE-AECID fellowship (Spanish Agency for International Development Cooperation; Spanish Ministry of Foreign Affairs and Cooperation). Financial support from the Swedish Cooperation Agency (SIDA) to UMSA is also acknowledged, as well as logistical support from the Institute of Aymara Language and Culture (ILCA). Finally, we acknowledge the support of the people who generously helped with discussion or by providing information and samples for this study in Bolivia: Denise Arnold, Ramiro Colque, Carlos Coello, Manuel Ruiz, Luis Iñiguez and Tito Rodriguez.

\section{References}

Alter E. \& Palumbi S. (2009) Comparing evolutionary patterns and variability in the mitochondrial control region and cythocrome $b$ in three species of Baleen Whales. Journal of Molecular Evolution 68, 97-111.

Bandelt H.-J., Forster P. \& Röhl A. (1999) Median-joining networks for inferring intraspecific phylogenies. Molecular Biology and Evolution 16, 37-48.

Benavente A. (1985) Reflexiones en torno al proceso de domesticación de camélidos en los valles del Centro y Sur de Chile. Boletín del Museo Regional de la Araucanía 2, 37-52.

Cuéllar E., Jammes L., Castro G. \& Segundo J. (2002) Current status of the Guanaco Lama guanicoe voglii in the Bolivian Chaco. Technical Report 69. Proyecto Kaa-Iya, Santa Cruz, Bolivia

Di Rocco F., Parisi G., Zambelli A. \& Vida-Rioja L. (2006) Rapid evolution of cytochrome c oxidase subunit II in camelids (Tylopoda, Camelidae). Journal of Bioenergetics and Biomembranes 38, 293-8.

Doyle J.J. \& Doyle J.L. (1987) A rapid DNA isolation procedure for small quantities of fresh leaf tissue. Phytochemical Bulletin 19, 11-5.

Excoffier L., Smouse P.E. \& Quattro J.M. (1992) Analysis of molecular variance inferred from metric distances among DNA haplotypes: application to human mitochondrial DNA restriction data. Genetics 131, 479-91.

Excoffier L., Laval G. \& Schneider S. (2005) ARLEOUIN ver.3.0: an integrated software package for population genetics data analysis. Evolutionary Bioinformatics Online 1, 47-50.

FAO (2005) Situación actual de los camélidos sudamericanos en Bolivia. http://www.cites.org/eng/cop/14/prop/E14-P08.pdf.

Fu Y.X. (1997) Statistical tests of neutrality of mutations against population growth, hitchhiking and background selection. Genetics 147, 915-25.

Gallardo F. \& Yacobaccio H. (2005) Wild or domesticated? camelids in early formative rock art of the Atacama Desert (Northern Chile) Latin American Antiquity 16, 115-30.

González J. (2002) Etología de camélidos y arte rupestre de la subregión Río Salado (norte de Chile, II Región). Estudios Atacameños 23, 23-32.

González B.A., Palma R., Zapata B. \& Marín J.C. (2006) Taxonomic and biogeographical status of guanaco Lama guanicoe (Artiodactyla, Camelidae). Mammal Review 36, 157-78.

Grosjean M., Núñez L., Cartajena I. \& Messerli B. (1997) MidHolocene climate and culture change in the Atacama desert, northern Chile. Quaternary Research 48, 239-46.

Hemmer H. (1990) Domestication: The Decline of Environmental Appreciation, 2nd edn, pp. 217. Cambridge University Press, Cambridge, UK.

Joshi M., Rout P., Mandal A., Tyler-Smith C., Singh L. \& Thangaraj K. (2004) Phylogeography and origin of Indian domestic goats. Molecular Biology and Evolution 21, 454-62.

Kadwell M., Fernández M., Stanley H.F., Baldi R., Wheeler J.C. \& Rosadio R. (2001) Genetic analysis reveals the wild ancestors of the llama and alpaca. Proceedings of the Royal Society 268, 2575-84.

Larson G., Dobney K., Albarella U. et al. (2005) Worldwide phylogeography of wild boar reveals multiple centres of pig domestication. Science 307, 1618-21.

MACA (2003) Ministerio de Agricultura Ganadería y Desarrollo Rural. La Paz, Bolivia. 
Marin J.C., Casey C.S., Kadwell M. et al. (2007a) Mitochondrial phylogeography and demographic history of the vicuña: implications for conservation. Heredity 99, 70-80.

Marin J.C., Zapata B., González B.A. et al. (2007b) Sistemática, taxonomía y domesticación de alpacas y llamas: nueva evidencia cromosómica y molecular. Revista Chilena de Historia Natural 80, $121-40$.

Marín J.C., Spotorno A.E., González B.A., Bonacic C., Wheeler J.C., Casey C.S., Bruford M.W., Palma R.E. \& Poulin E. (2008) Mitochondrial DNA variation and systematics of the guanaco (Lama guanicoe, Artiodactyla: Camelidae). Journal of Mammalogy 89, 269-81.

Meadows J., Cemal I., Karaca O., Gootwine E. \& Kijas J. (2007) Five ovine mitochondrial lineages identified from sheep breeds of the near east. Genetics 3, 1371-9.

Mengoni Goñalons G.L. (2008) Camelids in ancient Andean societies: a review of the zooarchaeological evidence. Quaternary International 185, 59-68.

Mengoni Goñalons G.L. \& Yacobaccio H.D. (2006) The domestication of South American camelids: a view from the South-Central Andes. In: Documenting Domestication: New Genetic and Archaeological Paradigms (Ed. by M.A. Zeder), pp. 228-44. University of California Press, Berkeley.

Murray C., Huerta-Sanchez E., Casey F. \& Bradley D.G. (2010) Cattle demographic history modeled from autosomal sequence variation. Philosophical Transactions of the Royal Society B: Biological Sciences 365, 2531-9.

Palma R.E., Marín J.C., Spotorno A.E. \& Galaz J.L. (2001) Phylogenetic relationships among South American subspecies of camelids based on sequences of cytochrome-b mitochondrial genes. In: Progress in South American Camelids Research (Ed. by M. G.A. Raunelli). Publication 105, pp. 44-52. EEAP, Gottingen.

Pauquet S. (2005) Diagnosis of Apolobamba Integrated Management Natural Area. ParksWatch Park Profile Series. http://www. parkswatch.org/parkprofiles/pdf/apna_eng.pdf.

Pedrosa S., Arranz J.J., Brito N., Molina A., San Primitivo F. \& Bayón Y. (2007) Mitochondrial diversity and the origin of Iberian sheep. Genetics Selection Evolution 39, 91-103.

Reyna J. (2005) Alpaca breeding in Peru and Perspectives for the Peru. Alpacas Australia, Alpacas New Zealand, World Alpacas. http:// www.elitealpacabreedingsystems.com/library/AlpacaBreedingPeru.pdf

Rozas J. (2009) DNA sequence polymorphism analysis using DNASP. In: Bioinformatics for DNA Sequence Analysis; Methods (Ed. by D. Posada). Molecular Biology Series, Vol. 537, pp. 337-50. Humana Press, NJ.

Sarno R.J., Franklin W., O’Brien S. \& Johnson W. (2001) Patterns of mtDNA and microsatellite variation in an island and mainland population of guanacos in southern Chile. Animal Conservation 4, 93-101.

Sarno R.J., Villalba L., Bonacic C., González B., Zapata B. \& Mac Donald D.W. (2004) Phylogeography and subspecies assessment of vicuñas in Chile and Bolivia utilizing mtDNA and microsatellite markers: implications for vicuña conservation and management. Conservation Genetics 5, 89-102.

Schmitt T. \& Hewitt G.M. (2004) Molecular biogeography of the arctic-alpine disjunct burnet moth species Zygaena exulans (Zygaenidae, Lepidoptera) in the Pyrenees and Alps. Journal of Biogeography 31, 885-93.
Stanley H.F., Kadwell M. \& Wheeler J.C. (1994) Molecular evolution of the family Camelidae: a mitochondrial DNA study. Proceedings of the Royal Society of London Series B: Biological Sciences 256, 1-6.

Tamura K., Peterson D., Peterson N., Stecher G., Nei M. \& Kumar S. (2011) MEGA5: molecular evolutionary genetics analysis using maximum likelihood, evolutionary distance, and maximum parsimony methods. Molecular Biology and Evolution 28, 2731-9.

Tajima F. (1989) The effect of change in population-size on DNA polymorphism. Genetics 123, 597-601.

Wheeler J. (1984) On the origin and early development of Camelide pastoralism in the Andes. In: Animals and Archaeology (Ed. by J. Clutton-Brock \& C. Grigson). BAR Internationel Series 202. Great Britain.

Wheeler J. 1991. Origen, evolución y estatus actual. In: Avances y Perspectivas del Conocimiento de los Camélidos Sudamericanos (Ed. by S. Fernández-Baca), pp. 11-48. FAO, Santiago de Chile.

Wheeler J.C. (1995) Evolution and present situation of the South American Camelidae. Biological Journal of the Linnean Society 54, 271-95.

Wheeler J.C., Chikhi L. \& Bruford M.W. (2006) Genetic analysis of the origins of domestic South American camelids. The domestication of South American camelids: a view from the SouthCentral Andes. In: Documenting Domestication: New Genetic and Archaeological Paradigms (Ed. by M.A. Zeder), pp. 229-341. University of California Press: Berkeley.

Woodward S.R., King M.J., Chiu N.M., Kuchar M.J. \& Griggs C.W. (1994) Amplification of ancient nuclear DNA from teeth and soft tissues. PCR Methods and Applications 13, 244-7.

Yacobaccio H.D. (2004) Social dimensions of camelid domestication in the southern Andes. Anthropozoologica 39, 237-47.

\section{Supporting information}

Additional supporting information may be found in the online version of this article.

Table S1 For each of the studied SAC species the sampled tissue and geographical origin of the samples analysed for the Cyt-b and D-loop mtDNA regions are indicated.

Table S2 Oligonucleotide sequences used for the amplification and sequencing of the mtDNA regions studied in this work (Cyt-b gene and D-loop).

Table S3 Alignment of the polymorphic sites identified by sequencing 1140 bp of the Cyt-b gene from 178 SAC samples. The number of individuals per species showing the haplotype is indicated for each of the 43 identified haplotypes.

Table S4 Alignment of the polymorphic sites identified by sequencing $513 \mathrm{bp}$ of the mtDNA D-loop region from 197 SAC samples. The number of individuals per species showing the haplotype is indicated for each of the 44 identified haplotypes.

Table S5 Sequences obtained from GenBank and included in the phylogenetic analyses performed in the present study. If available, the country of origin of the corresponding samples is indicated, together with the nominal species and subspecies. 
Table S6 Distribution of the four studied species among the unique haplotypes established for 208 Cyt-b sequences through the NJ tree and median joining network analyses. Table S7 Summary of the distribution of the four studied species among the unique haplotypes established for 406 D-loop sequences through the NJ tree and median joining network analyses.
As a service to our authors and readers, this journal provides supporting information supplied by the authors. Such materials are peer-reviewed and may be re-organized for online delivery, but are not copy-edited or typeset. Technical support issues arising from supporting information (other than missing files) should be addressed to the authors. 
Supplementary Table S1 For each of the studied SAC species the sampled tissue and geographical origin of the samples analysed for the Cyt-b and D-loop mtDNA regions are indicated.

\begin{tabular}{|c|c|c|c|c|c|}
\hline Species & Samples & Localities (Country) & $\begin{array}{l}\text { Samples } \\
\text { analysed } \\
\text { for Cyt-b }\end{array}$ & $\begin{array}{c}\text { Samples } \\
\text { analysed } \\
\text { for D-loop }\end{array}$ & $\begin{array}{c}\text { Samples } \\
\text { in } \\
\text { common }\end{array}$ \\
\hline \multirow{15}{*}{ L. glama } & & & 83 & 109 & 77 \\
\hline & Hair & $\begin{array}{l}\text { Ayopaya, Quillacollo, Arani } \\
\text { (Bolivia) }\end{array}$ & 3 & 7 & 3 \\
\hline & Hair & Bolivar (Bolivia) & 0 & 1 & 0 \\
\hline & Hair, Blood & $\begin{array}{l}\text { Pacajes, San Pedro de Totora, } \\
\text { Nor-Carangas (Bolivia) }\end{array}$ & 6 & 8 & 6 \\
\hline & Hair, Blood & Sajama, Carangas, (Bolivia) & 13 & 19 & 13 \\
\hline & Hair, Blood & Sur Carangas, Orinoca (Bolivia) & 7 & 9 & 7 \\
\hline & Hair, Blood & Avaroa (Bolivia) & 11 & 14 & 10 \\
\hline & Blood & La Rivera (Bolivia) & 5 & 3 & 3 \\
\hline & Hair & Franz Tamayo (Bolivia) & 3 & 8 & 3 \\
\hline & Hair & Ingavi, Yawaroko (Bolivia) & 4 & 7 & 4 \\
\hline & Hair & Sud Lipez (Bolivia) & 11 & 11 & 10 \\
\hline & Blood & Nor Lipez (Bolivia) & 10 & 9 & 9 \\
\hline & Hair & Quijarro, Tomas Frias (Bolivia) & 1 & 3 & 1 \\
\hline & Hair & Nor Cinti, Aviles (Bolivia) & 5 & 6 & 5 \\
\hline & Blood & Banco de Germoplasma (Bolivia) & 4 & 4 & 3 \\
\hline L. pacos & Blood & Ulla Ulla, Sajama (Bolivia) & 36 & 33 & 31 \\
\hline V. vicugna & Tissue & ANMIN-Apolobamba (Bolivia) & 29 & 27 & 25 \\
\hline L. guanicoe & Blood & $\begin{array}{l}\text { Experimental Station-Kampenaike } \\
\text { (Chile) }\end{array}$ & 30 & 28 & 28 \\
\hline TOTAL & & & 178 & 197 & 161 \\
\hline
\end{tabular}


Supplementary Table S2 Oligonuclotide sequences used for the amplification and sequencing of the mtDNA regions studied in this work (Cyt-b gene and D-loop)

\begin{tabular}{lll}
\hline \multicolumn{1}{c}{ Primer ID } & \multicolumn{1}{c}{ Sequence 5'-> 3' } & mtDNA region \\
\hline LGlu ARTIO $^{(1)}$ & 5' TCTAACCACGACTAATGACAT 3' & Cyt-b \\
Hthr ARTIO $^{(1)}$ & 5' TCCTTTTTCGGCTTACAAGACC 3' & Cyt-b \\
Lthr ARTIO $^{(1)}$ & 5' GGTCTTGTAAGCCGAAAAAGGA3' & D-loop \\
HLOOP550G $^{(1)}$ & 5' ATGGACTGAATAGCACCTTATG 3' & D-loop \\
L400 $^{(2)}$ & 5' GGGCTATGTACTCCCATGAGG 3' & Cyt-b \\
LBE-02 $^{(2)}$ & 5' CTCCGTAGATAAAGCCACCC 3' & Cyt-b \\
CytB337 $^{(2)}$ & 5' TTCAAGTTTCTAGGAAGGGCG 3' & Cyt-b \\
Lloop0007G $^{(2)}$ & 5'GTACTAAAAGAAAATATCATGTC3 & D-loop \\
H362 $^{(2)}$ & 5' GGTTTCACGCGGCATGGTGATT 3' & D-loop \\
H15998 $^{(2)}$ & 5' CCAGCTTCAATTGATTTGACTGCG 3' & D-loop \\
Dloop747F $^{(2)}$ & 5' TAAAATCGCCCACACACTTTCC 3' & D-loop \\
\hline
\end{tabular}

(1) Primers used in the PCR fragment amplification and subsequent sequencing reaction

(2) Internal primers used for sequencing 
Supplementary Table S3 Alignment of the polymorphic sites identified by sequencing 1,140 bp of the Cyt-b gene from 178 SAC

samples. The number of individuals per species showing the haplotype is indicated for each of the 43 identified haplotypes.

23459124445555666677891111111122222222223333333333333333344444444444444445555555555566666666666677777777777778888888888888999999999999999991111111111111111111

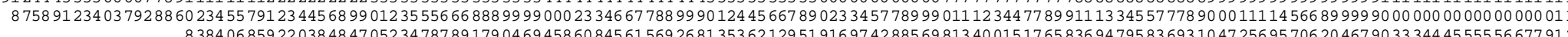
3258148037895815239

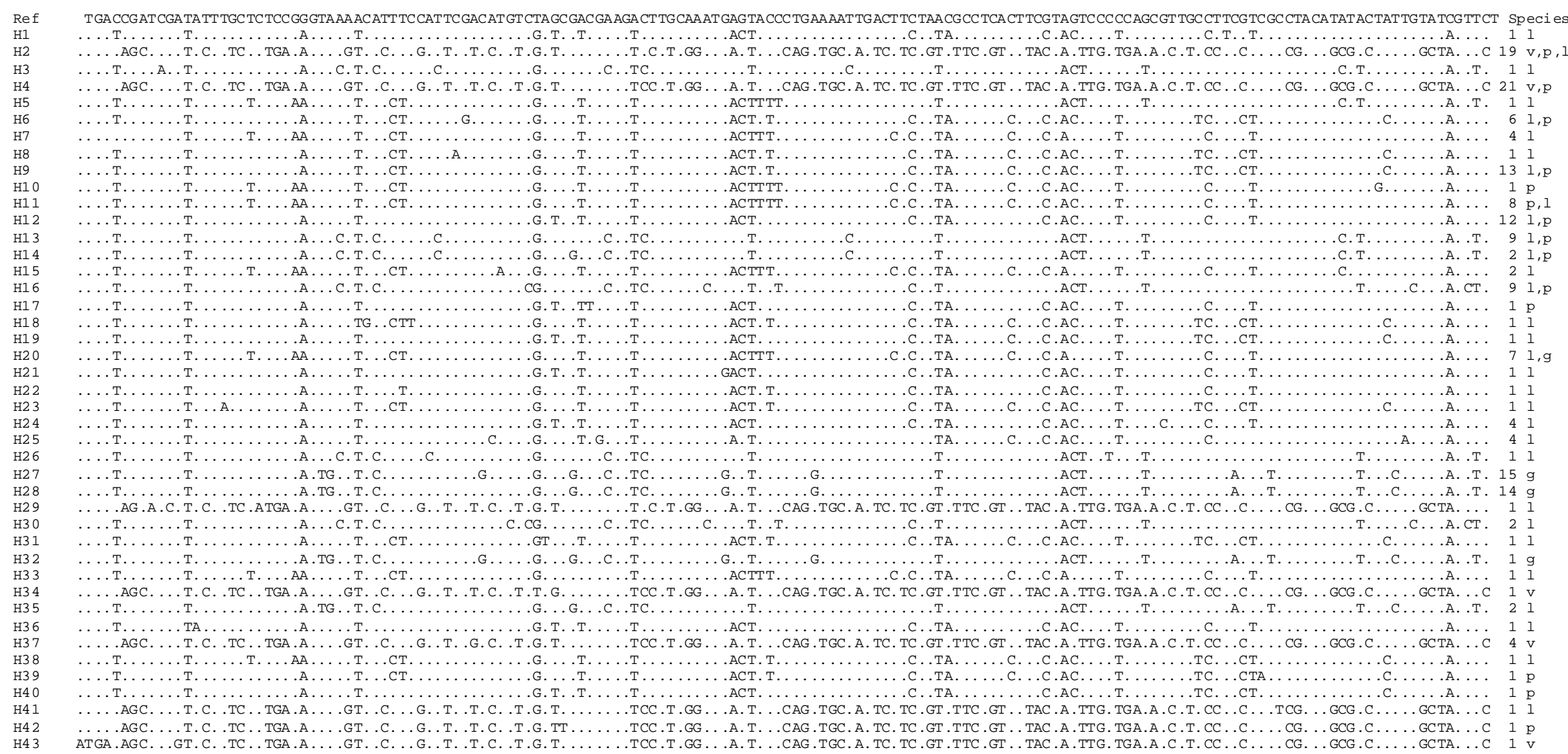

$\mathrm{GG}=$ reference guanaco; $\mathrm{N}=$ number of individuals represented by each haplotype; species: $\mathrm{p}=\mathrm{alpaca}, \mathrm{l}=\mathrm{llama}, \mathrm{v}=$ vicuna, $\mathrm{g}=\mathrm{guanaco}$ 
Supplementary Table S4 Alignment of the polymorphic sites identified by sequencing 513 bp of the mtDNA D-loop region from 197 SAC samples. The number of individuals per species showing the haplotype is indicated for each of the 44 identified haplotypes.

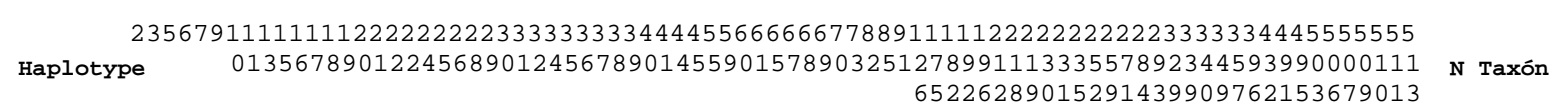

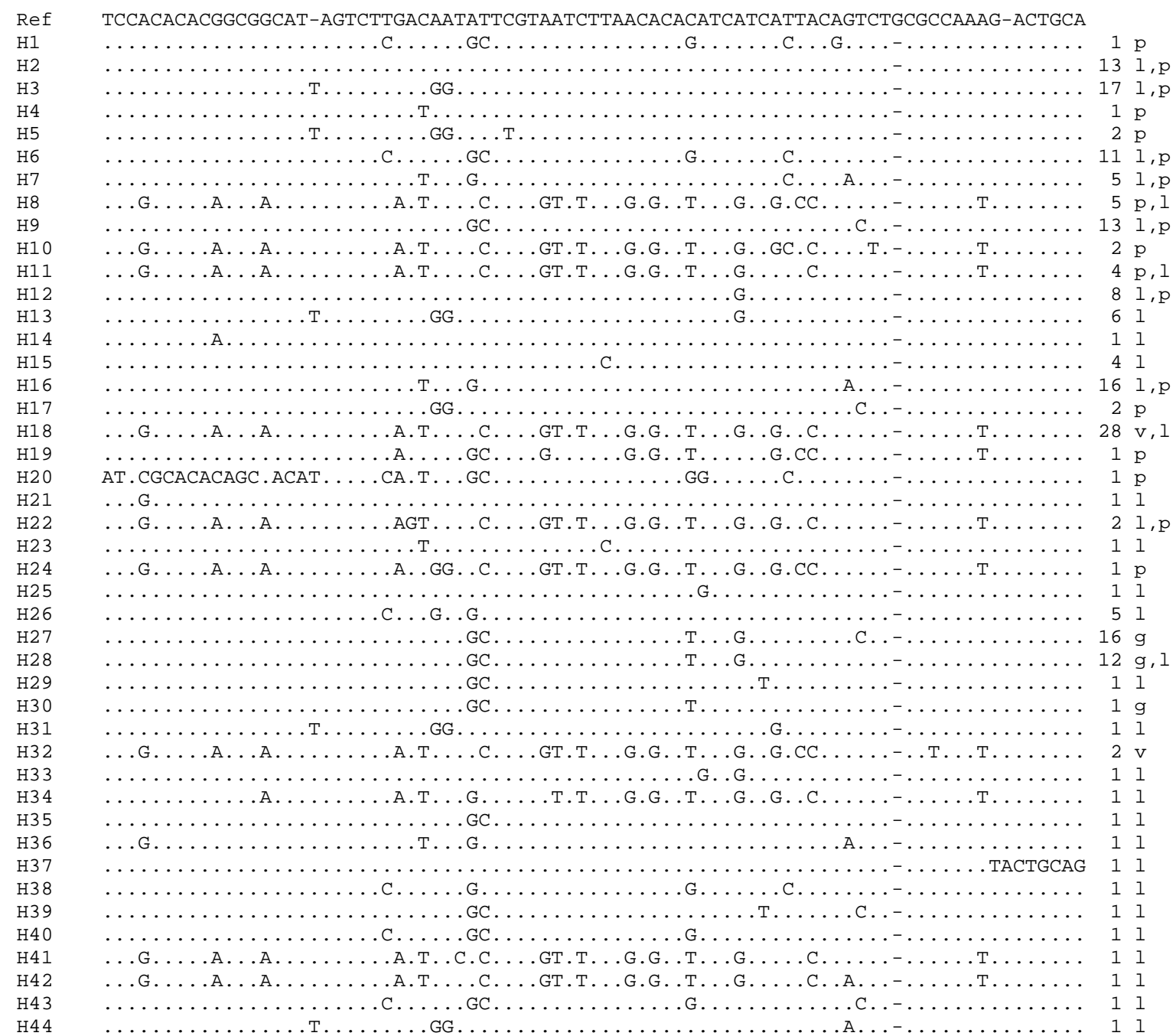

GG= reference llama; $N=$ number of individuals represented by each haplotype; species: $\mathrm{p}=$ alpaca, $\mathrm{l}$ = llama, $\mathrm{v}$ = vicuna, $\mathrm{g}=$ guanaco 
Supplementary Table S5 Sequences obtained from GenBank and included in the phylogenetic analyses performed in the present study. If available, the country of origin of the corresponding samples is indicated, together with the nominal species and subspecies.

\begin{tabular}{|c|c|c|c|c|}
\hline GenBank Acc & Assigned code & Species & Subspecies & $\begin{array}{l}\text { Country of } \\
\text { origin }\end{array}$ \\
\hline \multicolumn{5}{|l|}{ Cyt-b } \\
\hline AY535284 & GGAR08 & Lama guanicoe & L.g. guanicoe & \\
\hline AY535282 & GGAR06 & Lama guanicoe & L.g.guanicoe & \\
\hline AY535281 & GGAR05 & Lama guanicoe & L.g. guanicoe & \\
\hline AY535280 & GGAR04 & Lama guanicoe & L.g. guanicoe & \\
\hline AY535278 & GGAR02 & Lama guanicoe & L.g.guanicoe & \\
\hline AY535277 & GGAR01 & Lama guanicoe & L.g. guanicoe & \\
\hline AY535276 & GGCH18 & Lama guanicoe & L.g. huanacus & \\
\hline AY535274 & GGCH15 & Lama guanicoe & L.g. huanacus & \\
\hline AY535273 & GGCH14 & Lama guanicoe & L.g. huanacus & \\
\hline AY535270 & GGCH12 & Lama guanicoe & L.g. huanacus & \\
\hline AY535269 & GGCH11 & Lama guanicoe & L.g. huanacus & \\
\hline AY535267 & GGCH09 & Lama guanicoe & L.g. huanacus & \\
\hline AY535266 & GGCH08 & Lama guanicoe & L.g. huanacus & \\
\hline AY535265 & GGCH07 & Lama guanicoe & L.g. huanacus & \\
\hline AY535264 & GGCH06 & Lama guanicoe & L.g. huanacus & \\
\hline AY535263 & GGCH05 & Lama guanicoe & L.g. huanacus & \\
\hline AY535262 & GGCH04 & Lama guanicoe & L.g. huanacus & \\
\hline AY535261 & GGCH03 & Lama guanicoe & L.g. huanacus & \\
\hline AY535260 & GGCH02 & Lama guanicoe & L.g. huanacus & \\
\hline AY535259 & GGCH01 & Lama guanicoe & L.g. huanacus & \\
\hline AY535258 & GGPE03 & Lama guanicoe & L.g. cacsilensis & \\
\hline AY535257 & GGPE02 & Lama guanicoe & L.g. cacsilensis & \\
\hline AY535256 & GGPE01 & Lama guanicoe & L.g. cacsilensis & \\
\hline AY535255 & VVAR_MA & Vicugna vicugna & V.v. vicugna & Argentina \\
\hline AY535254 & VVCH_MA & Vicugna vicugna & V.v. mensalis & Chile \\
\hline AY535253 & LGAR_MA & Lama glama & L.glama argentina & \\
\hline AY535252 & LGCA_MA & Lama glama & L.glama ccara & \\
\hline AY535251 & LGCH_MA & Lama glama & L. glama chaku & \\
\hline AY535250 & LPHU_MA & Lama pacos & L.pacos huacaya & \\
\hline AY535249 & LPSU_MA & Lama pacos & L.pacos suri & \\
\hline \multicolumn{5}{|l|}{ D-loop } \\
\hline AY856341 & VV1_MA & Vicugna vicugna & V.v. vicugna & Chile \\
\hline AY856340 & VV2_MA & Vicugna vicugna & V.v. vicugna & Chile \\
\hline AY856339 & VV3_MA & Vicugna vicugna & V.v. vicugna & Chile \\
\hline AY856338 & VM4_MA & Vicugna vicugna & V.v. mensalis & Chile \\
\hline AY856337 & VM5_MA & Vicugna vicugna & V.v. mensalis & Chile \\
\hline AY856336 & VM6_MA & Vicugna vicugna & V.v. mensalis & Chile \\
\hline AY856335 & VM7_MA & Vicugna vicugna & V.v. mensalis & Chile \\
\hline AY856334 & VM8_MA & Vicugna vicugna & V.v. mensalis & Chile \\
\hline AY856333 & VM9_MA & Vicugna vicugna & V.v. mensalis & Chile \\
\hline AY856332 & VM10_MA & Vicugna vicugna & V.v. mensalis & Chile \\
\hline
\end{tabular}




\begin{tabular}{|c|c|c|c|c|}
\hline AY856331 & VM11_MA & Vicugna vicugna & V.v. mensalis & Chile \\
\hline AY856330 & VM12_MA & Vicugna vicugna & V.v. mensalis & Chile \\
\hline AY856329 & VM13_MA & Vicugna vicugna & V.v. mensalis & Chile \\
\hline AY856328 & VM14_MA & Vicugna vicugna & V.v. mensalis & Chile \\
\hline AY856327 & VM15_MA & Vicugna vicugna & V.v. mensalis & Chile \\
\hline AY856326 & VM16_MA & Vicugna vicugna & V.v. mensalis & Chile \\
\hline AY856325 & VM17_MA & Vicugna vicugna & V.v. mensalis & Chile \\
\hline AY856324 & VM18_MA & Vicugna vicugna & V.v. mensalis & Chile \\
\hline AY856323 & VV19_MA & Vicugna vicugna & V.v. vicugna & Argentina \\
\hline AY856322 & VV20_MA & Vicugna vicugna & V.v. vicugna & Argentina \\
\hline AY856321 & VV21_MA & Vicugna vicugna & V.v. vicugna & Argentina \\
\hline AY856320 & VV22_MA & Vicugna vicugna & V.v. vicugna & Argentina \\
\hline AY856319 & VV23_MA & Vicugna vicugna & V.v. vicugna & Argentina \\
\hline AY856318 & VV24_MA & Vicugna vicugna & V.v. vicugna & Chile \\
\hline AY856317 & VV25_MA & Vicugna vicugna & V.v. vicugna & Chile \\
\hline AY856316 & VV26_MA & Vicugna vicugna & V.v. vicugna & Chile \\
\hline AY856315 & VV27_MA & Vicugna vicugna & V.v. vicugna & Chile \\
\hline AY856314 & VV28_MA & Vicugna vicugna & V.v. vicugna & Chile \\
\hline AY856313 & VV29_MA & Vicugna vicugna & V.v. vicugna & Chile \\
\hline AY856312 & VV30_MA & Vicugna vicugna & V.v. vicugna & Chile \\
\hline AY856311 & VV31_MA & Vicugna vicugna & V.v. vicugna & Chile \\
\hline AY856310 & VV32_MA & Vicugna vicugna & V.v. vicugna & Chile \\
\hline AY856309 & VV33_MA & Vicugna vicugna & V.v. vicugna & Argentina \\
\hline AY856308 & VV34_MA & Vicugna vicugna & V.v. vicugna & Argentina \\
\hline AY856307 & VV35_MA & Vicugna vicugna & V.v. vicugna & Argentina \\
\hline AY856306 & VV36_MA & Vicugna vicugna & V.v. vicugna & Argentina \\
\hline AY856305 & VV37_MA & Vicugna vicugna & V.v. vicugna & Argentina \\
\hline AY856304 & VV38_MA & Vicugna vicugna & V.v. vicugna & Argentina \\
\hline AY856303 & VM39_MA & Vicugna vicugna & V.v. mensalis & Peru \\
\hline AY856302 & VM40_MA & Vicugna vicugna & V.v. mensalis & Peru \\
\hline AY856301 & VM41_MA & Vicugna vicugna & V.v. mensalis & Peru \\
\hline AY856300 & VM42_MA & Vicugna vicugna & V.v. mensalis & Peru \\
\hline AY856299 & VM43_MA & Vicugna vicugna & V.v. mensalis & Peru \\
\hline AY856298 & VM44_MA & Vicugna vicugna & V.v. mensalis & Peru \\
\hline AY856297 & VM45_MA & Vicugna vicugna & V.v. mensalis & Peru \\
\hline AY856296 & VM46_MA & Vicugna vicugna & V.v. mensalis & Peru \\
\hline AY856295 & VM47_MA & Vicugna vicugna & V.v. mensalis & Peru \\
\hline AY856294 & VM48_MA & Vicugna vicugna & V.v. mensalis & Peru \\
\hline AY856293 & VM49_MA & Vicugna vicugna & V.v. mensalis & Peru \\
\hline AY856292 & VM50_MA & Vicugna vicugna & V.v. mensalis & Peru \\
\hline AY856291 & VM51_MA & Vicugna vicugna & V.v. mensalis & Peru \\
\hline AY856290 & VM52_MA & Vicugna vicugna & V.v. mensalis & Peru \\
\hline AY856289 & VM53_MA & Vicugna vicugna & V.v. mensalis & Peru \\
\hline AY856288 & VM54_MA & Vicugna vicugna & V.v. mensalis & Peru \\
\hline AY856287 & VM55_MA & Vicugna vicugna & V.v. mensalis & Peru \\
\hline AY856286 & VM56_MA & Vicugna vicugna & V.v. mensalis & Peru \\
\hline AY856285 & VM57_MA & Vicugna vicugna & V.v. mensalis & Peru \\
\hline AY856284 & VM58_MA & Vicugna vicugna & V.v. mensalis & Peru \\
\hline AY856283 & VM59_MA & Vicugna vicugna & V.v. mensalis & Peru \\
\hline AY856282 & VM60_MA & Vicugna vicugna & V.v. mensalis & Peru \\
\hline AY856281 & VM61_MA & Vicugna vicugna & V.v. mensalis & Peru \\
\hline AY856280 & VM62_MA & Vicugna vicugna & V.v. mensalis & Peru \\
\hline AY856279 & VM63_MA & Vicugna vicugna & V.v. mensalis & Peru \\
\hline
\end{tabular}




\begin{tabular}{|c|c|c|c|c|}
\hline AY856278 & VM64_MA & Vicugna vicugna & V.v. mensalis & Peru \\
\hline AY856277 & VM65_MA & Vicugna vicugna & V.v. mensalis & Peru \\
\hline AY856276 & VM66_MA & Vicugna vicugna & V.v. mensalis & Peru \\
\hline AY856275 & VM67_MA & Vicugna vicugna & V.v. mensalis & Peru \\
\hline AY856274 & VM68_MA & Vicugna vicugna & V.v. mensalis & Peru \\
\hline AY856273 & VM69_MA & Vicugna vicugna & V.v. mensalis & Peru \\
\hline AY856272 & VM70_MA & Vicugna vicugna & V.v. mensalis & Peru \\
\hline AY856271 & VM71_MA & Vicugna vicugna & V.v. mensalis & Peru \\
\hline AY856270 & VM72_MA & Vicugna vicugna & V.v. mensalis & Peru \\
\hline AY856269 & GG1_MA & L. guanicoe & L.g.guanicoe & Chile \\
\hline AY856268 & GG2_MA & L. guanicoe & L.g.guanicoe & Chile \\
\hline AY856267 & GG3_MA & L. guanicoe & L.g.guanicoe & Chile \\
\hline AY856266 & GG4_MA & L. guanicoe & L.g.guanicoe & Chile \\
\hline AY856265 & GG5_MA & L. guanicoe & L.g.guanicoe & Chile \\
\hline AY856264 & GG6_MA & L. guanicoe & L.g.guanicoe & Chile \\
\hline AY856263 & GG7_MA & L. guanicoe & L.g.guanicoe & Chile \\
\hline AY856262 & GG8_MA & L. guanicoe & L.g.guanicoe & Chile \\
\hline AY856261 & GG9_MA & L. guanicoe & L.g.guanicoe & Chile \\
\hline AY856260 & GG10_MA & L. guanicoe & L.g.guanicoe & Chile \\
\hline AY856259 & GG11_MA & L. guanicoe & L.g.guanicoe & Chile \\
\hline AY856258 & GG12_MA & L. guanicoe & L.g.guanicoe & Chile \\
\hline AY856257 & GG13_MA & L. guanicoe & L.g.guanicoe & Chile \\
\hline AY856256 & GG14_MA & L. guanicoe & L.g.guanicoe & Chile \\
\hline AY856255 & GG15_MA & L. guanicoe & L.g.guanicoe & Chile \\
\hline AY856254 & GG16_MA & L. guanicoe & L.g.guanicoe & Chile \\
\hline AY856253 & GG17_MA & L. guanicoe & L.g.guanicoe & Chile \\
\hline AY856252 & GG18_MA & L. guanicoe & L.g.guanicoe & Chile \\
\hline AY856251 & GG19_MA & L. guanicoe & L.g.guanicoe & Chile \\
\hline AY856250 & GG20_MA & L. guanicoe & L.g.guanicoe & Chile \\
\hline AY856249 & GG21_MA & L. guanicoe & L.g.guanicoe & Chile \\
\hline AY856248 & GG22_MA & L. guanicoe & L.g.guanicoe & Chile \\
\hline AY856247 & GG23_MA & L. guanicoe & L.g.guanicoe & Chile \\
\hline AY856246 & GG24_MA & L. guanicoe & L.g.guanicoe & Chile \\
\hline AY856245 & GG25_MA & L. guanicoe & L.g.guanicoe & Chile \\
\hline AY856244 & GG26_MA & L. guanicoe & L.g.guanicoe & Chile \\
\hline AY856243 & GG27_MA & L. guanicoe & L.g.guanicoe & Chile \\
\hline AY856242 & GG28_MA & L. guanicoe & L.g.guanicoe & Chile \\
\hline AY856241 & GG29_MA & L. guanicoe & L.g.guanicoe & Chile \\
\hline AY856240 & GG30_MA & L. guanicoe & L.g.guanicoe & Argentina \\
\hline AY856239 & GG31_MA & L. guanicoe & L.g.guanicoe & Argentina \\
\hline AY856238 & GG32_MA & L. guanicoe & L.g.guanicoe & Argentina \\
\hline AY856237 & GG33_MA & L. guanicoe & L.g.guanicoe & Argentina \\
\hline AY856236 & GG34_MA & L. guanicoe & L.g.guanicoe & Argentina \\
\hline AY856235 & GG35_MA & L. guanicoe & L.g.guanicoe & Argentina \\
\hline AY856234 & GG36_MA & L. guanicoe & L.g.guanicoe & Argentina \\
\hline AY856233 & GG37_MA & L. guanicoe & L.g.guanicoe & Argentina \\
\hline AY856232 & GG38_MA & L. guanicoe & L.g.guanicoe & Argentina \\
\hline AY856231 & GG39_MA & L. guanicoe & L.g.guanicoe & Argentina \\
\hline AY856230 & GG40_MA & L. guanicoe & L.g.guanicoe & Argentina \\
\hline AY856229 & GG41_MA & L. guanicoe & L.g.guanicoe & Argentina \\
\hline AY856228 & GG42_MA & L. guanicoe & L.g.guanicoe & Argentina \\
\hline AY856227 & GG43_MA & L. guanicoe & L.g.guanicoe & Argentina \\
\hline AY856226 & GG44_MA & L. guanicoe & L.g.guanicoe & Argentina \\
\hline
\end{tabular}




\begin{tabular}{|c|c|c|c|c|}
\hline AY856225 & GG45_MA & L. guanicoe & L.g.guanicoe & Argentina \\
\hline AY856224 & GG46_MA & L. guanicoe & L.g.guanicoe & Argentina \\
\hline AY856223 & GG47_MA & L. guanicoe & L.g.guanicoe & Argentina \\
\hline AY856222 & GH48_MA & L. guanicoe & L.g.huanacus & Chile \\
\hline AY856221 & GH49_MA & L. guanicoe & L.g.huanacus & Chile \\
\hline AY856220 & GH50_MA & L. guanicoe & L.g.huanacus & Chile \\
\hline AY856219 & GH51_MA & L. guanicoe & L.g.huanacus & Chile \\
\hline AY856218 & GH52_MA & L. guanicoe & L.g.huanacus & Chile \\
\hline AY856217 & GH53_MA & L. guanicoe & L.g.huanacus & Chile \\
\hline AY856216 & GG54_MA & L. guanicoe & L.g.guanicoe & Argentina \\
\hline AY856215 & GG55_MA & L. guanicoe & L.g.guanicoe & Argentina \\
\hline AY856214 & GG56_MA & L. guanicoe & L.g.guanicoe & Argentina \\
\hline AY856213 & GG57_MA & L. guanicoe & L.g.guanicoe & Argentina \\
\hline AY856212 & GG58_MA & L. guanicoe & L.g.guanicoe & Argentina \\
\hline AY856211 & GH59_MA & L. guanicoe & L.g.huanacus & Chile \\
\hline AY856210 & GH60_MA & L. guanicoe & L.g.huanacus & Chile \\
\hline AY856209 & GH61_MA & L. guanicoe & L.g.huanacus & Chile \\
\hline AY856208 & GH62_MA & L. guanicoe & L.g.huanacus & Chile \\
\hline AY856207 & GH63_MA & L. guanicoe & L.g.huanacus & Chile \\
\hline AY856206 & GH64_MA & L. guanicoe & L.g.huanacus & Chile \\
\hline AY856205 & GH65_MA & L. guanicoe & L.g.huanacus & Chile \\
\hline AY856204 & GH66_MA & L. guanicoe & L.g.huanacus & Chile \\
\hline AY856203 & GH67_MA & L. guanicoe & L.g.huanacus & Chile \\
\hline AY856202 & GH68_MA & L. guanicoe & L.g.huanacus & Chile \\
\hline AY856201 & GH69_MA & L. guanicoe & L.g.huanacus & Chile \\
\hline AY856200 & GH70_MA & L. guanicoe & L.g.huanacus & Chile \\
\hline AY856199 & GH71_MA & L. guanicoe & L.g.huanacus & Chile \\
\hline AY856198 & GH72_MA & L. guanicoe & L.g.huanacus & Chile \\
\hline AY856197 & GH73_MA & L. guanicoe & L.g.huanacus & Chile \\
\hline AY856196 & GH74_MA & L. guanicoe & L.g.huanacus & Chile \\
\hline AY856195 & GH75_MA & L. guanicoe & L.g.huanacus & Chile \\
\hline AY856194 & GH76_MA & L. guanicoe & L.g.huanacus & Chile \\
\hline AY856193 & GH77_MA & L. guanicoe & L.g.huanacus & Chile \\
\hline AY856192 & GH78_MA & L. guanicoe & L.g.huanacus & Chile \\
\hline AY856191 & GH79_MA & L. guanicoe & L.g.huanacus & Chile \\
\hline AY856190 & GH80_MA & L. guanicoe & L.g.huanacus & Chile \\
\hline AY856189 & GH81_MA & L. guanicoe & L.g.huanacus & Chile \\
\hline AY856188 & GH82_MA & L. guanicoe & L.g.huanacus & Chile \\
\hline AY856187 & GH83_MA & L. guanicoe & L.g.huanacus & Chile \\
\hline AY856186 & GH84_MA & L. guanicoe & L.g.huanacus & Chile \\
\hline AY856185 & GH85_MA & L. guanicoe & L.g.huanacus & Chile \\
\hline AY856184 & GH86_MA & L. guanicoe & L.g.huanacus & Chile \\
\hline AY856183 & GH87_MA & L. guanicoe & L.g.huanacus & Chile \\
\hline AY856182 & GH88_MA & L. guanicoe & L.g.huanacus & Chile \\
\hline AY856181 & GH89_MA & L. guanicoe & L.g.huanacus & Chile \\
\hline AY856180 & GV90_MA & L. guanicoe & L.g.voglii & Bolivia \\
\hline AY856179 & GV91_MA & L. guanicoe & L.g.voglii & Bolivia \\
\hline AY856178 & GV92_MA & L. guanicoe & L.g.voglii & Bolivia \\
\hline AY856177 & GV93_MA & L. guanicoe & L.g.voglii & Bolivia \\
\hline AY856176 & GV94_MA & L. guanicoe & L.g.voglii & Bolivia \\
\hline AY856175 & GV95_MA & L. guanicoe & L.g.voglii & Bolivia \\
\hline AY856174 & GV96_MA & L. guanicoe & L.g.voglii & Bolivia \\
\hline AY856173 & GV97_MA & L. guanicoe & L.g.voglii & Bolivia \\
\hline
\end{tabular}




\begin{tabular}{|c|c|c|c|c|}
\hline AY856172 & GC98_MA & L. guanicoe & L.g.cacsilensis & Chile \\
\hline AY856171 & GC99_MA & L. guanicoe & L.g.cacsilensis & Chile \\
\hline AY856170 & GC100_MA & L. guanicoe & L.g.cacsilensis & Chile \\
\hline AY856169 & GC101_MA & L. guanicoe & L.g.cacsilensis & Chile \\
\hline AY856168 & GC102_MA & L. guanicoe & L.g.cacsilensis & Chile \\
\hline AY856167 & GC103_MA & L. guanicoe & L.g.cacsilensis & Chile \\
\hline AY856166 & GC104_MA & L. guanicoe & L.g.cacsilensis & Peru \\
\hline AY856165 & GC105_MA & L. guanicoe & L.g.cacsilensis & Peru \\
\hline AY856164 & GC106_MA & L. guanicoe & L.g.cacsilensis & Peru \\
\hline AY856163 & GC107_MA & L. guanicoe & L.g.cacsilensis & Peru \\
\hline AY856162 & GC108_MA & L. guanicoe & L.g.cacsilensis & Peru \\
\hline AY856161 & GC109_MA & L. guanicoe & L.g.cacsilensis & Peru \\
\hline AY856160 & GC110_MA & L. guanicoe & L.g.cacsilensis & Peru \\
\hline AY856159 & GC111_MA & L. guanicoe & L.g.cacsilensis & Peru \\
\hline AY856158 & GC112_MA & L. guanicoe & L.g.cacsilensis & Peru \\
\hline AY856157 & GC113_MA & L. guanicoe & L.g.cacsilensis & Peru \\
\hline AY856156 & LP1_MA & L. pacos & Huacaya & \\
\hline AY856155 & LP2_MA & L. pacos & Huacaya & \\
\hline AY856154 & LP3_MA & L. pacos & Huасауа & \\
\hline AY856153 & LP4_MA & L. pacos & Нuасауа & \\
\hline AY856152 & LP5_MA & L. pacos & Huасауа & \\
\hline AY856151 & LP6_MA & L. pacos & Ниасауа & \\
\hline AY856150 & LP7_MA & L. pacos & Suri & \\
\hline AY856149 & LP8_MA & L. pacos & Suri & \\
\hline AY856148 & LP9_MA & L. pacos & Suri & \\
\hline AY856147 & LP10_MA & L. pacos & Suri & \\
\hline AY856146 & LP11_MA & L. pacos & Suri & \\
\hline AY856145 & LP12_MA & L. pacos & Suri & \\
\hline AY856144 & LG1_MA & L. glama & Chaku & \\
\hline AY856143 & LG2_MA & L. glama & Chaku & \\
\hline AY856142 & LG3_MA & L. glama & Chaku & \\
\hline AY856141 & LG4_MA & L. glama & Chaku & \\
\hline AY856140 & LG5-MA & L. glama & Ccara & \\
\hline AY856139 & LG6_MA & L. glama & Ccara & \\
\hline AY856138 & LG7_MA & L. glama & Ccara & \\
\hline AY856137 & LG8_MA & L. glama & Ccara & \\
\hline AY856136 & LG9_MA & L. glama & & \\
\hline
\end{tabular}


Supplementary Table S6 Distribution of the four studied species among the unique haplotypes established for 208 Cyt-b sequences through the NJ tree and median joining network analyses

\begin{tabular}{|c|c|c|c|c|c|}
\hline Haplotype & Guanaco & Vicuna & Llama & Alpaca & Total \\
\hline $\mathrm{H} 1$ & 0 & 0 & 3 & 5 & \\
\hline H2 & 2 & 0 & 5 & 0 & \\
\hline Н3 & 0 & 0 & 12 & 1 & \\
\hline $\mathrm{H} 4$ & 0 & 0 & 11 & 1 & \\
\hline H5 & 0 & 0 & 0 & 1 & \\
\hline H6 & 0 & 0 & 1 & 0 & \\
\hline H7 & 0 & 0 & 4 & 0 & \\
\hline H8 & 0 & 0 & 2 & 0 & \\
\hline H9 & 0 & 0 & 0 & 1 & \\
\hline H10 & 0 & 0 & 1 & 0 & \\
\hline H11 & 0 & 0 & 1 & 0 & \\
\hline H12 & 0 & 0 & 1 & 0 & \\
\hline H13 & 0 & 0 & 1 & 0 & \\
\hline H14 & 0 & 0 & 4 & 0 & G1 \\
\hline H15 & 0 & 0 & 4 & 0 & \\
\hline H16 & 0 & 0 & 1 & 0 & \\
\hline H17 & 1 & 0 & 0 & 0 & \\
\hline H18 & 0 & 0 & 0 & 1 & \\
\hline H19 & 0 & 0 & 0 & 1 & \\
\hline H20 & 0 & 0 & 1 & 0 & \\
\hline H21 & 0 & 0 & 1 & 0 & \\
\hline H22 & 0 & 0 & 0 & 1 & \\
\hline H23 & 0 & 0 & 3 & 3 & \\
\hline H24 & 0 & 0 & 1 & 0 & \\
\hline H25 & 0 & 0 & 0 & 1 & \\
\hline H26 & 0 & 0 & 0 & 1 & \\
\hline H27 & 0 & 0 & 1 & 0 & \\
\hline Total & 3 & $\mathbf{0}$ & 58 & 17 & 78 \\
\hline H28 & 0 & 0 & 8 & 1 & \\
\hline H29 & 0 & 0 & 5 & 4 & \\
\hline Н30 & 15 & 0 & 0 & 0 & \\
\hline H31 & 14 & 0 & 0 & 0 & \\
\hline H32 & 0 & 0 & 1 & 1 & \\
\hline H33 & 0 & 0 & 0 & 1 & \\
\hline Н34 & 0 & 0 & 2 & 0 & \\
\hline H35 & 0 & 0 & 1 & 0 & \\
\hline H36 & 1 & 0 & 0 & 0 & G? \\
\hline Н37 & 1 & 0 & 0 & 0 & \\
\hline H38 & 0 & 0 & 1 & 0 & \\
\hline Н39 & 1 & 0 & 1 & 0 & \\
\hline H40 & 1 & 0 & 0 & 0 & \\
\hline H41 & 1 & 0 & 0 & 0 & \\
\hline H42 & 1 & 0 & 0 & 0 & \\
\hline H43 & 1 & 0 & 0 & 0 & \\
\hline H44 & 1 & 0 & 0 & 0 & \\
\hline H45 & 1 & 0 & 0 & 0 & \\
\hline
\end{tabular}




\begin{tabular}{|c|c|c|c|c|c|}
\hline H46 & 1 & 0 & 0 & 0 & \\
\hline H47 & 1 & 0 & 0 & 0 & \\
\hline H48 & 1 & 0 & 0 & 0 & \\
\hline H49 & 1 & 0 & 0 & 0 & \\
\hline H50 & 1 & 0 & 0 & 0 & \\
\hline H51 & 1 & 0 & 0 & 0 & \\
\hline H52 & 1 & 0 & 0 & 0 & \\
\hline H53 & 1 & 0 & 0 & 0 & \\
\hline H54 & 1 & 0 & 0 & 0 & \\
\hline H55 & 1 & 0 & 0 & 0 & \\
\hline H56 & 1 & 0 & 0 & 0 & \\
\hline H57 & 1 & 0 & 0 & 0 & \\
\hline H58 & 0 & 0 & 1 & 0 & \\
\hline Total & 50 & $\mathbf{0}$ & 20 & 7 & 77 \\
\hline H59 & 0 & 9 & 4 & 6 & \multirow{10}{*}{ V1 } \\
\hline H60 & 0 & 14 & 1 & 7 & \\
\hline H61 & 0 & 0 & 1 & 0 & \\
\hline H62 & 0 & 0 & 1 & 0 & \\
\hline H63 & 0 & 4 & 0 & 0 & \\
\hline H64 & 0 & 0 & 1 & 0 & \\
\hline H65 & 0 & 1 & 0 & 0 & \\
\hline H66 & 0 & 1 & 0 & 0 & \\
\hline H67 & 0 & 0 & 0 & 1 & \\
\hline H68 & 0 & 1 & 0 & 0 & \\
\hline Total & 0 & 30 & 8 & 14 & 52 \\
\hline H69 & 0 & 1 & 0 & 0 & $\mathrm{~V} 2$ \\
\hline Total & $\mathbf{0}$ & 1 & 0 & 0 & 1 \\
\hline
\end{tabular}

\begin{tabular}{lrrrrr}
\hline & Guanaco & Vicuna & Llama & Alpaca & \\
G1 & 3 & 0 & 58 & 17 & \\
G2 & 50 & 0 & 20 & 7 & \\
V1 & 0 & 30 & 8 & 14 & \\
V2 & 0 & 1 & 0 & 0 & \\
TOTAL & $\mathbf{5 3}$ & $\mathbf{3 1}$ & $\mathbf{8 6}$ & $\mathbf{3 8}$ & $\mathbf{2 0 8}$
\end{tabular}


Supplementary Table S7 Summary of the distribution of the four studied species among the unique haplotypes established for 406 D-loop sequences through the NJ tree and median joining network analyses

\begin{tabular}{|c|c|c|c|c|c|}
\hline \multicolumn{5}{|l|}{ Left group } & \multirow[b]{2}{*}{ Total } \\
\hline Haplotype & Guanaco & Vicuna & Llama & Alpaca & \\
\hline H1 & 1 & 0 & 4 & 1 & 6 \\
\hline H2 & 0 & 0 & 0 & 2 & 2 \\
\hline H3 & 0 & 0 & 17 & 2 & 19 \\
\hline $\mathrm{H} 4$ & 3 & 0 & 16 & 3 & 22 \\
\hline H5 & 1 & 0 & 10 & 2 & 13 \\
\hline H6 & 0 & 0 & 5 & 3 & 8 \\
\hline H7 & 0 & 0 & 6 & 0 & 6 \\
\hline H8 & 0 & 0 & 4 & 0 & 4 \\
\hline H9 & 0 & 0 & 11 & 2 & 13 \\
\hline H10 & 0 & 0 & 0 & 1 & 1 \\
\hline H11 & 0 & 0 & 1 & 0 & 1 \\
\hline H12 & 0 & 0 & 1 & 0 & 1 \\
\hline H13 & 0 & 0 & 0 & 1 & 1 \\
\hline H14 & 1 & 0 & 0 & 0 & 1 \\
\hline H15 & 2 & 0 & 0 & 0 & 2 \\
\hline H16 & 0 & 0 & 1 & 0 & 1 \\
\hline H17 & 0 & 0 & 1 & 0 & 1 \\
\hline H18 & 0 & 0 & 5 & 0 & 5 \\
\hline H19 & 0 & 0 & 1 & 0 & 1 \\
\hline H20 & 0 & 0 & 0 & 1 & 1 \\
\hline H21 & 0 & 0 & 1 & 0 & 1 \\
\hline H22 & 0 & 0 & 1 & 0 & 1 \\
\hline H23 & 0 & 0 & 1 & 0 & 1 \\
\hline H24 & 2 & 0 & 0 & 0 & 2 \\
\hline H25 & 0 & 0 & 1 & 0 & 1 \\
\hline H26 & 0 & 0 & 1 & 0 & 1 \\
\hline H27 & 0 & 0 & 4 & 0 & 4 \\
\hline H28 & 0 & 0 & 1 & 0 & 1 \\
\hline H29 & 0 & 0 & 1 & 0 & 1 \\
\hline H30 & 0 & 0 & 1 & 0 & 1 \\
\hline H31 & 0 & 0 & 1 & 0 & 1 \\
\hline H32 & 0 & 0 & 0 & 1 & 1 \\
\hline H33 & 0 & 0 & 0 & 1 & 1 \\
\hline H34 & 0 & 0 & 10 & 2 & 12 \\
\hline $\begin{array}{l}\text { Total } \\
\text { Right } \\
\text { group }\end{array}$ & 10 & $\mathbf{0}$ & 106 & 22 & \\
\hline H35 & 46 & 0 & 2 & 0 & 48 \\
\hline H36 & 23 & 0 & 0 & 0 & 23 \\
\hline H37 & 16 & 0 & 0 & 0 & 16 \\
\hline H38 & 8 & 0 & 0 & 0 & 8 \\
\hline H39 & 6 & 0 & 0 & 0 & 6 \\
\hline $\mathrm{H} 40$ & 5 & 0 & 0 & 0 & 5 \\
\hline
\end{tabular}




\begin{tabular}{|c|c|c|c|c|c|}
\hline H41 & 3 & 0 & 0 & 0 & 3 \\
\hline $\mathrm{H} 42$ & 4 & 0 & 0 & 0 & 4 \\
\hline H43 & 2 & 0 & 0 & 0 & 2 \\
\hline H44 & 1 & 0 & 0 & 0 & 1 \\
\hline H45 & 1 & 0 & 0 & 0 & 1 \\
\hline H46 & 0 & 0 & 0 & 1 & 1 \\
\hline H47 & 1 & 0 & 0 & 0 & 1 \\
\hline H48 & 1 & 0 & 0 & 0 & 1 \\
\hline H49 & 1 & 0 & 0 & 0 & 1 \\
\hline H50 & 1 & 0 & 0 & 0 & 1 \\
\hline H51 & 1 & 0 & 0 & 0 & 1 \\
\hline H52 & 1 & 0 & 0 & 0 & 1 \\
\hline H53 & 1 & 0 & 0 & 0 & 1 \\
\hline H54 & 1 & 0 & 0 & 0 & 1 \\
\hline H55 & 1 & 0 & 0 & 0 & 1 \\
\hline H56 & 1 & 0 & 0 & 0 & 1 \\
\hline H57 & 1 & 0 & 0 & 0 & 1 \\
\hline H58 & 1 & 0 & 0 & 0 & 1 \\
\hline H59 & 5 & 0 & 0 & 0 & 5 \\
\hline H60 & 1 & 0 & 0 & 0 & 1 \\
\hline H61 & 1 & 0 & 0 & 0 & 1 \\
\hline Total & 134 & 0 & 2 & 1 & \\
\hline \multicolumn{6}{|l|}{ V1 } \\
\hline H62 & 0 & 51 & 3 & 6 & 60 \\
\hline H63 & 0 & 2 & 2 & 3 & 7 \\
\hline H64 & 0 & 3 & 0 & 1 & 4 \\
\hline H65 & 0 & 0 & 0 & 1 & 1 \\
\hline H66 & 0 & 0 & 1 & 3 & 4 \\
\hline H67 & 0 & 0 & 1 & 1 & 2 \\
\hline H68 & 0 & 0 & 0 & 3 & 3 \\
\hline H69 & 0 & 0 & 1 & 0 & 1 \\
\hline H70 & 0 & 0 & 1 & 0 & 1 \\
\hline H71 & 0 & 2 & 0 & 0 & 2 \\
\hline H72 & 0 & 3 & 0 & 3 & 6 \\
\hline H73 & 0 & 4 & 0 & 0 & 4 \\
\hline H74 & 0 & 2 & 0 & 0 & 2 \\
\hline H75 & 0 & 2 & 0 & 0 & 2 \\
\hline H76 & 0 & 2 & 0 & 0 & 2 \\
\hline H77 & 0 & 0 & 0 & 1 & 1 \\
\hline H78 & 0 & 1 & 0 & 0 & 1 \\
\hline H79 & 0 & 1 & 0 & 0 & 1 \\
\hline H80 & 0 & 1 & 0 & 0 & 1 \\
\hline H81 & 0 & 1 & 0 & 0 & 1 \\
\hline H82 & 0 & 1 & 0 & 0 & 1 \\
\hline H83 & 0 & 1 & 0 & 0 & 1 \\
\hline H84 & 0 & 1 & 0 & 0 & 1 \\
\hline H85 & 0 & 1 & 0 & 0 & 1 \\
\hline H86 & 0 & 1 & 0 & 0 & 1 \\
\hline H87 & 0 & 1 & 0 & 0 & 1 \\
\hline H101 & 0 & 0 & 1 & 0 & 1 \\
\hline Total & 0 & 81 & 10 & 22 & \\
\hline \multicolumn{6}{|l|}{ V2 } \\
\hline H88 & 0 & 1 & 0 & 0 & 1 \\
\hline
\end{tabular}




\begin{tabular}{lllll|l} 
H89 & 0 & 1 & 0 & 0 & 1 \\
H90 & 0 & 2 & 0 & 0 & 2 \\
H91 & 0 & 1 & 0 & 0 & 1 \\
H92 & 0 & 1 & 0 & 0 & 1 \\
H93 & 0 & 1 & 0 & 0 & 1 \\
H94 & 0 & 1 & 0 & 0 & 1 \\
H95 & 0 & 1 & 0 & 0 & 1 \\
H96 & 0 & 2 & 0 & 0 & 2 \\
H97 & 0 & 3 & 0 & 0 & 3 \\
H98 & 0 & 2 & 0 & 0 & 2 \\
H99 & 0 & 1 & 0 & 0 & 1 \\
H100 & 0 & 1 & 0 & 0 & 1 \\
\hline Total & $\mathbf{0}$ & $\mathbf{1 8}$ & $\mathbf{0}$ & $\mathbf{0}$ & \\
\hline
\end{tabular}

Total Guanaco Vicuna Llama Alpaca

$\begin{array}{lllll}\text { Left } & 10 & 0 & 106 & 22\end{array}$

$\begin{array}{lllll}\text { Right } & 134 & 0 & 2 & 1\end{array}$

V1

V2

$\begin{array}{llll}0 & 81 & 10 & 22\end{array}$

TOTAL

$\begin{array}{llll}144 & 99 & 118 & 45\end{array}$

$45 \quad 406$ 


\section{MITOCHONDRIAL DNA (mtDNA) GENETIC DIVERSITY OF Vicugna vicugna mensalis IN BOLIVIA.}

Barreta J, Iñíguez V, Sarno, RJ., Gutiérrez-Gil B, Arranz JJ.

En: Fibre production in South American camelids and other fibre animals (pp. 123-130). Wageningen Academic Publishers. ISBN 978-90-8686-727-1. 

ISBN: 978-90-8686-172-9 e-ISBN: 978-90-8686-727-1 DOI: 10.3921/978-90-8686-727-1

Cover photo: Blanca Nieto at

Pacomarca ranch

First published, 2011

\section{Wageningen Academic Publishers}

The Netherlands, 2011
This work is subject to copyright. AIl rights are reserved, whether the whole or part of

the material is concemed. Nothing ITom this publication may be translated, reproduced, stored in a computerised system or published in any form or in any manner, including electronic, mechanical, reprographic or photographic, without prior written permission ITom the publisher:

Wageningen Academic Publishers

P.O. Box 220

6700 AE Wageningen

The Netherlands

www.WageningenAcademic.com

copyright@WageningenAcademic.com

The individual contributions in this publication and any liabilities arising ITom them remain the responsibility ofthe authors.

The publisher is not responsible for possible damages, which could be a result of content derived ITom this publication. 


\title{
Mitochondrial DNA (mtDNA) genetic diversity of Vicugna vicugna mensalis in Bolivia
}

\author{
J. Barreta ${ }^{I, 2}$, V. Iñiguez ${ }^{2}$, R.J. Sarno ${ }^{3}$, B. Gutiérrez-Gill and J.J. Arranz ${ }^{1}$ \\ ${ }^{1}$ Dpto. Produccion Animal, Universidad de Leon, Spain; jbarretapinto@yahoo.com \\ ${ }^{2}$ Instituto de Biologia Molecular y Biotecnologia, UMSA, La Paz, Bolivia \\ ${ }^{3}$ Department of Biology, Hofstra University Hempstead, NY, USA
}

\section{Abstract}

The vicuña (Vicugna vicugna) is one of two wild South American camelids. Nowadays in Bolivia, there are over 62,869 animals representing $20 \%$ of the world's population breeding in the wild as the only management system. Two subspecies of vicuña are currently accepted, based largely on genetic and size differences: Vicugna vicugna vicugna, distributed in Argentina, Chile and South of Bolivia, and Vicugna vicugna mensalis, disseminated in Peru and North of Bolivia. There are few studies analysing the molecular diversity in Bolivian vicuñas and the aim of this work is to better understand the genetic variability of $V$. v. mensalis distributed in this country. For this purpose, and based on the Vicugna $v$. mensalis published sequence, we analysed the complete cytochrome-b (Cyt-b) (1140 bp) and partial (D-loop) (511 bp) regions of mitochondrial DNA across 35 animals from four different locations within a protected area in the north of Bolivia (Apolobamba). A total of 604 polymorphic sites were found in the Cyt-b gene yielding nine different haplotypes. In the case of the D-loop region, nineteen polymorphic sites were detected and grouped into three haplotypes different. Haplotype diversity $(h)$ reached 0.877 in the Cyt-b gene and 0.211 in the D-loop region. Nucleotide diversity $(\pi)$ ranged from 0.2572 , in the Cyt-b, to 0.00249 , in the D-loop. These results show the need for monitoring programmes in wild populations recovered by massive expansion of the species and the constant evaluation of genetic variation to support conservation and management programmes.

Keywords: camelids, vicuña, mitochondrial DNA, genetic diversity

\section{Introduction}

The vicuña (Vicugna vicugna) is the wild South American camelid which is best adapted to high altitude ecosystems (Bonacic et al., 2002). It has the finest wool in the world (approximately 12 $\mu \mathrm{m}$ in diameter) and there is great interest and demand for its use and exploitation (Kadwell et al., 2001).

In the sixteenth century, the total estimated population of vicuña reached 1.5 to 2 million individuals. However, in the 1960 s and after over-exploitation, the vicuña was declared an endangered species with the number of individuals between 7,000 and 12,000 across its entire range of distribution. After this period, the species was protected in countries with natural populations (Convention for the Conservation and Management of Vicuña originally signed between Peru and Bolivia in 1969, later joined by Argentina, Chile and Ecuador) (Bonacic et al., 2002).

The current geographical distribution ranges from latitudes South $9^{\circ} 30^{\prime}$ to $29^{\circ} 00^{\prime}$ and it is found only above 3,500 metres in altitude on the Peruvian, Bolivian, Chilean and Argentinean treeless grassland steppes called Puna and Altiplano (Renaudeau, 2002). 
The first protected areas were the Pampa Galeras Reserve in Peru and the Andean Fauna Reserve Ulla Ulla in Bolivia, which were later joined by other reserves and national parks. Today, vicuña management is carried out in various forms. At one extreme there is the management in captivity in Argentina. At the other extreme lies the community-based management of vicuñas in the wild such as in Bolivia, which is the sole country to declare that all its vicuñas remain as wild populations. Peru and Chile's policies are situated in the middle with a strong trend towards shifting from community-based management of vicuñas in the wild to semi-captivity (Renaudeau, 2002).

Over a period of 40 years, the vicuña was recovered in great numbers, now estimated to be approximately 306,680 across the highlands and central highlands. Nowadays, the vicuña population has approximately 2,683 individuals in Ecuador, 16,351 in Chile and around 50,000 animals in Argentina. The list is followed by Bolivia with a population of 62,869 and finally Peru with 174,377 individuals (CITES, 2007).

The recovery of these populations led to the 1987 Convention on International Trade in Endangered Species of Fauna and Flora (CITES), which approved the transfer of some populations within Peru and Chile allowing international trade in wool sheared from live vicuñas. In the following years, this regulation was extended to some other populations of vicuña in Argentina and Bolivia (Kadwell et al., 2001).

Two geographic subspecies of the vicuña are recognised: the northern Vicugna vicugna mensalis, and the southern Vicugna vicugna vicugna (Torres, 1992). The approximate dividing line between these two races is $18^{\circ}$ South latitude. V.v. vicugna (Molina, 1872) is found in Bolivia, Argentina and some regions of Chile. This southern subspecies is both larger and lighter in colour than the northern type. V.v. mensalis (Thomas, 1917) occurs in Bolivia, Peru and Chile. This subspecies is darker in colour when compared with the southern vicuna and possesses a white pectoral tuft that is absent in Vicugna v. vicugna individuals (Yacobaccio, 2006).

Based on the study of nuclear genetic markers, Wheeler et al. (2001) reported low levels of genetic diversity within populations and high levels between populations in wild populations of wild Peruvian vicuña (V.v. mensalis). This is a typical situation for species that have suffered a bottleneck in population size and a consequent risk of extinction in the past (Vilá, 2002). Sarno et al. (2004) described low to moderate genetic diversity in Bolivian and Chilean vicuñas, with the northern Bolivian population being the least variable compared with the central and southern Bolivian populations (intermediate levels) and the Chilean population (the most variable). A more extensive study, including populations from Peru, Chile, and Argentina reported a high degree of mitochondrial diversity at the haplotype level and low nucleotide diversity in the species as a whole and within groups. When comparing the two subspecies, the southern populations were found to be more diverse than those in the north (Marin et al., 2007a), supporting the results described by Sarno et al. (2004).

Today, our knowledge on the genetic variability of Bolivian vicunas is limited to the work of Sarno et al. (2004), where a limited number of animals from south, north and central Bolivia were analysed. Although the geographical boundaries for the two vicuña subspecies in Bolivia are unclear, these authors suggest that $V$. v. mensalis would be found distributed mainly in ANMIN-Apolobamba and $V$. v. vicugna in South Lípez. Taking into account the lower level of genetic diversity reported for the northern vicuñas ( $V . v$. mensalis) compared with the southern populations ( V.v. vicugna) (Sarno et al., 2004; Marín et al., 2007a) and the rapid demographic expansion suggested for V.v. mensalis (Marín et al., 2007b) we have studied the genetic diversity of mitochondrial DNA (cytochrome-b, Cyt-b, and D-loop regions) in a vicuña 
population localised in ANMIN-Apolobamba, in northern Bolivia. Hence, the aim of this study was to determine whether the degree of genetic diversity for this stock, which is likely to belong to the $V . v$. mensalis group, has achieved a significant recovery as would be expected based on the conservation measures implemented since 1969 (Convention for the Conservation and Management of Vicuña).

\section{Materials and methods}

\section{Sample collection and DNA extraction}

The study included a total of 35 Vicugna v. mensalis individuals from ANMIN-Apolobamba (northern region of Bolivia $18^{\circ} 55^{\prime} \mathrm{S}, 69^{\circ} 4^{\prime} 60 \mathrm{~W}$ ). This reserve has an estimated population of 8,299 vicuñas in an area of $100,000 \mathrm{Ha}(\mathrm{DNCB}, 1996)$, identifying four areas of herding, trapping and shearing: Cañuhuma, Hichucollo, Huacuchani and Ucha Ucha. Adult animals were sampled at random from these four locations (Cañuhuma $n=11$; Hichucollo $n=8$; Huacuchani $n=10$; and Ucha Ucha $n=6$ ). Ear tissue samples were collected from the animals when they were sheared and kept in 'Easy Blood' buffer (Munson, 2000). Genomic DNA isolation was performed from the ear tissue samples $(2-3 \mathrm{~mm})$ with the commercial DNeasy Tissue kit (QIAGEN) following the manufacturer's instructions. A guanaco (Lama guanicoe) was used as reference for the analysis of the Cyt-b gene, whereas a llama (Lama glama) was the reference sample in the analysis of the D-loop region.

\section{Polymerase chain reaction amplification}

The mitochondrial Cyt-b $\approx 1,140 \mathrm{bp})$ and the D-loop region $(\approx 511 \mathrm{bp})$ were amplified by PCR using the primer pairs detailed in Table 1, following Marín et al. (2007b).

The amplification reaction was performed in a total volume of $30 \mu \mathrm{l}$ containing $30 \mathrm{ng}$ of DNA, $1 \mathrm{X}$ magnesium free PCR buffer (Applied Biosystems (AB), Foster City. CA), $2.0 \mathrm{mM} \mathrm{MgCl}, 0.2$ $\mathrm{mM}$ dNTPs, $0.5 \mathrm{mM}$ of each primer and 1.25 U of AmpliTaq Gold (AB). The PCR programme

Table 1. Oligonucleotide sequences used for the amplification and sequencing the mtDNA regions studied in this work (cytochrome-b gene and D-loop region).

\begin{tabular}{|c|c|c|}
\hline Name of primer & Sequence nucleotide & $m t$ DNA region \\
\hline LGlu ARTIO' & 5' TCTAACCACGACTAATGACAT 3' & Cyt-b \\
\hline Hthr ARTIO' & 5' TCCTTTTTCGGCTTACAAGACC 3' & Cyt-b \\
\hline Lthr ARTIO' & 5' GGTCTTGTAAGCCGAAAAAGGA 3' & D-loop \\
\hline HLOOP550G' & 5' ATGGACTGAATAGCACCTTATG 3' & D-loop \\
\hline $\mathrm{L} 400^{2}$ & 5' GGGCTATGTACTCCCATGAGG 3' & Cyt-b \\
\hline LBE- $02^{2}$ & 5' CTCCGTAGATAAAGCCACCC $3{ }^{\prime}$ & Cyt-b \\
\hline CytB3372 & 5' TTCAAGTTTCTAGGAAGGGCG 3' & Cyt-b \\
\hline Lloop0007G ${ }^{2}$ & 5' GTACTAAAAGAAAATATCATGTC 3' & D-loop \\
\hline $\mathrm{H} 362^{2}$ & 5' GGTTTCACGCGGCATGGTGATT 3' & D-loop \\
\hline HI59982 & 5' CCAGCTTCAATTGATTTGACTGCG 3' & D-loop \\
\hline Dloop $747 F^{2}$ & 5' TAAAATCGCCCACACACTTTCC 3' & D-loop \\
\hline
\end{tabular}

\footnotetext{
I Primers used in the PCR fragment amplification and later for sequencing.

2 Internal primers used for sequencing.
} 
consisted of an initial 5 -min denaturation step at $95^{\circ} \mathrm{C}$, followed by 35 cycles of $45 \mathrm{~s}$ at $95^{\circ} \mathrm{C}$, $30 \mathrm{~s}$ at $60^{\circ} \mathrm{C}$ and $45 \mathrm{~s}$ at $72{ }^{\circ} \mathrm{C}$, followed by a final elongation cycle of $5 \mathrm{~min}$ at $72{ }^{\circ} \mathrm{C}$.

\section{Sequence analysis}

The amplified fragments were purified with $4 \mathrm{U}$ of ExoSAPIT (Amersham Biosciences, GE Healthcare) by incubating at $37^{\circ} \mathrm{C}$ for $30 \mathrm{~min}$, followed by an enzyme deactivation phase for $15 \mathrm{~min}$ at $80^{\circ} \mathrm{C}$. Dideoxy sequencing in both directions was performed with the BigDye Terminator v3.1 Cycle Sequencing Kit (Applied Biosystems, Foster City, CA) using the same primers used for fragment amplification. Additional internal primers, which are also given in Table 1, were designed based on the reference sequences for $V . v$. mensalis obtained from GenBank (GenBank Acc N ${ }^{\circ}$ AY535255 for Cyt-b, and GenBank Acc N ${ }^{\circ}$ AY856270 for D-loop region). The sequencing reactions included an initial denaturation step of $96^{\circ} \mathrm{C}$ for $5 \mathrm{~min}$ and 35 cycles of $96^{\circ} \mathrm{C}$ for $20 \mathrm{~s}, 59^{\circ} \mathrm{C}$ for $10 \mathrm{~s}$, and $60^{\circ} \mathrm{C}$ for $4 \mathrm{~min}$. The products of the sequencing reaction were purified using CleanSEQ reagent set (Agencourt Bioscience, Beckman Coulter) and analysed using an ABI3130 DNA Sequencer (Applied Biosystems Foster City CA).

\section{Data analyses}

Using SeqScape v2.5 software (Applied Biosystems, Foster City, CA) the sequences obtained for the 35 animals analysed were aligned and compared with the published sequences (GenBank Acc $\mathrm{N}^{\circ}$ AY535255 and AY856270 for Cyt-b and D-loop regions, respectively) to search for any polymorphisms in the studied fragments. Sequences were aligned using the DNA alignment software (Fluxus technology, 2003-2010) and were visually confirmed. The number of polymorphic sites $(\mathrm{S})$, the average number of differences between pairs of sequences $(\mathrm{P})$, haplotype diversity $(h)$ and nucleotide diversity $(\pi)$ were estimated with DnaSP 4.0 (Rozas, 2009). We generated a median joining network for each of the two studied regions using NETWORK (4.5.1.6) software (Bandelt et al., 1999) in order to display the relationships among the identified haplotypes.

\section{Results}

We obtained data for the complete mitochondrial Cyt-b gene $(1,140 \mathrm{bp})$ and partial D-loop region (511 bp) from 29 and 35 individuals, respectively, which belonged to the four localities from the ANMIN-Apolobamba reserve considered in the present study. The diversity parameters estimated for the two regions are given in Table 2 . Briefly, alignment of the sequences showed $606(52.63 \%)$ polymorphic sites at the Cyt-b gene and $19(3.72 \%)$ polymorphic sites at the D-loop region. These polymorphic sites were grouped into 9 and 3 different haplotypes in the Cyt-b and D-loop regions, respectively. Haplotype diversity $(h)$ was much lower at the D-loop region $(0.2110 \pm 0.0890)$ than in the Cyt-b gene $(0.8770 \pm 0.0340)$ as was the nucleotide diversity $(\pi)(0.0025 \pm 0.0016$ for the D-loop region and $0.2572 \pm 0.0127$ for the Cyt-b gene $)$.

Table 2. Haplotype (gene) diversity ( $h$ ) and nucleotide diversity ( $\pi$ ) estimated for the mtDNA regions studied in this work.

\begin{tabular}{lllll}
\hline & Fragment size (bp) & Haplotypes & $h \pm$ std dev & $\pi \pm$ std dev \\
Cyt-b & 1,140 & 9 & $0.8770 \pm 0.0340$ & $0.2572 \pm 0.0127$ \\
D-loop & $5 \mathrm{II}$ & 3 & $0.2110 \pm 0.0890$ & $0.0025 \pm 0.0016$ \\
\hline
\end{tabular}


The alignment of polymorphic sites identified in the Cyt-b and D-loop regions is shown in Figure 1, where the frequency observed for each haplotype and the localities corresponding to each identified haplotype are also indicated. In the Cyt-b gene (Figure 1a) the 604 segregating sites were distributed in nine different haplotypes. The most frequent haplotype was $\mathrm{H} 1(f=13 / 29)$, which was found in Cañuhuma, followed by $\mathrm{H} 3(f=8 / 13)$ identified in the same locality. For the D-loop region (Figure $1 \mathrm{~b}$ ), there was a dominant haplotype, $\mathrm{H} 1(f=32 / 35)$, which was observed in all localities whereas two other haplotypes, $\mathrm{H} 2$ and $\mathrm{H} 3$, were only found in one of the four localities studied at very low frequency $(f=2 / 35$ and $f=1 / 35$, respectively).

For the Cyt-b gene, the median joining network constructed shows the genealogical relationships among the 9 haplotypes connected through a maximum of 19 mutational steps (Figure 1a). The median joining network obtained for the D-loop sequences establishes the relationship among 3 haplotypes connected through a maximum of 5 mutational steps (Figure 2).

\section{Discussion}

Andean animal populations live in one of the most extreme and variable topographic environments in the world. Hence, ecological factors, together with historic factors may have influenced the patterns of variation of $m t$ DNA shaping the genetic relationships between the current populations. We have analysed here $m t$ DNA sequences from a vicuña population localised in the ANMINApolobamba reserve. Because of their geographical location, these animals are expected to belong to the V.v. mensalis group of vicuñas, which shows lower genetic diversity levels than the V.v. vicugna group according to previous studies (Sarno et al., 2004; Marín et al., 2007a).

Overall, our analyses based on $m t$ DNA sequences showed appreciable genetic variability segregating in the vicuña population analysed. This variation was much higher for the Cyt-b gene $(h=0.8770 ; \pi=0.2572)$ than for the D-loop region $(h=0.2110 ; \pi=0.00249)$, which is surprising taking into account that in most of the works studying $m t$ DNA variability levels across different mammalian genera, the D-loop region is considered a hypervariable region (Pedrosa

\section{A}

\begin{tabular}{|c|c|c|c|}
\hline \multirow[t]{2}{*}{ Haplotypes } & $\begin{array}{r}2345912466391111222233333333333444444445555555556666666677777777788888888889999999999111111111111 \\
875092602571449145569999990456788902246678902357899112447899013445777800114568990000000000111 \\
93689034524890123698435169817831295191942859340151658197098369307565762463334455668122\end{array}$ & $\stackrel{n}{\text { Total }}=29$ & Localities \\
\hline & 2581439581329 & & \\
\hline $\begin{array}{l}\text { Ret. } \\
\text { H1. }\end{array}$ & 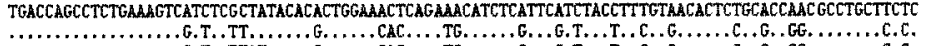 & 13 & $\mathrm{C}$ \\
\hline H2. & ....G.T. TTAT.....G. .....CAC....TG. . & 1 & c \\
\hline H3. & 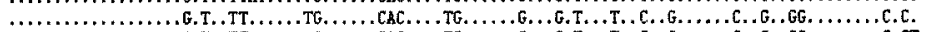 & 8 & c \\
\hline H4. & 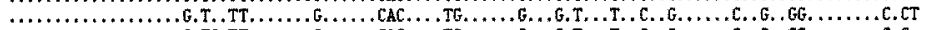 & 1 & H \\
\hline HS. & 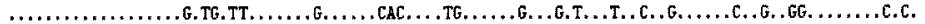 & 2 & H \\
\hline H6. & 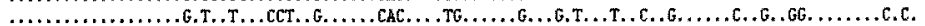 & 1 & I \\
\hline Hา. & 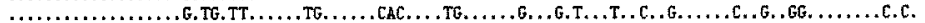 & 1 & I \\
\hline H8. & 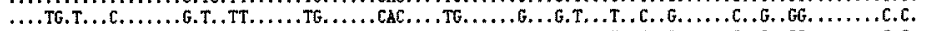 & $i$ & I \\
\hline H9. & 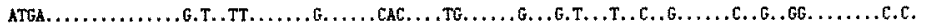 & 1 & U \\
\hline
\end{tabular}

B D-loop

\begin{tabular}{|c|c|c|c|}
\hline Hap lot ypes & $\begin{array}{r}6911122333345556666671122223344 \\
56989037844890478929911233478\end{array}$ & $\begin{array}{c}\mathbf{n}_{1} \\
\text { Total }\end{array}=35$ & Localities \\
\hline Ref. & GGGACCATACTRCTCGATGACTGTCTCTT & & \\
\hline t1. & . MRGATT . ...... T. TAGC,GTC . . C... & 32 & $\mathrm{C}, \mathrm{H}, \mathrm{I}, \mathrm{J}$ \\
\hline H2. & .AAGATT, ...... T.TAGC.GTC.C.CT.. & 2 & $\mathrm{c}$ \\
\hline H3. & ARGATT. .T. A.T.TAGC .GTC . .C. . & 1 & U \\
\hline
\end{tabular}

Figure I. Alignment of polymorphic sites identified across the Cyt-b (a) and D-loop (b) regions analysed in this study. Nucleotide umbering is based on GenBank reference sequences (GenBank Acc N ${ }^{\circ}$ AY535255 for Cyt-b gene and GenBank Acc $N^{\circ}$ AY856270 for D-loop region). Localities code $C=$ Cañuhuma, $H=$ Huacuchani, $I=$ Huchicollo and $U=$ Ucha Ucha. 


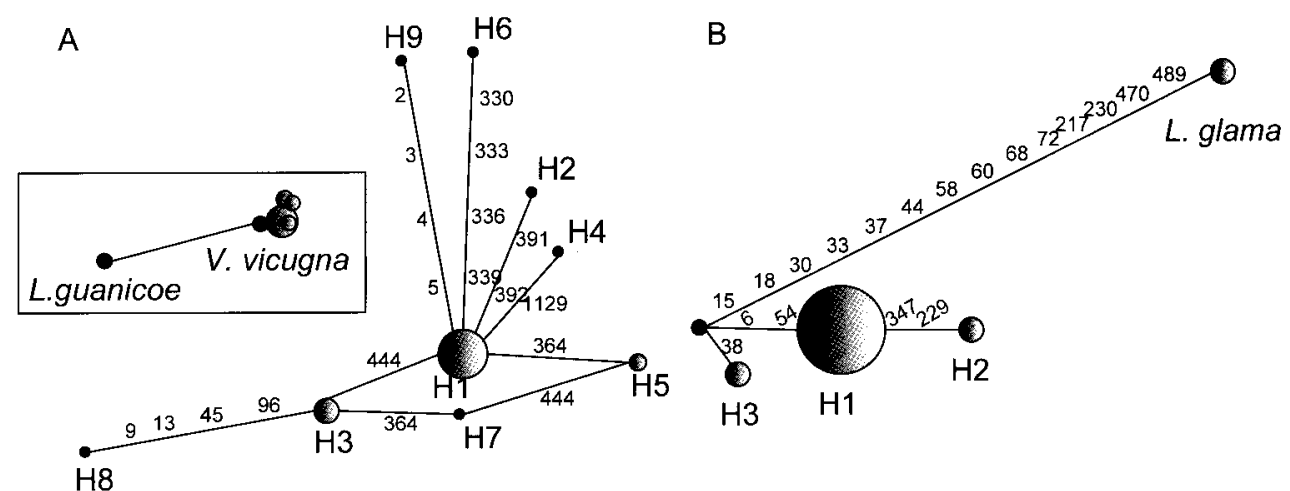

Vicugna vicugna

Figure 2. Median joining network for the analysed vicuña population based on the Cyt-b (a) and D-loop (b) haplotypes identified in the present study. The size of nodes is approximately proportional to their frequency.

et al., 2006; Alter and Palumbi, 2009, Galtier et al., 2009). Interestingly, Marín et al. (2008) found a slightly higher $(h=0.956)$ variability for the Cyt-b gene than for the D-loop region $(h=0.890)$ in guanaco (Lama guanicoe), the other species of wild South American camelids. Further studies should clarify whether this observation occurs in other South American camelids or, alternatively, if it is due to some bias not considered in our analyses.

The haplotype alignment of Cyt-b sequences showed two dominant haplotypes ( $\mathrm{H} 1$ and $\mathrm{H} 3$ ), with only one mutational step between them, from a total of nine. In the D-loop sequence we found a single dominant haplotype (H1) from a total of three. There was also a single mutational step occurring between the dominant D-loop haplotype and the two other haplotypes identified in our resource population. These observations probably indicate that the vicuña populations found in ANMIN-Apolobamba are being subjected to a rapid demographic expansion. In addition, the presence of a large dominant haplotype possibly represents an ancestral lineage, since older haplotypes are expected to have a wider geographic range and frequency (Templeton et al., 1995).

Sarno et al. (2004) found variable levels of genetic diversity for vicuñas sampled across northern, central and southern Bolivia, considering at the same time three combined $m t$ DNA segments involving Cyt-b gene, D-loop region and $16 \mathrm{Ss}$. The northern vicuñas analysed in this study, which are also from the ANMIN-Apolobamba reserve, showed null haplotype and nucleotide diversity, whereas central and southern vicuñas showed increasing levels of genetic diversity. In general, we have found higher levels of genetic diversity across the vicuñas localised in ANMINApolobamba, although a direct comparison of results is not easy. The observed differences are likely due to the larger sample population analysed in the current study. In addition, the inherent differences in genetic variability across the studied regions may influence the results. In this regard, we observed a large variation of the genetic variability across the complete sequence of the Cyt-B gene $(1140 \mathrm{pb})$, with low variability in the first third of the gene $(\pi=0.0017$, considering $1-325 \mathrm{pb})$ when compared with the second half of the gene $(\pi=0.3712$, considering $326-1140 \mathrm{pb})$, whereas Sarno et al. (2004) do not detail the position of the $316 \mathrm{pb}$ that they sequenced.

On the other hand, when Sarno et al. (2004) present the joint analysis of northern and central vicuñas, within the V.v. mensalis group, the gene diversity parameters observed $(h=0.395 ; \pi$ $=0.002$ ) show certain levels of genetic diversity and, similar to those observed for D-loop in 
this paper $(h=0.2110 ; \pi=0.0025)$, whereas the $V . v$. vicugna group showed a slightly higher variability ( $h=0.524 ; \pi=0.008$ ), although still lower than that observed in the resource population analysed here $(h=0.8770 ; \pi=0.2572)$. The joint analysis of the Cyt-b, D-loop and s16 regions presented by Sarno et al. (2004) can also make it difficult to compare these two studies.

The genetic variability of the D-loop region reported in V.v. mensalis vicuñas ( $h=0.7350$; $\pi=0.0082$ ) from Perú and Chile (Marin et al., 2007) is higher than that reported here for the same genomic region $(h=0.2110 ; \pi=0.0025)$. In this case, it seems that the larger number of individuals $(n=261)$ analysed may underlie the higher genetic diversity observed by Marín et al. (2007a). Hence, to increase our knowledge of the genetic diversity of Bolivian vicuñas and compare them with other populations, further research studies should be focused on larger population sizes involving, if possible, both geographical vicuñas groups, $V$. v. mensalis and $V$. v. vicugna. This could help to confirm a clear genetic differentiation between the two subspecies, and the lower variability levels reported for $V$.v. mensalis in all regions, countries and management units studied (Sarno et al., 2004; Marín et al., 2007a). Moreover, analysis of nuclear microsatellite loci could increase the resolution of the genetic differentiation that exists between these two subspecies.

\section{Conclusion}

The levels of genetic diversity achieved in the vicuña populations living in the ANMINApolobamba reserve are significant, considering the remarkable increase in the population of this species in this region during the last years (from 97 individuals in 1965 to 8,000 at present). As a concluding remark, and based on the preliminary results presented here, it seems that the analysis of the Cyt-b gene, especially the last region of its sequence, could be a more useful tool to assess the genetic variability of neighbouring vicuña populations than the analysis of the D-loop region.

\section{Acknowledgements}

We gratefully acknowledge the financial support received from the AECID by projects A/010497/07 and A/017114/08. Julia Barreta's scholarsip is provided by MAEC-AECID.

\section{References}

Alter, S.E. and S.R. Palumbi, 2009. Comparing evolutionary patterns and variability in the mitochondrial Control Region and Cythocrome $b$ in three species of Baleen Whales. Journal of Molecular Evolution, 68: 97-111.

Bandelt H.J., P. Forster and A. Röhl, 1999. Median-joining networks for inferring intraspecific phylogenies. Molecular Biology and Evolution, 16: 37-48.

Bonacic C., D. Macdonald, J. Galaz and R. Sibly, 2002. Density dependence in the camelid Vicugna vicugna: the recovery of a protected population in Chile. Oryx, 36: 118-125.

Fluxus technology, 2003-2010. DNA Alignment Software. Available at: http:/www.fluxus-engineering.com.

Galtier N., B. Nabholz, S. Glémin and G.D.D. Hurst, 2009. Mitochondrial DNA as a marker of molecular diversity: a reappraisal. Molecular Ecology, 18: 4541-4550.

CITES (Convention on International Trade in Endagered Species), 2007. Proposals for amendment of Appendices I and II of CITES convention. Available at: http://www.cites.org/eng/cop/14/prop/E14-P08.pdf.

Kadwell M., M. Fernández, H.F. Stanley, R. Baldi, J.C. Wheeler, R. Rosadio and M.W. Bruford, 2001. Genetic analysis reveals the wild ancestors of the llama and alpaca. Proceedings of the Royal Society of London B, 268: $2575-2584$.

Marin J.C., C.S. Casey, M. Kadwell, K. Yaya, D. Hoces, J. Olazabal, R. Rosario, J. Rodriguez, A. Spotorno, M.W. Bruford and J.C. Wheeler, 2007a. Mitochondrial phylogeography and demographic history of the vicuña: implications for conservation. Heredity, 99: 70-80. 
Marín J.C., B. Zapata, B.A. González, C. Bonacic, J.C. Wheeler, C. Casey, M.W. Bruford, R.E. Palma, E. Poulin, M.A. Alliende and Á.E. Spotorno, 2007b. Sistemática, taxonomía y domesticación de alpacas y llamas: nueva evidencia cromosómica y molecular. Revista Chilena de Historia Natural, 80: 121-140.

Marín J.C., A.E. Spotorno, B.A. González, C. Bonacic, J.C. Wheeler, C.S. Casey, M.W. Bruford, R.E. Palma and E. Poulin, 2008. Mitochondrial DNA variation and systematics of the guanaco (Lama guanicoe, Artiodactyla: Camelidae). Journal of Mammalogy, 89: 269-281.

Molina G.I., 1872. Saggio Sulla Storia Naturale del Chili. Tommaso d'Aquino, Bologna, Italy.

Munson L., 2000. Necropsy procedures for wild animals. With input from: W.B. Karesh, M.F. McEntee, L.J. Lowenstine, M.E. Roelke-Parker, E. Williams and M.H. Woodford (Illustrations by D. Haines). In: L. White and A. Edwards (eds.). Conservation Research in the African rain forests: a technical handbook. Wildlife Conservation Society, New York, NY, USA, pp. 203-224.

Pedrosa S., J.J. Arranz, N. Brito, A. Molina, F. San Primitivo and Y. Bayón, 2006. Mitochondrial diversity and the origin of Iberian sheep. Genetics Selection Evolution, 39: 91-103.

Renaudeau d'Arc, N., 2002. 'Community Management of Vicuña in the Bolivian Altiplano', Procedural Paper presented in March as requirement from MPhil to $\mathrm{PhD}$, School of Development Studies, University of East Anglia, Norwich, UK.

Rozas J., 2009. DNA Sequence Polymorphism Analysis using DnaSP. In: D. Posada (ed.) Bioinformatics for DNA Sequence Analysis; Methods. Molecular Biology Series Vol. 537. Humana Press, Totowa, NJ, USA, pp. 337-350.

Sarno R.J., L. Villalba, C. Bonacic, B. Gonzalez, B. Zapata, D.W. Mac Donald, S.J. O’Brien and W.E. Johnson, 2004. Phylogeography and subspecies assessment of vicuñas in Chile and Bolivia utilizing mtDNA and microsatellite markers: implications for vicuña conservation and management. Conservation Genetics, 5: 89-102.

Templeton A.R., E. Routman and C.A. Phillips, 1995. Separating population structure from population history: a cladistic Analysis of the geographical distribution of mitochondrial DNA haplotypes in the tiger salamander, Ambystoma tigrinum. Genetics, 140: 767-782.

Thomas O., 1917. Preliminary diagnosis of new mammals obtained by the Yale National Society Peruvian Expedition. Smithsonian Misc C 68: 1-3.

Torres H., 1992. Camélidos Silvestres Sudamericanos. Un plan de Accion para su Conservacion. IUCN/CSE South American Camelid Specialist Group, 58 p.

Vilá B.L., 2002. La silvestría de las vicuñas: Una característica esencial para su conservación y manejo. Ecología Austral, 12: 7982 .

DNCB (Dirección Nacional de Conservación de la Biodiversidad), 1996. Censo Nacional de la vicuña en Bolivia. Informe publicado por el Ministerio de Desarrollo Sostenible y Medio Ambiente. La Paz. 55 p.

Yacobaccio H.L., 2006. Variables morfométricas de vicuñas (Vicugna vicugna vicugna) en Cieneguillas. Jujuy. In: B. Vilá (ed.), Investigación conservación y manejo de vicuñas. Proyecto MACS. Buenos Aires, Argentina, pp. 101-112.

Wheeler J.C., M. Fernández, R. Rosadio, D. Hoces, M. Kadwell and M.W. Bruford, 2001. Diversidad Genética y manejo de poblaciones de vicuñas en el Perú. RIVEP Revista de Investigaciones Veterinarias del Perú, Suplemento 1: $170-183$. 


\section{RESUMEN DE RESULTADOS Y DISCUSIÓN GENERAL}

La cría y explotación de camélidos sudamericanos tienen gran importancia en el mantenimiento y desarrollo socioeconómico y cultural de las poblaciones rurales andinas, donde estas especies habitan. Así, el guanaco y la vicuña son componentes fundamentales de la biodiversidad de ecosistemas únicos de Latinoamérica, como son la estepa patagónica y el Altiplano, siendo los herbívoros nativos silvestres de mayor tamaño en dichas áreas. Su rol no se limita a cuestiones ecológicas y biológicas, sino que poseen fibras de alto valor económico y jugaron y juegan un rol fundamental en las culturas de los pueblos originarios (Lichtenstein et al., 2008). Tanto guanacos como vicuñas siempre estuvieron ligados a las antiguas poblaciones humanas que habitaban en la Puna del Perú, y fueron valoradas ya durante el Imperio Inca. Las especies domésticas de camélidos sudamericanos, la llama y alpaca, además de ser importantes hoy en día a nivel cultural por su uso tradicional en ritos y celebraciones (Webster, 1973) son fuente de fibra de importante valor económico para su exportación y de productos cárnicos, que habiendo sido tradicionalmente usados para el autoconsumo, actualmente se están empezando a comercializar con una demanda creciente que alienta la posibilidad de abrirse a mercados exteriores.

La importancia de estas especies en Bolivia es por demás conocida por las características socioculturales de un gran número de familias (54.000) dedicadas a la crianza y explotación de estos camélidos en zonas rurales en este país. En efecto, en Bolivia se encuentra el mayor número de llamas del mundo (> 60 \% de la población; INE, 2008) y la segunda población más grande de alpacas, después de Perú (FAO, 2005). Este país también alberga al $21 \%$ de la población mundial de vicuñas criadas en su hábitat natural (FAO, 2005) y un reducido número de guanacos (< 50) (Cuéllar et al., 2002).

Conocida así la gran importancia de estas especies en Bolivia, la presente Tesis doctoral ha abordado el estudio genético de las poblaciones de camélidos en este país. En primer lugar hemos realizado una valoración de la diversidad genética, a nivel nuclear, de las poblaciones de camélidos domésticos presentes en Bolivia, llamas y alpacas. Dado que estudios similares se han realizado en poblaciones domésticas y salvajes de camélidos sudamericanos en países vecinos como Argentina y Perú principalmente (Bustamante et al., 2002; 2006; Paredes et al., 
2011; Sarno et al., 2004; Maté et al., 2005; Penedo et al., 1998), la falta de este tipo de estudios en poblaciones de camélidos en Bolivia parece relevante, sobre todo ante la necesidad de dar respuesta a dudas que puedan surgir durante el desarrollo de programas de cría que pudieran ser consideradas en estas poblaciones, siendo el análisis y valoración de la diversidad genética la etapa inicial y fundamental para la implementación de cualquier tipo de programa de cría, manejo y conservación de dichas especies. Por tanto, siguiendo el planteamiento clásico de los estudios de diversidad genética con marcadores microsatélites, la presente memoria incluye dos trabajos en los que se analizaron un conjunto importante de este tipo de marcadores sobre un amplio número de muestras de las especies de camélidos domésticos En ambos casos el muestreo se realizó en un amplio rango de distribución geográfica, intentando incluir en nuestro estudio las zonas más importantes de explotación de las especies estudiadas. El análisis de estos marcadores genéticos nucleares nos ha permitido además valorar la estructura poblacional de las llamas y alpacas bolivianas, permitiendo la identificación, según la especie, de una escasa o de una marcada diferenciación poblacional entre los distintos grupos regionales analizados.

Tras el análisis genético a nivel nuclear, se presenta en esta memoria un análisis de la diversidad y estructura genética a nivel mitocondrial de las cuatro especies de camélidos sudamericanos. Intentando presentar una imagen lo más completa posible de las relaciones entras las especies domésticas y sus predecesoras salvajes, además de las poblaciones de llamas y alpacas bolivianas analizadas en los estudios nucleares, se estudiaron poblaciones de vicuñas bolivianas y, dado el escaso número de guanacos presentes hoy en día en este país, un grupo de guanacos del sur de Chile. Un análisis adicional con secuencias de ADNmt disponibles públicamente, y recogidas en la base de datos de GenBank, nos permitió conocer las relaciones filogenéticas y el grado de diferenciación entre las poblaciones de camélidos bolivianos y de éstas con otras procedentes de países vecinos.

Presentamos a continuación un breve resumen de los resultados presentados en cada uno de estos trabajos, así como una discusión de los mismos. 


\section{OBJETIVO 1: Análisis de la diversidad genética de poblaciones de llamas y alpacas bolivianas usando marcadores microsatélites.}

Los dos trabajos presentados en relación al estudio de la diversidad y la estructura genética de llamas y alpacas bolivianas se basaron en el análisis de marcadores microsatélites.

La alta informatividad de los marcadores microsatélites inicialmente analizados en ambas especies ha demostrado, una vez más, la validez de estos marcadores genéticos para realizar estudios de diversidad en poblaciones animales, tal y como se comentaba en la Revisión bibliográfica. Además, como se señala en uno de los trabajos, la información aportada por estos estudios en relación al número de alelos por marcador, el nivel de heterocigosis la presencia de alelos nulos o de alelos privados de poblaciones, aporta un material de gran utilidad a la hora de seleccionar marcadores microsatélites para distintos fines, ya sea realizar análisis de filogenia o paternidad de forma sistemática en las poblaciones estudiadas, o para el planteamiento en las mismas de futuros estudios de genética de poblaciones y filogeografía o de investigaciones forenses (Marín et al., 2009). En relación a este último punto, es interesante el caso presentado por Di Rocco et al. (2011) en el que se pone de manifiesto que el genotipado de un reducido número de marcadores microsatélite es suficiente, frente a los resultados no concluyentes derivados del análisis de la secuencia del ADNmt, para detectar el tráfico ilegal de camélidos y asignar unas muestras a una especie de camélidos sudamericanos determinada.

En los dos estudios de diversidad genética incluidos en esta memoria los marcadores analizados fueron genotipados mediante la técnica de la PCR-multiplex. Los marcadores comunes analizados en alpacas y llamas fueron amplificados siguiendo protocolos similares, con pequeñas variaciones. Aunque la selección inicial de los marcadores se basó en aquellos ya descritos en otros estudios realizados en camélidos (Lang et al., 1996; Penedo et al., 1999a,b; Bustamante et al., 2003; Obreque et al., 1999; Munyard et al., 2009), los protocolos obtenidos tras la optimización de estas reacciones de amplificación conjunta de marcadores y la posterior multicarga de las reacciones suponen en sí mismos un resultado importante derivado de la presente Tesis Doctoral, por las posibilidades directas de aplicación para 
estudiar otras poblaciones de camélidos domésticos y salvajes. Esto además ofrece la oportunidad de comparar los resultados observados, no solo entre poblaciones diferentes de la misma especie, sino también entre distintas especies, y valorar aspectos tan destacables como el grado de hibridación existente en algunas de estas especies y las diferencias en cuanto a niveles de variabilidad genética en poblaciones simpátricas.

Para los estudios de diversidad genética y de estructura de poblaciones presentados para llamas y alpacas, la planificación de los muestreos se realizó, en ambos casos, con el fin de abarcar el más amplio rango posible de distribución geográfica de estas especies en Bolivia, además de intentar incluir aquellas zonas de localización que son más relevantes a nivel productivo para cada una de ellas. En este sentido es importante tener en cuenta que en Bolivia existen sistemas generales de producción animal diferenciados por el tipo de vegetación, donde se crían los camélidos, por lo general en sistemas mixtos o incluyendo dos o más especies. Así, la región Oeste del Altiplano Central (que incluye las provincias de Pacajes y Sajama) presenta un sistema mixto que incluye alpacas, llamas y ovinos. La finalidad de este sistema es producir carne de llama y ovinos, y fibra de alpaca. La región de las pampas del Oeste y Centro del Altiplano Central se caracteriza por la ausencia de bofedales y alpacas. La producción principal de esta región es la carne de llama, que se comercializa a través de intermediarios. La región localizada entre las Provincia de Sur Lípez, Sur de la provincia Baldivieso y Nor Lípez entre 3.900 a 5.000 msnm se caracteriza por ser una región mixta de crianza de llamas, ovinos y caprinos (Vargas, 2005).

Es de destacar el amplio número de llamas muestreadas en el primero de los trabajos aquí resumidos, con un total de 394 animales analizados. Las muestras fueron recogidas de 24 localidades diferentes que se dividieron, para los análisis genéticos, en 12 grupos regionales. Comparando con otros estudios realizados en otros países de Sudamérica (Bustamante et al., 2002; 2006), nuestro trabajo representa la mayor colección de muestras de llamas analizadas para un estudio de diversidad genética. En el estudio de diversidad de alpacas bolivianas se consideraron 194 alpacas de ocho localidades

En términos de variabilidad genética, los 42 marcadores genotipados inicialmente en la población de llamas y los 22 microsatélites analizados en la población de alpacas mostraron 
altos niveles de diversidad genética. En la población de llamas todos fueron polimórficos con la excepción de los marcadores CMS25 y PCTD17 en determinados grupos regionales (Nor Lípez y Nor Cinti para CMS25, y Sud Lípez para PCTD17).

En el conjunto de la población de llamas estudiada se identificaron un total de 506 alelos diferentes, altos niveles de heterocigosis esperada y un alto número promedio de alelos por marcador (12.04). Los 12 grupos regionales en estudio mostraron valores altos de heterocigosis media esperada (rango He: 0.609, Sud Lípez - 0.673, Pacajes) y observada Ho (rango Ho: 0.585, Nor Lípez - 0.656, Quijarrro). El análisis de los 22 marcadores en la población de alpacas puso de manifiesto 258 alelos diferentes y, de forma similar a lo observado en las llamas, un alto número promedio de alelos por marcador (11.7). Para las ocho poblaciones estudiadas en este caso los valores medio de heterocigosis esperada y observada fueron ligeramente más elevados que en llamas (rango He: 0.664, Poopó - 0.743, Ulla-Ulla; rango Ho: 0.611, Poopó - 0.696, Turco).

Los resultados de diversidad genética descritos en la población de llamas analizada son comparables con aquéllos previamente presentados en el análisis de poblaciones de llamas en Argentina (Bustamante et al., 2002; Bustamante et al., 2006). Como hemos comentado anteriormente en relación a los datos de diversidad obtenidos en el análisis de alpacas bolivianas, y también cuando se compara con los resultados descritos en alpacas del Perú (Paredes et al., 2011) parece ser que la alpaca muestra un mayor nivel de diversidad genética que la observada en las llamas bolivianas. Esta comparación es de gran interés desde el punto de vista de la conservación de las dos especies de camélidos domésticas, especialmente en Bolivia, donde llamas y alpacas en determinadas zonas, se encuentran formando rebaños mixtos. Además, tal y como se comenta en los trabajos aquí presentados esta observación podría ser explicada por el alto porcentaje de hibridización descrito en la alpaca en base a los análisis de ADN mitocondrial, aunque sería necesario que estudios adicionales basados en marcadores genéticos nucleares confirmaran esta hipótesis.

La identificación de una mayor proporción, con respecto a los marcadores analizados en cada caso, de marcadores que mostraron una desviación significativa del equilibrio HW en la población de llamas que en la de alpacas podría explicarse por el hecho de que muchos de los 
marcadores habían sido descritos inicialmente en alpaca. Sin embargo, hay que señalar que se ha detectado una baja presencia de alelos nulos en llamas, con lo que la razón del desequilibrio HW en estas poblaciones se debería, probablemente, a efectos de endogamia dentro la población.

En cuanto a los niveles de consanguinidad observados en llamas, nos parece importante resaltar el signo positivo estimado para el parámetro $F_{\text {IS }}$ para el conjunto de la población estudiada, así como el déficit significativo de heterocigotos detectado en alguno de los grupos regionales estudiados, tales como Franz Tamayo, Ayopaya e Ingavi. En las alpacas estudiadas también se identificaron estimas positivas y significativas de este parámetro para siete de las ocho localidades muestreadas, con los valores de consanguinidad más altos identificados en las regiones de Lagunas, Ayopaya y Curahuara. En ambos casos, la explicación más razonable para justificar los niveles de consanguinidad identificados fueron las prácticas de manejo inapropiadas basadas en el uso de un número limitado de machos reproductores en una serie de localidades cercanas, en el caso de las llamas de las regiones del Altiplano boliviano Central y Norte, o el uso de machos reproductores dentro de los propios rebaños, en el caso de las tres regiones asociadas con los niveles más altos de consanguinidad en el estudio de las alpacas.

En cualquier caso, estos resultados en referencia a la consanguinidad de ciertas poblaciones de llamas y alpacas bolivianas destacan un problema que debe tenerse en cuenta ya que se sabe que niveles elevados de consanguinidad afectan a los valores fenotípicos de interés económico (Falconer \& Mackay, 1996), además de tener una directa asociación con la aparición de defectos genéticos recesivos, tales como malformaciones, o un descenso en la fertilidad tal y como se ha descrito en poblaciones de alpacas peruanas (Reyna, 2005).

La alta consanguinidad identificada en las poblaciones comentadas, tanto en llamas como en alpacas, contrasta con las estimas más bajas del parámetro FIS $_{\text {IS }}$ identificados en las poblaciones alpaqueras de Turco y Ulla Ulla. Parece ser que en ambos casos, son de nuevos las prácticas de manejo reproductivo las que explican estos resultados, por el considerable intercambio de machos reproductores que tiene lugar en la región de Turco, así como el uso en esa región de machos del Centro de Machaje Tika-Uta (Rodríguez \& Quispe, 2007), 
mientras que en el caso de Ulla-Ulla, una de las áreas más importantes de producción alpaquera, la continua introducción de machos mejorados provenientes de regiones de Perú (Iñiguez \& Alem, 1996) explicaría los reducidos niveles de consanguinidad detectados.

En cualquier caso, la información aportada por nuestros estudios en relación a los niveles de consanguinidad, debe tomarse en cuenta a la hora de poner en marcha cualquier tipo de programa de mejora genética o estrategia de conservación en poblaciones bolivianas de llamas o alpacas, sobre todo en cuanto afecten a los grupos regionales que han presentado niveles más preocupantes. Además, cabe señalar el valor que tendría la obtención de este tipo de información en poblaciones tanto de vicuñas como de guanacos consideradas en la actualidad como poblaciones amenazadas en proceso de recuperación y conservación ya que los efectos de la depresión por consanguinidad son de especial preocupación en este tipo de poblaciones.

La identificación de un importante número de alelos privados de grupo regional y con frecuencias media-alta en las poblaciones analizadas, ( $\mathrm{pA}=70$ y 50, en llamas y alpacas respectivamente), se relacionó hasta cierto punto con las poblaciones que mostraron la mayor diferenciación genética. Esto podría sugerir que las correspondientes poblaciones son pools genéticos distintos obtenidos por deriva genética o selección (artificial o natural). Aunque la falta, en la actualidad, de un mapa de ligamiento o de la secuencia del genoma de estas especies no nos permite realizar un juicio definitivo al respecto.

\section{OBJETIVO 2: Análisis de la estructura genética de poblaciones de llamas y alpacas} bolivianas usando microsatélites.

La baja diferenciación genética global $(F s t=0.014)$ identificada en la población de llamas, así como los bajos niveles de diferenciación identificada en los análisis pareados, indican una débil estructura genética, lo que en principio parecería extraño dadas el extenso rango geográfico y las diferencias altitudinales entre las poblaciones estudiadas aquí. No obstante, en este análisis ya se observó que los grupos regiones de Nor Lípez y Sud Lípez, ambos localizadas al sur del país, fueron las más diferenciadas entre sí (pair-wise Fst = 0.052) y con el resto de grupos regionales, mientras que las poblaciones del Altiplano Norte y Central mostraron un alto nivel de similitud genética demostrando en términos generales que 
las llamas muestreadas forman un conjunto homogéneo debido al continuo flujo de individuos entre los grupos regionales estudiados. Estas observaciones fueron apoyadas tanto por el análisis factorial de correspondencia, como por los resultados de los análisis AMOVA y SAMOVA, según los cuales únicamente el $1.5 \%$ de la variabilidad genética global se identificó entre los distintos grupos regionales estudiados.

Los resultados del análisis de asignamiento realizado con el programa STRUCTURE también pusieron de manifiesto una débil estructura genética en la población estudiada, y un importante flujo genético entre todas las localidades estudiadas. Los resultados iniciales obtenidos en este caso, sugiriendo un valor de $\mathrm{K}=5$ son el clásico ejemplo de la importancia que tiene la interpretación biológica de los resultados obtenidos en este tipo de análisis En este caso, las bajas proporciones de asignamiento de cada uno de los grupos regionales a los clusters inicialmente sugeridos por el análisis sirvieron para descartar el resultado inicial. Únicamente el grupo de Sud Lípez se podría asociar con un cluster específico, apoyando el cierto grado de diferenciación genética sugerido por los análisis anteriores para este grupo regional y que podría explicarse probablemente por el aislamiento geográfico de este grupo regional debido a las precarias condiciones de transporte y comunicación que presenta, determinadas por su situación geográfica extrema. Curiosamente, el método de análisis BAPS fue más concluyente desde un principio, ya que el análisis espacial realizado en este caso mostró que la mejor partición fue aquella identificada para un único cluster englobando los 12 grupos regionales estudiados.

Estos resultados contrastan con la clara estructura genética identificada en la población de alpacas de Bolivia analizada también en esta memoria. La diferenciación genética entre los grupos regionales de alpacas estudiada fue de baja a moderada con la Fst pareada más alta identificada para los pares Poopó-Ayopaya y Poopó-Ulla Ulla (pair-wise Fst $=0.077$ ). En este caso el análisis de AMOVA indicó que la variabilidad total observada entre diferentes poblaciones fue de $3.86 \%$, considerablemente más alta que el valor del $1.5 \%$ estimado en el caso de las llamas. La correspondencia identificada entre la clasificación productiva de las poblaciones estudiadas y su diferenciación genética (pair-wise Fst) es interesante, y pone de manifiesto que la cría de alpacas en Bolivia se está haciendo con intercambio de machos dentro de las regiones incluidas en cada uno de los sistemas alpaqueros predeterminados 
(FAO, 2005), Pacajes-Sajama, en el Altiplano Central, el sistema representado por LagunasCosapa-Curahuara y Ulla-Ulla, mientras que Poopó, población no asociada con ninguno de los sistema de manejos establecidos (FAO, 2005), resultó ser el grupo regional más diferenciado en base al menor flujo genético mostrado con el resto de grupos regionales,.

El análisis de estructura poblacional para las alpacas sostiene que las ocho poblaciones estudiadas pueden ser asignadas a por lo menos cinco clusters claramente diferenciados, entre los cuales Poopó es la población más diferenciada. En concordancia con estos resultados el análisis factorial de correspondencia sugirió un aislamiento genético de la población de Poopó y la influencia de la población de Turco sobre las poblaciones vinculadas al sistema alpaquero de Cochabamba y Pacajes-Sajama. La población de Ulla Ulla mostró una clara subdivisión que impactó sobre el resto de las poblaciones. Cosapa, Lagunas y Curahuara mostraron un background genético común, mientras que los dos clusters asociados al sistema alpaquero tradicional de Ulla Ulla mostraron una clara influencia sobre el grupo regional de Challapata y en menor medida sobre el de Ayopaya, mostrando ésta última la influencia de los cinco clusters identificados en el análisis. Nuestro análisis de estructura poblacional con STRUCTURE también puso de manifiesto la diferenciación genética del grupo regional de Turco, el cual parece tener, en base al uso de machos de esta región, una importante influencia sobre los correspondientes grupos regionales de Ayopaya, Cosapa, Lagunas y Curahuara (Rodríguez \& Quispe, 2007). A pesar de algunas limitaciones en el muestreo y la necesidad de confirmar los resultados descritos aquí con un mayor set de datos, este estudio proporciona la primera valoración sobre la diversidad genética en poblaciones de alpacas en Bolivia, pudiendo ser de gran valor para el desarrollo, en estas poblaciones, de estrategias de cría y manejo apropiadas.

La diferencia observada entre la estructura genética de las llamas y alpacas bolivianas se debe muy probablemente a las diferentes prácticas de manejo utilizadas en Bolivia para estas dos especies domésticas. Las llamas bolivianas son usadas primariamente para la producción de carne, principalmente para la subsistencia, y secundariamente para la producción de fibra (Iñiguez et al., 1998; Markemann et al., 2009). A diferencia de la cría de alpacas en Bolivia, que está más estructurada, las llamas son criadas por criadores locales sin seguir un programa específico de mejora (Wurzinger et al., 2008) y su cría implica un intercambio intensivo de 
machos reproductores entre localidades geográficamente cercanas, mientras que la cría de alpacas en Bolivia parece estar bien establecida alrededor de las regiones de mayor importancia alpaquera. El intercambio de machos reproductores en alpacas parece limitado entre estos sistemas diferenciados de manejo, mientras que en el caso de las llamas, parece que el intercambio de animales es extenso, entre todos los grupos regionales, y únicamente estaría limitado por el aislamiento geográfico y la falta de infraestructuras de comunicación apropiada. Estos factores parecen ser la explicación a la cierta diferenciación sugerida por los análisis presentados en esta memoria de Tesis para las poblaciones de llamas del sur del país, Sud Lípez y Nor Lípez. Ambas son comunidades de áreas remotas rodeadas por áreas geográficas extremas y que presentan problemas en infraestructura de comunicación.

En el análisis de las llamas bolivianas no se vio una estructura genética asociada con los principales tipos de variedades reconocidos para esta especia, T’hampulli, K'ara e Intermedia lo que parece sugerir que los marcadores estudiados son neutrales en relación a las características fenotípicas en las que se basa el asignamiento a una u otra variedad, principalmente relacionadas con el diámetro de la fibra y largo de mecha. De todas maneras la información derivada de nuestro estudio sugiere que las llamas de los grupos regionales más diferenciados, Sud Lípez y Nor Lípez, mayoritariamente pertenecientes a las variedades más valoradas por la calidad de su fibra, T’hampulli e Intermedia podrían ser utilizadas como recurso genético para la mejora de las características de producción de fibra en las llamas bolivianas (Iñiguez et al., 1998).

La falta de estructuración genética en llamas bolivianas debido a un intenso intercambio de reproductores entre las zonas productivas, así como la identificación de una débil diferenciación de algunos grupos regionales pone de manifiesto la necesidad en este país, de iniciar programas de mejora, de diversificación y especialización de los diferentes grupos regionales o variedades en función del tipo de producción para el cual sean más rentables, fibra o carne. Estos programas deben desarrollar asimismo políticas de conservación de la diversidad genética lo cual será de gran valor en el futuro a la vez que se debiera mantener y plantear un programa de explotación de los pools genéticos identificados como el caso de las llamas en la región Sur del país. 
Hay que tener en cuenta, sin embargo, los grandes avances que se están produciendo en los últimos años en el campo de la genómica en las especies ganaderas, y lo que avances similares pueden suponer en el estudio genético de los camélidos sudamericanos. De hecho, ya existe un proyecto de secuenciación de la alpaca (Vicugna pacos), uno de los 24 mamíferos secuenciados como parte del Proyecto de los Genomas de Mamíferos, financiado por el National Institutes of Health (NIH). En este proyecto global, se seleccionaron un grupo de especies para maximizar la diversidad de la rama del árbol evolutivo que representa a los mamíferos. A pesar de la baja cobertura (2.51X assembly) de la secuencia del genoma de la alpaca disponible a día de hoy en la base de datos pública ensembl (http://www.ensembl.org/Vicugna_pacos/Info/Index ) su disponibilidad y futuro progreso abren nuevos horizontes a la posible aplicación de la biotecnología en la mejora de los camélidos sudamericanos. Es de esperar que los avances de la genómica, y el desarrollo en las especies de camélidos sudamericanos de herramientas genómicas como las que ya se utilizan de forma rutinaria en otras especies domésticas, puedan utilizarse en un futuro relativamente cercano también en beneficio de los criadores de camélidos ofreciendo a las regiones andinas nuevas posibilidades de progreso y competitividad.

\section{OBJETIVO 3: Análisis del ADN mitocondrial en poblaciones de llama, alpaca y} vicuña en Bolivia: una contribución a la filogenia de los camélidos sudamericanos

Por su alta tasa de evolución, la ausencia de recombinación, y el tipo de herencia materna que presenta, el ADNmt permite que los polimorfismos ocurridos miles de años atrás se presenten todavía en altas frecuencias y en un alto número de copias. El ADNmt se ha constituido en una importante herramienta molecular para revelar la historia evolutiva de linajes matrilineales y brindar datos sobre eventos históricos que han formado la estructura genética de las distintas especies. En base a su estudio, también se pueden mostrar las relaciones de filogenia desde un punto de vista geográfico, así como procesos de domesticación. El análisis de este material genético ha sido valioso para obtener representaciones genético-moleculares de las distintas poblaciones humanas y animales del mundo, y también para el entendimiento de la historia evolutiva y las migraciones pasadas que han determinado la actual estructura genética de dichas poblaciones (Luikard, et al., 2001). 
De esta manera, en la presente Tesis Doctoral se planteó, de manera complementaria a los análisis realizados con marcadores nucleares, el estudio genético, mediante secuenciación del ADNmt, de las poblaciones de camélidos sudamericanos existentes en Bolivia, incluyendo especies domésticas y salvajes. De forma similar a los estudios nucleares, un primer objetivo de los análisis de ADNmt se centró en la valoración de la diversidad genética a nivel mitocondrial de estas poblaciones. Un segundo objetivo fue, dada la informatividad de los estudios mitocondriales a nivel evolutivo, el de hacer una aportación al conocimiento sobre las relaciones evolutivas entre camélidos de Bolivia y otras poblaciones de camélidos sudamericanos y aportar en la medida de lo posible información que ayude a entender el proceso de domesticación de llamas y alpacas a partir de sus especies antecesoras, guanacos y vicuñas.

La existencia simultánea de una especie doméstica y de su ancestro evolutivo no extinto, es una peculiaridad de los camélidos sudamericanos de gran interés ya que nos proporciona la oportunidad de estudiar in situ de una manera detallada y precisa los procesos de domesticación que determinaron el establecimiento de las nuevas especies domésticas. Por ello, a pesar de las dificultades para muestrear guanacos en Bolivia se consideró de gran importancia la inclusión de especímenes de esta especie en el estudio planteado, aunque dichas muestras procedieran de otro país sudamericano, en nuestro caso de Chile.

Los altos niveles de variabilidad genética detectada en este estudio de ADNmt, mediante el análisis del gen Cyt-b y la región hipervariable D-loop, fueron más elevados en las especies domésticas que en las salvajes. Estos resultados apoyan los resultados antes descritos en relación a los marcadores nucleares para las especies domésticas, en el sentido de que la variabilidad genética de llamas y alpacas parece elevada tanto a nivel nuclear como mitocondrial, y al mismo tiempo evidencian la existencia de severos cuellos de botella afectando la diversidad genética a nivel mitocondrial de las especies salvajes tras la domesticación ya que habrían estado expuestas a actividades de caza sin ninguna protección hasta hace pocos años atrás.

En concreto es de destacar que de las cuatro especies analizadas, las vicuñas mostraron los niveles de variabilidad genética mitocondrial más bajos. En concreto las vicuñas 
muestreadas en este trabajo corresponden a la variedad norte ( $V . v$. mensalis), para la cual Sarno et al., (2004) ya había identificado una reducida variabilidad a nivel mitocondrial, aunque en un escaso número de animales. En base a estas observaciones, nos planteamos realizar un análisis complementario, presentado en el cuarto trabajo incluida en esta memoria, en un grupo mayor de especímenes $V$. v. mensalis. En concreto analizamos un total de 35 muestras, frente a las 27 incluidas en el estudio general de las cuatro especies.

En este estudio, se encontró mayores niveles de diversidad genética que los descritos en anteriores estudios sobre las mismas poblaciones (Sarno, et al., 2004). Sin embargo, la identificación de haplotipos dominantes con un pequeño número de pasos mutacionales entre los haplotipos menores en ambos marcadores y los análisis de cuellos de botella realizados, demostraron una reciente expansión demográfica de la subespecie en cuestión, lo que implica un aumento en el número de animales pero no necesariamente en los niveles de variabilidad genética. A este respecto nos gustaría destacar que para la otra variedad de vicuña ( $V$. $v$. vicugna), que también está bien representada en Bolivia, Marín et al. (2007b) identificaron niveles altos de diversidad genética a nivel mitocondrial, lo que podría ser de interés en la planificación de futuros programas de manejo y conservación de esta especie.

Así, como ya comentábamos antes serían interesante un análisis basado en marcadores nucleares para obtener una valoración global de la diversidad genética de estas valiosas especies salvajes y establecer, si es necesario, los correspondientes programas de manejo y conservación genética para ayudar a que estas especies aseguren niveles adecuados de variabilidad genética y evitar la depresión endogámica. Ese tipo de estudios a nivel nuclear también serán de interés con el objeto de confirmar la estructura genética identificada por el análisis de AMOVA presentado en el análisis de ADNmt (Fst global = 0.594), y la existencia de un alto nivel de hibridación a nivel mitocondrial entre las poblaciones de especies domésticas sugerido por ese análisis y apoyado de forma concluyente por el análisis filogenético realizado.

Nuestros análisis filogenéticos, que además de las secuencias muestreadas incluyeron un total de 236 secuencias adicionales de ADNmt disponibles en GenBank de las cuatro especies de camélidos sudamericanos, apoyó la existencia de dos clados monofiléticos, G y V, 
claramente diferenciados y correspondientes a guanacos y vicuñas de forma separada. La presencia de las especies domésticas en ambos clados, y por tanto la existencia de un alto nivel de hibridación en estas especies sobre todo en la alpaca ya había sido anteriormente descrita por otros autores (Stanley et al., 1994, Kadwell, et al., 2001), aunque parece ser que las alpacas bolivianas presentan uno de los mayores niveles de introgresión del clado G, comparando con los resultados descritos en otras poblaciones de alpacas (Marín et al., 2007b).

Los análisis incluidos en esta memoria también apoyan la existencia, ya reconocida por otros autores, dentro de cada uno de los clados principales, de dos subclados diferenciados. En el clado G el análisis de las secuencias del Cyt-b claramente diferenció entre un grupo representado por los guanacos del norte (L. g. cacsilensis) y otro incluyendo a las formas del sur de esta especie (L. g. huanacus, L. g. guanicoe and L. g. voglii). Esta diferenciación aunque no tan evidente también fue sugerida por el análisis de la región D-loop. En lo relativo al clado $\mathrm{V}$, los dos tipos de secuencias pusieron de manifiesto la división entre vicuñas del norte ( $V$. v. mensalis) y del sur ( $V$. v. vicugna).

Aunque nuestros resultados claramente apoyan el modelo evolutivo en el cual el guanaco es antecesor de la llama, encontramos algunas llamas en el clado V (9 \% para Cyt-b y 8 \% para el D-loop), lo que sugiere que en algún momento del pasado se ha producido una introgresión de ADNmt de tipo V en las poblaciones de llamas bolivianas. Por otro lado, el gran número de alpacas identificadas en el clado G (63 \% para Cyt-b y 51 \% para D-loop) indicarían que, aunque esta especie proviene inicialmente de la vicuña, en base a los haplotipos exclusivamente compartidos entre vicuñas y alpacas, existe un nivel de hibridización muy alta en las alpacas de Bolivia, incluso mayor al descrito anteriormente por otros autores en relación a otras poblaciones de alpacas (Stanley et al., 1994; Kadwell et al., 2001).

Estos resultados, sin embargo, no fueron concluyentes a favor de una u otra teoría sobre el origen evolutivo de la alpaca: (i) origen mixto, Guanaco x Vicuña, o alternativamente (ii) existencia de un alto nivel de hibridación ocurrido durante o después de la domesticación (Stanley et al., 1994; Kadwell et al., 2001). Por otra parte, hay que tener en cuenta que los 
resultados de los análisis de la región de D-loop indicaron que los haplotipos G compartidos entre guanacos y alpacas también existen en llamas (81 \% de las especies domésticas), lo que parece indicar que los cruces entre las formas domésticas son frecuentes, pero que además podría sugerir que el origen de la alpaca se deba al cruce de vicuñas capturadas con el animal doméstico disponible en el momento, la llama (Hemmer, 1990). Estar teoría sería apoyada por el estudio de patrones de comportamiento en camélidos que demostraron que la vicuña puede haber presentado una mayor dificultad para su domesticación que el guanaco debido a su temperamento (González, 2002).

De todas maneras, sería interesante poder explicar las diferencias en cuanto al nivel de hibridación observado entre distintas poblaciones de alpacas de Sudamérica, por ejemplo los niveles moderados de hibridación descritos en alpacas de Perú analizadas por Marín et al. (2007b) frente a los altos niveles señalados por otros estudios (Stanley et al., 1994; Kadwell et al., 2001) incluyendo el trabajo aquí presentado. Nuestra hipótesis inicial para explicar estas observaciones fue que los niveles de hibridación podrían estar influidos por la distribución geográfica de las especies involucradas en los eventos de hibridación. Así se explicaría fácilmente los altos niveles identificados en alpacas de Bolivia, donde existe un gran número de llamas, en comparación con las de otros países donde el presencia de llamas es menor, como Chile y Perú (Marín et al., 2007b). Sin embargo, en contra de esta hipótesis, los resultados de nuestro estudio mostraron una falta de correspondencia entre los niveles de hibridación de las alpacas de Bolivia de diferentes regiones analizadas en el presente trabajo y la densidad de llamas correspondiente a esas regiones.

Otro de los resultados más importantes de este estudio fue la identificación, en base a las secuencias de la región de D-loop, de dos ramas intermedias entre los dos clados principales G y V, y que sugieren la existencia de dos posibles líneas matrilineales no descritas con anterioridad. Esta observación pone de manifiesto, con respecto el proceso de domesticación de llamas y alpacas, un mayor grado de complejidad que el inicialmente aceptado tal y como se ha desvelado para otras especies domésticas (Joshi et al., 2004, Meadows et al., 2007, Murray et al., 2010). 
Del mismo modo, la identificación de haplotipos compartidos entre llamas con las formas de guanacos tanto del sur como del norte, en base a ambos marcadores mitocondriales, se desvía de la hipótesis previamente propuesta de que las llamas se originaron únicamente a partir las poblaciones de guanaco del norte (L.g. cacsilensis) en los Andes centrales de Perú (Wheeler, 1995; Palma et al., 2001). Se sabe que hace 1.400 años la crianza de llamas estaba establecida en la costa del Perú (Shimada \& Shimada, 1985, Wheeler, 1995) y Ecuador (Wing 1986), desde donde han podido expandirse hasta llegar al norte argentino, chileno y permanecer mejor adaptadas en lo que hoy corresponde al territorio boliviano, lo que explica la alta diversidad genética encontrada con marcadores mitocondriales y nucleares. Así, nuestros resultados sugieren que algunas de las poblaciones de llamas de Bolivia pueden haber sido domesticadas a partir poblaciones matrilineales diferentes a las inicialmente sugeridas y que podrían incluir formas de guanaco del sur o, alternativamente, un ancestro salvaje hoy extinto. Esta hipótesis de múltiples centros de domesticación para llamas y alpacas es apoyada por evidencias zooarqueológicas (Yacobaccio, 2004; Mengoni Goñalons, 2008) y otros estudios genéticos a nivel mitocondrial (Marín et al., 2007b). La información presentada en esta memoria de Tesis Doctoral, en relación al posible rol del sur de Chile como un centro de domesticación de llamas podría ayudar a comprender de forma más completa el complejo y dinámico proceso de domesticación de los camélidos sudamericanos.

En conjunto, los análisis de ADNmt presentados en esta memoria pueden ayudar a valorar, de manera complementaria a los análisis nucleares, la diversidad genética de las poblaciones de camélidos sudamericanos, además de proporcionar una oportunidad para replantear las relaciones entre las actuales formas de camélidos domésticos y sus ancestros salvajes. Asimismo, en base a la alta diversidad identificada a nivel mitocondrial en las poblaciones de llamas bolivianas estudiadas, que mostraron haplotipos ancestrales comunes con guanacos actualmente distribuidos por Argentina, Chile, Bolivia y Perú, podemos considerar a la llama boliviana como un valioso pool genético relacionado con una muy amplia gama de formas antecesoras originarios de distintos puntos de la geografía de América del Sur. 

CONCLUSIONES 


\section{PRIMERA,}

El estudio del ADN nuclear en las poblaciones de llamas bolivianas mediante el análisis de marcadores microsatélite ha puesto de manifiesto una muy alta variabilidad genética en estos animales. Además, no se ha observado una estructura genética asociada a la existencia de diferentes razas, estirpes o grupos de cría. Esta situación podría derivarse de las prácticas comunes de manejo de los rebaños de llamas que se llevan a cabo en Bolivia, caracterizadas por un intenso intercambio de machos reproductores entre los criadores de localidades geográficamente cercanas. Tan sólo las llamas de Sud Lípez y Nor Lípez mostraron un moderado nivel de diferenciación genética, probablemente debido al aislamiento geográfico de estas poblaciones del sur del país, donde hay una carencia de infraestructuras de comunicación.

\section{SEGUNDA,}

El análisis de marcadores microsatélite llevado a cabo en la población de alpacas bolivianas ha identificado, también en esta especie, niveles altos de variabilidad genética. En este caso se ha puesto de manifiesto una clara estructura genética que identifica cinco clústers, o subpoblaciones claramente diferenciadas a nivel genético. Esta estructura genética parece deberse a que la cría de alpacas en Bolivia está más organizada y concentrada en las regiones de mayor importancia alpaquera, donde el intercambio de machos reproductores estaría limitado entre sistemas de manejo diferenciados.

\section{TERCERA,}

El análisis de ADNmt ha permitido confirmar las relaciones filogéneticas establecidas en estudios anteriores, con este marcador, utilizando camélidos de Perú, Argentina y Chile. Así hemos determinado en los camélidos bolivianos la existencia de los dos clados monofiléticos anteriormente descritos, uno representado por haplotipos nativos del guanaco (G) y otro representado por haplotipos originales de vicuña (V). Nuestros análisis, además, han puesto de manifiesto la existencia de dos nuevas líneas matrilineales, diferentes a las descritas y únicamente presentes en poblaciones bolivianas. Estos resultados ponen de manifiesto que el proceso de domesticación de llamas y alpacas no ha ocurrido en una única población de 
camélidos salvajes, ni en una sola localización geográfica, sino que presenta un mayor grado de complejidad que el inicialmente descrito.

\section{CUARTA,}

El análisis del ADNmt de llamas y alpacas bolivianas ha puesto de manifiesto un alto nivel de hibridación bidireccional en ambas especies domésticas. Así, se ha detectado que aproximadamente el 60 \% de las alpacas analizadas presentan un origen en el clado G y hasta un $10 \%$ de llamas tienen un origen materno derivado de una domesticación del clado V. Estos niveles de hibridación son superiores a los descritos en los camélidos domésticos de otros países sudamericanos. 
BIBLIOGRAFÍA 
Álvarez-Romero, J. \& Medellín, R. A. 2005. Lama glama. Vertebrados superiores exóticos en México: diversidad, distribución y efectos potenciales. Instituto de Ecología, Universidad Nacional Autónoma de México. Bases de datos SNIB-CONABIO. Proyecto U020. México. D.F.

Alzérreca, H. 1982. Área de distribución y centros de protección de vicuñas en Bolivia. Comunicaciones de la vicuña. La Paz, 4: 13- 16.

Alzérreca, H. \& Genin, D. 1992. Los sistemas ganaderos de la zona andina boliviana: del concepto a una caracterización. La Paz: IBTA-ORSTOM, 37 pp.

Arzamendia, Y. \& Vilá, B.L. 2003. Estudios de comportamiento y organización social de vicuñas, en la RB Laguna de Pozuelos, Jujuy, Argentina, como línea de base para el manejo sostenible de la especie. III Congreso Mundial sobre Camélidos, Potosí, Bolivia, 15-18 de Octubre.

Arzamendia, Y. \& Vilá, B.L. 2006. Estudios etoecológicos de vicuñas en el marco de un plan de manejo sustentable: Cieneguillas, Jujuy. pp. 69-84. en: Investigación conservación y manejo de vicuñas. B. Vilá (Ed.) Proyecto MACS. Buenos Aires. Argentina.

Bonavia, D. 1996. Los camélidos sudamericanos: Una introducción a su estudio. IFEA. Lima. $560 \mathrm{p}$.

Bustamante, A., Zambelli, A., de Lamo, D., von Thungen, J. \& Vidal Rioja, L. 2002. Genetic variability of guanaco and llama populations in Argentina. Small Rumin. Res. 4, 101497.

Bustamante, A., Mate, M.L., Zambelli, A. \& Vidal-Rioja, L. 2003. Isolation and characterization of 10 polymorphic dinucleotide microsatellite markers for llama and guanaco. Mol. Ecol. Notes 3, 68-69.

Bustamante, A., Maté, M.L., Lamas, H.E., Giovambattista, G., Zambelli, A. \& Vidal, L.R. 2006. Análisis de diversidad genética en tres poblaciones de llamas (Lama glama) del noroeste argentino. Rev. Chil. Hist. Nat. 79, 175-187. 
Carpio, M. \& Solari, Z. 1982. Diámetro de la fibra en el vellón de la vicuña. Universidad Nacional Agraria La Molina. Lima. Informes de trabajos de investigación en vicuñas 1: 54-102.

Cuéllar, E. \& Fuentes, A. 2000. Censo aéreo de guanacos Lama guanicoe en el Chaco cruceño. Revista Boliviana de Ecología y Conservación Ambiental, 8: 83-90.

Cuéllar E., Jammes L., Castro, G. \& Segundo, J. 2002. Current status of the Guanaco Lama guanicoe voglii in the Bolivian Chaco. Technical Report 69. Proyecto Kaa-Iya, Santa Cruz, Bolivia.

DGB\&AP (Dirección General de Biodiversidad y Áreas Protegidas). 2007. Informe de gestión a la XXVI Reunión ordinaria comisión administrativa del convenio de la vicuña. República de Bolivia, C. Huallata (ed.) República de Bolivia 23 p.

Di Rocco, F., Posik, D.M., Ripoli. M.V., Díaz. S., Maté, M.L, Giovambattista, G. \& VidalRioja, L. 2011. South American camelid illegal traffic detection by means of molecular markers. Leg Med. 13: 289-292.

DNCB (Dirección Nacional de Conservación de la Biodiversidad) 1996. Censo Nacional de la vicuña en Bolivia. Informe publicado por el Ministerio de Desarrollo Sostenible y Medio Ambiente. La Paz. 55 p.

Donadio, E. \& Buskirk, S. W. 2006. Flight behaviour in guanacos and vicuñas in areas with and without poaching in western Argentina. Biol. Conserv. 127: 139-145.

Falconer, D.S. \& Mackay, T.F.C. 1996. Introduction to Quantitative Genetics, 4th ed. Longmans Green, Harlow, Essex, UK.

FAO (Food Agriculture Organization), 2005. Situación actual de los camélidos sudamericanos en Bolivia. http://www.cites.org/eng/cop/ 14/prop/E14-P08.pdf.

FAO-ICAR. 2004. Seminar on Camelids. ICAR Technical Series. Current Status of Genetic Resources. Recording and Production Systems in African, Asian and American 
Camelids. Editors: R. Cardellino, A. Rosati \& C. Mosconi. ICAR, Via G. Tomassetti 3, 1/A, 00161 Rome, Italy.

Flores, E. \& Miranda, C. 2003. Fauna amenazada de Bolivia. ¿Animales sin futuro? Ministerio de Desarrollo Sostenible, Proyecto de Fortalecimiento Institucional al MDS (BID 929), La Paz. 144 p.

Franklin, V.M. 1982. Biology, Ecology, and Relationship to Man of the South American Camelids. In: Mares MA, Genoways HH, eds. Mammalian Biolov in South America. Linesville, Pymatuning Laboratory of Ecology Special Publication 6, University of Pittsburgh, 457-489.

Franklin, W.L. 2011. Family Camelide (Camels). In Handbook of the Mammals of the World. Volume 2. Hoofed Mammals. Wilson, D.E. \& Mittermeier, R.A. (eds.). Lynx Edicions, Barcelona, Spain. 42 pp.

González, B. A., Palma, R. E., Zapata B. \& Marín J. C. 2006. Taxonomic and biogeographic status of guanaco Lama guanicoe (Artiodactyla, Camelidae). Mammal. Review 36: 157-178.

González, J. 2002. Etología de camélidos y arte rupestre de la subregión río Salado (norte de Chile, II Región). Estudios Atacameños 23: 23-33.

Hemmer, H. 1990. Domestication: The Decline of Environmental Appreciation, 2nd edn, pp. 217. Cambridge University Press, Cambridge, UK.

Hofmann, R.K., Ilte K.C. \& Rios M.A. 1983. El manejo de la vicuña. Eschborn - GTZ. Lima. 705 p.

INE (Instituto Nacional de Estadística), 2008. Datos estadísticos. INE, Bolivia, April 2008, http://www.ine.gov.bo.

INFOL (Instituto Nacional de Fomento Lanero) 1985. Memoria VI reunión Ordinaria de la Comisión Técnico Administradora del Convenio para la Conservación y Manejo de la vicuña. La Paz. 103 p. 
Iñiguez, L.C. \& Alem, R. 1996. Role of camelids as means of transportation and exchange in the Andean region of Bolivia. World Anim. Rev. 86: 12-21.

Iñiguez, L.C., Alem, R., Wauer, A. \& Mueller, J. 1998. Fleece types, fiber characteristics and production system of an outstanding llama population from southern Bolivia. Small Rumin. Res. 30: 57-65.

IUCN, 1996. Red List of Threatened Animals. IUCN, Gland.

Joshi, M., Rout, P., Mandal, A., Tyler-Smith, C., Singh, L. \& Thangaraj, K. 2004. Phylogeography and origin of indian domestic goats. Mol. Biol. and Evol. 21: 454462.

Kadwell, M., Fernández, M., Stanley, H.F., Baldi, R., Wheeler, J.C. \& Rosadio, R. 2001. Genetic analysis reveals the wild ancestors of the llama and alpaca. Proc. R. Soc. Lond. B 268: 2575-2584.

Krumbiegel I. 1944. Die neuveltlichen tylopoden. Zoologischer Anzeiger 145: 45-70.

Laker. J., Baldo. J., Arzamendia., Y. \& Yacobaccio, H. D. 2006. La vicuña en los Andes. pp. 37-51. en: Investigación conservación y manejo de vicuñas. B. Vilá (Ed.) Proyecto MACS. Buenos Aires. Argentina.

Lang, K.D., Wang, Y. \& Plante, Y. 1996. Fifteen polymorphic dinucleotide microsatellites in llamas and alpacas. Anim. Genet. 27: 293.

Lauvergne, J.J., Renieri, C., Frank, E., Hick, M. \& Antonini, M. 2006. Descripción y clasificación de los fenotipos de color de los camélidos domésticos sudamericanos. En: Renieri, C., E. Frank \& O. Toro (Eds). Camélidos Domésticos Sudamericanos: Investigaciones recientes. DESCO, DECAMA, INCA TOPS, FONDO EMPLEO, Lima Perú. 357 p.

Lichtenstein, G., Vilá, B. \& Funes, M. 2008. La importancia de diferenciar entre animales silvestres y domésticos: guanacos y vicuñas son fauna y no son ganado. Reflexiones 
acerca del Proyecto de Ley expediente 1406-D-2008. Accesible en http://www.camelidosgecs.com.ar/pdf/GECS_Vicam_WCS.pdf

Llobet, A., Orozco, A. \& Velasco, A. 2003. Conservación y manejo de la vicuña en Bolivia. p. 157-164 en: Uso pastoril en humedales altoandinos. Taller es de capacitación para el manejo integrado de humedales altoandinos de Argentina, Bolivia, Chile y perú. O. Rocha (eds.). Convenio RAMSAR, WCS/Bolivia, La Paz. Bolivia.

Luikart, G., Gielly, L., Excoffier, L., Vigne, J. D., Bouvet, J. \& Taberlet, P. 2001. Multiple maternal origins and weak phylogeographic structure in domestic goats. Proc. Natl. Acad. Sci. 98: 5927-5932.

MACA (Ministerio de Asuntos Campesinos y Agropecuarios). 2003. Políticas de Desarrollo en Camélidos, Dirección de Ganadería, La Paz, Bolivia.

MACA (Ministerio de Asuntos Campesinos y Agropecuarios). 2004. Situación de los recursos zootécnicos en Bolivia, Dirección de Ganadería, La Paz, Bolivia.

Marín, J.C., Casey, C.S. \& Kadwell, M. 2007a. Mitochondrial phylogeography and demographic history of the vicuña: implications for conservation. Heredity 99: 70-80.

Marín, J.C., Zapata, B. \& González, B.A. 2007b. Sistemática, taxonomía y domesticación de alpacas y llamas: nueva evidencia cromosómica y molecular. Rev. Chil. Hist. Nat. 80: $121-140$.

Marín, J.C., Spotorno, A.E., González, B.A., Bonacic, C., Wheeler, J.C., Casey, C.S., Bruford, M.W., Palma, R.E. \& Poulin, E. 2008. Mitochondrial DNA variation and systematics of the guanaco (Lama guanicoe, Artiodactyla: Camelidae). J. Mammal. 89: 269-281.

Marín, J.C., Saucedo, C.E., Corti, P. \& González, B.A. 2009. Application of DNA forensic techniques for identifying poached guanacos (Lama guanicoe) in Chilean Patagonia. J Forensic Sci. 54:1073-1076. 
Markemann, A., Stemmer, A., Siegmund-Schultze, M., Piepho, H.P. \& Valle Zárate, A. 2009. Stated preferences of llama keeping functions in Bolivia. Livest Sci. 124: 119125.

Maté, M.L., Di Rocco, F., Zambelli, A. \& Vidal-Rioja, L. 2004. Mitocondrial DNA structure and organization of the control region of South American Camelids. Mol. Ecol. Notes 4: 765-767.

Maté, M.L., Bustamante, A.V., Giovambattista, G., Delamo, D., Lamas, H., Thungen Von, J., Zambelli, A. \& Vidal-Rioja, L. 2005. Genetic diversity and differentiation of guanaco populations from Argentina inferred from microsatellite data. Anim. Genet. 36: 316321.

Meadows J., Cemal I., Karaca O., Gootwine E. \& Kijas J. 2007. Five ovine mitochondrial Lineages identified from sheep breeds of the near east. Genetics 3: 1371-1379.

Mengoni Goñalons, G.L. 2008. Camelids in ancient Andean societies: A review of the zooarchaeological evidence. Quarter. Internat. 185: 59-68.

Molina, G.I. 1782. Saggio Sulla Storia Naturale del Chili. Tomasso d’Aquino, Bologna, Italy.

Müller, P.L.S. 1776. Natursystem. Supplements und Register-Band. Nurnberg.

Munyard, K.A., Ledger, J.M., Lee, C.Y., Babra, C.D. \& Groth, M. 2009. Characterization and multiplex genotyping of alpaca tetranucleotide microsatellite markers. Small Rumin. Res., doi:10.1016/j.smallrumres.2009.07.012.

Murray, C., Huerta-Sanchez, E., Casey, F. \& Bradley, D.G. 2010. Cattle demographic history modeled from autosomal sequence variation. Philos. Trans. R. Soc. Lond. B Biol. Sci. 365: 2531-2539.

Norabuena, M.C. \& Paredes, M. 2003. Variabilidad genética en dos poblaciones de Vicugna vicugna (Camelidae) del norte de Chile. Rev. Chil. Hist. Nat. 76: 99-104. 
Obreque, V., Mancilla, R., Garcia-Huidobro, J., Cothran, E.G. \& Hinrichsen, P. 1999. Thirteen new dinucleotide microsatellites in Alpaca. Anim. Genet. 30, 397-398.

Palma, R.E., Marín, J.C., Spotorno, A.E. \& Galaz, J.L. 2001. Phylogenetic relationships among South American subspecies of camelids based on sequences of cytochrome-b mitochondrial genes. In: Progress in South American Camelids Research (Ed. by M.G.A. Raunelli). Publication 105, pp. 44-52. EEAP, Gottingen.

Paredes, M., Machaca, J., Azor, P.J., Alonso-Moraga, A., Membrillo, A. \& Muñoz-Serrano, A. 2011. Genetic differentiation of six Peruvian alpaca populations. In: Fibre Production in South American Camelids and Other Fibre Animals. Wageningen Academic Publishers, pp. 161-166.

Penedo, M.C., Caetano, A. R. \& Cordova, K. I. 1998. Microsatellite markers for South American camelids. Anim. Genet. 29: 411-2.

Penedo, M.T.C., Caetano, A.R., Cordova, K. 1999a. Eight microsatellite markers for South American camelids. Anim. Genet. 30: 161-168.

Penedo, M.C.T., Caetano, A.R. \& Cordova, K.I. 1999b. Six microsatellite markers for South American camelids. Anim. Genet. 30: 399.

Pinaya, I. 1990. Informe inspección ocular proyecto de Decreto Supremo, creación Reserva Biológica Cordillera de Sama. DVSPN y C. CDF, M.A.C.A. Marzo de 1990.

Raggi, A. 1993. Características fisiológicas y productivas de los camélidos sudamericanos domésticos. Universidad Mayor de San Marcos de Chile. Actas II Simposio Internacional de Estudios Altiplánicos.

Rendón, O. H. 2000. Experiencia boliviana en el manejo comunal de la vicuña. p. 106-113 en: B. P. González, M. Ban, C. Tala \& A. Iriarte (eds.). Manejo Sustentable de la Vicuña y el Guanaco. Actas del Seminario Internacional. Pontificia Universidad Católica de Chile, Santiago de Chile. 
Renaudeau d'Arc, N. 2002. Community management of vicuña in the Bolivian Altiplano. Procedural Paper. School of Development Studies University of East Anglia, Norwich UK.

Reyna, J. 2005. Alpaca Breeding in Peru and Perspectives for the Peru. Centre for Advanced Technologies in Animal Genetics and Reproduction, Faculty of Veterinary Science, University of Sydney NSW, Alpacas Australia, Alpacas New Zealand, World Alpacas.

http://www.elitealpacabreedingsystems.com/library/AlpacaBreedingPeru.pdf.

Rodríguez, C.T. \& Quispe, J.L. 2007. Domesticated camelids, the main animal genetic resources of pastoral system in the region of Turco, Bolivia. In: Tempelman, K.A., Cardellino, R.A. (Eds.), People and Animals. FAO, Rome.

Sahley, C. T. 1999. Propiedad comunitaria y esquila en vivo de vicuñas en el Perú: evaluando la sostenibilidad biológica y económica. pp. 77-146. En: Tula G. Fang, Olga L. Montenegro, Richard E. Bodmer (eds.) Manejo y conservación de fauna silvestre en América Latina. La Paz, Bolivia. Instituto de Ecología.

Salinas, F. 1998. La continuidad genética de la llama (Lama glama) taxas de carne, color de fibra y ritos propiciatorios. Universidad Nacional Federico Villa Real. Lima-Perú.

San Martín, H. F. 1996. Nutrición de camélidos sudamericanos y su relación con la reproducción. Rev. Argent. Prod. Anim. 16: 305-312.

Sarno, R. J., David, V. A., Franklin, W. L., O’brien, S. J. \& Johnson, W. E. 2000. Development of microsatellite markers in the guanaco, Lama guanicoe: Utility for South American Camelids. Mol. Ecol. 9: 1922-1924.

Sarno, R.J., Franklin, W.L., O־ırien, S.J. \& Johnson, W.E. 2001. Patterns of mtDNA and microsatellite variation in an island and mainland population of guanacos in southern Chile. Anim. Conserv. 4: 93-101.

Sarno, R.J., Villalba, L., Bonacic, C., Gonzalez, B., Zapata, B., Mac Donald, D.W., O’Brien, S.J. \& Jonson, W.E. 2004. Phylogeography and subspecies assessment of vicuñas in 
Chile and Bolivia utilizing mtDNA and microsatellite markers: implications for vicuña conservation and management. Conserv. Genet. 5: 89-102.

SERNAP (Servicio Nacional de Áreas Protegidas). 2000. Áreas protegidas de Bolivia. CD interactivo. La Paz.

Shimada \& Shimada, 1985. Prehistoric llama verdin and herding on the North Coast of Peru. Society for American Archaeology 50: 3-26.

Skidmore, J., Billah, M., Binns M., Short, R. \& Allen, W. 1999. Hibridizing old and new world camelids: Camelus dromedaries x Lama guanicoe. Proc. R. Soc. Lond. B, 266: 649-656.

Stanley, H.F., Kadwell, M. \& Wheeler, J.C. 1994. Molecular evolution of the family Camelidae: a mitochondrial DNA study. Proc. R. Soc. Lond. B Biol. Sci. 256: 1-6.

Stemmer, A., Valle Zárate, A., Nürnberg, M., Delgado, J., Wurzinger M. \& Sölkner, J. 2005. La llama de Ayopaya: descripción de un recurso genético autóctono. Arch. Zoot. 54: 253-359.

Summar, K. 1993. Evolución y desarrollo de la ganadería camélida en el altiplano de Latinoamérica. Universidad Mayor de San Marcos Chile. Actas del II Simposio Internacional de Estudios Altiplánicos.

Thomas, 0. 1917. Preliminary Diagnosis of New Mammals Obtained by the Yale National Society Peruvian Expedition. Smith. Misc. Coll. 68.

Torres, H. 1992. South American Wild Camelids: An Action Plan for their Conservation. IUCN, Glandz.

Urquieta, B. 1993. Estrategias reproductivas de los camélidos sudamericanos en el Altiplano. Universidad Mayor de San Marcos, Chile. Actas del II Simposio Internacional de Estudios Altiplánicos. 
Vargas, T. 2005. Situación actual de los camélidos sudamericanos en Bolivia. Proyecto de Cooperación Técnica en Apoyo a la crianza y aprovechamiento de los Camélidos Sudamericanos en la Región Andina.

Vidal-Rioja, L., Zambelli A. \& Semorile, L. 1994. An Assessment of the relationships among species of Camelidae by satellite DNA comparisons. Hereditas 121: 283-290.

Webster, S. 1973. Native pastoralism in the South Andes. Ethnology, 12: 115-133.

Wheeler, J. 1984. On the Origin and early development of Camelide pastoralism in the Andes. In: Animals and Archaeology (Ed. by J. Clutton-Brock \& C. Grigson). BAR Internationel Series 202. Great Britain.

Wheeler, J. 1991. Los Camélidos Sudamericanos: origen, evolución y estatus actual. Avances y perspectivas del conocimiento de los camélidos sudamericanos. FAO: 11-48.

Wheeler, J.C. 1995. Evolution and present situation of the South American Camelidae. Biol. J. Linn. Soc. Lon. 54: 271-295.

Wheeler, J.C., Chikhi, L. \& Bruford, M.W. 2006. Genetic analysis of origins of domestic South American camelids. The domestication of South American camelids: a view from the South-Central Andes. In: Documenting Domestication: New Genetic and Archaeological Paradigms (Ed. by M.A. Zeder), pp. 229-341. University of California Press: Berkeley.

Wing, E.S. 1977. Animal Domestication in the Andes. In: Reed CA, ed. Origins of Agriculture. The Hague: Mouton, 837-859.

Wing, E.S. 1983. Domestication and use of animals in the Americas. In L. Peel \& P.E. Tribe (Eds) Domestication, conservation and use of animal resources. Elsevier, Amsterdam, 21-39 pp.

Wing, E.S. 1986. Domestication of Andean Mammals. In: Vulleumier F, Monasterio M, eds. High Altitude Biogeography. Oxford University Press, Oxford. 246-264 pp. 
Wurzinger, M., Delgado, J., Nurnberg, M.,Valle Zárate, A., Stemmer, A., Ugarte, G. \& Solkner, J. 2005. Growth curves and genetic parameters for growth traits in Bolivian llamas. Livest. Prod. Sci. 95: 73-81.

Wurzinger, M., Willam, A., Delgado, J., Nürnberg, M., Zárate, A.V., Stemmer, A., Ugarte, G. \& Sölkner, J. 2008. Design of a village breeding programme for a llama population in the High Andes of Bolivia. J. Anim. Breed. 125: 311-319.

Yacobaccio, H.D. 2003. Procesos de intensificación y de domesticación de camélidos en los andes centro sur. Memorias del Tercer Congreso Mundial de Camélidos, Potosí Bolivia. Tomo 1: 211-216.

Yacobaccio, H.D. 2004. Social dimensions of camelid domestication in the southern Andes. Anthropozoologica 39: 237-247. 